\title{
Imaginación Psico-Biológica de la nación: el uso político y disciplinar de la temporalidad en la construcción de la imagen psiquiátrica del indígena, la producción de objetos de saber psiquiátrico y la imaginería nacional en Quito- Ecuador de mediados del S XX
}

\section{MARLON FABRICIO HIDALGO MÉNDEZ}

Tesis para optar por el grado de Master en Historia y Memoria

Director Enrique Garguin, Universidad Nacional de La Plata Codirector Rafael Polo Bonilla, Universidad Central del Ecuador

La Plata, 23 de diciembre de 2018 


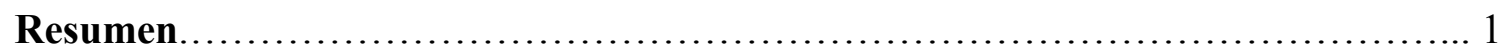

Agradecimientos....................................................... 2

Dedicatoria.............................................................. 3

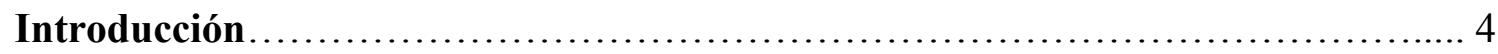

\section{CAPÍTULO I}

1.1 Descripción del problema $\ldots \ldots \ldots \ldots \ldots \ldots \ldots \ldots \ldots \ldots \ldots \ldots \ldots \ldots \ldots \ldots \ldots \ldots \ldots \ldots \ldots$

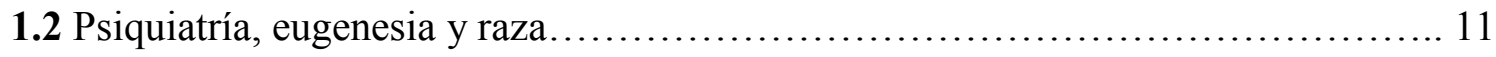

1.3 La higiene mental en el Ecuador a mediados del siglo XX.................... 13

1.4 La eugenesia en el Ecuador y los Archivos de Criminología en la Casa de la Cultura

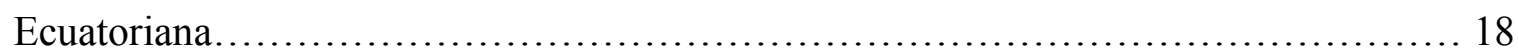

\section{CAPÍTULO II}

2. Metodología........................................................ 27

2.1 Modernidad y nación................................................. 27

2.2 Tiempo moderno, colonialidad y nación.................................. 28

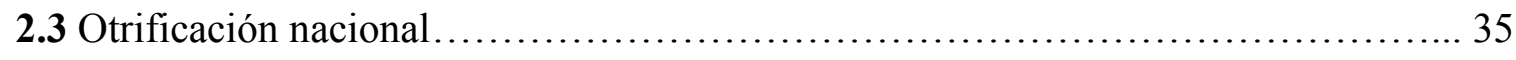

2.4 Nación, raza y utopía nacionalista....................................... 36

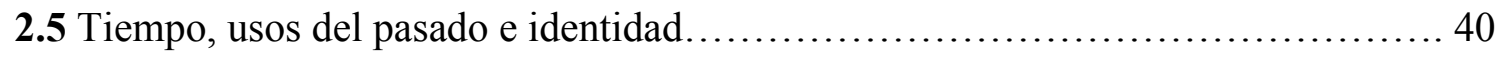

2.6 Instituciones del saber, campo de visibilidad y luchas por la representación........ 44

\section{CAPÍTULO III}


3.1 El evolucionismo, el ambiente, la biología, la raza, la nación y la historia: una comparación entre países.

3.2 La eugenesia positiva y negativa: una discusión del siglo XX sobre "ambiente" y "biología".... 63

3.3 Publicaciones extranjeras sobre eugenesia y psiquiatría en los Archivos de

Criminología.

\section{CAPÍTULO IV}

4.- De la producción psiquiátrica en Ecuador. 85

4.1 Descripción de los Archivos de Criminología Neuropsiquiatría y Disciplinas Conexas, Órgano del Instituto de Criminología en torno a su preocupación por la raza....... 85

4.2 Kretschmer, la biología y la historia: Teoría constitucional y el uso nativo del

Pasado

\section{CAPÍTULO V}

5.- La eugenesia en el campo de visibilidad psiquiátrico en el Ecuador. 107

5.1 El indígena y la nación ecuatoriana, breve contexto histórico 107

5.2 Temporalidad utópico-eugénica para la nación 116

5.3 Ciencia psiquiatría en Ecuador 118

5.4 Ciudadanía y raza. 120

5.5 El saber psiquiátrico y el "problema del indígena": psique, espacio, tiempo, raza y ventriloquía política psiquiátrica.

5.6 Presencia-presente indígena: entre lo atávico y lo patológico.

5.7 Presente atávico: lo incivilizado en tiempos de modernidad. 
5.8 El indio somato-psíquico

5.8.1 Del organismo al ambiente: un ambientalismo eugenésico indigenista psiquiátrico como oposición al indígena biológico-patológico-orgánico-anormal.

5.8.2 El criterio biotipológico del indio somato psíquico y la cronotopía

regulatoria

5.8.3 "Psicología del padecer" de la nación como concepción nativa del tiempo.... 141

5.8.4 El indígena mítico en los Archivos de Criminología: temporalización de lo normal y producción del pasado. 146

5.8.4.1 El ambiente y la patología como causa del retraso del indígena. 146

5.8.4.2 El pasado ancestral-ejemplar y el "resentimiento".

5.8.4.3 El indio somato psíquico/telos-normativo: la psicología de la historia como producción cronotópica del pasado.

5.8.4.3.1 Psicología de la raza india, biotipo, la "grandeza interrumpida" y el

Ambiente.

\section{CAPÍtULO VI}

6.- A manera de conclusiones. 157

BIBLIOGRAFÍA 164

FUENTES ESCRITAS. 


\section{Resumen}

Esta tesis repone una discusión que quedó plasmada en la primera revista especializada en psiquiatría en el Ecuador, los Archivos de Criminología, Neuropsiquiatría y Disciplinas Conexas, a mediados del siglo $\mathrm{XX}$, en la que un grupo de médicos y psiquiatras ecuatorianos en base a la Eugenesia, la Antropología Endócrina, la Biología, el Psicoanálisis entre otras corrientes científicas modernas que conforman el campo epistémico, producen una narrativa sobre la normalidad/anormalidad del indígena, la identidad psíquica-constitucional de la ecuatorianidad y el pasado/futuro/presente biológico de la nación. Ello permitió establecer una temporalidad política sobre el cuerpo y la psique del indígena con la cual se disputan sentidos sobre la historia, sobre lo moderno y se produce una forma de imaginería del Ser nacional a través de un esquema de visibilidad psico-biológico.

\section{Palabras clave}

Historia de la Psiquiatría, Indígena ecuatoriano, Psico-biología, Psicoanálisis, Eugenesia, Endocrinología, Nación, Ecuador, Usos políticos del tiempo, Temporalidad moderna. 


\section{Agradecimientos}

A Diana Bermeo por cederme un espacio en su casa durante un largo "verano" quiteño para escribir rodeado de una necesaria soledad y silencio. A la comunidad afectiva latinoamericana que me acogió en La Plata y Buenos Aires, por todo el cariño y la crítica sincera y académica a mí trabajo. A Erick Daccach por las horas interminables de escucha atenta a mis intereses académicos y a mis incontables inicios de conflictos emocionales. A Desheredadxs de la razón y Clandestinxs por la música, la convicción y la militancia en Romero. A Patricio Méndez por ser garante de mis sueños. A LATABLE (Paúl, David) por todas las chauchas salvavidas de este año. A las chirris, panas, carnales, parceros, guachines y yunta en general con la que compartimos bebidas, FA \#, alimento, ideas, viajes, esperanzas y mucha fiesta en La Plata. A la Yayita... ¿mi querida serendipia, bajo qué cielos y circunstancias vamos a bailar y festejar nuestra amistad la próxima vez?

Un agradecimiento muy especial y enfático a Cecilia Carvajal por cuidar con tanta dedicación y amor a Benjamín mientras yo escribía. Y a Rafael Polo y Enrique Garguin, asesores de este trabajo por valorar mis preguntas con paciencia y sobre todo con rigurosidad académica. Estoy seguro que sin su apoyo, confianza y sus críticas, el contenido de esta tesis no habría encontrado cause. 


\section{Dedicatoria}

A Lukas Benjamín, Radhaji, Margarita, Marcita, Daniel, Karla, Rafaela y a la EDUCACIÓN PÚBLICA.

"Somos como la paja de páramo que se arranca y vuelve a crecer... y de paja de páramo sembraremos el mundo." 


\section{Introducción}

Las investigaciones en el Ecuador han establecido varios inicios para el desarrollo de la Psiquiatría. Los esfuerzos de los psiquiatras por definir sus objetos de estudio, así como sus luchas por que el Estado reconozca la incidencia de su labor en el país y la necesidad de obtener un espacio adecuado para ejercer su práctica, han ocupado un lugar importante dentro de la investigación en torno a la historia de la Psiquiatría. Así por ejemplo, la fundación del Hospital Psiquiátrico moderno en los valles de la ciudad de Quito en 1953 y su indisoluble conexión con el antiguo Hospicio San Lázaro, que fuera uno de los primeros destinos comunes de los locos antes del arribo de la psiquiatría en la sierra ecuatoriana, ha permitido advertir de qué manera el objetivo común por la modernización de la práctica psiquiátrica estuvo ligado con el desarrollo epistémico de este campo.

Si bien desde inicios del siglo XX la construcción de un moderno Hospital une a los psiquiatras en torno a un objetivo, éste no fue el único proyecto ni el único logro que los convocaría en torno a la modernización de la práctica, o en torno a la conformación de su identidad, o a la delimitación de sus objetos de conocimiento o a la conformación de su campo estrictamente. Antes y después de la fundación del moderno Hospital, los psiquiatras participan de forma activa en la modernización misma del país.

Muestra de ello son las recomendaciones/advertencias/demandas que hacen al Estado ecuatoriano en distintos congresos sobre las políticas que deberían aplicar sobre la población para procurar su progreso. Las múltiples temáticas que abordan en las investigaciones publicadas en los Archivos de Criminología, Neuropsiquiatría y Disciplinas Conexas (la revista especializada en psiquiatría), permiten notar un esfuerzo por posar sobre estos múltiples objetos un discurso moderno y modernizante; la idea misma de publicar una revista especializada en psiquiatría da cuenta de ciertas estrategias y esfuerzos de una comunidad científica por la legitimación, circulación y difusión del saber que producen sobre esta variedad de objetos de los cuales se ocupan. También podemos notar la misma intención modernizante en la incidencia que tienen sobre la renovación del pensum académico en la Carrera de Medicina de la Universidad Central del Ecuador, así como las tesis de grado producidas en esta Facultad y dirigidas por médicos especializados en psiquiatría.

La inauguración del Instituto de Criminología, casi 20 años antes de la del Hospital, también es uno de aquellos logros. Más aún, es una clave para pensar cómo la psiquiatría a través de un discurso sobre el crimen, durante esas casi dos décadas, inscribe una amplia cantidad de tesis que sobrepasan una preocupación exclusiva sobre la patología mental. La labor de la psiquiatría, a la vez que impulsa procesos de modernización de las instituciones y de la vida cotidiana del país, propone nuevas maneras de hacer Historia, que en gran medida contendrían unas formas modernas de remembranza sobre los orígenes de la nación. 
La aproximación que hago aquí a estas huellas que dejó el pasado, me ha permitido reponer un litigio sobre la identidad nacional y sobre la normalidad/anormalidad del indio de la sierra ecuatoriana sostenido desde una narrativa psiquiátrica que se identifica a sí misma como moderna. En esta narrativa psiquiátrica se encuentra contenida una concepción sobre el tiempo elaborada a través de un uso particular de los postulados científicos provenientes de corrientes científicas modernas. Mediante esta concepción de tiempo y desde marcos epistémicos múltiples, los psiquiatras construyeron un discurso sobre la raza, ejercieron una labor intelectual para definir los objetivos de ciertas políticas de Estado, produjeron sentidos sobre el pasado nacional y disputaron un lugar como productores de historia.

Esta tesis despliega las indagaciones a esta huella del pasado en cinco capítulos:

En el primer capítulo se presenta el estado de la medicina en general y de la psiquiatría en particular en Ecuador. Ello en un contexto de reconfiguración de la nación en la que la concepción de lo moderno se anuda con la inteligibilidad psiquiátrica de la raza, el crimen, la patología mental. Este contexto a su vez es un escenario de disputa por la definición tanto de lo normal/anormal, como de la identidad nacional y de la emergencia del campo cultural junto a nuevas instituciones de Estado en las que la psiquiatría encuentra nuevos espacios, nuevas alianzas y nuevas disputas para su desarrollo, para la publicación de los postulados de sus investigaciones y los marcos epistémicos que los sostienen, y para la exposición de sus proyectos regionales y nacionales para encausar la modernidad, la política de Estado, la educación, la salud y el comportamiento por una vía adecuada (científica).

El segundo es un capítulo metodológico. En éste se presentan tres posturas que dialogan en torno a la pregunta sobre la narrativa que la psiquiatría produce sobre el indígena, la nación, la modernidad y la historia: la Historia Conceptual aporta elementos para pensar la producción de objetos de saber psiquiátrico, la disputa por la legitimidad del objeto, la producción de narrativas, la formación de saberes instituidos y la emergencia de instituciones del saber. La teoría poscolonial aporta con una crítica sobre los usos políticos del pasado, la construcción racializada y racializante de la alteridad y la imaginería de la nación en contextos poscoloniales como condición normalizadora de la integración y aglutinamiento de la nación. El campo de la memoria aporta a este diálogo la concepción del tiempo como categoría política y por tanto como elemento constitutivo de la construcción de la identidad inmersa en relaciones de poder-saber que, al delimitar fronteras entre el "otro", el "nosotros", el pasado y el presente, produce identidades desde una concepción nativa en base a la estructuración de temporalidades, la organización de la experiencia y la constitución del hecho histórico.

El tercero es un capítulo comparativo principalmente entre Ecuador, México, Argentina, Perú, Bolivia y Cuba. Se opta por la comparación como estrategia para encontrar similitudes y diferencias entre comunidades científicas, su permeabilidad, receptividad y 
rechazo a teorías en contextos nacionales distintos en donde se originan disputas por el sentido de lo social, la temporalidad de la nación y la raza. En este capítulo se puede encontrar que la Eugenesia, la Biología, el Higienismo, la Antropología Endócrina, el Darwinismo social, el Lamarckismo forman parte de un campo epistémico que se extiende por el continente produciendo narrativas distintas sobre la alteridad, la historia, la sociedad, la función del Estado, la identidad, el espacio nacional y la modernidad.

En el cuarto capítulo, se analizan los Archivos de Criminología Neuropsiquiatría y Disciplinas Conexas, a fin de captar la aprehensión de los objetos de saber en el campo conceptual psiquiátrico con los que se delimita un modelo de explicación de lo real en torno a la raza. La psico-biología aparece aquí como una narrativa sobre la raza, el presente, el pasado y el futuro de la nación. Narrativa compuesta por teorías modernas sobre el carácter, la constitución de un cuerpo endócrino/biológico/psíquico y usos nativos del tiempo para la constitución de lo social y nacional.

En el quinto capítulo se repone cómo el esquema de visibilidad psico-biológico que propone la psiquiatría, al objetivar la raza, produce una narrativa sobre la psique y la biología del indígena de la sierra ecuatoriana que monta sobre el cuerpo biológico y psíquico del indio una geopolítica del tiempo y una ventriloquía política con la que se construye tanto la identidad del otro atávico como la del nosotros moderno y actúa como una forma de imaginería de la nación.

En las conclusiones se retoman los principales hallazgos del trabajo para generar nuevas preguntas alrededor de lo expuesto. 
CAPÍTULO 1 


\subsection{Descripción del problema}

La nación ha sido objeto de diversas reflexiones provenientes de las más variadas disciplinas. No solo ha sido objeto de análisis críticos sociológicos, historiográficos, antropológicos, etc., también ha sido y es un objeto de disputa, una disputa por los elementos simbólicos que aglutinan a una población en torno a una "comunidad imaginada" (Anderson, 2008).

Este trabajo expone las huellas de la imaginación de la nación en un periodo de la Historia del Ecuador que se ha instalado en la memoria de varias generaciones del país con un dejo de vergüenza y que comúnmente se recuerda como "La guerra del 41". No es un trabajo que va, precisamente, tras el rastro de la disputa de la nación entre dos grupos contrapuestos en tal contexto histórico, sino que va tras una "forma particular de institución del relato nacional" (Polo, 2002) expresada en una narrativa psiquiátrica. La imaginación de esta forma psiquiátrica del relato nacional, entonces, la encontramos latente en la producción de objetos de saber psiquiátrico y en las regularidades que permiten hacer inteligibles a los objetos cuando una pregunta por la normalidad del indígena y por la nación acompaña dicha inteligibilidad.

Ello implica emprender ese rastreo con preguntas alrededor de los elementos teóricos y los eventos históricos, mitos o hitos que trabajan como conectores de la imaginería psiquiátrica de la nación tales como la raza, la salud mental, la psique, la higiene, la eugenesia, el psicoanálisis, la teoría constitucional, la biología, la producción de la temporalidad, el territorio, las costumbres, el lugar que se le otorga a la ciencia, las disputas disciplinarias. Preguntas que se desprenden de una lectura enfocada en la producción de trabajos científicos psiquiátricos hallados en un corpus documental en el que yace alrededor de 40 años de producción psiquiátrica. Este material fue hallado en el Museo Nacional de Medicina "Eduardo Estrella". Se trata de Los Archivos de Criminología Neuropsiquiatría y Disciplinas Conexas, Órgano del Instituto de Criminologíal.

Los Archivos de Criminología, según cuenta Landázuri (2008), son creados tras la fundación del Instituto de Criminología en 1936 en Quito. Es la revista que tiene como objetivo publicar y difundir el trabajo de la que fuera una de las primeras instituciones modernas científicas con que la psiquiatría cuenta para desarrollar y ejercer su profesión en torno a la realización de trabajos en Psiquiatría Forense.

Este no es un dato mínimo, solo tomemos en cuenta que recién en 1953 los psiquiatras ven inaugurado un Hospital Psiquiátrico moderno en el sector de Conocoto, ubicado en las periferias de Quito. Objetivo que persiguieron desde inicios de siglo. Antes debían ejercer sus funciones en el antiguo Hospicio-Manicomio San Lázaro, una edificación colonial

\footnotetext{
${ }^{1}$ En adelante se nombrara este documento como Archivos de Criminología.
} 
dispuesta en el centro de la capital ecuatoriana y que -como los propios psiquiatras la consideraban- era "inadecuada para la práctica moderna”. La edificación estaba a cargo de las Madres de la Caridad traídas por García Moreno durante su gobierno en el siglo XIX. Ello da cuenta que el desarrollo institucional de la criminología pudo avanzar más rápido que el desarrollo de la clínica asociado a las indagaciones sobre la locura. Al encontrarse conexa al Instituto de Criminología y no sólo al Hospital Psiquiátrico, los trabajos criminológicos publicados no se enfocan solo en la nosología, sino que se encuentran avocados a la etiología, al enfoque, que según Robert Castel (2009), atraviesa la práctica psiquiátrica desde finales del siglo XIX.

Esta revista es la única que se ha editado en materia psiquiátrica en el país, al menos hasta finales de los años 60s. Tras realizar una lectura de varios de sus números en un periodo de tiempo que va de mediados de los años 30 hasta inicios de los 70s, en la década del 50 y hasta mediados del 60 se encontró un grupo de trabajos escritos por médicos y psiquiatras ecuatorianos que, en inicio, buscaban dar una respuesta a la pregunta sobre la normalidad o anormalidad de los indígenas. Posteriormente la pregunta se convierte en una discusión sobre las causas de su retraso.

Para resolver la cuestión sobre las causas de lo que entienden por retraso del indígena ecuatoriano, se recurre a teorías que en la época gozan de reputación científica en Europa, E.E.U.U y América Latina. Por un lado se encuentran las teorías biológicas sobre la herencia como la formulada por Jean-Baptiste Lamarck y de estudio de la personalidad como las Tipologías corporales de Ernst Kretschmer. Por otro lado se hace uso del test de Hermann Rorschach. Un test proyectivo asociado al Psicoanálisis, una teoría, en principio, contrapuesta a los postulados biológicos que defienden la herencia como única forma de explicación de la configuración psíquica. Por ambas vías se llega a una conclusión similar que podría resumirse en los siguientes términos: el indígena es normal y su retraso se debe a que es inculto e incivilizado. Tras esta conclusión, las investigaciones buscan la etiología del retraso del indígena en otra variable.

En medio de dicho debate los médicos y psiquiatras componen y proponen una discusión implícita sobre la nación ecuatoriana, sobre sus orígenes, sobre su Ser. Para discutir sobre el ser nacional se remiten primero a una disertación teórica sobre la definición de la biotipología del indígena. La discusión sobre la nación, entonces, arranca en un trabajo que da cuenta de la normalidad/anormalidad del indígena dentro de los márgenes teórico de nociones eugenésicas. Los psiquiatras, en una discusión sobre lo normal y lo anormal que evoca a la eugenesia, sobre lo culto que aparece como lo civilizado y lo inculto que se delinea como lo retrasado, ponen en el centro a aquel sujeto cuya mitificación ha servido como hilo conductor de la imaginería de la nación ecuatoriana desde la Independencia a principios del siglo XIX: el indígena. 
También aparecen publicados en los Archivos de Criminología textos de autores extranjeros. Los textos dan cuenta de un debate sobre el concepto de eugenesia positiva. Este concepto, según Robles y Caballero (2016) fue formulado y defendido por los psiquiatras franquistas para contraponerse a la eugenesia negativa que desde el Régimen nazi promovió la esterilización de las razas inferiores.

En los estudios que los psiquiatras ecuatorianos hacen del indígena dentro de los márgenes de la eugenesia, la higiene, la biología y el psicoanálisis, la patología no explica su retraso, su condición de incivilizado sí. Tras revisar su psique y su Constitución y no encontrar indicios de una degeneración que explique su condición, el ambiente surge como la variable para explicar su retraso. Los psiquiatras ecuatorianos en su diagnóstico del estadio incivilizado del indígena, tras descartar la anormalidad -a la vez que redefinen la comprensión de lo normal-, apuestan por una aprehensión del indígena que se inclina por la línea de la eugenesia positiva. Este desplazamiento de la mirada médico-psiquiátrica ubica la atención en los efectos del ambiente sobre la psique y la biología y, genera nuevas certezas sobre las causas de la incivilización del indígena que derivan en una comprensión geo-temporal y racial sobre el retraso del indígena que involucra, a su vez, una forma de definición de la identidad moderna y una forma de imaginar la temporalidad de la nación moderna y sus otros.

En este desplazamiento de la mirada médico-psiquiátrica, la objetivación de la patología mental y de la anormalidad/normalidad ya no se liga solo a su recusa, encierro o medicalización, ahora comprende un propósito más amplio: la construcción objetivada del pasado que actúa como ruptura con un sujeto incivilizado. Por otro lado, define límites entre un "nosotros" que se ve a sí mismo encaminado en un proceso hacia la modernidad y un "otros" racializado/incivilizado al que debe corregir.

La presente investigación reconstruye una discusión eugenésica, psicoanalista, biológica e higienista sobre el indígena y la nación como una forma particular de institución del relato nacional y una forma articuladora de la identificación moderna. Identificación a su vez conexa con la producción del saber y con la oposición a un presente incivilizado que es montado desde la mirada de la disciplina médico psiquiátrica y vinculada, además, a la lectura psico-biológica de la nación.

Se da cuenta aquí de cómo la distancia y proximidad con el pasado-presente permite la articulación de un presente moderno y una identificación anclada a ese presente, así como la aprehensión de la nación y el indígena en una pretensión de tallarlos como objeto de saber psiquiátrico. Se aborda en este trabajo la producción de objetos de saber psiquiátrico partiendo desde las distancias que esta disciplina entabla con un pasado que construye permitiendo unas identidades y unos saberes y, desplazando otras. No se parte de la relación razón/locura, sino de la tensión de las temporalidades en la que entran en juego una valoración del pasado, del presente, la normalidad/anormalidad, el indígena y la nación 
para erigir un presente moderno desde una mirada higiénico-eugenésica en Quito-Ecuador de mediados del S XX.

\subsection{Psiquiatría, eugenesia y raza}

En su trabajo "El orden Psiquiátrico" Robert Castel (2009) considera que la edad de oro del alienismo se ve marcada por un re-direccionamiento del enfoque de la Psiquiatría. Este autor señala que a finales del siglo XIX los discursos y las prácticas psiquiátricas trasladan su atención de la nosología a la etiología. No quiere decir que la nosología fuese descartada o que pasara a segundo plano, lo que Castel plantea es que el enfoque etiológico suscitó y facilitó un énfasis en la prevención y en la supervisión del estado mental de las poblaciones y no solo en el tratamiento y la rehabilitación de individuos. Para Ricardo Campos y Enric Novella (2017) en este contexto la higiene mental pasa a ser la brújula reflexiva, "el ideario de referencia" (p.66), para que la disciplina adquiera un protagonismo social con nuevas estrategias y nuevos espacios de intervención que le permitan ubicar su mirada en toda la sociedad y ya no solo en el espacio del manicomio.

Antes de este giro, en 1857 Morel ya había desarrollado y consolidado una teoría sobre la degeneración y existe ya un análisis de la herencia en relación con ciertas patologías de espacie. Si bien la noción de degeneración de Morel es anterior a la publicación del Origen de las especies de Charles Darwin la preocupación por la herencia y la patología de especie es bastante generalizada, y para finales del siglo XIX, cuando la obra de Darwin está bastante difundida, ésta pasa a constituir uno de los pivotes para la construcción de una "visión negativa de la insania, en especial a través de los trabajos de los filósofos sociales ingleses Herbert Spencer y Samuel Butler, la escuela italiana de antropología criminal de Cesare Lombroso y de los alienistas franceses Victor Magnan y Benedict Morel." Además el evolucionismo entra en la psiquiatría clínica por su capacidad de explicar conductas y estructuras sociales, y para 1970 forma un modelo biopsicosocial (Balbo, 2002, p. 47).

Según Foucault (2010), ese binomio herencia-degeneración ${ }^{2}$ permitió la interpretación eugenésica o racista de la enfermedad mental y de la anomalía tras un anudamiento de la biología con el racismo de espacie. Es así que las postrimerías del siglo XIX ven aparecer la eugenesia como eje para la construcción de objetos psiquiátricos. Sumado al enfoque etiológico, esta aparición de una biología de tipo racista, que tiene como centro a la noción de degeneración, estaría implicada en el deslazamiento epistémico que trasladó a la mirada psiquiátrica de los confines del manicomio permitiendo que se ocupe de la sociedad,

\footnotetext{
${ }^{2}$ Según Edgardo Castro (2011) en realidad Foucault llega a dar cuenta a lo largo de su obra de un trinomio herencia-perversión-degeneración que constituyó el núcleo más sólido de las tecnologías del sexo. No me ocupo aquí de la perversión puesto que no abordaré la problemática de las tecnologías del sexo y la articulación de mecanismos disciplinarios y reguladores en torno al sexo la herencia y la degeneración. Por ello, hago referencia al primer binomio degeneración-herencia del que da cuanta en el curso dictado entre 1974-1975 en el Collège de France titulado "Los anormales" (2010).
} 
entendida ésta en términos de especie humana. El enfoque etiológico y eugenésico son parte de esos pasos que efectúan el traslado de la preocupación por el individuo a la preocupación por la psicología de masas.

De aquí que la degeneración y la herencia, según Foucault (2010) permitiesen detectar el peligro social, darle estatuto de enfermedad, construir, producir y definir lo anormal aislarlo y medicalizarlo. La eugenesia, este racismo de especie, que tiene como elemento teórico a la degeneración que incluye la noción de herencia y de anormalidad, constituye, para este autor, la clave de la extensión del poder psiquiátrico. Para que este racismo de especie calce y se adhiera con un racismo étnico, tuvo primero que conformarse como una forma coherente de saber psiquiátrico organizado como una teoría sobre la transmisión o herencia de anomalías. Antes de ser una ideología política fue una ideología científica que calzaría bastante bien en el advenimiento de los regímenes totalitarios del siglo XX. "Creo, entonces, que las nuevas formas de racismo que tienen influencia en Europa a finales del siglo XIX y principios del siglo XX deben referirse históricamente a la psiquiatría." (Foucault, 2010, p. 295).

La eugenesia, como teoría de la degeneración, traspasó por mucho los límites de la psiquiatría y pasó a ser una discusión teórico política que tendría una resolución local acorde al contexto histórico de cada país. Según sugiere José Robles y Vicente Caballero (2016), en las décadas de 1930, 1940 y 1950, la eugenesia ocupa un lugar destacado al interior de los regímenes políticos de occidente. Los psiquiatras, en distintos contextos temporales, sociales y políticos, desde un punto de vista eugenésico ayudan a reconstruir los orígenes raciales de las naciones. Para ello se redefine el sentido de la eugenesia en cada nación y acontece un debate dentro del nuevo marco de discusión de la etiología de la enfermedad y la anomalía instaurado desde finales del siglo XIX (Campos y Novella, 2016). El meollo del debate gira en torno a si el enfoque de la eugenesia debe centrarse en el genotipo o en el fenotipo.

La eugenesia como una teoría científica sobre la raza, de gran aceptación en Europa y las américas, no se difundió solamente como una teoría para la definición de la nosología y el esclarecimiento de la etiología de la degeneración, la eugenesia pasó a constituir una forma de narrativa acerca de los orígenes, trayectos y declives de las razas como es el caso de Italia y España (Robles y Caballero, 2016).

El cuerpo teórico de la eugenesia constituyó un instrumento político para construir verdades médicas vinculadas a la conducción del Estado (Vallejo y Miranda, 2005). En Argentina prevaleció una eugenesia que apostó por la corrección moral para evitar la degeneración, y se inclinó por una explicación de la sociedad desde los rasgos ambientales (Vallejo, 2016). La eugenesia también aportó elementos teóricos y científicos para la producción de alteridades en la reconstrucción de nación (Radcliffe y Westwood, 1999), constituyó estrategias de defensa y normativización social a través de prácticas institucionales 
concretas como las normativas sobre la sexualidad a través de Políticas Públicas profilácticas (Serrano, 2016) enfocadas en la prostitución y la construcción de habitus de higiene en Ecuador (Kingman, 2008).

También ayudó a hacer de la descendencia un problema de orden público en muchos de los países de Latinoamérica llegando a entender la educación de masas como un medio para la civilización y la mejora de la descendencia como una forma de "progreso genético" como en el caso peruano (Yzú Rossini, 2016); y en el caso de México, la eugenesia convirtió el progreso de la nación en un problema biológico, los eugenesistas mexicanos buscaron hacer del Estado el protector y garante de la selección natural biológica (Suárez y López Guazo, 2016). En Colombia la eugenesia inspiró proyectos políticos y raciales que buscaron promover la salud y la limpieza de las poblaciones negras de la costa, para eliminar, lo que se entendía como su contaminación biológica y cultural en pos de mejorar racialmente al Caribe (McGraw, 2007).

Como vemos, los debates sobre eugenesia encontraron en los intereses políticos de cada país una vía para la resolución de las discusiones acerca de la raza, la función del Estado, el rol de la ciencia en la sociedad y permitieron la asimilación del progreso como un concepto social, histórico, biológico y como un fin político. El énfasis en el genotipo o el fenotipo dependía en gran medida de los horizontes políticos de cada nacionalismo, ya sea para concebir al Estado como protector de una estadía permanente de una élite en los peldaños más altos de la escala social de clases a través de la tutela de la selección natural biológica como en México, o para el control estatal del azar en la selección natural como en Argentina, también permitieron biologizar la cultura para construir una identidad nacional como en el caso de Perú, o procuraron la conducción científica de las poblaciones incivilizadas hacia las vías de la modernidad como en el caso de Ecuador y Colombia ${ }^{3}$. Por ello, quizá el racismo y la eugenesia no solo permitieron la extensión del poder psiquiátrico, como dice Foucault, sino que en América Latina impulsaron la extensión del poder de la ciencia como una vía de construcción del Estado y la Nación y como forma de organización social.

\subsection{La higiene mental en el Ecuador a mediados del siglo XX}

El "Tercer Congreso Latino-Americano de Salud Mental” emite un Acta en noviembre de 1958 publicada en los Archivos de Criminología en que constan los objetivos y actividades políticas y profesionales de la Psiquiatría. Las políticas preventivas de Higiene mental se perfilan como el camino que la Asociación Latinoamericana Pro-Salud Mental, presidida por el reconocido Doctor y Psiquiatra peruano Honorio Delgado, sugiere seguir a los gobiernos para alcanzar un estado ideal de sociedad.

\footnotetext{
${ }^{3}$ Para mayor detalle de las formas políticas que adopta la eugenesia y la higiene en distintos países véase el capítulo tres (3).
} 
El programa social y científico que trazan las medidas preventivas de Higiene Mental de la Asociación Latinoamericana Pro-Salud Mental, de la que el ecuatoriano Dr. Julio Endara forma parte, ofrece un gran espectro de acción higiénico psiquiátrico profiláctico para los distintos Gobiernos y Estados del continente. El programa de acción sugiere recomendar a los Gobiernos y Estados lo siguiente:

-Intensificar los estudios epidemiológicos de morbilidad psiquiátrica en áreas urbanas y rurales para un conocimiento integral de la realidad en materia de patología mental para un desarrollo efectivo de los planes de Salud.

-Establecer el Servicio Psiquiátrico en todos los Hospitales Generales, Centros de Asistencia de Primeros Auxilios, Postas Sanitarias, instituciones educativas y, en general, en las entidades de carácter médico y social.

-Crear Servicios Móviles para la atención de los casos psiquiátricos en medios rurales o alejados de los centros de tratamiento especializado.

-Integrar, en los servicios que competan, a psiquiatras y técnicos especializados para prevenir los problemas de salud mental derivados de la migración externa.

-Adoptar medidas para la trasformación de los cultivos de caña de azúcar en las Zonas Andinas y Selváticas dedicadas a la producción de alcoholes, coordinar la legislación para la producción de alcohol de caña y bebidas alcohólicas en conformidad con los acuerdos internacionales y con las disposiciones de la Organización Mundial de la Salud. Advertir a través de Seminarios internacionales acerca de los problemas del consumo de alcohol y unificar criterios a partir de investigaciones científicas realizadas en todo el continente.

-Condenar la toxicomanía del cocaísmo en defensa de la Salud Mental de los indígenas en los países en los que se mastica coca habitualmente y condenar el comercio clandestino de cocaína; y recomendar la elevación de las condiciones socio-sanitarias de la colectividad indígena mediante la mejora de la alimentación, la vivienda y las condiciones generales de vida y trabajo, así como el establecimiento de centros educacionales con fines de tecnificación e industrialización de las labores agrícolas. También se recomienda remplazar el cultivo de coca por sembríos adecuados para la alimentación del indígena. Además, condenar todo uso de otras drogas como mescal, opuntia, ayahuasca, yage, maconha, cohoba, huillca, daturismo, etc. comunes en los indígenas. Finalmente, legislar para que los fármacos sean adquiridos y prescritos solo por profesionales médicos.

-Mejorar las condiciones del agro para elevar el nivel de vida y el desarrollo de planes de salud mental.

-Mejorar las condiciones de trabajo y acompañar la adecuada adaptación del hombre al trabajo. 
-Realizar exámenes psiquiátricos antes de otorgar licencias de conducción.

-Realizar consejos técnicos para la construcción de la vivienda popular para preparar a la colectividad orientándola dentro de su ambiente futuro.

-Integrar a todas las Ciencias Sociales a los Congresos Latino-Americanos de Salud Mental.

-Aplicar profilaxis positiva en lo referente a películas y dictar mediadas apropiadas para normar la industria cinematográfica en pos de usarla como garantía de la educación adecuada de la población.

-Poner en contacto a los Estado y Gobiernos con el Instituto Interamericano de Estadísticas para estudiar la factibilidad de realizar un Censo de Enfermos Mentales y Censos Psíquicos de la población en general con fines de una mejor profilaxis mental.

-Apoyar organizaciones juveniles como Grupos Scouts para brindar a los jóvenes una educación conveniente.

-Formar a los educadores en psiquiatría general e higiene mental.

-Enfocar en la familia el desarrollo normal de la personalidad a través de la procura de su adecuado funcionamiento y estructura. Al respecto, los Estados y Gobiernos deben reconocer que el niño está moldeado por la configuración psicosocial de la familia y por ello es de mucho valor para la salud mental de la colectividad y el individuo.

-Erradicar las causas sociales y económicas que contribuyen a la delincuencia. Por tanto, investigar científicamente el comportamiento criminal. Se debe por ello integrar en el sistema penitenciario el servicio de Psiquiatría y Psicología, Trabajo Social. Investigar la conducta antisocial del menor y revisar el Código de Menores.

-Investigar las causales de la prostitución y analizar su erradicación.

Criminalidad, prostitución, migración, educación, prevención de la toxicomanía, estadística de la salud mental de la población, familia y niños, cine y educación, convivencia y seguridad, epidemiología, el indígena y el mundo del agro, son las áreas a las que apunta la psiquiatría para el trabajo en conjunto con los Gobiernos y Estados por una defensa del bienestar social y dan muestra de una amplia cantidad de problemáticas que moviliza la higiene y en la que los hombres de ciencia se ven a sí mismos como solución.

En Ecuador varias de las resoluciones de la Asociación Latinoamericana Pro-Salud Mental ya han sido puestas en marcha y otras continúan como parte del programa. 
Genoveva Godoy Betancourt, jefa de Estadística e Identificación del Instituto de Criminología en Quito realiza un trabajo estadístico sobre "Formas predominantes de la criminalidad en Latino América". Las variables que considera son la predominancia por etnia y lugar geográfico del delito: provincia, cantón, región, ciudad. A través de este estudio, los profesionales de la psiquiatría criminológica, le ofrecen al Estado ecuatoriano información para elaborar política púbica alrededor de la predominancia de la criminalidad atendiendo al número de causas judiciales en relación a todo el país. Godoy advierte que lo que puede saber al respecto es limitado, pero ayuda a reconocer el problema de la densidad criminal geográficamente concentrada en la Provincia del Cañar y permite saber que entre los infractores predominan los de sexo masculino, estado civil casado, situación económica mala, de baja instrucción y de raza mestiza

lo que nos lleva a la conclusión de que el sexo masculino, casados, de cultura escasa, situación económica mala o mediocre, es más proclive al delito. De ahí que por lo menos el tratamiento carcelario deberá ser de reeducación del delincuente y habilitación para la vida de trabajo en libertad; pues hay fundamento para suponer que la cultura, el mejoramiento económico de los hogares, sobre todo en la clase media, reducirá el número de delincuentes. (Godoy, 1956, p.59)

Sabiendo esto, los Gobiernos además, deben promover la organización de Servicio Social no solo para los reclusos que recuperan la libertad, sino para estudiar el ambiente familiar de estas clases sociales sobre todo si tiene las características mencionadas (que estadísticamente se puede decir que es lo más común), puesto que este tipo de familias serían reproductoras de delincuencia. Por tanto, el Servicio social debe dirigirse a los reclusos mientras permanecen internos y debe actuar también sobre estos y sus familias cuando hayan sido liberado.

El estudio estadístico en general se perfila como una herramienta de suma importancia para la gobernanza y la organización social, pues, según el Instituto de Criminología le ofrece al país datos certeros sobre el delito y las acciones adecuadas para su prevención respondiendo a las diferentes problemáticas de tipo social, cultural o económica que se puedan presentar dependiendo de la influencia del factor étnico o geográfico.

Además de la estadística nacional sobre criminalidad y los estudios psiquiátricos y científicos sobre criminalidad para su prevención, los vicios sociales y el mundo del trabajo también son parte central de los objetos que la higiene mental busca aprehender.

El Dr. José Cruz Cueva (1954), Profesor titular de Medicina Legal de la Universidad Central del Ecuador, publica dos estudios centrados en el tema. Le preocupan el tabaquismo y el alcoholismo que estadísticamente muestran "lo arraigado que está el vicio en nuestra gente obrera” (p. 470). Además se le inquietan cómo los antecedentes familiares, el medio ambiente (de miseria económica, mal ejemplo y antihigiénico) y los antecedentes personales influyen en las adicciones, y cómo las adicciones influyen en el deterioro de la 
higiene mental al volver a los adictos y sus descendientes más propensos a desarrollar patologías mentales y orgánicas.

El trabajo además, logra determinar, entre otras datos que arroja, que el grado de alcoholismo de una persona depende de sus características raciales, "de la normalidad de su estado psíquico y del efíciente funcionamiento de los órganos emuntorios [se logró determinar también] que la raza indígena es más sensible al alcohol" (p. 473), y que la intoxicación "por una de las peores bebidas fermentadas como es el guarapo", típica bebida indígena, no difiere del aguardiente o el alcohol.

En cuanto al tabaquismo preocupa su consumo sin control y sin reparo en las consecuencias para la salud y la economía familiar. El trabajo muestra en cifras que con lo que gastan en tabaco en diez años, los consumidores habrían podido adquirir una pequeña casa. Pero lo que más desespera a Cruz, es que el Estado tenga el monopolio de la venta de estos tóxicos y no tome conciencia del daño que provoca a la población y a la producción laboral porque está más interesado en los ingresos que puede tener de la vente de estos tóxicos. Así que son las mismas autoridades las que deben despertar y tomar conciencia de la necesidad de la higiene mental como política del Estado.

Sobre la necesidad de extender la Medicina Preventiva, en un estudio realizado sobre la "Higiene Mental del Empleado Público", Cruz Cueva (1955) advierte sobre la preponderancia de dos factores determinantes de perturbaciones psicosomáticas, psicosis, anomalías de conductas de padres e hijos de empleados públicos. Estos factores son el económico (del que depende la salud emocional) y el consumo de alcohol. Para ello sugiere empatar "el costo de la vida" (los ingresos por salarios) con las "necesidades biológicas", aliviar los problemas de la desocupación a través de seguros de enfermedad y cesantía, extender prestaciones a los familiares de afiliados sobre todo con dispensarios de higiene mental, dar estabilidad al empleado público con derechos de ascenso, condenar a los Estados que usufructúen del monopolio del alcohol, impartir educación antialcohólica en zonas urbanas y rurales, tecnificar la carrera de trabajo social ya que "la Trabajadora Social es la mejor embajadora del higienista" (p.599).

Vemos aquí como los propósitos de la Higiene Mental dan cuenta de un contexto de luchas y expectativas sobre el tipo de sociedad que idea y defiende la psiquiatría, y que forman parte de las búsquedas que sustentan la conformación de objetos de conocimiento de la psiquiatría a mediados del siglo XX. La Higiene mental se presenta como parte sustancial de las búsquedas profesionales y políticas de la psiquiatría. Comencemos a explorar cómo se configura el marco político y profesional cuando las nociones eugenésicas e higiénicas entran imbricadas en la escena en la que se proyectan los objetivos que involucran la construcción del espacio simbólico de la nación. 


\subsection{La eugenesia en el Ecuador y los Archivos de Criminología en la Casa de la Cultura Ecuatoriana}

La segunda época de publicación de los Archivos de Criminología a mediados del siglo XX se imprime con el aval y apoyo de La Casa de la Cultura Ecuatoriana (CCE), una institución de Estado, que según Polo (2002), desde su fundación en la década del 40 y hasta la década del 60 , orientó sus actividades a la recomposición del espacio simbólico de la nación a través de una búsqueda por la definición de la identidad nacional, misma que consistió en puntualizar lo que es la ecuatorianidad. Esta búsqueda se desarrolla inmediatamente después de la derrota y pérdida del territorio con el Perú en 1941 (p. 40). Esta segunda etapa en la producción de objetos de saber psiquiátrico coincide entonces con la focalización de la identidad y la cultura nacional como problema de Estado. Problemática que se instituye en un proceso de configuración del campo intelectual en el que el intelectual y la nación pasan a formar una comunidad política y culturalmente imaginada.

Aquí, la toma de posición sobre la nación, según Polo (2008), es un hecho político, apuesta por intereses de clase e implica una legitimación sobre un ejercicio de poder, de dominación simbólica y de elaboración de un relato de la historia nacional. En ese entramado, considera el autor, se sitúan los objetos de saber legítimos/legitimados, y se imponen al intelectual una labor en relación a la elaboración de la historia nacional (39). Las problemáticas que surgen de la preocupación por la identidad y la cultura nacional pasan a ser el escenario de inteligibilidad de los objetos así como un horizonte de expectativas $^{4}$.

Para explicar el proceso y los mecanismos institucionales y culturales de la reconstrucción de la narrativa de la nación que pasó a ser un imperativo social y cultural de proyección al futuro del país, y parte central del orden simbólico así como del capital cultural del Estado nación y de "restructuración del orden social resquebrajado" por la pérdida territorial (Polo, 2002, p. 50), el autor describe las problemáticas del campo intelectual y sus principales discursos. Estos son:

- El cuerpo simbólico de la nación como objeto de una práctica reflexiva en la que se propuso la articulación de las voces subalternas como las del mestizo, el cholo, el montubio y el indio en las novelas y cuentos del denominado realismo social. Esa preocupación surge en los campos político y cultural junto a un resurgimiento nacionalista posterior a la pérdida territorial tras la guerra con el Perú y durante un periodo de hegemonía de la CCE.

- Los conceptos que articulan la reflexión y la elaboración del nuevo relato de la nación y la identidad nacional así como el reordenamiento simbólico son: la ecuatorianidad, cultura nacional, patria (la palabra equivalente de nación en aquel entonces) y mestizaje.

\footnotetext{
${ }^{4}$ Este y otros conceptos que se abordan aquí, son desarrollados en detalle en el capítulo metodológico.
} 
- Por la definición de la ecuatorianidad, en la lucha por alcanzar la definición legítima de la nación, una lucha por hacer creer, ver e imponer una visión del mundo, inmediatamente después de la pérdida territorial, se enfrentaron dos posturas: Hispanismo (toma como referencia las tradiciones y culturas hispánicas y su importancia en la cultura ecuatoriana) y nación mestiza (síntesis asimétrica de los elementos indígenas y blanco-españoles). Ambas posturas coparticiparon de varios elementos centrales con los que construyen su definición de nación tales como: un discurso teleológico de origen, una perspectiva racial, un relato nacional y una negación del otro, especialmente del indígena.

- Cuando la CCE absorbe al realismo social éste deja de ser insurreccional y los subalternos que se expresaban allí pasan a ser objeto de un interés político de Estado, racial y de clase, y se convierte en patrimonio común, pues gracias a la CCE pasa a ser imagen para la composición del ser nacional.

- Una reelaboración de la historia ecuatoriana a cargo de un grupo letrado.

- El intelectual ya no está mediado por un partido político sino por una institución estatal.

La CCE se inclinó por el mestizaje y según Polo (2002), su postura por alcanzar el monopolio de la legitimidad cultural, se halla condensada en la denominada "Teoría de la pequeña nación" de Benjamín Carrión. Su principal preocupación "versa sobre el 'destino de la patria" y ubica su concepto de ecuatorianidad en el marco del resurgimiento ético y de resistencia de la nación frente a la arbitrariedad de los gobernantes del país quienes adolecían de espíritu patriótico (45). Para Carrión era fundamental "recordar" para recuperar una esencia olvidada de la ecuatorianidad en la que denominaba el "tropicalismo". El autor nota que el "tropicalismo" es una idea vitalista que elabora un concepto de nación que conjuga una realidad integral: física, económica y biológica.

En un contexto de desconfianza y desánimo respecto de los símbolos nacionales que han perdido su efectividad de aglutinamiento de la población, de convocatoria y legitimidad cultural a causa de la derrota en la guerra, el acto de rehacer la nación y su historia "recordando" las esencias olvidadas cobra sentido, pues es "en el rescate de esas esencias olvidadas, [en] donde se produce el quiebre, y se abre la posibilidad de realizar una sistematización explicita del nuevo mundo simbólico: la nación mestiza." (Polo, 2002, p. 46).

En este recuerdo-recuperación de la esencia ecuatoriana la rebeldía aparece como otro de sus caracteres mayores, solo que la rebeldía con la que se escribe la historia de la nación aparece como un atributo más de los blanco-mestizos. Benjamín Carrión, según Polo (2002), no nombra ninguno de los levantamientos indígenas. El indígena en la versión de nación de Carrión es una ausencia, pues la exaltación del mestizaje desconoce a los indígenas como una cultura que termina "diluida" en el mestizaje. 
Carrión mira el pasado con un sentido de urgencia hacia el futuro dado por el presente de la nación y desde allí reescribe su historia y la proyecta hacia el futuro. En esa redefinición del pasado y proyección a futuro de la nación el indígena del presente ocupa un lugar como ser incivilizado, sin capacidad de autogobierno y de creación de un saber sobre sí mismo; está presente como campesino proletario, es decir como clase y no como realidad étnica, y finalmente ocupa un lugar como objeto de estudio de los saberes modernos que se expanden por el país a causa de la modernización del Estado.

La recuperación de la nación requería de una mirada hacia adentro de la que derivaría una verdad que nace de la investigación de los problemas propios del país. La "modernidad cultural" (Polo, 2002), apuesta por una verdad que proviene de la indagación sobre el propio ser nacional y que, a través de ello redefine la historia patria para proyectarla a su futuro. Redefinición e investigación que incluye silencios y olvidos sobre la realidad étnica del país. Y en este marco, la problematización de la ecuatorianidad no significó tomar como objeto de reflexión la realidad preexistente, más bien significó una "invención del mundo circundante y del espacio simbólico con sus clasificaciones y su jerarquía social; es el lugar donde se juega lo que se va a entender como la verdad y la mentira de los acontecimientos históricos, donde se establecen taxonomías sociales; finalmente es el lugar a partir del cual se levanta la exterioridad y la interioridad del ‘cuerpo' de la nación.” (p. 50).

Esta es la institución de Estado que acoge la segunda época de publicación de los Archivos de Criminología, una institución que instala una modernidad cultural al definir las reglas de juego del campo cultural y el deber ser del intelectual, que a su vez, moviliza un tipo de imaginación de la nación compuesta por silencios y olvidos sobre la realidad étnica del país lo que implicó una redefinición de la historia patria con una proyección utópica de su futuro. El estado y los intelectuales se han volcado hacia una imaginación utópica de la nación.

Ahora bien, ya en el siglo XX una imaginación de nación se había propagado en el campo médico. El higienismo es muestra de ello. El campo médico estaba atravesado por una forma de imaginar el pasado, el futuro y el presente de la nación. Una imaginación que se desplegó en la organización de la ciudad, en la forma de ejercer la medicina, de comprender la normalidad y la patología, de delinear las normas de convivencia de la población de establecer las jerarquías sociales y de significar el espacio simbólico de la nación: una visión de mundo.

Eduardo Kingman (2008) sostiene que el ethos barroco permite la coexistencia entre varias modernidades en el caso andino, y por ello si bien la modernidad se identificó con la idea 
de Progreso y ornato ${ }^{5}$, su emergencia no respondió a la transformación de los modos de producción, sino más bien a la articulación de las ciudades y del Estado al mercado mundial y a proyectos de modernidad particulares ligados al mundo de la hacienda, a la plantación y el desarrollo de un tipo de capital no productivo.

Es así que a finales del siglo XIX y principios del XX, en el umbral de la "primera modernidad" (Kingman, 2008), el contexto urbano estuvo marcado por el deterioro de las relaciones sociales del Antiguo Régimen y la emergencia de nuevos sectores en la escena urbana. Ello no significó el paso de una estructura a otra, sino la coexistencia simultanea de órdenes sociales en los espacios urbanos donde se reproduce también el sistema de haciendas. Según el autor, irrumpirían en el espacio urbano una servidumbre urbana proveniente del mundo rural y una clase media que en las ciudades andinas no se articulan en estructuras capitalistas, sino en una especie de economía política del símbolo que se condensa en la idea de decencia. Un proceso similar se encuentra en Perú donde la decencia jugó un rol fundamental en la definición biológico/moral de la raza como base de la identidad de la élite blanca, la definición identitaria del mestizo/a, los cholos y el neoindianismo (de la Cadena, 1997).

Ahora bien, una segunda generación de salubristas se constituyó como una corriente medico social positivista y biopolítica en la que, desde los años treinta, se afianzó con la prevalencia de criterios científicos y técnicos orientados a generar un crecimiento normal de la urbe y su población. Esta generación hizo prevalecer los criterios de la medicina social moderna. "El higienismo constituyó en el Ecuador, como en otros países, una verdadera escuela de pensamiento médico y social, estrechamente ligado a las prácticas estatales y municipales de salubridad y seguridad social, así como a la cátedra y la investigación universitarias. Su interés básico consistía en mejorar las condiciones de vida y de salud del conjunto de la población.” (Kingman, 2008, p. 302).

\footnotetext{
${ }^{5}$ Esta noción de Kingman (2008) hace referencia al principio de ordenamiento urbano que nace en la segunda mitad del siglo XIX y principios del XX. Su procedencia se remite a las estructuras de clasificación social y racial de lo que denomina "ciudad señorial" y también en la forma en la que es asumida en la primera modernidad. El ornato, según este autor, es entonces una forma de vivir y dividir el mundo, es la expresión de una cultura que establece sus diferencias sociales a partir de criterios de distinción simbólicos de un tipo o una forma particular de modernidad. El ornato en consecuencia, es un dispositivo de poder que permite ordenar y administrar las cosas, las personas sobre la base de lo que Rufer (2010a, 2010b) denomina como formas binarias, y que en el caso de Ecuador, según Kingman (2008) son constituidas en el sistema de oposición campo-ciudad. A través de esta noción por ejemplo, el autor manifiesta que la clase media dependía de su capacidad de negociar una posición dentro de los sistemas de clasificación social y espacial de la ciudad. Ocupar un lugar social y físico en la urbe, condujo a la clase media a vehiculizar ideologías y prácticas de élite para distinguirse de las clases populares y de los indígenas, sectores sociales que no están considerados como urbanos.
} 
En esta corriente médico social se gesta una asociación de la miseria con la enfermedad, algo que también ocurriría en Europa y América Latina. Por ejemplo, en este momento político, médico, social y cultural de modernización que me encuentro describiendo, la

Revolución juliana permite una comprensión dialéctica del proceso asimétrico salud-enfermedad ocurrido en el país en el siglo XX frente al cual el alfarismo radical (la Revolución liberal) y la Revolución juliana asumieron posturas que deben ser miradas en el entorno de un proceso de construcción del Estado nacional. Si la Revolución liberal definió que frente a los conflictos de la salud el Estado debía asumir el rol específico de atender a los enfermos para curarlos oportuna y adecuadamente, la Revolución juliana dio un paso trascendente al trazar una línea de trabajo estatal para atender la salud colectiva y, además propiciar las medidas profilácticas que evitaran la enfermedad ${ }^{6}($ Rodas, 2011, p. 106-107).

Pero también hubo una asociación de la patología con la idea de raza. Según Kingman (2008), raza y nación formaban un mismo cuerpo para la década de 1940, lo que generaba una lectura que hacía equivalente a la una con la otra: lo que ocurría con la raza ocurría con la nación y viceversa (p. 305). Entonces si la enfermedad y la degeneración moral y física tocaban a la raza lo hacían también con la nación. La raza tenía un sentido moral en mayor medida que antropológico.

De allí que las prácticas salubristas se hayan ligado a las de prevención social y profilaxis, y estas se hayan inclinado hacia la disciplina y el mejoramiento racial para la protección del cuerpo social útil de la población. La previsión social era una institución

fundamentalmente urbana: resultado de la constitución de un nuevo escenario social y de sectores sociales con otro tipo de hábitos de trabajo. (...) la previsión social se convirtió en un asunto eminentemente público, que preocupaba al Estado, (...) que permitía extender los mecanismos de control hacia el ámbito privado. (...) estaba ligada a la generación de habitus ciudadanos entre los sectores populares. (...) se orientaba hacia una racionalización de las condiciones laborales y de vida de los trabajadores (...) Sus acciones estaban dirigidas tanto a mantener la vida como a modificar la forma de vida. Al hacerlo producía, al mismo tiempo,

\footnotetext{
${ }^{6}$ Se denomina comúnmente Revolución Liberal a un periodo de transformación política, económica, cultual y social que inicia en 1985 en el Ecuador. El liberalismo logra imponerse tras una guerra civil en la que se enfrentan con los gobiernos que sucedieron al garcianismo que fue una forma de gobierno que impulsó una modernidad que aliaba a la Iglesia Católica con el Estado. Los liberales promovieron la separación del Estado y la Iglesia en pos de una Modernidad Laica en la que pasaron a cimentarse las concepciones de ciudadanía, democracia y Estado-Nación. La Revolución Juliana acontece el 9 de julio de 1925. Fue un movimiento cívico militar que se extendió seis años y que transformó el Estado Liberal plutocrático en un Estado de Bienestar. Este cambio tuvo una fuerte impronta en el área de la salud puesto que permitió la extensión y aplicación de la salud colectiva que más tarde derivaría en lo que actualmente se denomina como salud pública.
} 
diferencias al interior de los sectores populares en torno a patrones civilizatorios. (Kingman, 2008, p. 306-307).

La prevención social o más tarde conocida como Seguridad Social pasó a ser un modelo civilizatorio de la nación. Prevenir para formar un país civilizado. La higiene y la prevención actuaban como una tecnología para la vigilancia y la generación de comportamientos civilizatorios (costumbres de higiene, buenas normas). En este modelo civilizatorio la estadística y la antropometría (ver cap. 4), actuaban como aparatos de control de la población y sirvieron para la producción de tipologías corporales como una práctica de clasificación que apuntan a la administración de carácter racial sustentada en un criterio de autoridad. Este modelo de control permitió además el surgimiento de la garantía de leyes específicas para los trabajadores para impedir que la explotación afectara su capacidad laboral. Esto sucedería, según Rodas (2011), sobre todo después de la Revolución juliana en 1925 (p. 107).

En este marco, dice Kingman (2008), la medicina social toma al espacio social como "laboratorio social". El Espacio social es asumido como ámbito apropiado para el conocimiento y la experimentación con fines de mejoramiento social. La higienización pasa a marcar pautas universales de comportamiento, administración y formación de habitus, mejorar cuerpos a través de un mestizaje biológico y cultural y a través del mejoramiento de condiciones de vida. Así, la medicina pasa a velar por la prosperidad de la nación y hunde su práctica en el proyecto civilizador que pretendía mejorar costumbres e integrar a distintos sectores, pero que reprodujo el sistema de hacienda, en "la vida cotidiana se intercalaban las enseñanzas de la moderna medicina social con los sentidos incorporados de la decencia, el ornato y adecentamiento urbanos" (p. 326).

Así, mientras el ornato era una institución que creaba sentidos, moldeaba gustos, delineaba límites entre lo culto y lo inculto, evaluaba, generaba comodidades, configuraba una visión de la "arquitectura social" al moldear el comportamiento de las élites y sus criterios de distinción con los otros, es decir, mientras el ornato separaba, el higienismo desarrollaba prácticas civilizatorias y este carácter creativo, dice Kingman (2008), no era ajeno a la eugenesia (p. 327).

La eugenesia estaba relacionada con la idea de mejoramiento racial, colocaba a la ciencia como vía de una sociedad hacia su mejoramiento a raíz de la erradicación de la degeneración, era un foco de imaginación de la nación y colocaba a la biología en un lugar central para leer lo social creando un juego de lectura pendular entre la biología, sociedad e historia, a tal punto que como veremos más adelante, sus postulados permiten una argumentación y una relectura de los mitos nacionales para darles un nuevo estatus de verdad. 
En la práctica, dice Kingman (2008), los cultores de la medicina social combinaban sus propuestas de mejoramiento cultural y social con prácticas alineadas a la eugenesia (p.327). Paulette Serrano (2016) agrega que lo que sucedió en Ecuador es que la idea de mejoramiento genético se mezcló con la idea de prevención por medio de la higiene; es decir, la eugenesia se despliega como una forma de prevención higiénica (p. 7). Ello es visible, según la autora, en el control que el Estado ecuatoriano ejerció en el cuerpo de las trabajadoras sexuales en la década de 1920 durante la primera modernidad que alcanza Quito.

La sífilis, la tuberculosis y el alcoholismo se habían convertido en los focos de atención de la medicina (Rodas, 2011, p.39) y fueron consideradas los más grandes males morales, y al ser asumidos desde la eugenesia, la perspectiva de mejora genética se mezcló con el control de las enfermedades venéreas lo que condujo a la medicina social a posar la mirada sobre el trabajo sexual (Serrano, 2016, p. 5-7).

En 1921 se fundó la Dirección General de Sanidad (DGS) encargada de coordinar e incentivar la creación de reglamentos y guías para la regulación de la higiene a nivel nacional. Cinco años después se crea la sección de profilaxis sexual y con ella se reglamenta el trabajo sexual. En esta institución confluye la mirada higiénica con la eugenesia para generar una lectura de la enfermedad venérea, la sexualidad, el matrimonio, el mejoramiento social, el cuerpo de la mujer y la nación. El progreso actuaría como hilo conductor de estos aspectos. Según Serrano (2016), médicos de la época como Díaz Cueva y Domínguez afirmaron que el progreso material y cultural de una nación dependía en gran medida de las sanas costumbres. De allí que la sífilis fuera un obstáculo ya que su fácil contagio y sus efectos eran perjudiciales para el individuo, la sociedad y la especie ${ }^{7}(26)$.

La eugenesia y el higienismo desde los años 20, y la modernidad cultural desde los años 40 y 50, permiten tejer marcos teóricos para una utopía en Ecuador. Esta utopía consiste en que el progreso de la nación por un lado depende de una indagación moderna y científica sobre el propio ser nacional. Ello derivó en una elaboración de taxonomía para la definición de jerarquías sociales en gran parte sustentadas en la reelaboración de las

\footnotetext{
${ }^{7}$ De este argumento surge la necesidad de tutelar el matrimonio a través de la certificación médica de la salud sexual (certificado prenupcial). Esta forma de previsión miraba al futuro puesto que su objetivo era evitar que la enfermedad traiga efectos a los hijos que "deben ser concebidos" dentro de los matrimonios (como necesidad médico social y como exigencia para el bien estar moral y nacional). Es decir, la prevención cuidaba la herencia, los caracteres que no eran solo de índole biológica sino de "cualidad" ya que el recién nacido recibía las buenas costumbres a través de la leche y la sangre de la madre. Se trataba de procurar no traer al mundo "seres inferiores" que degeneren la especie y que arriesguen el progreso del país. Por ello, sostiene Serrano (2016), se promulgó la sanción penal a quien traiga al mundo seres discapacitados. El matrimonio y el control de la sexualidad (de las parejas heterosexuales católicas y sobre todo de la mujer y más aún el de la prostituta) pasan a ser una de las prioridades de un "Estado higienista" para el cuidado de la salud y el futuro de la nación (p. 26-31-32-34-65).
} 
supuestas esencias físicas, culturales, económicas y biológicas del ser nacional que tendió a ocultar la realidad étnica del Ecuador.

Por otra parte, la utopía alimentada por una imaginación proveniente del ornato y la higiene, por la vivencia y división de mundo y su civilización, finamente llega a considerar la eliminación de la patología para el arribo a una nación ideal. La ecuación en el nuevo discurso médico se puede expresar del siguiente modo: ¡A menor patología mayor progreso! Es importante tomar en cuenta esta forma de concebir el progreso como un avance a la sociedad sin patología porque ésta se extiende no solo a la tuberculosis, al alcoholismo o las enfermedades venéreas sino a toda forma de patología que le signifique a la nación un retroceso.

La preocupación sobre estos "males" la encontramos extendida en una discusión acerca de la determinación y definición científica de la normalidad o anormalidad de los indios de la serranía ecuatoriana. Este debate fue publicado en los Archivos de Criminología hasta la década del 60 . 


\section{CAPÍTULO 2}

2.- Metodología 
En este capítulo se desarrolla una discusión teórica alrededor de la relación entre modernidad, la Nación, los usos sociales de la temporalidad, la raza, la identidad, las instituciones de saber y los objetos de saber, el campo de visibilidad y la producción de narrativas. Conceptos y posturas que forman parte de un marco con el que se realiza la interpretación de las fuentes y que se nutre de corrientes diversas como la Historia conceptual, la Teoría poscolonial y las Teorías sobre las memorias.

\subsection{Modernidad y nación}

Perseguir lo nuevo, poseerlo, habitarlo, promoverlo, exhibirlo, proponerlo, eso parece ser un rasgo de modernidad, el indicador de que se está en la modernidad. Después de todo, en la modernidad, la búsqueda de lo nuevo, la vivencia de la novedad es un valor o se promueve como tal. Pero, ¿qué sería lo nuevo...qué sería y cómo se presenta lo moderno?

Mario Rufer considera la posibilidad de que "el éxito de las narrativas occidentales que universalizaron las formas legítimas de la experiencia social y política de los pueblos, radique en que la 'modernidad' -y la fuerza vectorial que compele este término- es un vocablo que acuña un 'significante que flota', ${ }^{8}$, como las palabras que no pueden designar unívoca y exactamente lo que nombran. Esas palabras, en la semántica de las relaciones de poder, siguen siendo las más productivas por las múltiples voces que sus usos confieren." (Rufer, 2004, p.767). Es en esa multiplicidad de voces, de usos y prácticas donde el signo modernidad fuga sus significados concretos.

Paradójicamente, entonces, según Rufer, al acuñar un signo que no remite a una abstracción concreta, la universalidad de la modernidad deviene - y ahí radicaría su eficacia- en un(os) acto(s) de universalización en modernidades localizadas y con efectos sociales concretos, con fisuras o alteración de las creencias e invenciones de realidades yuxtapuestas a otras realidades. Al unísono de este devenir de los universales, la modernidad ilustrada europea, al ser enunciada, por un lado forma parte de una oposición binaria frente a la colonia, a la tradición y al retraso. Por otro lado, la modernidad ilustrada europea pasa a ser al mismo tiempo una forma binaria desde la cual se nombran esos binarios (modernidad-colonia, modernidad-tradición, modernidad-retraso) y ello deriva en unas formas analíticas que articulan la producción de sentido de los actores sociales que reordenan sus realidades a partir de este locus binario.

Esta forma binaria ilustrada europea al atravesar la experiencia social y política, lo hace no sin producir formas de conocimiento locales. Además, esta binariedad envuelve las formas de conocimiento y de experiencia en una constante creación de fronteras y distancias entre sujetos y temporalidades. Esta complejidad se puede ver reflejada en la problemática de la nación, precisamente en las especificidades y formas particulares de conocimiento y experiencia que producen sus proyectos modernizadores. Y si expresa esta problemática es

\footnotetext{
${ }^{8}$ Rufer toma está metáfora de Raymon Williams.
} 
porque efectivamente "la nacionalidad es el valor más universalmente legítimo en la vida política de nuestro tiempo (...) [y porque] Ninguna nación se imagina con las dimensiones de la humanidad (...) Se imagina soberana (...)" (Anderson, 2007, p. 19-25) particular, limitada.

Anderson sugiere dentro de esta problemática que, por ser "invenciones" inscritas en una concepción de tiempo ilustrado, el Estado moderno, la revolución y el nacionalismo no tienen patentes. Al no tenerlas, pueden ser ensayados, copiados en otras sociedades distintas a las de origen de la teoría. Por ello, literalmente "están disponibles para la piratería" (Anderson, 2007, p. 222). Para este autor además, estos conceptos son indicadores de lo que es el adelanto y de lo que es el retraso. Es decir, son parte de esos demarcadores de fronteras que anteriormente se mencionó. Delinean, en parte, ciertas fronteras respecto de quienes alcanzan la revolución o el Estado moderno (el adelanto) y quienes no (el retraso). Trazan fronteras, entonces, entre lo nuevo y lo viejo, entre un tiempo y otro, entre un tiempo actual-presente y un pasado.

La modernidad, entonces, se apoya en lo que Rufer (2004) ha encontrado como la idea de una "dislocación" que ha tomado varias formas. Es un desplazamiento y como tal produce efectos así como sentidos sociales en las prácticas. A su vez funciona como una ruptura. "En el proceso productor de esta idea, el sujeto teórico supremo (Europa) ha construido (...) los binarismos clásicos con los que (...) aprehendemos parte de la realidad social y "localizamos" nuestro mapeo cotidiano de sujetos y espacios: Tradición-modernidad, y de allí, mito-historia, razón-irracionalidad, comunidad-nación, etcétera.” (Rufer, 2004, p. 760). Me centraré en la oposición tradición/modernidad. Considero que a través de una reflexión sobre las implicaciones de esta dislocación se pueden rastrear los sentidos políticos y sociales del tiempo; las formas en los que la modernidad se cargó de sentido concreto en una historia nacional; los usos no especializados de la historia; los usos sociales de las distancias temporales como productores de sentido sobre el pasado y constructores de los otros de la nación. Finalmente, interpretar la importancia que tiene esta fractura y los usos sociales de las distancias temporales para la inteligibilidad de los objetos de saber psiquiátrico y sus nexos con una etapa de la narrativa de la nacionalidad ecuatoriana.

\subsection{Tiempo moderno, colonialidad y nación}

He dicho que la modernidad deviene en un acto de universalización, en modernidades adaptadas que producen efectos sociales concretos que yuxtaponen una realidad con otra. Los efectos sociales y la yuxtaposición de realidades están dados por una concepción de tiempo que emana de la dislocación que produce el binarismo moderno. Según plantea Anderson (2008), el tiempo medieval, atravesado por el pensamiento cristiano, no concebía la historia como una cadena interminable e ininterrumpida de causa y efecto. Tampoco separaba tajantemente el pasado del presente. El tiempo es simultáneo. Con la retirada de Dios del mundo, es decir, con la retirada de la deidad como referente para la comprensión 
del tiempo, la filosofía de la Ilustración se distancia de la idea del plan divino que marcaría la apertura total para el advenimiento de un proceso de laicización de la historia. Este proceso secular enmarcó el tiempo en una concepción lineal y procesual. El presente aparecerá separado del pasado.

Rufer comprende que es a través de la integración camuflada de esta concepción que la historia se constituye como disciplina, dispone un modo de "hacer historia" ligada a la evidencia, la homogeneidad, el telos-destino y a un lenguaje de autoridad cuyo centro de sentido es el proceso. Pero para que esta idea de proceso pueda expulsar toda forma de tiempo que no le sea propia, "no solo debe conectar discursivamente los marcos acontecimientales, también tiene que incluir la idea de progreso. Como lo muestra Giorgio Agamben, proceso y progreso se entrelazan en el telón de fondo del conocimiento histórico junto con la vertientes del capitalismo decimonónico de desarrollo y evolución." (Rufer, 2010a, p. 20).

A ello se debe que la noción de un telos-destino, de una concepción sobre la continuidad temporal que tiene como eje la realización del progreso, permita la idea de una “emancipación progresiva del género humano gracias al triunfo de la Razón, capaz de conquistar en cada etapa una mayor transparencia. Este optimismo va a desembocar en la filosofía de la historia -Kant, Hegel, MarX- que marcará a todo el siglo XIX (...) Los hombres creen que hacen la historia, la suya, mientras que ella se desarrolla a sus espaldas y sin su consentimiento, frase que sigue la famosa idea de las trampas de la razón." (Dosse, 2013:38). Para este autor la fe ciega en este telos-destino significó la expulsión del acontecimiento y posibilitó la homologación del tiempo. Acontecimiento expulsado y homologación del tiempo serían parte de aquellas trampas de la razón moderna.

La homogenización del tiempo implicó también la expulsión y desvaloración de otros usos sobre el tiempo a través de la legitimación de unas formas de construir el sentido sobre el pasado mediante la producción disciplinar de la historia. Esta nueva concepción de la temporalidad social, el tiempo moderno, el tiempo secular, es un tiempo vacío, y donde la simultaneidad "es transversa, de tiempo cruzado, no marcada por la prefiguración y la realización, sino por la coincidencia temporal, y medida por el reloj y el calendario." (Anderson, 2007, p. 46). Para Anderson, la expansión de esta imaginación sincrónica sería posible, en parte, gracias al "capitalismo impreso", la producción serial industrial de relojes y la formalización de la historia como disciplina. Considera que tras la formalización de la historia-disciplina toda ruptura pasó a estar integrada dentro de la misma serie histórica del tiempo histórico.

Paúl Ricoeur (2000), al respecto, menciona que en la modernidad el tiempo del calendario pasa a ser el ahora absoluto del momento presente. En el tiempo moderno del calendario se inscriben los acontecimientos definiendo su distancia con un tiempo pasado y un porvenir. Define y distancia lo que es del presente (lo nuevo) de lo que es de un tiempo anterior y de 
un tiempo futuro (que es el tiempo que se espera). Este tiempo, es ordenado por lo que denomina las "grandes cronosofías", las grandes representaciones con pretensión de fidelidad de la memoria. Tiempo en el que entran todas las temporalidades, en el que todos los tiempos son del tiempo calendario.

A pesar de las distancias que se pueda apuntar entre un autor y otro, esta idea de Ricoeur permite señalar una dinámica donde se constituye el "nosotros" del tiempo nuevo y el "otro" del pasado. Pues a la vez que se traza una línea divisoria entre presente y pasado y una forma veraz de delinear los relatos que definen sus diferencias, en dicha definición se incluye a los sujetos que habitan cada uno de estos límites. Las grandes cronosofías son narrativas absolutas disciplinares que producen el pasado marcando una distancia con el presente, y en dicha representación "fiel", también se demarcan líneas divisorias entre sujetos del presente y sujetos del pasado. Las "grandes cronosofías" producen sujetos alterizados. El "otro" del tiempo pasado es abstraído a esta dinámica a través de las categorías e instrumentos científicos.

Y en el mismo movimiento el tiempo es exteriorizado de la historia. La configuración de una percepción que establece que el tiempo avanza de una forma lineal que va desde tiempos remotos hacia tiempos nuevos y futuros, la reflexión sobre la forma de concebir y determinar las distancias y diferencias entre tiempo nuevo y antiguo, se anula, desaparece, se ausenta como parte de la comprensión del discurso histórico, como parte de su andamiaje. El tiempo pasa a ser un implícito, tácito, más no parte del discurso. Es así que la historia pasa a ocultar su lugar de enunciación: el trabajo con y sobre el tiempo (Rufer, 2010a).

Rufer señala que para el caso latinoamericano, junto con la matriz colonial, la exterioridad del tiempo acarrea la ocultación de las temporalidades existentes mediante las narrativas de los estados-nación. De allí que considere que es el tiempo y su aprehensión (desde una semántica histórica y una hermenéutica de la conciencia histórica que emana del caudal de la contemplación de la tensión entre experiencia y posibilidad) lo que entra en escena. Es el tiempo lo que está en disputa. Su irreductible presencia. Su uso ${ }^{9}$ político. La exteriorización del tiempo actuaría como un dispositivo de arcaización de todo aquello que no cabe en la acepción del tiempo moderno, del tiempo lineal, del proceso-progreso. Esta postura política consistiría, en parte, en interpelar a la Historia en esa supuesta ausencia del tiempo moderno de los pueblos arcaizados, retomando el tiempo de la historia (nacional) como una noción política

\footnotetext{
${ }^{9}$ La respuesta frente a esto según el Rufer (2010) será abordar el tiempo, pensarlo ya no como algo que se da por hecho, sino como algo que de no ser complejizado reproduce su homologación. Pues ello implica -si seguimos la argumentación del autor- el retorno de las multiplicidades temporales arcaizadas por esta operación de exteriorización del tiempo de la historia en su acepción moderna ilustrada binaria. Esta operación constituye el recurso hacedero más fecundo en la edificación de los Estados poscoloniales latinoamericanos..
} 
En Europa, a partir de la configuración del binarismo moderno, los Estados conciben su propia sociedad (al parecer, no en su conjunto) como poseedora de historia en tanto que es moderna y progresa. Ello le da la característica diferenciadora respecto de aquellas culturas arcaicas, retrasadas, sin historia, tanto de las que habitaban sus territorios como de las denominadas del tercer mundo. La historia como disciplina se erige para la diferenciación entre lo moderno y lo arcaico, entre el otro y el nosotros, entre lo europeo y lo demás. Entonces, si se trata de hacer aprehensible el carácter político del tiempo es para evidenciar las distintas formas en las que se ha expresado el binarismo moderno europeo en el contexto latinoamericano. Ya sea como parte de las búsquedas ideales de las narrativas nacionales, ya sea como sustento implícito de la conformación de saberes, instituciones, y construcción de alteridades nacionales, ya sea en prácticas instituidas que derivan en políticas de Estado direccionadas a intervenir en la cotidianidad y la percepción de las poblaciones.

Problematizar el tiempo propone una ruptura, marca la posibilidad de crear una narrativa histórica que se aparte de la universalidad homologadora y homogenizadora de la versión europea de la historia. Versión que -según Rufer (2004-2010a-2010b)- negó para la diversidad de América Latina la posibilidad de construcción de esa narrativa sin la tutela de los presupuestos de la disciplina histórica y sobre todo de los estados nacionales que reconstruyen sus pasados en torno a esos postulados. Postulados que se hicieron posibles gracias a la exteriorización del tiempo de la historia y a que los estados heredan una matriz colonial que entrena, educa y perfila la mirada de las naciones poscoloniales frente a sus diversidades, creando signos-raza específicos enmarcados en proyectos nacionales. Estos aspectos actúan en este proceso como herramienta de desplazamiento de otras apropiaciones de tiempo y modalidades de temporización. Historia, tiempo y colonialidad son conceptos entrelazados (es aquí, según este autor, donde radica la diferencia para el debate sobre la temporalidad en América Latina).

La imaginería de la nación sería uno de los escenarios en donde Historia/tiempo/colonialidad se entrelazan. La nación, como sugiere Anderson (2007), en parte emana de la oficialidad del Estado y responde a los intereses estatales. Entonces, al corresponderse con el orden y el dominio político, el uso del tiempo coincide con la imaginación de la nación. Y en la imaginación de la nación se halla esa forma particular de la universalización del binarismo moderno, de modernidad localizada y la exterioridad del tiempo es garante de los objetivos de la evaluación del pasado, del presente y la producción de alteridad.

Con ello, plantea Rufer (2010b), el tiempo exteriorizado se constituirá en uno de los dispositivos de perdurabilidad, transmisión y propagación de la colonialidad en la gobernanza y administración de los pueblos. 
De allí que el tiempo sea entendido aquí como un régimen discursivo de representación que por tanto "corresponde al dominio político (y no al físico, ni al mecánico ni al psicilógico)” (Rufer, 2010a, p.13). Enonces, la noción de tiempo histórico se asimila dentro de un espacio de significación y autoridad, que politiza el tiempo vaciado por la "retirada de Dios" (Dosse, 2013) y homogeniza al sujeto de la nación para concebirlo ciudadano.

Las historias de las naciones latinoamericanas muestran en parte ese camino: la modernidad vernácula es una forma iterativa del discurso colonizante a partir del posicionamiento de élites criollas que desplazaron el discurso político hacia la realización nacional. En la historia-narración, el sujeto ciudadano (que en los países poscoloniales responde generalmente a un sujeto fallido, en transición, racializado, mestizo) reemplazó al dominado colonial bajo un aspecto que la historia hizo propio: la abstracción de las temporalidades múltiples (y los mundos de la vida divergentes) en la imagen omnicomprensiva de la nación homogénea independiente. (Rufer, 2010a, p. 15).

La modernidad vernácula, entonces, es una forma iterativa del discurso colonizante ${ }^{10}$ porque es una modernidad adoptada o exógena como la denomina Bolivar Echevería (2011). Y toda modernidad exógena proviene de un proceso de conquista e implica un

\footnotetext{
${ }^{10}$ Esa modernidad vernácula, exógena, nunca del todo moderna, nunca del todo racional, es oscilante, fallida es incompleta porque " la experiencia colonial, a la vez que está fundada en la justificación de la idea hegeliana de la historia (el "todavía no" [not yet] de la antropología imperial: primero aquí, luego allá), a su vez traicionó esa misma idea: la colonia no supuso el desarrollo (o la evolución del espíritu) en términos de una frontera a ser superada, sino que implicó la coexistencia híbrida de temporalidades que fueron domesticadas en los mundos de la vida de manera particularmente diversa y que hicieron imposible ya la noción de una historia universal única como desarrollo y evolución. El punto es que en términos discursivos, disciplinares, esa noción se mantuvo. (...) si la colonización es el proceso histórico eventualizado, la colonialidad es la condición bajo la que operan los procesos de subordinación (simbólica y material) que articulan los procesos hegemónicos contemporáneos". (Rufer, 2010a: 16). La modernidad vernácula, entonces, al oscilar entre lo endógeno y exógeno está a su vez inmersa en un proceso doble de inscripción: la colonización y la colonialidad. Cabe mencionar, además, que la colonialidad dista del colonialismo porque este último se refiere a un grupo de hechos históricos que inician con la conquista de América y finalizan con sus procesos independentistas. Apunta "a una relación política y económica, en la cual la soberanía de un pueblo reside en el poder de otro pueblo o nación (...) la colonialidad se refiere a un patrón de poder que emergió como resultado del colonialismo moderno, (...) se refiere a la forma como el trabajo, el conocimiento, la autoridad y las relaciones intersubjetivas se articulan entre sí, a través del mercado capitalista mundial y de la idea de raza." (Maldonado-Torres. En: Chaves, 2009, p. 13).
} 
grado de imposición de la identidad cultural de la modernidad endógena, de su sociedad y las metas de su empresa histórica sobre la identidad y las metas e intereses histórico de la exógena. Mientras que la modernidad endógena se afirma y se propaga con la marca de su identidad, la modernidad exógena "trae siempre consigo, de manera más o menos radical, un desquiciamiento de la identidad social, un efecto desdoblador o duplicador de la misma." (Echeverría, 2011, 153). Pienso, además que este efecto desdoblador se da porque la propagación de la modernidad endógena es parte de una interpretación constante y siempre inacabada de la modernidad exógena. El carácter de interpretación no puede ser subestimado.

La modernidad vernácula, entonces, es una modernidad escindida, desdoblada, oscilante entre lo endógeno y lo exógeno. Pero pese al desquiciamiento, es decir pese a que no es homogénea, ni única, ni dócil ni pasiva (pues, para Echeverría la adaptación no es del todo completa también porque implica resistencia y varios niveles de negociación), ésta busca siempre, como estrategia política, un grado de homologación que facilite la gobernanza y administración de los pueblos. Para Rufer (2010a) la abstracción de los mundos de la vida divergentes es fundamental en este proceso de transmisión, apropiación y adaptación de la modernidad y de homologación para la gobernanza, pues responde en consecuencia a la invención iluminista de la tradición.

La modernidad es expresión de la ruptura con la tradición. Es decir, la oposición entre lo moderno y lo tradicional, el locus binario es el elemento fundante de la posibilidad de entender el tiempo del devenir: el tiempo del progreso y de la autoridad de la razón. La tradición es un concepto que denota límite: nunca será del todo moderno lo que no quepa en el canon de la noción de progreso y razón. A partir de aquí lo moderno cabe en el futuroprogreso, el pasado en la tradición, es lo arcaico, lo retrasado. Es esta denotación de límite lo que permite la emergencia de la noción de historia y tiempo histórico secular sobre la base de otra noción emergente que será la de pasado histórico mundano. Y ese pasado histórico pasa a ser, en la noción de tiempo histórico moderno (lineal del progreso y la razón) lo que fue y lo que no debe ser más. Esta noción además, permite la conformación de un régimen de lo recordable, que define lo que se va a recordar (tiempo cronológico y trascendente, historia de héroes, genios y personas notables, tiempo histórico que se mueve hacia la evolución y el desarrollo) y cómo será recordado. Ese cómo del régimen de lo recordable se traducirá en términos de distancia. Esto es una geopolítica del tiempo: su espacialización. Al

"espacializar el tiempo, la diferencia cultural del Otro es concebida como distancia (...) La distancia que impone este imaginario se traduce en lo que Fabian denomina la 'enegación de la coetaneidad': invariablemente, el otro habita en el pasado ${ }^{11}$. Es esa dislocación entre un

\footnotetext{
${ }^{11}$ Rufer $\left(2010^{\mathrm{a}}, 2010 \mathrm{~b}\right)$, plantea que es aquí, en este límite entre lo moderno y lo arcaico donde se gesta la idea de que hay sociedades que viven un eterno presente etnográfico. Ello crea una separación entre disciplinas. Para cada sociedad habrá una disciplina que la aborde. Las sociedades de progreso, del tiempo
} 
tiempo global y su espacialización lo que determina usos opresivos del tiempo como una operación política de génesis histórica. El "punto de vista" del observador es el punto de partida del tiempo moderno, que no era sólo secular y naturalizado, sino ya en el siglo XVIII, nacional.” (Rufer, 2010a, p. 17-18).

Piensa este autor, la aplicación de esta concepción del tiempo histórico (exteriorización del tiempo, arcaizado, homogéneo en tanto que divisible, naturalizado, lineal en tanto que secuencial, simultaneo, vacío en el que todos los acontecimientos caben, espacializado, especializado, mundanizado, tradicionalizado, globalizado y de la nación) permite que el mito de origen de la nación funde un doble efecto de negación: a) niega a unos sujetos el ser sujetos modernos al ubicarlos siempre en el pasado arcaico y tradicional y b) no permite reconocer las condiciones de producción del discurso que posibilita esa arcaización. Es allí, en este doble efecto de negación donde se ancla por un lado el uso político del tiempo que vincula verdad-historia-nación en una "autorización poética (la trama narrada) de una modalidad política de la experiencia" y por otro la ocultación (tras un orden discursivo de ruptura de un orden histórico de continuidad) de "la condición violenta de producción y reproducción de las identidades en esa propia historia.” (Rufer, 2010a, p. 21). Y además, queda bloqueada la posibilidad de demostrar por medio del abordaje disciplinar la continuidad de esa experiencia violenta y racial (de despojo simbólico y material) entre ordenamientos coloniales y nacionales. A partir de estas escisiones se separan los "sujetos de la nación" de las comunidades consideradas o nominadas como retrasadas o premodernas. Es en un marco como este donde buscaré la concepción sobre lo moderno, lo patológico y sus nexos con la nación, el tiempo, la raza y el saber psiquiátrico.

La otredad durante todo el S. XX consistirá entonces en ubicar a las sociedades no europeas, europeisadas en algún tipo de representación del pasado. El estado-nación y la ciudadanía serán las expresiones de la conducción de las sociedades al ideal de que toda sociedad habita y deben habitar de forma uniforme el mismo tiempo del progreso. Todas las sociedades que no moran este tiempo forman parte de un grupo humano con retraso. Es esa una de las continuidades de las violencias raciales, el locus binario, que oculta esta nueva noción de tiempo: la minorización de los pueblos. Estos términos de violencia y racialización provienen del orden colonial. Es decir, el discurso de la nación del nuevo tiempo del progreso moderno ensombrece la notoriedad de las continuidades entre las formaciones coloniales y las modernas.

Por ello Rufer retoma el concepto de modernidad colonial, y a través de este repone, el tiempo como categoría política. En base a ello, busco develar operaciones en correspondencia con la nación imaginada que han permitido la articulación de espacios de poder en los que se teje y toma sentido un saber y se despliegan unas prácticas.

con futuro abierto, que se desarrollan y se diferencian notoriamente de su pasado son sociedades de la historia. Las sociedades que tienen un eterno presente o viven en él son sociedades sin historia, son de la antropología. 


\subsection{Otrificación nacional}

Como se ha expuesto, la formación de la nación está imbricada con la adherencia al nosotros y el distanciamiento de otros, y que esas adherencias y distanciamientos son construcciones políticas e históricas atravesadas por nociones de tiempo. Anderson (2007) muestra que toda nación se muestra a sí misma heredera de un pasado inmemorial e inmaterial. Imagina, dice Ospina (1996) un arraigo que ubica su eclosión en un tiempo difuso, inapreciable y antiguo cuya biografía se rememora desligada de los Estados que las hicieron nacer. Por ello, plantea Ospina, toda nación es una creación histórica de los estados en una época de expansión de un capitalismo que surge, en parte, gracias a las condiciones adelantadas del Estado absolutista. En este estilo de nacionalismo entonces, es común encontrar un esfuerzo desde el Estado moderno por reclamar para sí el monopolio sobre la legitimidad de los elementos que aglutinan a la nación

Las naciones, los nacionalismos y los Estados nación son creaciones históricas que no se reconocen como tales porque su capacidad de aglutinar y definir las pertenencias nacionales no radica allí, sino en su capacidad de convertir "el azar en destino" (Anderson, 2007, p. 29). De ahí proviene la idea de "comunidad imaginada". Ésta reside en un acto performativo que es al unísono "mágico". "Por un lado porque históricamente transmutó los sentidos de pertenencia desde las comunidades aferradas a diferentes sistemas religiosos, hacia otros anclados en significados seculares como un pasado y una cultura comunes; pero también y sobre todo porque ubicó el desenvolvimiento de ese pasado y las características formativas de esa cultura como dotadas de un telos, un 'espacio de espera' que es siempre la culminación de un desarrollo político único (universal, secular, liberal)" (Rufer, 2004 :773).

En este acto performativo y mágico, el nacionalismo oficial imagina un pasado y una cultura común, unas características formativas de la cultura dotadas de un telos que convierte el azar en destino. Esta imaginación está sostenida por una política de homología que es también regulatoria y racial. Según Segato (2007), la nación inventa, al interior de su espacio particular, sus propias estructuras de significación racial inmersas en la imaginación de la comunidad nacional. Y, al condensar la línea histórica del tiempo en un "nosotros" materializan un signo racial/racializante en el cuerpo del "otro" de la nación. Toda nación, entonces, tiene su propio proceso de producción de alteridad. El carácter de identidad es dependiente de las culturas nacionales e impacta en la percepción de la raza

"y de la diferencia en general, modifica lo que se ve, impregna el campo de lo que creemos que es objetivamente 'visible'. (...) Lo que intento enfatizar (...) es que raza es signo y, como tal, depende de contextos definidos y delimitados para obtener significación, definida como aquello que es socialmente relevante. Estos contextos están localizados y profundamente afectados por los procesos históricos de cada nación. (...) cuando el sistema (el contexto), primero colonial y más tarde nacional (...), se construye, y en el mismo acto de su emergencia e instauración idiosincrásica, como efecto de este movimiento de 
emergencia, el sistema crea sus otros significativos en su interior: todo estado-nacional o colonial- es otrificador, alterofílico y alterofóbico simultáneamente. Se vale de la instalación de sus otros para entronizarse, y cualquier proceso político debe ser comprendido a partir de ese proceso vertical de gestación del conjunto entero y del arrinconamiento de las identidades, de ahora en adelante consideradas 'residuales' o 'periféricas' de la nación” (Segato, 2007: 136-37-38). [El énfasis es mío]

Al concepto de nación como objeto de pertenencia de Anderson (2007), Segato (2007) agrega que la nación es un espacio particular que construye e inventa históricamente sus propias estructuras de significación racial (otrificación), y son estas estructuras las que organizan la pertenencia a la nación. Para esta autora la nación es objeto de identificación. Sugiero aquí, que esta identificación, al estar atravesada de un uso específico del pasado y de una invención local de la estructura de significación racial, guarda el signo de la raza y el tiempo que son parte de la experiencia localizada, es decir inserta en un desarrollo históricos específico.

Entonces, la nación oficial es una construcción histórica articulada como una comunidad imaginada dotada de un telos. La imaginación es un acto performativo en la medida que hace un uso político del pasado para organizar narrativas de tiempo que aglutinan la historia de las comunidades en un pasado, un presente, una cultura, una lengua, un raza, una religión común. $Y$ es ese uso político del pasado el que ubica un telos-destino en ese pasado y en esa cultura común que aglutina la historia de la comunidad y la embarca en la búsqueda de la culminación de un desarrolló político único. El acto performativo a la vez es otrificador, produce alteridades arrinconándolas a través de una representación homologadora del pasado que delimita fronteras entre el nosotros/otros y lo nuevo/viejo, materializando así, en el cuerpo del otro de la nación, el signo de la raza y el tiempo.

\subsection{Nación, raza y utopía nacionalista}

Anderson (2007) sugiere que "el nacionalismo piensa en términos de los destinos históricos, mientras que el racismo sueña con contaminaciones eternas (...)” (p. 210). La imbricación entre raza y nación se manifiesta en ese carácter cerrado y abierto que presenta la nación como "fatalidad histórica y como comunidad imaginada mediante la lengua (...)" (p.205). Es abierta en la medida en que a ésta se puede acceder si se comparte o conoce la lengua. Pero es cerrada porque es sentida con "amor desinteresado" (p. 202) por sus correligionarios y solo tiene un significado afectivo para éstos. Ese afecto "desinteresado", "puro" a lo nuestro-nosotros es a la vez un rechazo a lo otro, lo ajeno, lo que no pertenece. Mientras que el racismo evade la contaminación con otras razas, el nacionalismo evade lo foráneo, para el nacionalismo "los pasados se respetan, las camaraderías se imaginan y los futuros se sueñan" (p. 217). Se ha manifestado anteriormente que ésta delimitación entre lo propio y lo ajeno para este autor está contenida en un tiempo homogéneo simultáneo y

vacío, está moldeada por el tiempo moderno, y toda oposición a esta temporalidad será interpretada como de tiempo premoderno, como un remanente del pasado. 
Partha Chatterjee (2008) considera que el debate sobre raza/nación/tiempo que Anderson abre en Comunidades imaginadas, es continuado más tarde en The Spectre of Comparisons. En este trabajo, manifiesta Chatterjee, Anderson distingue entre nacionalismo y políticas de la etnicidad, identificado dos formas de series producidas por "el imaginario modero de la comunidad": series de adscripción abierta y de adscripción cerrada. Las series abiertas, dice Chatterjee estarían plasmados en los "conceptos universales característicos del pensamiento social moderno: naciones, ciudadanos, revolucionarios, burócratas, trabajadores, intelectuales, etc [y son] típicamente imaginadas y narradas por medio de los instrumentos clásicos del "capitalismo de imprenta' (...)" (p. 60). Las series cerradas en cambio operan como categorías que clasifican al individuo como uno o como cero, sin posibilidad de tener una filiación parcial. Se es negro o no, indio o no, etc. Son categorizaciones limitadoras y son el fundamento para generar políticas de la etnicidad (p.61).

Chatterjee piensa que en esta distinción de Anderson solo se puede hacer factible la idea de una política común si se asume de antemano que hay un mundo "único en esencia" en el que el tiempo también se traduce en términos de espacio, lo que implicaría hablar de espacio-tiempo moderno y de una política que habita en un espacio-tiempo moderno homogéneo, simultaneo y vacío. Chatterjee critica esta postura aduciendo que solo nota un lado del espacio-tiempo moderno. Para este autor el tiempo homogéneo y vacío es imaginable más no habitable, pues el espacio-tiempo moderno es el tiempo utópico del capitalismo. Utópico porque no tiene lugar en ninguna parte. La nación existe dentro de un espacio moderno de tiempo heterotópico ${ }^{12}$, "disparmente denso" (2008, p.62). Además, el autor argumenta que no se puede hablar de una coexistencia entre un tiempo moderno y un tiempo premoderno sino de realidades muy heterogéneas y fragmentadas que no son supervivencias de pasados premodernos, sino el producto del encuentro con la modernidad.

Reparando en la descripción que Homi Bhabha hace sobre el lugar de la nación en el marco de la temporalidad, Chatterjee señala que la narrativa nacional no puede eludir la ambivalenia de dos temporalidades que permanentemente interactúan: el tiempo de la pedagogía nacional y el tiempo de la continua escenificación. En el primer plano temporal,

${ }^{12}$ El autor toma el concepto del filósofo Michael Foucault. Con el concepto heterotopía Foucault pone atención en la indeterminación y la multifuncionalidad de los espacios de la cultura en la modernidad. Los espacios multiformes los son porque en estos se manifiesta la tensión con la mismidad y la alteridad en tanto que presenta la imposibilidad de fijar las identidades, pues sobre ellas hay un proceso continuo de resignificación. En esta sentido, la heterotopía da cuenta de una confluencia tanto de flujos nacionales con pretensiones homogenizantes como de los flujos híbridos que componen la cotidianidad y que escapan a esa imaginería, en esa medida, la dialéctica del espacio involucra, una dialéctica sobre el tiempo, que así como el espacio, es también múltiple. Foucault observa que heterotopía y heterocronía se relacionan y se disponen de forma relativamente compleja puesto que un espacio puede estar asociado a la acumulación de tiempo como a lo más fútil de éste. Sobre la presencia de esta relación entre tiempos y espacios en la imaginería nacional, Chatterjee ha observado que la comunidad imaginada es también una imaginación heterogénea que comprende espacio y tiempo. 
"el pueblo es objeto de una pedagogía nacional ya que se encuentra siempre en construcción, en un proceso de progreso histórico hacia un nunca culminado destino nacional." La nación homogénea en este sentido es una categoría pedagógica, una estrategia narrativa y un aparato de poder que educa masas para la ciudadanía. En el otro plano temporal se juega la identidad-unidad del pueblo, una identificación permanente con la nación que "debe ser continuamente significada, repetida y escenificada." (Chatterjee, 2008, p. 63).

Esa sensación de "destino histórico" del que habla Anderson para referirse al nacionalismo, está enmarcada en una concepción de tiempo homogéneo que es para Chatterjee una abstracción utópica. El sueño de los nacionalistas para este autor, es el del "tiempo utópico del capitalismo" en el que la construcción-imaginación ideal y vacía de la nación al oscilar en el tiempo heterogéneo receptaría contenidos diversos de la diversidad de la población integrándolos con su carácter específico a la serie abierta de ciudadanos nacionales. Por el contrario, para este autor, el carácter utópico de la imaginería nacional genera condiciones normalizadoras para tal integración.

Estas condiciones normalizadoras para la integración forman parte de esas formas particulares de adaptación de la modernidad exógena a la que me he referido anteriormente. Chatterjee señala que el Estado, basado en un modelo cuyos andamiajes los constituyen conceptos universalistas como ciudadanía, democracia, igualdad, entre otros, pretendió desarrollarse en sociedades poscoloniales descuidando los referentes autóctonos. Ello devendría en un largo desencuentro entre Estado y sociedad. Ello no quiere decir que la sociedad se viese sumida en un proceso histórico de confrontación entre política de élite y política subalterna. Más quiere decir que la realidad se sume en otras formas de dominio político que exigen la necesidad de la negociación entre un proyecto hegemónico de modernidad y las resistencias fragmentadas hacia dicho proyecto normalizador.

El reclamo nacionalista por la modernización y el progreso enmarcado en los conceptos universales y que dota la imaginación de la nación de un telos-destino en pos de su homogenización "es casi siempre una máscara para cubrir la perpetuación de las desigualdades." (Chatterjee, 2008, p. 83). Es en esta perpetuación donde se podría reponer una forma específica de lectura y definición de la raza al interior del espacio nacional, pues la crítica heterotopica al tiempo homogeneo pone de manifiesto, no el carácter consensual de la nación oficial, sino más bien la búsqueda utópica por centrar las definiciones de las diferencias en torno a un proyecto racial que imagina la nación oficial en el plano de una homogeneidad que camine hacia el progreso.

Si bien a Anderson se le reconoce, como expuse, haber notado el carácter ambivalente de la nación al plantear que éstas extienden y extravían sus orígenes en los mitos del tiempo (pasados inmemoriales y futuros ilimitados), y el haber sugerido que el nacionalismo sea entendido en relación a los sistemas culturales que lo precedieron, así como a los que se 
opuso, también se ha dado a notar que su noción sobre el racismo nacional como "ideología de clase" (Anderson, 2007, p. 201) pierde de vista precisamente que esa ambivalencia de la nación se replica con una particularidad que responde a la historia de cada nación, pues, "Si bien las nociones de mezcla, sangre y pureza ciertamente han marcado los discursos racistas, estos a menudo están vinculados mutuamente a través de una historia nacional y de clase." (Radcliffe y Westwood, 1999, p. 56).

Por ello, Homi Bhabha (2000) considera que es preciso retomar la tesis sobre la ambivalencia para entender a la nación en su "amplia y liminal imagen" (p. 211), como una forma de elaboración cultural con rostro de Jano. Es decir, una ambivalencia que se expresa en el mismo lenguaje que construye el discurso nacional. El rostro de Jano marca la hibridez de la nación, su valor de verdad, fija sentidos y valores. La localidad de la nación define fronteras con rostro de Jano entre el dentro y el fuera, entre el otro y el nosotros. Bhabha sugiere que al mirar la ambivalencia, al mirar el rostro de Jano de la nación se logra comprender la relación tensa y compleja de alterización del espacio nacional. "El otro no está nunca afuera o más allá de nosotros; emerge necesariamente en el discurso cultural, cuando pensamos que hablamos más íntimamente y autóctonamente entre nosotros." (p. 216). Para este autor, entonces, tanto las minorías marginalizadas como grupos hegemónicos intervienen en la unificación y totalización de los mitos de la cultura nacional.

Sarah Radcliffe y Sallie Westwood (1999) retoman para América Latina esta insistencia en la tesis de la ambivalencia para pensar el impacto del racismo en la descentralización de la narrativa nacional, la tensión entre influencias de identificaciones etnicistas tradicionales y aspiraciones modernizantes y seculares. Estas aspiraciones modernizantes y seculares pueden ser revisadas, como mencioné, en la tensión entre grupos hegemónicos y minorías marginalizadas, pero también, añado, entre grupos hegemónicos con otros grupos hegemónicos que se disputan la definición legítima sobre la narrativa nacional. En ambos casos, para pensar la problemática de la raza en el espacio nacional, a la noción de nación como objeto de pertenencia de Anderson (2007) y de nación como objeto de identificación-otrificación (Segato, 2007), agrego la noción de nación como objeto descentrado de las autoras. El descentramiento configura a la nación como un terreno de disputa y lucha donde se despliegan múltiples racismos que se constituyen por la articulación de género, sexualidad, sexo, raza y clase ${ }^{13}$.

Recuperando a Balibar, estas autoras piensan que la tensión y la ambivalencia de la nación, ese rostro de Jano que la compone, hilaron una narrativa cuya forma se articula alrededor de una identificación etnicista que fue producida para negar la etnicidad real y crear una "etnicidad ficticia” (Balibar, 1990, en, Radcliffe y Westwood, 1999, p. 58). Dicha ficción

\footnotetext{
${ }^{13}$ Puesto que no realizaré un estudio de interseccionalidad no trabajo la relación género, raza, sexo y sexualidad en relación al problema de esta tesis. Sin embargo, considero que es un trabajo que urge ensayar.
} 
está "vinculada al nacimiento del estado nacional y al poder de la conquista. En el lenguaje de la 'democracia racial' y el mestizaje, la hibridez es la norma y las etnicidades exclusivas son arcaicas, mientras el proyecto moderno en América Latina está asociado con la identidad mestiza, pero la lengua de lo blanco pervive (...)" (Radcliffe y Westwood, 1999, p. 58). En la etnicidad ficticia y la nación descentrada como conceptos no se baraja lo unitario de los procesos de alterización racializantes, sino más bien buscan reponer la bifurcación que está en juego en los procesos de racialización ${ }^{14}$. Además, los procesos de racialización al interior de la nación, simultáneamente, pueden ser utilizados tanto para marginar como para cooptar diferentes etnicidades. Ello, según las autoras, manifiesta que al interior del espacio nacional, los racismos expresan un carácter contingente y dinámico. Se trata entonces de captar, en la heterotopía de las narrativas nacionales, el carácter ambivalente de la nación y las contingencias y dinámicas raciales y racializantes de sus proyectos.

\subsection{Tiempo, usos del pasado e identidad}

Pensar la narrativa nacional como forma de construcción moderna de un "nosotros", es decir como objeto de pertenencia (Anderson, 2007), y como objeto de identificación para la producción de alteridades (Segato, 2007) en la que se expresa el carácter dinámico y contingente de los racismos en la nación descentrada (Radcliffe y Westwood, 1999) coloca justo en medio de dicha narrativa la disputa por la definición de las identidades nacionales. La estructura ambivalente de la nación, su rostro de Jano (Bhabha, 2000) pone de manifiesto que la construcción de el "nosotros" y el "otros" se halla inmersa en unas relaciones de poder que se encuentran tensadas por un juego de tiempos en el que se gestan esas identidades. La definición del "nosotros" y el "otros" es una producción de límites y fronteras entre lo que pertenece al "pasado" y al "presente". Esta producción de genealogías al interior del espacio nacional es una producción en tiempo heterogéneo (Chatterjee, 2008) en el que las identidades se tensan entre lo utópico y lo heterotópico. La producción de identidades conlleva una estructuración de temporalidades, y cada estructuración produce sus propios sujetos (nosotros-otros) y sus propias narrativas.

En este sentido entonces identificarse y otrificar implica un desafío heterogéneo a las categorías temporales de la operación historiográfica. En una reflexión sobre tales desafíos, Sergio Visacovsky (2007) plantea que la separación a través de la definición del "pasado" con el "presente", que constituye la operación clasificatoria fundante de la historiografía, es interpelada por los usos particulares del tiempo, es decir por las temporalidades, por "modos no expertos de organizar la experiencia" (p. 279) que optan por comienzos y trayectorias no oficiales, distintas a las expertas para periodizar las escenas que componen

\footnotetext{
${ }^{14} \mathrm{Al}$ respecto de la bifurcación y la producción de alteridades, señalan las autoras que en América Latina, mientras que los indígenas fueron construidos como los otros en relación a la cultura y el color de la piel, la esclavitud del pueblo africano condujo a una diferenciación cultural basadas en discursos seudocientíficos del racismo que explicaba las funciones del cuerpo en relación con la capacidad productiva (1990, p. 60).
} 
sus narrativas. En estas composiciones los eventos seleccionados, señala el autor, no son ordenados exclusivamente a partir de las cronologías, se puede recurrir a "marcadores temporales (como los adverbios 'antes' o 'después') relacionados con alguna situación, suceso o momento específico (tal guerra, tal revolución, tal gobierno) y ubicar los acontecimientos en posiciones temporales de mayor o menos proximidad respecto de otros considerados significativos y determinantes del orden secuencial." (p. 280). En los usos no especializados de la temporalidad la definición historiográfica sobre lo que es "pasado" y "presente" es difusa.

Estas "concepciones nativas" de la temporalidad según Visacovsky, pugnan por ser parte constitutiva del objeto histórico a través de la "constitución de los hechos" y no solo de su "relato" (p. 281). Los usos de las distancias temporales, en la pugna por la constitución del objeto histórico reflejan la relevancia social que dicha constitución tiene en la construcción de identidad, pues el autor entiende que en esta dinámica, el pasado no solo evoca lejanía o proximidad, "el pasado existe como fuerza socia actual (...) encarnada en cada contexto contemporáneo de acción, modelándolo, vehiculizando ciertas interpretaciones en desmedro de otras" (Visacovsky, 2007, p. 281) que a su vez pasan a ser determinantes para las acciones del futuro. Como "fuerza viva", el pasado es relevante socialmente "porque proporciona fundamentos a las pretensiones de identidad, legitimidad y conflicto en las condiciones presentes." (Visacovsky, 2005, p. 299).

Las "concepciones nativas" a la vez que le disputan a la historiografía la constitución del objeto histórico y son útiles para la definición de identidades, también dirimen posiciones, sirven para legitimar puntos de vista, personas e instituciones en detrimento de otras, proyectan líneas de acción, luchas, resistencias, producción de material textual, fílmico, gráfico o de otra índole, definen la oposición entre pasado y presente, ayudan a delinear órdenes morales, pasados emblemáticos y ejemplares para el presente, envisten las imágenes del pasado de una historia política o un sentido político de la historia. Todo ello es para Visacovsky constitutivo del "nosotros" y el "otros". Las "concepciones nativas" son producciones sociales de la temporalidad en las que las experiencias son ordenadas en esquemas de clasificación temporal socialmente construidos que representan y al mismo tiempo construyen las acciones sociales (Visacovsky, 2005).

Si partimos, entonces, de que los usos sociales de las distancias temporales son formas de re-significación del pasado y el presente, a estas clasificaciones temporales "nativas", se las puede entender como "producciones de historia". Concepto que Rufer (2010b) recupera de David Cohen, la "producción de historia" busca poner de manifiesto las tenciones entre las distintas formas de administración del pasado, entendiendo que esta administración es un proceso heterogéneo y desigual en las disputas por la fijación y regulación sobre el pasado. Administrar, para este autor, implica una práctica oficial e institucional de gestión sobre el pasado y el presente, pero también anexa las apropiaciones sociales de distintas formas de 
ordenar, producir textos/narraciones/dispositivos y fijar la significación y el acceso a la significación de las narraciones sobre el pasado y el presente.

Este autor plantea que los diferentes actores que buscan la re-significación del pasado apelan a la re-significación de la nación. En este aspecto los usos sociales y oficiales que buscan legitimar y regular el pasado de la nación pueden ser entendidos como producción de historia. Estas producciones oficiales o no, no son tomadas desde este concepto como verdaderas o falsas o como faltas a la historia, sino como elementos que indican el carácter político intrínseco en las luchas por las interpretaciones del pasado.

\footnotetext{
"Producción de historia- como un marco de referencia que ensancha los sentidos convencionales de la historia y la historiografía- refiere a los modos de procesar el pasado en sociedades y contextos históricos de todo el mundo, y a las luchas por el control de voces $\mathrm{y}$ textos en innumerables espacios, las cuales animan estos procesos de conocimiento del pasado. Este campo de práctica-producción de historia- abarca desde las convenciones y paradigmas sobre la formación de conocimiento y textos históricos, hasta las sociologías que organizan los proyectos y eventos historizantes, incluyendo exhibiciones y conmemoraciones; comprende desde la estructuración de formas de conservación de registros [...] hasta la confrontación de modos y fuerzas que subyacen a la interpretación; desde la recepción social en el manejo y la respuesta a las presentaciones del conocimiento histórico, hasta la contenciones y luchas que evocan y producen textos y literatura histórica. Como concepto, producción de historia busca al mismo tiempo evadir y tener como telón de observación cuidadosa a los marcos de referencia y a los protocolos, a veces estrechos, que constituyen la práctica 'historiografía' y las líneas de la crítica y el debate historiográfico. (Cohen, 1996. En: Rufer, 2010b, p. 31).”
}

La producción de historia no refiere entones a la búsqueda de lo verdadero o falso, más bien refiere a la pretensión de verdad de los "usos nativos" de las distancias temporales, a la intención de afincarse en el terreno de la verdad, no precisamente para decir la verdad sino para hablar desde allí. Se trata de analizar los usos sociales de las distancias temporales sin desechar las contradicciones sino trabajar a través de ellas. Y al hacer inteligibles las contradicciones, develar cómo desde la pretensión de verdad "apelan a (y operan con) las categorías de tiempo, nación, historia nacional, sujeto colectivo, memoria común.” (Rufer, 2010b, p. 73).

La pretensión de verdad de los "usos nativos" de las distancias temporales en la "producción de historia" operan desde el presente donde se construyen las identidades. Si agregamos a ello el carácter utópico que compone la imaginería de la nación, es decir una expectativa de porvenir, un ideal de futuro o un futuro deseable, advertimos que futuro/pasado/presente confluyen en un momento dado. La pretensión de verdad en la producción de historia opera, entonces, en lo que Elizabeth Jelin (2012) denomina como "temporalidades complejas".

En un diálogo con Ricoeur, Koselleck, Huyssen, Connan y Rousso, Jelin plantea que todo proceso histórico está atravesado por la subjetividad humana que complejiza cualquier 
concepción de linealidad del tiempo. El tiempo histórico se vincula a líneas de acción y a seres humanos concretos que establecen de manera compleja los sentidos de la temporalidad. En estos sentidos construidos el presente contiene la experiencia pasada, es decir tienen que ver con lo que se define como lo memorable. Para esta investigadora, lo memorable se torna significativo en función del sentido que se le da en el presente. Lo memorable es lo que esos seres humanos concretos hacen con lo que rememoran y olvidan selectivamente, pues las narrativas sobre el pasado implican una selección de recuerdos y olvidos que resultan necesarios para la permanencia y efectividad de funcionamiento de sujetos individuales y colectivos. "Pero no hay un único tipo de olvido, sino una multiplicidad de situaciones en las cuales se manifiestan olvidos y silencios, con diversos usos y sentidos. (...) toda política de conservación y de memoria, al seleccionar huellas para preservar, conservar o conmemorar, tiene implícita una voluntad de olvido." (Jelin, 2012, p. 62-63). El pasado, esos hechos y acontecimientos que cobran sentido en su enlace con el presente, en el acto de rememorar selectivamente, y también de olvidar selectivamente, tienen dentro de sí una perspectiva de futuro. El presente contiene la experiencia pasada y la elabora en función de una expectativa futura, en función de un futuro deseable. Todo presente incluye un pasado y una expectativa de futuro.

El pasado es un pasado que se expande o se retrae según las vivencias personales o colectivas que se incorporen a su interpretación y a los sentidos, intereses e intenciones que contengan sus usos. Los procesos de significación subjetivos comprenden una complejidad en la que los sujetos de acción se orientan y desorientan en tramas que conjugan diversas aprehensiones e idealizaciones de pasados y futuros "en un presente que se tiene que acercar y alejar simultáneamente de esos pasados recogidos en los espacios de experiencia y de los futuros incorporados en horizontes de expectativas." (Jelin, 2012, p. 47).

Cuando se establecen distancias entre pasado y presente, Según Jelin, éstas producen interpretaciones sobre el pasado que pasan a ocupar un lugar en los debates culturales y políticos y, además, a ser elementos clave en la construcción de identidades, puesto que la posibilidad de activar el pasado en el presente e incorporarlo en el horizonte de expectativas define la identidad y la oportunidad de su continuidad en el tiempo. Las identidades se ligan a un sentido de pertenencia que se juega su mismidad en su capacidad de sostenerse a lo largo del tiempo. Recordar el pasado (y hacer uso de éste) sostiene la identidad. Identidad y rememoración constituyen la subjetividad sin desatarse, pues, como señala la autora, no son algo que se extravía o se encuentra sino algo con lo que se trabaja, no algo sobre lo que se piensa sino con lo que se piensa y se hace, con lo que se constituye o deshace, con lo que se genera adherencias o rechazos. ${ }^{15}$

\footnotetext{
${ }^{15}$ A esta tesis la autora agrega que esta "relaciones de mutua constitución implica un vaivén: para fijar ciertos parámetros de identidad (nacional, de género, política o de otro tipo), el sujeto selecciona, ciertos hitos, ciertas memorias que lo ponen en relación con 'otros/as'. Estos parámetros, que implican al mismo
} 
La pretensión de verdad de los "usos nativos" de las distancias temporales construidas en temporalidades complejas en la "producción de historia" que operan desde el presente que incorpora un pasado (como hechos y acontecimientos que implican rememoraciones y olvidos selectivos) y un futuro (como horizonte de expectativas, futuros ideales y deseables), define las identidades en mismidades y oposiciones que se juegan sus límites en su capacidad de sostenibilidad en el tiempo, están entonces enmarcadas en cuadros ${ }^{16}$ sociales que posibilitan el sentido del olvido, el recuerdo y la constitución de identidades propias e identificaciones de 'otros' o producciones de alteridad u otrificaciones (a usanza de Segato).

\subsection{Instituciones del saber, campo de visibilidad y luchas por la representación}

Sustentado con Jelin, Rufer y Visacovsky he planteado que las concepciones nativas son un eje de importancia mayor en la formación de identidad de grupos y en oposición a 'otros'. Estos usos sociales de las distancias temporales pueden estar relacionados con la producción de lo que De Certeau llama "objetos de saber", y éstos a su vez con las disputas por la verdad sobre la nación moderna y sus sujetos. Los "sujetos de saber", a partir de sus concepciones nativas y la producción de historia disputan un lugar dentro de los saberes "instituidos", "legítimos" y "legitimados". Y lo hacen desde la posición social que ocupan como "sujetos de saber" que pertenecen a una "institución del saber". Desde allí discuten y producen sus "objetos de saber" y disputan un sentido sobre el pasado y la narrativa nacional. Ello implica además que dicha producción y disputa esté atravesada por una concepción de tiempo que tiene efectos directos sobre la diferenciación entre "sujetos de saber" y "objetos de saber", "nosotros" y "otros".

Empezaré planteando que por saber entiendo aquí a "todos los procedimientos y todos los efectos de conocimiento que un campo específico está dispuesto a aceptar en un momento dado $[\ldots]$ en efecto, no puede configurarse un elemento de saber si, por un lado, no está conforme a un conjunto de reglas y de constricciones propias de un cierto tipo de discurso científico en una época dada y si, por otro, no está dotado de los efectos de coerción típicos de lo que está validado como científico, o simplemente racional o comúnmente admitido"

tiempo resaltar algunos rasgos de identificación grupal con algunos y de diferenciación con 'otros/as' para definir los límites de la identidad, se convierten en marcos sociales para encuadrar las memorias." (Jelin, 2012, p. 58). Los marcos sociales, concepto que Jelin toma de Halbwachs, aluden a una visión de mundo que es animada por valores de una sociedad o grupos. El marco social en estos términos enfatiza en lo colectivo. Se hace el pasado con códigos culturales compartidos. Ello exige pensar que los marcos son históricos y por ello son cambiantes y contingentes. Entonces, para esta autora, la rememoración y el pasado, más que ser un recuerdo o algo dado, son una construcción que encuentra lugar en el marco. 
(Foucault 1994, III, p. 54-55, citado en Agamben, 2009, p.14). La legitimidad de los objetos de saber y la autoridad de los sujetos de saber en un campo específico, permite que ese estatuto de ciencia (que se acepta como ciencia) dispute el sentido sobre el saber con otros campos.

Ahora bien, De Certeau (1993) piensa que la formación de una institución del saber no está (y no puede estar) aislada de lo que suscita en el cuerpo social, pues lo que 'está' en el cuerpo social origina las prácticas de la institución. Las instituciones no son hechos incomunicados de lo social que se auto-producen ni se auto-re-producen. No surgen solas. Se producen en relación con lo social y en relación de producción de lo social. Se producen produciendo a una sociedad de la cual extrae y otorga sentidos. Al producir la sociedad en esta relación/producción de la sociedad organiza un saber sobre ella y lo expone a través de una forma propia, lo que quiere decir que al hacer inteligibles los objetos construye una realidad que es descrita a través de un "género literario propio: el relato" (De Certeau, 1993, p. 51). El saber es relato de la sociedad en la que emerge y produce al unísono.

Este relato es parte de un proceso científico que, según el autor, es un encuentro con 'el otro'. Tal encuentro es vehículo de la constitución de los objetos pensables. Para este autor el 'otro' en el saber histórico es un pasado, es lo muerto (que revive en el trabajo historiador) y una naturaleza (que es la historia en su conjunto). Para De Certeau la articulación naturaleza-cultura se da en la materialización de la obra histórica. El historiador tiene al tiempo como su materia de análisis y su objeto específico, y los trata según sus métodos y los transforma en historia. Gobierna la naturaleza, pero la gobierna para transformarla a través de un proceso científico que hace de una organización el foco de una metamorfosis promovida.

\footnotetext{
"Una obra 'histórica' participa del movimiento por el cual una sociedad modifica su relación con la naturaleza, convirtiendo lo 'natural' en utilitario [...] haciendo pasar una institución social de una condición a otra (por ejemplo, la iglesia convertida en museo). [...] El historiador logra la metamorfosis del ambiente a través de una serie de transformaciones que desplazan las fronteras de la topografía interna de la cultura. 'Civiliza' la naturaleza -lo que siempre ha querido decir que la 'coloniza' y la cambia. [...] Es 'científica', en historia y en otras partes, la operación que cambia el "medio" -o que hace de una organización [...] la condición y el lugar de una transformación. Se mueve, pues, en una sociedad, y en uno de sus puntos estratégicos: la articulación de la cultura con la naturaleza. En historia, establece un 'gobierno de la naturaleza' sobre un modo que concierne a la relación del presente con el pasado y en tanto que el pasado no es un 'dato', sino un producto." (De Certeau, 1993, p. $84,85)$.
}

"Es científica en historia y en otras partes" la operación que metamorfosea una organización -dice el autor-. Aquí entra en consonancia con lo que he planteado acerca de los usos no especializados del tiempo (Visacovsky, 2005) y la producción de historia 
(Rufer, 2010b) en la medida en que el sentido de la historia nacional es un objeto en litigio, una disputa por el pasado en tiempo heterogéneo. Por otro lado, coincide en el sentido en que tanto la operación científica como la producción de historia (que implica usos no especializados del tiempo ${ }^{17}$ ) pueden metamorfosear la naturaleza en razón de que las instituciones sociales y los objetos de saber son contingentes. Finalmente, agrego, si la historia "establece un 'gobierno de la naturaleza' sobre un modo que concierne a la relación del presente con el pasado y en tanto que el pasado no es un 'dato' sino un producto", este producto oscila en temporalidades complejas que incorporan, como dice Jelin, expectativas de futuro a las concepciones especializadas y no especializadas del pasado y a la producción de objetos de saber.

La tensión por el pasado entre usos legítimos y no especializados del tiempo puede comprender una disputa por el relato legítimo sobre el pasado que implica su especialización y espacialización. Siguiendo a Rufer y Segato, plantee que la espacialización (negación de la coetaneidad y usos opresivos del tiempo como operación política de génesis histórica) y la otrificación (producción de alteridad racializante nacional) son parte constitutiva de la producción del pasado en el presente de la nación en el que la mirada del observador es el punto de partida del tiempo moderno, es decir una mirada secular, naturalizada y nacional. Agrego ahora con De Certeau que el otro-pasado es producido como relato legítimo en el trabajo historiográfico, como objeto de saber cuya legitimidad le es disputada, y que en esa disputa se puede jugar la especialización del otropasado (le legitimidad del trabajo historiográfico) y su espacialización (la producción de alteridad). La especialización y la espacialización del pasado pueden comprender al trabajo historiográfico legítimo como a los usos no especializados del tiempo que gocen de una legitimidad científica que provenga de otra racionalidad o 'campo de visibilidad', pues como he planteado, los "usos nativos" de las distancias temporales construidas en temporalidades complejas en la "producción de historia" contienen una pretensión de verdad. La tensión por el sentido del pasado conlleva una disputa por la especialización y la espacialización del relato legítimo del pasado.

\footnotetext{
${ }^{17}$ No sugiero aquí que los usos nativos de tiempo y la operación historiográfica sean lo mismo. Lo que sostengo es que si bien en el caso específico de saberes legitimados como científicos responden a reglas y efectos de coerción, éstos pueden evocar concepciones legitimas de la temporalidad así como estar atravesados por concepciones nuevas de tiempo (ajenas al campo historiográfico, provenientes de otros campos o de intereses políticos o sustanciales para la identidad de grupo) que acompañan la producción de objetos de saber y la disputa por el sentido del pasado. También la adopción de concepciones de tiempo, así como el préstamo de conceptos entre disciplinas y los usos sociales de las distancias temporales, pueden evocar formas legítimas de concebir el tiempo para reafirmarlas, rechazarlas o legitimarse en éstas. Inclusos, estos actos (reafirmación, legitimación, rechazo) podrían estar presentes al unísono. La disputa heterogénea por el tiempo comprende entonces, de formas complejas a la práctica historiográfica, la crítica a la esta práctica y los usos sociales del tiempo: comprende esferas de sentido que permiten concepciones de tiempo.
} 
Ahora bien, si la historia se tensa con usos no especializados del tiempo, si se tensa por temporalidades complejas, el encuentro con el otro es también un encuentro con un límite, entendido éste como las posibilidades de conocimiento respecto del pasado y la historia.

Las condiciones del límite se establecen por lo que Rafael Polo (2010) denomina 'campo de visibilidad' u 'horizonte de visibilidad'. Para este autor, el campo de visibilidad se ensambla a partir de la identificación y definición de objetos de conocimiento que surgen al interior de un régimen de pensamiento y de identificación con el que se dota de sentido a las prácticas sociales. La dotación de sentido es posible porque los enunciados objetivan lo visible y lo que se puede enunciar. Por ello, dice Polo, "no hay mundo histórico fuera de estos enunciados que lo hacen visible". (p. 18-19). Los objetos de saber se encuentran siempre en disputa por la legitimidad del campo de lo visible. Los objetos de saber emergen de esta disputa, surgen como ruptura con un campo de visibilidad hegemónico. La disputa permite que un objeto de saber sea nombrado, visualizado y producido a través de un objeto de saber nuevo que pasa a ocupar el lugar central del campo de visibilidad.

El campo de visibilidad entonces es un campo social y conceptual en el que los conceptos producidos operan como vehículos de visibilidad y aprehensión de un objeto para hacerlo inteligible en la medida que "abre un mundo de percepciones y contribuye a construir la estructura del mundo que nombran." (Polo, 2010, p. 28). Se trata de un campo epistemológico y el límite se da por las condiciones desde las que problematiza los conceptos que hace surgir. Es decir que el campo esboza las posibilidades para hacer inteligibles los objetos y ello depende de la actualidad del grado de desarrollo teórico y técnico del saber. La posibilidad de pensar un objeto depende de un campo epistemológico ${ }^{18}$ que plantea sus reglas de constitución, inteligibilidad y aprehensión de los objetos que objetiva y delimita según estas reglas. La delimitación implica producción y exclusión de objetos puesto que “La 'razón' científica está indisolublemente unida a la

\footnotetext{
${ }^{18}$ Se puede decir con Koselleck que el horizonte de visibilidad que abre a su vez el horizonte de expectativas halla su apertura en la medida en que el lenguaje de la institución del saber se organiza como una teoría y modelo de explicación de lo real. La teoría se especializa en la medida en que articula el caos fenoménico de un problema que aborda. Al articular lo real entra en debate con su tiempo. Al hacerlo, como lo señala Polo, no es mero reflejo; lo real es construcción, y la teoría ayuda a nombrar esa construcción del mundo en la medida que lo nombra y produce. La teoría, en tanto que no es intuición ni se desconecta de lo real, procura, mediante el lenguaje teoría dialogar con lo real. Es allí donde Koselleck ubica la importancia que tiene el concepto para la teoría y la historia, pues, esta ampliación de expectativas se debe a dos particularidades de la producción de conceptos: 1) El concepto es un hecho y un indicador de algo que se sitúa más allá de la lengua, permite pensar una realidad histórica y efectuar acciones concretas sobre ésta, instaura formas de comportamiento y actuación junto con reglas jurídicas y condiciones económicas que pueden ser pensadas a partir de la existencia del concepto que se relaciona con la realidad que quiere comprender (Koselleck, 2009, p. 77); 2) las palabras-concepto "adquieren significación y poder por [lo que Bourdieu llama] ritos de institución, [que son un] mecanismos social de regulación de los discursos, en los que son pronunciados y al interior de los cuales adquieren legitimidad. Los ritos de institución son mecanismos de objetivación y de invención, como de naturalización, de la repartición de lo sensible, [...] producen y afirman las divisiones del mundo social." (Polo, 2010, p. 28).
} 
realidad que encuentra a su sombra y a su otro en el momento en que los excluye." (De Certeau, 1993, p. 56).

El campo de visibilidad y sus objetos de saber, para Polo y De Certeau, se encuentran en permanente disputa porque están ligados a los modos de construcción civilizatoria de cada sociedad que comprenden producción de saber, identidad de grupo y construcción de un 'otro'. Y allí, en la construcción civilizatoria que comprende identidad e identificación, es donde se pone en juego una lucha por la representación que es una lucha por el dominio del campo de visibilidad, por el "monopolio respecto al poder de hacer ver y hacer creer, hacer conocer y hacer reconocer, imponer una visión legítima de las divisiones del mundo social a través de principios de división que, cuando se imponen al conjunto de un grupo, constituyen el sentido y el consenso sobre el sentido y, en particular, sobre la identidad y unidad que hace efectiva la realidad de la unidad e identidad de ese grupo." (Bourdieu, 2001, p. 88).

En este mismo sentido De Certeau plantea que "El lugar dejado en blanco u oculto por el análisis que exageraba la relación de un sujeto individual con su objeto, es nada menos que una institución del saber. Esta institución señala el origen de las 'ciencias' modernas [que] está siempre ligado a la creación de grupos [...]" (De Certeau, 1993, p. 71). Así como los usos del pasado y las disputas por el sentido sobre el pasado son constitutivas de procesos de identificación y la construcción del otro, la formación de instituciones del saber conlleva una lucha constante por el campo de visibilidad, envuelve principios de divisiones del mundo social a través de principios de división que se imponen y hacen efectiva una unidad e identidad que está en la génesis de las ciencias modernas.

En la disputa por el dominio del campo de visibilidad, las instituciones de saber se juegan su capacidad - reconocida institucional y socialmente- de representar, de naturalizar, de consagrar diferencias, de "instituir", es decir, de asignar una esencia, una competencia, es imponer un derecho de ser que es un deber ser (o un deber de ser). Es significar a alguien a lo que es y significarle que tiene que conducirse consecuentemente a cómo se le ha significado. El indicativo es en este caso un imperativo [...] Instituir, dar una definición social, una identidad, es también imponer límites" (Bourdieu, 2001, p.81).

Instituir como acto es también designar invistiendo, lo que es proporcionar reconocimientos lingüísticos. La investidura

"consiste en sancionar y santificar haciendo conocer y reconocer una diferencia (preexistente o no), haciendo existir en tato que diferencia social, conocida y reconocida por el agente investido y por los demás. (...) la 
eficacia simbólica de los ritos de institución [es el] poder de actuar sobre lo real actuando sobre la representación de lo real. (...) porque al mismo tiempo transforma la representación que la persona se hace de ella misma y los comportamientos que se cree obligada a adoptar para ajustarse a esa representación. (...) La institución es un acto de magia social que puede crear la diferencia ex nihilo, lo que es el caso más frecuente, explotar en alguna medida diferencias preexistentes [...] es un $<<$ delirio fundado $>>$, un acto de fuerza simbólica pero cun fundamento in re. Las distinciones socialmente más eficaces son las que aparentan fundarse en diferencias objetivas (pienso, por ejemplo, en la noción de $<<$ frontera natural $>>$ ). (Bourdieu, 2001:80-81).

Instituir es entonces asignar esencias a través de la magia performativa de unos actos de institución capaces de producir, propagar, mantener y repetir mediante la mantención del habitus lingüístico, el sentido objetivo que domina en la circulación lingüística del espacio social. Encuentro aquí un doble acto performativo: por un lado el acto de magia performativa del telos-destino de la nación moderna, es decir la otrificación como espacialización nacional de la geopolítica del tiempo en la modernidad; por otro la asignación de esencias sociales en el saber científico.

Ahora bien, para Bourdieu la asignación de esencias, la capacidad de dar definiciones sociales que son identidades que imponen límites, comprende asignaciones de esencias corpóreas, o asignaciones de esencias que se vuelven cuerpo. Las disputas por el monopolio del campo de visibilidad son disputas por la definición del cuerpo, en términos de Foucault (1996, 2005, 2006, 2010a, 2010b), son disputas por la verdad del cuerpo. Para Foucault, en la producción de objetos de saber se halla el control del cuerpo como antesala del control político, puesto que el cuerpo está inmerso en unas relaciones de poder que producen saber sobre éste. Se trata de una anatomía política, "como conjunto de los elementos materiales y de las técnicas que sirven de armas, de relevos, de vías de comunicación y de puntos de apoyo a las relaciones de poder y de saber que cercan los cuerpos humanos y los dominan haciendo de ellos unos objetos de saber". (Foucault, 2010, p. 35).

En la disputa por el monopolio del campo de visibilidad hallamos ahora una práctica y un discurso político sobre la composición anatómica del cuerpo. Así como en la otrificación nacional encontramos la inscripción de una línea de tiempo del signo-raza en unos cuerpos específicos como sugiere Segato, también en la producción de objetos de saber encontramos una asignación de esencias que comporta búsqueda por la instalación de la "hexis corporal", de una "mitología política realizada, incorporada, vuelta disposición permanente, manera perdurable de estar, de hablar, de caminar, $y$, por ende, de sentir y de pensar." (Bourdieu, 1991, p.113). 
La emergencia de instituciones del saber, entonces, se vincula en la modernidad con la formación de la identidad de grupo. Esa articulación entre identidad y saber está atravesada por las luchas por el dominio y la representación de los objetos de saber, una lucha por el monopolio del campo de visibilidad. Además, la lucha por el campo de visibilidad comprende unos principios de división formadores de límites que marcan las distancias y las diferencias de grupos. Ello puede ser entendido como un juego de identificación en el que el sujeto de saber, una "voz autorizada" como la denomina Bourdieu (2001), se identifica y constituye en relación al límite con el "otro" producido como "otro-pasado" sujeto-objeto de saber especializado, y éste a su vez como "otro-cuerpo-espacializado" en un tiempo "otro" o un tiempo "propio", ya sea este un tiempo pasado, fututo o presente. Vemos entonces, que el juego de identificación implica estructuración de saber y estructuración de tiempo.

Siguiendo las tesis de las distintas posturas que he citado aquí sobre el nudo problemático entre raza, modernidad, tiempo/temporalidad, instituciones del saber, y nación, encuentro que esta complejidad fenoménica se anuda al cuerpo, entendido éste como producto social e histórico. El cuerpo como raza-signo. El cuerpo inmerso en una geopolítica del tiempo y en temporalidades complejas. El cuerpo como una somato-política en la producción de saber, como vector de los procedimientos y efectos de conocimiento que los campos de visibilidad aceptan y disputan, como vector del conjunto de reglas y de constricciones y de coerción que le son propias a los discursos científicos, el cuerpo como vector para la validación del saber científico. El cuerpo otrificado por las grandes cronosofías, vuelto el "otro" del tiempo pasado, abstraído a esta dinámica a través de las categorías e instrumentos científicos y sus relatos específicos. El cuerpo en medio de la tensión de los usos especializados y los usos sociales no especializados de las distancias temporales. En suma, el cuerpo como materialización de la imaginería performativa y mágica de la nación moderna (tiempo, temporalidad, raza, modernidad) y de las taxonomías del saber en las prácticas de la producción de historia y de la conformación y práctica de las instituciones del saber y sus relatos. 
CAPÍTULO 3 


\section{Capítulo 3}

\subsection{El evolucionismo, el ambiente, la biología, la raza, la nación y la historia: una comparación entre países}

Referirse a la eugenesia en América Latina conduce a notar un esfuerzo mayúsculo de varias disciplinas (antropología, medicina, biología, psiquiatría, neurología, entre otras) por definir categorías que permitan solucionar las problemáticas que se desprenden de la relación entre raza, degeneración y nación. La definición de estas categorías es parte de las preocupaciones médicas desde mucho antes que las tesis de Galton ingresen y se extiendan por el continente con la fuerza con la que lo hicieron desde la segunda década del siglo XX, pues son categorías anexas a los procesos otrificadores de la nación. La definición de los objetos de saber de la medicina guarda vínculos con los proyectos otrificadores de la nación.

Esto quiere decir que tales proyectos comprendieron un esfuerzo por hacer del indio un objeto inteligible y esa aprehensión está concatenada con una forma de imaginación de la nación, pues la construcción de la alteridad en los márgenes del campo científico médico, en Ecuador y en otros países de América Latina, se vincula con proyectos de modernización y de disputa por la configuración simbólica del espacio nacional.

En la inauguración de la sala de teratología del Museo Nacional de México, en 1895, Frida Gorbach (2008) observa una intención de incorporar los postulados de la biología a las preocupaciones médicas, sobre todo a los estudios sobre monstruos. Ello con el fin de asegurarle un porvenir a la ciencia. La incorporación de los postulados de la biología se efectiviza en el espacio de un Museo Nacional que desde antes de la Independencia se había dedicado a la historia natural. Es así que la teratología se traslada de la medicina a la historia natural. Ya no solo responde preguntas sobre el cuerpo individual, también, sobre la transformación de las especies, y al ser objeto de la historia natural los monstruos pasan a tejer una historia vinculada al Museo Nacional.

La exhibición de un objeto científico en este caso ocurre en el espacio del museo, en ese "dispositivo de visualidad" privilegiado para efectuar la exposición de la identidad nacional como "construcción que se relata", que "fabrica y exhibe la continuidad cultural" de la nación (Barbero, s/p). De allí que el sentido de la exhibición de los monstruos en el Museo según Gorbach (2008) funcionara como la exhibición de un patriotismo. Los científicos mexicanos consideraban que habían conseguido hacer del monstruo un objeto de la ciencia, es decir que tenía clasificación positiva, esto es una definición de identidades y diferencias, definición de regularidades de tipo, de clase y género con enlazamientos secuenciales de causa y efecto. Y a la vez que la definición positiva establece límites estableciendo definiciones, dice ser la realidad misma. La definición positiva es la realidad, y la realidad es exhibida en un dispositivo de visualidad para la exposición de la identidad nacional 
como lo es el museo, organizado - dice Gorbach- como se quería organizara la nación (p. 151). Organizada, cabe reiterar, por definiciones y límites con precisión científica. Definir un objeto es un logro científico, y estos logros son celebrados como motivo de orgullo nacional y como forma de expresión de una identidad moderna.

A la par de la sala de teratología se abrían la sala de Anatomía comparada y otra de Antropología. En las salas de Anatomía Comparada y Antropología que fueron inauguradas a la par de la de Teratología, se exhibía el mismo orgullo patrio debido a que traían modernidad científica a un museo que hasta el momento había sido fundamentalmente taxonómico (Gorbach, 2008, p. 140). La modernidad llevada al museo se expresaba en la noción de cambio de los estudios biológicos que pasaron a convivir con el culto a la fijeza de los monumentos y con la descripción de las bondades médicas de las plantas exhibidas en la sala que exponía la riqueza natural de México.

La sala de Antropología, dice Gorbach, se encontraba frente a la de teratología, exponía fotografías que daban cuanta de la diversidad racial del país, esqueletos humanos fruto de excavaciones y cráneos y cuadros de observaciones referentes a la antropología criminal. Esta vecindad, según la autora, coloca a las salas en un "juego de espejos" en el que halla el segundo elemento de las preocupaciones médicas y científicas: la determinación del origen de la raza mexicana y la detección de la anomalía en la raza. Es así que los contenidos científicos de orgullo para la patria, y por tanto musealizables, cumplían con un rol que no giraba del todo alrededor "de la vida, sino de la nación y de la raza como su equivalente científico." (Gorbach, 2008, p. 138).

La definición de objetos científicos tenía una importancia elemental para la patria, permitía a la ciencia mexicana adquirir autonomía frente a las definiciones y clasificaciones europeas sobre la raza y el lugar de los pueblos en este país. Y la clasificación y definición científica de la raza es fundamental para la elaboración del relato nacional. Esto sucede no solo en México, también en Ecuador, y esa búsqueda se ve extendida a varios campos del saber. Por ejemplo, el movimiento "indigenista interamariano" trabajó en pos de establecer definiciones y clasificaciones científicas, políticas e identitarias para diferenciarse e incluso resguardarse de las definiciones y clasificaciones norteamericanas y europeas que colocaban a una comunidad imaginada interamericana en desventaja biológica (Prieto, 2010).

Por el momento, éstos médicos no han optado por ese horizonte de expectativas interamericano y la definición del objeto en Teratología, según Gorbach, al buscar una respuesta a la pregunta por el origen desde la biología y la antropología coloca al indio del lado de la patología al ubicar, en éste, una anomalía ligada no a la anormalidad de su origen sino a una anomalía de tipo histórica. 
Es así que en México de finales del siglo XIX, la ciencia moderna, como discurso, tuvo lugar a través del concepto de anomalía ligado al indio y también a la mujer. Es en este concepto donde encontró sentido la ciencia para la nación en la medida en que, a través de este concepto los médicos de finales del siglo XIX e inicios del XX canalizaron el estatus del empirismo, la pertinencia del darwinismo social y la existencia de la patología en una misma definición. Mientras que el darwinismo social a través de las concepciones de la teratología estableció complejos y ambiguos nexos entre indios y monstruos, la patología moderna tuvo lugar a través del concepto de histeria situado en el cuerpo de la mujer. "De ese manera, anudando la ciencia y la nación, la medicina moderna delinea los rasgos del sujeto moderno, un sujeto colonial, escindido entre la histeria y la monstruosidad, entre la civilización y la barbarie, anómalo como su propia modernidad. Así es como el monstruo y la histérica dibujan la imagen de la nación moderna." (Gorbach, 2007, p.10).

Indio y mujer comparten el fondo común de la anomalía moderna en una nación mexicana que se determina fisiológicamente, y en esa determinación requiere un Estado "que aparece no ya como el producto artificial de la libre elección de los individuos que le dieron origen, sino como un conjunto integrado de hombres que se comportan como un único individuo espiritual y corpóreo a la vez. La historia de una nación así no requiere de explicaciones complejas ya que estas responden ahora a las dinámicas ligadas a las necesidades de la especie. Por eso, para definir su particularidad (...) necesita (...) de una fisiología patológica dirigida precisamente a determinar las modificaciones primitivas de la propiedad fisiológica." (Gorbach, 2013, p.136).

Es decir, aquí la patología no solo es mental, es también patología de la especie, y al serlo es patología de la historia y de la nación. Ello muestra entonces para Gorbach (2007-2008-2013) que el conocimiento comprende una dimensión política en la que se refleja una relación compleja entre historia, ciencia y nación; tres conceptos que para la autora develan una de las formas en las que la modernidad construyó los vínculos entre naturaleza, política e historia, dando lugar a que en México de finales del siglo XIX se conformen concepciones de ciencia que tuvieron a la historia y la nación como actores de su producción.

La importancia que adopta la definición y clasificación de objetos científicos tanto para la lectura de la sociedad y la raza como para el establecimiento de puentes que anuden el relato científico con el relato de la nación en el caso que acabo de citar, comprendió, además, una discusión sobre las relaciones entre medio y organismo. Esta discusión, propia de la realidad mexicana de finales del siglo XIX, es muestra, como veremos a continuación, de un antecedente sobre un debate que tomaría otro vuelo y otras dimensiones tras la introducción de la teoría eugenésica en América Latina del siglo $\mathrm{XX}^{19}$.

\footnotetext{
${ }^{19}$ Gorbach dice que la teratología en México al preguntarse por si los monstruos constituían o no una raza se ubicaban más cerca de la postura de E. Geoffroy Saint-Hilarie que la de Lamarck. Al preocuparse por la naturaleza del desarrollo
} 
Como se puede apreciar, la producción de objetos científicos para la comprensión de la raza y la nación percibe en este punto una recepción sobre la Teoría de la evolución de Charles Robert Darwin. Esta teoría permitió a los médicos naturalistas abrir un área de discusión a finales del siglo XIX en México sobre la raza. La discusión se centró en dos teorías que se debatían sobre si el origen de las "razas americanas eran producto de un tronco común cuyo origen estaba en Europa o los hombres del Nuevo Mundo eran razas autóctonas de América." (Gorbach, 2008, p.144). La aplicación de Darwin no se detiene en la pregunta sobre el tronco común, se extiende como eje de comprensión de la sociedad.

La recepción de Darwin hacia 1890, según Argueta y Ruiz (2002) tiene una notable influencia lamarckiana. Para ambos autores es muy común en México de la época concebir al darwinismo como el resultado de la suma de Lamarck con la selección natural. Los médicos naturalistas le otorgan un papel, algo menos que secundario, a la aparición de las variaciones espontaneas que en Darwin son azarosas y por tanto su resultado adaptativo no puede preverse. Al desplazar el azar "se confundió la evolución con la adaptación, pues se consideraba que toda variación era adaptativa y todo nuevo carácter, adquirido y heredable." (Argueta y Ruiz, 2002, p. 339). La insistencia en la herencia de caracteres adquiridos se sustenta en la concepción de la evolución del filósofo, naturalista, antropólogo, psicólogo y sociólogo inglés Herbert Spencer.

Estos rasgos se repite en Bolivia. Y, según Robles y Caballero (2016), la discusión sobre ambiente haría de toda Latinoamérica (un continente que por su densidad demográfica y heterogeneidad racial fue muy sensible a la eugenesia) un espacio en el que se libraría una última batalla entre neolamarkismo y neodarwinismo antes y después de la Segunda Guerra Mundial (p. 55).

Argueta y Ruiz señalan que la divulgación sobre evolucionismo en Bolivia arranca no con Darwin, sino con la traducción del libro de Dumont Haeckel y la teoría de la evolución en Alemania en 1877. Ello en medio de un periodo dominado por los gobiernos conservadores y una Iglesia que tenía en su mando la educación básica. Conservadores e iglesia fueron los más fervientes opositores a las teorías de la evolución tanto de Haeckel como de Darwin en este país andino. En México, en cambio la restauración republicana y las Leyes de reforma de 1868 propiciaron un espacio para la polémica y la recepción de Darwin centrando el debate en cuanto a la adherencia o rechazo de la teoría en el ámbito científico, a diferencia de Bolivia cuyos opositores no eran científicos sino miembros de la Iglesia (p. 141).

embrionario se toma a E. Geoffroy Saint-Hilarie para plantear que el surgimiento de la especie no se ligaba con la selección natural, sino con un proceso de patología y degeneración pues la evolución era el resultado de los efectos directos y momentáneos del medio. Esa postura se distanciaba de Lamarck quien veía que la adaptación del organismo al medio ambiente tendía a la perfección, "el medio actuaba indirecta y gradualmente sobre el organismo adulto (...)" (Gorbach, 2013, p.142) lo que permitiría, por así decir, corregir cualquier anomalía. 
Una vez introducida la teoría de la evolución, los postulados de Darwin se extendieron más allá de las barreras disciplinares de la historia natural permeando las discusiones de la sociología, la filosofía y la política. Para Argueta y Ruiz este fue un fenómeno que se extendió en toda Latinoamérica. El hiato sobre Darwin fuera de las fronteras de las Ciencias Naturales permite mostrar, para estos autores, que en este continente, la discusión social sobre ambiente que mencionamos, tuvo un predominio sobre lo biológico (p. 342). De allí que el socialdarwinismo favoreciera posturas opuestas sobre la naturaleza del indígena entre socialdarwinistas anti-indígenas y socialdarwinistas pro-indígenas.

Mientras que en México, un país que tiene al "indígena patrimonial" como uno de los centros de su mitología nacional (Barbero, s/p), se discute sobre la superioridad o inferioridad del indígena, en Bolivia los intelectuales y políticos socialdarwinitas, cuyos trabajos se sustentaron en las ideas spencerianas para construir una visión negativa sobre la decadencia del indio, llegaron a ocupar los más altos puestos de las áreas de decisión dentro de la república incluyendo la presidencia de Bolivia. Es el caso de José Manuel Pando y Bautista Saavedra. Ello lleva a pensar a Argueta y Ruiz en un "spencerismo de estado" en Bolivia. Además, la influencia dominante del lamarckismo en cuanto a la adaptación y de Spencer en la herencia condujo en México y Bolivia a prever "en el mestizaje las posibilidades de una homogenización nacional. Algo similar debió de haber ocurrido en Perú, mientras que en Argentina y Uruguay, sí se plantearon e hicieron notables esfuerzos en la política del exterminio." (Argueta y Ruiz, 2002, p. 242).

Los usos políticos de Darwin en Ecuador fueron varios. Así lo muestran Elisa Sevilla y Ana Sevilla (2016) en un trabajo que analiza las apropiaciones del darwinismo por parte de liberales y conservadores entre la Revolución Liberal en 1895 y el fin del garcianismo en 1875, periodos marcados por el asesinato del Presidente García Moreno quien dominó la política ecuatoriana desde 1859 con la implantación de un modelo de formación del Estado al que se ha denominado como "modernidad católica" (Maiguashca, 1994. En: Sevilla y Sevilla, 2016, p. 249). Estos dos periodos constituyen en Ecuador dos momentos de intensificación de luchas ideológicas entre ambas posturas que giraron en torno del darwinismo y la evolución del ser humano y sus características particulares, la relación entre ciencia y religión para los liberales y las implicaciones que el darwinismo tuvo al abordar las ideas de política, libertad, progreso y moral.

A diferencia de México y Bolivia, en Ecuador el uso de Darwin no estaría marcado por la frontera entre científicos y no científicos miembros de la Iglesia. Científicos o no, el darwinismo es una herramienta de interpelación ideológica. Sevilla y Sevilla resaltan que en esta lucha ideológica el darwinismo es utilizado por ambos bandos como arma desacreditadora del rival. Si los liberales laicos acuden al darwinismo en defensa de los principios de soberanía popular y anticlerical, los obispos, lo hacen para delinear la imagen de "un enemigo liberal, masón, irracional e impío." (p. 250). 
La disputa ideológica ocurre en un contexto en el que los liberales pretenden abolir la constitución de 1869 y las formas de control de las poblaciones delegadas al disciplinamiento de la Iglesia basadas en el Concordato. García Moreno llega a considerar que el caos que vivía el Ecuador, tras la amenaza de invasión por parte del Perú y la división del país en cuatro gobiernos regionales, no se podía solucionar solo con la aplicación de leyes, era necesaria la aplicación del autoritarismo y el control moral de la Iglesia como únicos medios para subsanar la crisis. Es ese el poder que Moreno le otorga a la Iglesia con la firma del Concordato en 1866. Y es ese el poder que los liberales quieren abolir a partir de la separación de la Iglesia con el Estado y que finalmente lograrían tras el triunfo de Alfaro en 1895. Darwin en Ecuador de mediados y finales del siglo XIX se encuentra en medio de una batalla cultural, una disputa por la modernidad católica conservadora y la modernidad laica liberal del estado y la sociedad.

La teoría de la evolución más que defender las ideas de Darwin, que con mucha probabilidad no eran conocidas por ninguno de los dos bandos -aseguran Sevilla y Sevilla-, actúan como una defensa ideológica de su posición en el Estado. Los conservadores y obispos ven en el darwinismo las señales de un materialismo negativo presente en los liberales y que los acerca por ello a la secta masónica y pone a los liberales al lado de un ateísmo que ni los más radicales dan muestras de defender. Se acusa a los liberales de degradar al hombre al asegurar que desciende del mono negando la procedencia divina y su semejanza con Dios. Los conservadores defendieron que el darwinismo propiciaba la barbarie y el caos y que la civilización del Ecuador le correspondía a la Iglesia que ve en el hombre a un ser con alma, con razón y con moral a diferencia de las bestias de las que los liberales decían que descendía la humanidad. En la idea de la lucha por la supervivencia la Iglesia advirtió una defensa del asesinato y en el concepto de selección natural un abandono de la caridad y la compasión. Finalmente, los obispos asociaron al caos las ideas promovidas por el anarquismo, el comunismo, socialismo, liberalismo y el darwinismo.

Por su parte, en los liberales el evolucionismo se muestra como una ideología de progreso (una asociación que encontraremos aún presente en médicos y psiquiatras de mediados del siglo XX). En esto Ecuador guarda una similitud con Bolivia a razón de que la recepción del darwinismo en las esferas del Estado no suscitó una contienda entre científicos sino ante todo resistencia y defensa ideológica. Ello derivó en Ecuador en una tergiversación de las tesis de Darwin sobre ambiente y adaptación.

A diferencia de lo que pensaba Darwin, donde todas las especies están mejor o peor adaptadas a su ambiente, Huxley y López [este último medico liberal ecuatoriano] ven una escala donde el hombre es superior al mono. Estas mismas ideas de un evolucionismo teleológico están presentes en los argumentos de Felicísimo López. Los liberales en el Ecuador solieron tener esta visión progresista de la evolución como en otros lugares del mundo. (...) el darwinismo aparece como demostración del continuo perfeccionamiento de hombre, dentro de la idea de progreso y en contra de la idea de la caída, la degeneración del 
hombre y del pecado original, bases de la doctrina católica. (Sevilla y Sevilla, 2016, p. 259261).

Para los liberales, dicen Sevilla y Sevilla, un indicador de la cultura de un pueblo era el consumo de libros de Darwin, Herbert, Huxley, Tindall, Brain, Spencer, Haeckel, entre otros, autores en los que sustentan sus argumentos en defensa de las tesis sobre el ser humano como parte de una naturaleza, de una cadena evolutiva. Aquí, la justicia, la moral y las leyes son consensos sociales y no divinos. Los liberales encontraron en la defensa de la ciencia moderna una forma de contrarrestar el Dogma de la Iglesia que asimilada al Estado por el Concordato de 1866 y la modernidad católica tenía la potestad de someter a los fieles con el miedo y la disciplina represiva (p. 261).

Pero, es necesario mencionar que fue la defensa de un aspecto de la ciencia moderna ligado al evolucionismo, pues una defensa de la ciencia y el abogar por su desarrollo ya era considerada, desde tiempos de García Moreno, una forma de conducir al Estado por el sendero de la modernidad, por supuesto, como vimos, aunada ésta con la moral católica. Muestra del interés por la promoción de la ciencia durante el concordato es el desarrollo y el impulso de la física y la medicina con la construcción del Observatorio de Astronomía, la Escuela Politécnica Nacional, el Anfiteatro de la Universidad Central, el apoyo a las investigaciones médicas y quirúrgicas sobre las costumbres de la población, etc.

Ahora bien, al analizar el caso de Cuba colonial Verena Stolcke (2000-2009-2011a-2011b) describe un salto entre la organización socio-racial de la colonia, la República y el racismo moderno. Dicho a breves rasgos, a razón de que la mezcla racial se convierte en un problema insostenible e indescifrable porque impedía identificar la diferencia racial a partir del color de la piel o la textura del cabello, para mediados del siglo XVIII surge la propugna del matrimonio gestionado como política para el control y el orden social a través de la administración del matrimonio que conllevaba la regulación de la natalidad y los cuerpos sexuales, principalmente el de la mujer con sus respectivas categorizaciones para las distinciones de raza y condición social: mientras que las mujeres de élites españolas y criollas se convirtieron en las protagonistas de una contienda por el prestigio y los honores sociales que debían estar siempre tuteados por los varones y sus familias, las mujeres de estratos sociales inferiorizados eran presas de las ventajas sexuales de los hombres. Cuando se definió la categoría social de mestizo, asegura Stolcke (2009), las patentes de las desigualdades socio-políticas y de género adquirieron un estatuto legal (p. 21).

Este tipo de administración estaba asociada con la aplicación del principio de pureza de sangre en América. El principio de limpieza de sangre en la sociedad colonial del Nuevo Mundo "sirvió para distinguir no solamente a aquellos sospechosos de ser judíos o criptojudíos de los cristianos viejos e indios, sino también a los esclavos negros y a sus descendientes." (Stolcke, 2009, p. 17). Además, señala la autora, por un lado, una "lógica genealógica" cumplía un papel fundamental al condicionar el control del matrimonio, del 
sexo y la sexualidad a partir de relaciones de género diferenciadas y específicas con el fin de salvaguardar la jerarquía social, y por otro una forma de gradación de la "civilidad" se medía en términos religiosos a base de preceptos morales cristianos más que en criterios raciales. Stolcke señala que este orden moral y religioso de la conducta de la doctrina de la pureza de sangre se extiende en América española hasta finales del siglo XVII.

La insistencia de prohibir los matrimonios contra la norma, según esta autora, está presente también en la República que solo admitía uniones endogámicas y aboga por ellas. Pero aquí, ya desde el siglo XIX y aun siendo Cuba colonia española, los límites establecidos para las mezclas raciales se sustentan, según Stolcke (2009), en un concepto moderno de raza formulado por el racismo científico de los naturalistas europeos. Dicho con más precisión, esta modificación proviene del racismo moderno formulado en Europa del siglo XVII y se aplica al nuevo mundo desde el siglo XVIII. Para la autora este giro implica un paso de la "ontología teológico-moral" que remitía a un origen común (o a la unidad humana diferenciada por la conducta moral), al énfasis de las diferencias basadas en las distancias culturales y físicas. Es decir, "la ideología de la pureza de sangre pasó de ser un concepto moral-religioso de la identidad y jerarquía social a una moderna noción realista de la desigualdad socio-económica a medida que se desarrollaban nuevos modelos para la interpretación del orden en la sociedad y en el universo durante el siglo XVIII." (Stolcke, 2009, 21).

La limpieza de sangre que velaba por el orden de una jerarquía, al adscribir al racismo moderno, condujo a que en el siglo XIX el control social de la jerarquía ya no se direccione a la vigía moral-religiosa por su perpetuación, sino que pase a enfocarse en su naturalización. Entonces, plantea Stolcke (2011b), la doctrina imperial de limpieza de sangre que no representaba un estricto sistema de clasificación racial, sino más bien una ontología teológica, fue sustituida por la búsqueda de leyes naturales. Clasificar ahora tendrá que ver con la formulación de elementos característicos para nombrar al otro. Estas características en la mirada del racismo científico pasan a construir al otro dentro de concepciones innatas-naturales y hereditarias (de origen racial).

El racismo moderno entonces estaría basado en las tesis del naturalismo europeo que pone el hiato de la diferenciación racial en la dotación biológica indeleble (natural) de cada raza. Citando al antropólogo Descola, Stolcke (2011a) plantea que el naturalismo es una visión dualista del mundo que se obstina en precisar y "clasificar los seres vivos según si están gobernados por las leyes de la materia o por el arbitrio de las convenciones sociales" (p. 6). El naturalismo pone en marcha una mirada binaria (ver cap. 2) del mundo esta vez para oponer naturaleza/sociedad, naturaleza/cultura que según Stolcke (2011a) tiene cabida a través del dualismo cartesiano, y que a través de éste justifica discriminaciones, exclusiones, desigualdades -económicas, sexuales, raciales- atribuyendo su existencia a diferencias biológicas, innatas: naturales/naturalizadas. 
La naturalización es posible en una sociedad que parte de esa visión dual del mundo reduciendo fenómenos socio-culturales y políticos a características naturalizadas y específicas. Entonces, plantea Stolcke, mientras que en las postrimerías de Europa del siglo XVII los naturalistas desplazan su atención de la preocupación por la unidad de la especie al estudio de las diferencias físicas y culturales entre humanos. Tal desplazamiento permite designar el lugar que le corresponde a cada raza en la cadena evolutiva de los seres vivos a partir de la formulación de tipologías sustentadas en la asociación de rasgos fenotípicos y características morales e intelectuales, al terminar el siglo XVIII

este interés por las diferencias 'raciales' en el género humano se plasmó en las primeras formulaciones de lo que se ha dado en llamar el racismo científico, a saber, la demostración científica de que diferencias morales y culturales tendrán su raíz en la dotación biológica. (...) en el siglo XIX, teorizaciones más elaboradas que asociaban desigualdades sociopolíticas con diferencias 'raciales'. Ejemplos de este naturalismo científico son las doctrinas sociales tales como el socialdarwinismo, el socialspencerismo, el lamarckismo y la eugenesia, que se popularizaron en la segunda mitad del siglo XIX y que permitían atribuir las desigualdades sociales a la actuación de las 'leyes de la naturaleza'. (Stolcke, 2000, p. 44 - 45).

Entonces, la cuestión principal de las diferencias naturalizadas es que son dotadas de significado social para legitimar relaciones desiguales de poder. De allí que Stolcke (2000) postule entender al racismo como "un procedimiento ideológico mediante el cual un orden social es presentado como natural” (p. 24), y por tanto, el racismo pasará a ser la creencia en la superioridad inherente de una raza sobre las demás y su derecho a dominarlas.

Marisol de la Cadena (1997) platea que la popularización del naturalismo científico moderno en el siglo XIX creo un nuevo orden mundial. Para la segunda década del siglo $\mathrm{XX}$, las élites latinoamericanas con la finalidad de participar de este nuevo orden del racismo científico produjeron una noción propia de raza, basada sí en la biología, pero atravesada por completo de versiones nacionales de lo que significaba ser blanco. Es así que la decencia en el Perú pasó a ser una categoría de distinción basada en una definición biológico/moral de la raza ${ }^{20}$.

\footnotetext{
${ }^{20}$ Hay un temor a no ser blanco que en el caso del Cuzco, según de la Cadena (1997), condujo a los indigenistas a elaborar taxonomías sociales que aun cuando se mantenían dentro de los márgenes de las definiciones bilógicas de la raza se ignoraba, a propósito, los rasgos fenotípicos para que estos no terminasen ubicándolos en el lugar de aquellos a quienes estos rasgos subordinaban. Es así que el proyecto indigenista de los intelectuales cuzqueños que a primera vista exaltaba la civilización Inca y la defensa del indio, sirvió para elaborar una identidad para sí mismos con alcance nacional. Esta identidad consistía en trenzar discursos sobre la civilización Inca con ideas de decencia y con identidades existentes en el Cuzco. Ello resultó en una taxonomía social que clasificaba a la población en Indios, mestizo y gente decente (blancos). La decencia diferenciaba racialmente evadiendo los fenotipos y ampliaba el concepto de raza haciendo énfasis en las ideas de moral, cultura y educación. Estas eran cualidades que se heredaban de generación en generación, desde la "cuna" (p. 8). La decencia fue una reformulación de los códigos de honor coloniales con ayuda de la noción científica de raza y la ideología liberal. Sirvió
} 
Si desde el siglo XVI América Española usó una tipología racial para clasificar la posición de cada persona en base a la concepción de limpieza de sangre y a la presunta jerarquía entre Blancos, Negros africanos e Indios aborígenes, hacia mediados del siglo XVII, dice Fitzell (1994), la organización social en los Andes no tiene como base exclusiva el discurso de las relaciones de sangre que sobrepasan las diferentes nomenclaturas dentro de la categoría de "castas" incluyendo jerarquías de diversas y complejas características sociales y culturales. En Ecuador, dice Fitzell, "en la práctica” para las diferenciaciones sociales de status racial importaba los usos que se asemejaran a normas europeas como la forma de hablar, la indumentaria, las maneras, riqueza o las labores.

Lo que los viajeros y científicos del siglo XIX hicieron fue retomar el discurso de las relaciones de sangre para referirse a la realidad ecuatoriana. Y lo hicieron a partir de tres focos: la discriminación tripartita (blancos, negros, indios) “(...) basada en la supuesta descendencia de sangre como el único criterio explicativo de las relaciones jerárquicas (...)"; la explicación de la condición de los indígenas de la sierra a partir de del “(...) esquema ideológico con el que estaban familiarizados: el Otro bárbaro definido en oposición a la civilización europea" (Fitzell, 1994, p. 32); la descripción empírica de la vida cotidiana del Ecuador y, a través de ello, el establecimiento de las diferencias, límites y distancias raciales entre el otro y el nosotros dentro de un contexto europeo que se actualizaba por el discurso del progreso, mismo que explicaba las diferencias sociales y culturales ofreciendo una justificación científica del interés en la experiencia de lo exótico.

El racismo científico en Ecuador tiene cabida, en primera instancia, gracias a que viajeros y científicos europeos tenía nexos con los terratenientes de Quito quienes orientados hacia Europa legitimaron a través de estos nexos el trabajo y la posición social de los científicos (y al unísono el de los terratenientes) en el país. En segunda instancia, la modernidad católica de García Moreno, no solo fractura los lazos entre viajeros, científicos y terratenientes, sino que, advierte Fitzell, extiende la visión de la ciencia hacia el proyecto de nación a través del establecimiento de puentes directos de relación entre científicos nacionales y extranjeros. Relación que permitió el desarrollo de las ciencias positivas en el país ya que la ciencia en éste país de los Andes, en gran medida, logró profesionalizarse gracias al aporte de los científicos extranjeros.

Esto quiere decir que la modernidad católica vislumbró un proyecto de nación que conjugaba catolicismo con ciencia positiva. La nación moderna era una nación que

políticamente para afirmar premisas de igualdad y legitimar privilegios sociales que resultaban de algo que se consideraba un mérito personal en sí mismo: adquirir la educación. La educación tiene para la época un componente cuasi-biológico, pues se creía que era transmisora de virtud, acumulada generacionalmente creaba refinamientos que se presentaban como "innatos". Así, a ser biologizada, la educación purificaba la hibridez fenotípica permitiendo una conversión a lo socialmente blanco. Así, la impureza del fenotipo podía ser purificada a través de la pureza moral (p.9). 
encontraba en el catolicismo el elemento aglutinador de su población diversa y dividida, y en la ciencia su elemento de reorganización.

Otro elemento que cabe señalar aquí, y que se desprende de lo dicho, es que la mirada de los científicos y viajeros europeos implica, como se advirtió ya, una imaginación de la nación como objeto imaginado por otros. Y esa imaginación -foránea- interactúa con la imaginación local de la comunidad nacional. Lo que deriva en que ese elemento de reorganización nacional como lo es el positivismo en el proyecto de nación moderna/católica/positiva, pase a ser también un elemento de diferenciación racial.

Desde la incursión de la Misión Geodésica de la Condamine en el siglo XVIII, pasando por la filosofía natural romántica del viajero Alexander von Humboldt que inspiró a Charles Darwin a viajar por los Andes con el fin de desarrollar un conocimiento empírico del mundo a través de las ciencia naturales (Fitzell, 1994, p. 39), y llegando al arribo de científicos traídos de Europa por García Moreno, la modernidad vernácula, implica esa interacción entre la modernidad endógena y exógena (Echeverría, 2011) que en este caso permite la armadura de una mirada racial y racializante sobre la nación ecuatoriana.

A partir de García Moreno se crea el observatorio de Astronomía con Johanes Menten, se abre un espacio para la Geología con Teodoro Wolf, la botánica con Luis Sodiro, la Química con Luis Dressel, la matemática con Joseph Kolberg, etc. Una visita fundamental para la emergencia de la Psiquiatría en el siglo XX acontece en 1873. Los franceses E. Gayraud y D. Domec arriban al país y se quedan en el país como profesores de anatomía y cirugía en la Facultad de Medicina y para dirigir los hospitales de Quito. (Fitzell, 1994, p. 40). Estos dos científicos publican en 1886 un estudio titulado "La capital del Ecuador desde el punto de vista Médico-Quirúrgico". Trabajo que sería antesala de la Psiquiatría quiteña pues, según Osorio (2014) inaugura el punto de vista científico de la medicina. Fue expuesto como un estudio en parte "antropológico" de la cotidianidad y las condiciones en las que viven los quiteños, y en parte resultado de las autopsias a gente fallecida, entre ellos indígenas a quienes se encontró, en dicho estudio, con hábitos defectuosos e intelectualmente inferiores. .

Desde el monstruo en México hasta la imagen del indígena intelectualmente inferior en Ecuador, se puede advertir que la ciencia pasa a constituir una base que permite elaborar un relato sobre la nación moderna desde un "fisura" con formas anteriores de establecimiento de la jerarquía racial, que no implica necesariamente el abandono ni la reactualización de las jerarquías raciales de la colonia, sino más bien una suerte de encuentro como sugiere Chatterjee (2008), una existencia compleja alrededor de la problemática de las diferenciaciones socio-raciales, la nación y la formación del Estado moderno que constituyó un terreno presto para el ingreso de las teorías científicas sobre la raza y la organización de varias formas de racismo que responden a las particularidades de las historias nacionales (Segato, 2007; Radcliffe y Westwood, 1999). 
Respecto del ingreso de la ciencia, al pensar las taxonomías de lo mestizo en América Latina, Marisol de la Cadena (2006) considera que la entrada de la ciencia de la raza europea no produjo un distanciamiento entre fe y razón en este continente, sino más bien su combinación como un orden clasificatorio que se expresa en conceptos como civilización y progreso, y se articulan en nociones como raza, clase, cultura, sexualidad, etnicidad, geografía, educación, etc. El mestizaje para esta autora es un orden conceptual clasificatorio hibrido que sobrepasa la observación científica de la mezcla en los cuerpos, la cultura o la raza y por el contrario responde a "políticas conceptuales", a formaciones discursivas genealógicas que se rehacen en los distintos regímenes de conocimiento.

Hago extensiva esta última postura a todo proceso de otrificación nacional para plantear que el "efecto desdoblador" de la identidad en la "modernidad exógena", y el grado de imposición de la "modernidad endógena" sobre la "exógena" que advierte Echeverría (2011), produce esta suerte de encuentro en el que la identidad se construye mediante la conexión de formas supuestamente opuestas, se construye desdoblada, duplicada. Y por otra parte permite y afirma ciertas imposiciones de la identidad cultural de la modernidad endógena (en la medida en que la ciencia europea actúa como un régimen colonial de conocimiento que permite imponer una imagen naturalizada sobre 'otro' inferiorizado, reafirma la colonialidad de la ciencia europea y a su vez genera marcos de resistencia a esa colonialidad).

Encuentro expresado este efecto desdoblador en la hibridez de las identidades, entendida esta no como mezcla racial, sino como "campo de visibilidad" (Polo, 2011) en la medida que es producción conceptual dentro de un régimen de visibilidad; ya que el efecto desdoblador, a la vez que genera identidades étnicas y sociales, actúa como un campo de visibilidad de objetos de saber. La identidad en la modernidad exógena es un "hibrido conceptual", un "híbrido epistemológico" que responde a "políticas conceptuales" que son relaciones sociales que establecen la definición de etiquetas raciales y étnicas que forman parte de un grupo mayor de herramientas utilizadas para clasificar y separar (Marisol de la Cadena, 2006). Y estas políticas conceptuales a la vez implican campos de visibilidad en los que se disputa y define la inteligibilidad de los objetos de saber.

Veamos ahora qué formaciones discursivas propuso la eugenesia en distintos contextos nacionales.

\subsection{La eugenesia positiva y negativa: una discusión del siglo XX sobre "ambiente" y} "biología"

Por un lado, se ha señalado que el desplazamiento de los discursos psiquiátricos de la nosología a la etiología permitió una extensión de los alcances de la psiquiatría que rebasa los límites de la rehabilitación individual dentro de los muros del manicomio para ubicar la práctica en la prevención de la patología y la supervisión del estado mental de las 
poblaciones. Por otro lado, que desde los años veinte y treinta la eugenesia ocupa de manera creciente un lugar privilegiado en los regímenes políticos de occidente en la medida que no solo es una teoría sobre degeneración-herencia y patología, sino una teoría para la interpretación y reconstrucción de los orígenes de las naciones. A ello se suma que efecto desdoblador, políticas conceptuales y horizontes de visibilidad se implican.

Como parte de unos regímenes políticos y conceptuales, las categorías eugénicas sustentan la reescritura de la historia de sus naciones. De allí que el sentido de la eugenesia sea redefinido en cada nación en cuanto a la utilidad de los trazos temporales que permite realizar en torno a los nexos entre raza, saber, historia y nación. Esta redefinición suscita un debate sobre el énfasis en el genotipo o el fenotipo, ambiente y biología para la imaginación histórico-eugenésica de las naciones. Dicho debate deviene en la introducción de la categoría eugenesia positiva frete a la eugenesia negativa defendida por los nazis y para diferenciarse de ella.

Además, con Stolke, Radcliffe y Westwood, Segato y de la Cadena, planteé que la división moderna naturaleza-cultura sobre la que se organiza el sustento del racismo científico, del que proviene el concepto moderno de raza, estuvo asociada a una genealogía sobre las diferenciaciones socio-raciales en América Latina y han constituido una base para las formaciones discursivas hibridas de las identidades (mismidades) que responden a procesos nacionales otrificadores (identificatorios e identitarios). Tenemos entonces aquí un modo de hacer ciencia, en el que ésta es tomada como elemento de elaboración del relato nacional en el siglo XX, que en el caso de la eugenesia comprende una discusión de la historia, el Estado, la nación y la raza en base al binomio degeneración-herencia y a su vez ambiente o biología. Los racismos de cada nación intentaron resolver las disyuntivas que acarrea el binomio herencia-degeneración y la tensión entre eugenesia positiva y negativa conforme a sus intereses.

En la segunda década del siglo XX, en México, la eugenesia habría cumplido un objetivo bastante puntual. Según Laura Suárez y López Guazo (2016), la concepción de selección matrimonial, y posteriormente los consultorios de salud hereditaria, buscaban tutelar el matrimonio con el fin de mejorar la raza en base a principios científicos. En pos del bienestar de la nación, los eugenistas velaban porque el Estado apueste por un "blanqueamiento" de la población que consistía en promover la cruza de razas de jerarquía inferior con miembros de la raza blanca. Ello con el fin de mejorar la raza física e intelectualmente mediante un tutelaje bien dirigido de la reproducción y del proceso de selección.

Aunque encontramos una diferenciación naturalizada de la jerarquía entre razas a partir de definiciones biológicas, como plantea Stolke, estamos aquí ya no del todo frente al matrimonio endogámico, sino más bien frente a la selección matrimonial, lo que es un matrimonio tutelado que no evita la mezcla racial sino que la alienta, pero bajo el control 
del Estado y bajo observación experta-disciplinar-médica, conducidas por un concepto de salud que comprende el mejoramiento racial en términos de mejoramiento de la calidad física, intelectual y psicológica de la raza. No obstante, advierten Suárez y López Guazo (2016), a pesar de promover una mezcla tutelada consideraban pertinente fomentar la cruza entre razas afines y limitar la mezcla para incidir en el mejoramiento racial previniendo la proliferación de los mestizos como productos raciales inferiores.

La mezcla racial propone otro concepto: mezcla tutelada equivale a salud de la raza y la nación, equivale a un mestizaje adecuado; la mezcla sin control equivale a degeneración de la raza y aumento de la criminalidad. Por ello, Suárez y López Guazo consideran que los eugenistas mexicanos coinciden con la postura europea que postula a la higiene racial como preocupación mayor de las naciones. En este país, la constitución etnológica de los pueblos se consideraba importante porque de ella dependía su progreso. Las cuestiones geográficoambientales y educativas ocupaban, como lo postula la teoría de Galton, un lugar secundario. De allí que la salud hereditaria dependiera de un conocimiento etnográfico de la población que actuaría como herramienta eugenésica contra la constitución hereditaria deficiente a la que, por lo general, los eugenesistas atribuían como causa de crimen y procreación de razas inferiores nocivas para el progreso de la nación.

Para los eugenistas mexicanos el crimen tiene un componente racial. La causa principal de la degeneración, el crimen y el estancamiento hacia el progreso era la mezcla de razas deficientes. Sobre ello debía actuar el Estado. Los eugenistas ven al Estado como garante y protector de la selección natural biológica. El Doctor Antonio F. Alonso, un destacado eugenista, encontró en Weismann el sustento teórico respecto de la importancia que tiene para la especie seleccionar los mejores ejemplares y así sostener la continuidad del plasma germinativo entre generaciones. En Lamarck halla la base evolutiva centrada en las modificaciones de los seres por su adaptación al medio. De Darwin extrae la selección natural y la supervivencia de los más aptos.

Suárez y López Guazo escriben que la concepción sobre herencia de los eugenistas mexicanos se inclinó hasta 1950 por una postura lamarckiana que fija su atención en la heredabilidad de los caracteres adquiridos. Desde Lamarck postularon que los individuos eran variables en sus cualidades, pero podían ser dotados adecuadamente en lo moral y físico. Los grupos, entonces eran susceptibles de mejoramiento y adaptación. Eso no impidió que consideren la esterilización de la raza indígena. Una práctica ligada a la eugenesia negativa (anti-descendencia, darwiniano-weismaniana), sostenida por el nacismo e iniciada en EEUU, pasó a ser la opción para solucionar el conflicto que suscitaba la raza indígena en México. Se debía evitar su reproducción. Esto sucede tras la Revolución mexicana. Sin embargo, la opción por la eugenesia positiva antes de la Revolución, de todos modos, consideraba que tarde o temprano la raza indígena sucumbiría en la lucha por 
la vida, y el progreso de México se centraba por ello en la cruza con colonos europeos (Robles y Caballero, 2016, p. 56-57-58).

En México encontramos elementos de ambas eugenesias. Suárez y López Guazo consideran que para 1940 se abogó por una adecuada selección reproductiva a través de una herencia seleccionadora como un cultivo etnológico, que consistía en la selección y adecuado mestizaje para que surja el normal y el apto, que es a su vez producto de la técnica biológica y está regido por la eugenesia. Esta postura condujo a encontrar en el indígena cualidades indeseables (patologías psíquicas y orgánicas) para el progreso de la nación. Los indígenas, en la formación discursiva de la raza de los eugenistas mexicanos, pese a su revaloración por el nacionalismo y los programas indigenistas promovidos por Lázaro Cárdenas, aparecían como disgenésicos o débiles mentales, pero susceptibes de mejora a través de la instrucción higiénica eugenésica. Por ello, era necesario el consejo genético y el certificado prenupcial otorgado por los consultorios de salud reproductiva y clínicas hereditarias que determinaban la pertinencia de la reproducción de parejas que allí debían consultarse. (p. 205)

"Los nuevos conocimientos de la genética relacionados con nuevas enfermedades, revelaban la promesa de limitar las patologías, con una profilaxis adecuada de los futuros progenitores. La medicina moderna mexicana asumió la tradición sajona de la prevención, así como el ambientalismo francés, para orientar la función social de los eugenistas en favor del mejoramiento de la población y consecuentemente de la economía del país." (Suárez y López Guazo, 2016, p.207). Para los eugenistas mexicanos de 1920 el debate sobre ambiente y organismo se manifiesta con una particularidad distinta a la descrita para finales del XIX por Gorbach (2008). Pese a que coinciden con los positivistas del porfiriato de inicios del siglo XX al considerar que las deficiencias degenerativas del indígena podrían ser solucionadas por su cruza con blanco-europeos, la discusión en el contexto del cardenismo ya no tiene que ver con develar el origen de la raza mexicana, sino de velar por la dirección del futuro de la especie, de la raza, de la nación. Persiste en la discusión sobre raza y nación. Ya no para resolver el presente desde la comprensión del pasado, sino desde un futuro ideal que se quiere habitar como nación.

De allí que persista la idea de finales del siglo XIX de un mestizaje como posibilidad de homogenización nacional (Argueta y Ruiz, 2002). Esta vez bajo el tutelaje estatal que controle el mestizaje, proteja y dirija la selección natural biológica, asuma la educación (sexual como Salud Hereditaria y física), condene la prostitución, facilite un control eugénico de la política migratoria, reduzca la proporción de débiles mentales, fomente la regeneración biológica, de cabida a leyes de esterilización de razas débiles, garantice la reproducción del más fuerte y se encargue de civilizar al indígena.

Convertido el progreso en un problema biológico, el Estado estaba en la capacidad de evitar la selección natural biológica, la controla, la administra. Frente a la selección natural asume 
que la sociedad debe defenderse de ella detectando a las poblaciones portadoras de caracteres deficientes. $\mathrm{Y}$ en el caso de los indígenas, el Estado debe encargarse del mejoramiento de la raza en pos del porvenir de la nación. La eugenesia naturaliza las diferencias raciales, pero frente a la naturaleza de la selección biológica considera que el Estado debe defender a la sociedad de la posibilidad de la degeneración biológica y garantizar una adecuada/tutelada selección natural biológica.

Un caso contrario lo encontramos en Argentina, donde el Estado debía ocuparse del azar de la selección natural, del que Darwin había advertido, para ubicar a cada individuo en el lugar que le corresponde. Para los eugenistas argentinos el Estado debía defender el orden social del azar que permitía un posible ascenso de los "otros" de la nación, mientras que el Estado mexicano se debía preocupar por proteger a la especie y la perpetuidad de los más aptos, el Estado argentino se debía encargar del posible ascenso de los no tan aptos. Así, según Gustavo Vallejo (2016), la eugenesia en este país coincidió con la utopía liberal europea de una sociedad sin conflictos, donde cada individuo acepta su lugar en la sociedad, e incluso, protege una jerarquía social de la movilidad: procura que el cambio natural de la sociedad no proceda por saltos azarosos. La burguesía que llegó a ocupar el lugar social en el que se encontraba, desde esta perspectiva, no sería desplazada por esa misma movilidad que la situó allí.

"La ciencia de Galton venía a reforzar las estrategias de control social que el liberalismo buscó a través de reapropiaciones del darwinismo, como la que llevó cabo Herbert Spencer para plantear una gran metáfora social, donde Naturaleza y Mercado quedaban equiparados a fin de establecer una directa correlación entre la lucha que debían sostener aquellas especies que pugnaban por sobrevivir con los individuos y grupos sociales que trataban de insertarse en la economía de la revolución industrial" (Vallejo, 2016, p. 171). Por ello, para este autor, la utopía liberal de la sociedad sin conflictos, instrumentalizaba a la eugenesia para que esta defina qué vida debía ser vivida en un mundo "superabundado y carente de alimentos", reforzando así el lugar social que cada una de esas vidas debía ocupar. Se trataba de una comprensión biológica en la que la realidad social aparece como un designio inmodificable: natural, pero sostenido desde el Estado. Así, solo quedaba ocuparse de los resquicios del ambiente. De allí la acogida del ambientalismo de Galton en Argentina como una vía científica para la moralización del orden social naturalizado.

En Argentina, dice Vallejo (2016, 2005), fue la difusión del Darwinismo social, a cargo de intelectuales de tanta importancia para la cultura científica de la nación, como José Ingenieros, la que preparó el camino para la eugenesia. Desde 1920, la Liga de Profilaxis Social, creada con el propósito de combatir los venenos sociales (alcoholismo, enfermedades venéreas, crimen), propuso medidas para mantener el orden social naturalizado. Cimentaron un sistema de certificación de la aptitud eugénica para parejas con planes de casarse, se establecieron un orden legal para introducir los contenidos 
eugénicos en la educación, motivaron una lucha por la defensa de la raza y postularon el impedimento matrimonial a enfermos de lepra.

Estas medidas tuvieron un alcance mayor tras el crac de 1929 y el primer golpe de estado en este país, contexto en el que el liberalismo conservador encuentra una oportunidad para recobrar control político. Aquí, la eugenesia reconfigura su campo estableciendo el estereotipo nacional deseado a través del control migratorio. El golpe de estado construyó nexos entre un sector de la cultura científica y política y, la utopía de la sociedad sin saltos azarosos afianzaba los lazos entre Iglesia Católica y liberalismo.

En Argentina, asegura Vallejo (2016), se trata de una variante de la ciencia de Galton que se basa en la biotipología del italiano Nicola Pende. Esta es una eugenesia que logra que la tecnocracia no repela los preceptos del Vaticano, sosteniendo y fusionando los valores burgueses (como la defensa de derechos civiles) con la legitimación biológica del totalitarismo político. Por otra parte, este país "también tuvo una notable influencia de Vallejo-Nágera. [Así] se propagó una eugenesia ambiental que invadió 'el plexo normativo civil', permitiendo 'ser menos estridentes en su aplicación' pero más efectivas y 'capaces de perdurar en el tiempo'.” (Campos, 2016, p. 145). Dicha eficacia, asegura Vallejo (2016), se refleja en que el ambientalismo en este país, no solo compaginó con el liberalismo conservador de inicios del siglo XX, se extendió hasta la última dictadura en la que se desplegó un plan para separar a hijos de sus padres subversivos y colocarlos en otro ambiente que les asegurase una mejor formación y porvenir. Plan similar al supervisado por Nágera en el franquismo, en el que se sustraía a hijos de republicanos para su entrega a familias correctamente constituidas.

En cuanto al ejercicio sobre el control de la población, Argentina no se inclinó del todo por la práctica de esterilización masiva que caracterizaba a la eugenesia negativa promulgada por el régimen nazi y el norteamericano. Su énfasis en la eugenesia positiva los inclinó por el control del matrimonio. En 1937 lograron que el Estado instituyera el certificado médico prenupcial encargado de evaluar la disposición de engendrar descendencia sana. Desplazar el eje de la esterilización permitió un mayor alcance sobre el control de la población. Se impuso con ello la alternativa ambientalista sobre la genética. Se trataba de la corrección moral de los desvíos. Ello disminuía sus imitaciones, permitiendo desplegar su ejercicio desde la medicina individual hasta la medicina social y del trabajo, así como al derecho, la tutela de menores y una presencia extensa en la criminología. La corrección moral permitió mayores diálogos con el poder y la interpelación a los ideales de igualdad de la democracia a la que oponían una sociedad fundada en razas inferiores y superiores con su reflejo en clases dirigentes y dirigidas (Vallejo, 2016, p. 176).

En esta concepción del mundo social, Estado y biología se correspondían en la utopía de un orden futuro en la eugenesia para dejar sin lugar a los cambios azarosos, la imprevisibilidad de la lucha darwiniana que incomodaba a las élites. 
En efecto, la biotipología era 'política sobre bases biológicas' o también 'biología política'. Se valía de la biología moderna y el desarrollo reciente de la endocrinología para articularlos con preceptos religiosos. Era una utopía tecnocrática que concebía el poder desde la integración de ciencia, política y religión. Dentro del organismo social, el rol de la eugenesia era detectar el 'justo lugar' que cada uno debía ocupar en la sociedad. Para eso la biotipología estudiaba individualizada y totalizantemente las poblaciones, a fin de detectar predisposiciones morbosas, candidatos al delito o a la enfermedad, detectándolos a tiempo, antes que su mal afectara al cuerpo social. Se introducía en lo profundo del ser a través de un deslazamiento de la antropología criminal a la antropología endócrina. De los rasgos fenotípicos al funcionamiento hormonal y del cuerpo al alma, para hallar alteraciones fisiológicas y/o morales (Vallejo, 2016, p. 177).

$\mathrm{Al}$ recomponer el fundamento darwiniano de la eugenesia, la biotipología pendeana tuvo cabida en el ultranacionalismo argentino, que a diferencia de México no promueve un mestizaje controlado que mejore la raza, sino que lo evita porque en éste advierte la degeneración por la acumulación de taras hereditarias. De allí, piensa Vallejo (2005) la apuesta por una migración europea-deseable hermética a los judíos, negros, mulatos, mestizos y criollos. La raza es un argumento biológico-político (biotipológico) de orientación médico filosófica en aras del desciframiento y control de la naturaleza que compone cuerpo y alma y con ello detecta, clasifica y previene el SER de la otredad y sus "diversas formas" de presencia peligrosa para la nación (Vallejo, 2005, p. 161). Porque a diferencia de otras épocas, como dice Gorbach (2008) refiriéndose a los monstruos y anomalías de México decimonónico, en la modernización de la mirada médica, de la otredad ya no preocupa su animalidad-inhumanidad, sino su SER.

En una línea parecida a Argentina, el ambientalismo contó con gran aceptación y tuvo un gran desarrollo en España durante el franquismo. La inclinación por el ambiente fue, según Ricardo Campos (2016), una decisión política que permitió hallar en los marxistas al agente patógeno de la nación, y ver en la Republica y la Democracia los causales ambientales de un orden perdido y de la degeneración de la raza española. Ello originó una interpretación socio-patológica de la historia española que impugnó la modernidad para apostar por la reincorporación de un pensamiento, de unos hábitos y unas conductas del pueblo español del siglo XV y XVI para lograr así el saneamiento moral del medio ambiente. Este saneamiento, para psiquiatras eugenistas españoles como Vallejo-Nágera, permitiría reforzar psicológicamente el fenotipo ideal de la nación, previniendo que éste no degenere en genotipo.

En la obra del Psiquiatra Juan Antonio Vallejo-Nágera, según Campos y Novella (2016) y Robles y Caballero (2016), se condensan los principios políticos de la eugenesia española. En su obra aparecen conexas la eugenesia y la idea de Hispanidad de Maeztu, compuesta, dice Robles y Caballero (2016), por una estructura dual que conjuga Raza y Patria y que embonan en el tradicionalismo católico. Se distancia de la eugenesia que denomina como negativa y 'geneticista' que se centra en la genética y en la selección de los tipos mejor 
dotados biológicamente. Apuesta por una eugenesia conductista de contenido medioambiental que considera que la influencia del medio ambiente sobre el individuo es mayor a la herencia biológica. La herencia biológica no es determinante en esta postura ni ve infalibles las leyes de la herencia. Desde aquí explica la degeneración de la raza española, no desde la biología, sino desde un medioambiente compuesto por la democracia y la industrialización moderna.

Dado que la democracia era el enemigo de la patria, proponía desterrarla e implantar una sociedad gobernada por una élite aristocrática conformada por selectos. De allí que su higiene racial no remitía a la biología, sino a lo moral y espiritual, ampliando así el concepto de raza al punto que encontraba unidad racial entre España y América a través de un carácter espiritual conformado por lengua, catolicismo, hábitos y cultura. Su línea espiritualista ató vínculos entre raza y patria. El uno no existía sin el otro, y la coherencia de ambas respondía a su procedencia de un pasado glorioso español en el que se habría generado una cultura católica a la que se debía retornar para emprender la regeneración de la raza. Raza no alude a lo puro, no es genotipo. Raza es una amalgama de alma con patriotismo que constituían la hispanidad, y a su vez constituía al español como tal.

Para revertir la nivelación de las clases sociales generada por una democracia que favorecía a las clases inferiores en lugar de a las jerarquías selectas como quería Nágera, propuso un programa de regeneración que según Campos (2016) consistió en: a) auto-mejoramiento de los selectos en potencia, a través de una modificación individual del modo de existencia imponiéndose una disciplina mental, austeridad, moral, altruismo; b) efecto de ello sería la creación de grupos sociales por afinidades, en los que se fomentaría los deseos de automejoramiento que tendrían como referente ideológico la hispanidad representada por los "superselectos de la raza" (personajes de ciencia, armas, letras) y rechazando a los modelos creados por la sociedad de masas (boxeadores, toreros, etc.); c) divulgación de las vidas heroicas como modelos del yo ideal; d) imitación de selectos y superdotados para dotar a la raza de una aristocracia espiritual que potencie las características raciales de la categoría superior; e) educación higiénica del individuo marcada por la disciplina moral para hermetizarse de un medioambiente degenerador (p. 138).

Se trataba de un proyecto en el que importaba alcanzar un deber ser, un yo ideal para que la cultura (entendida como intelecto científico, militar, artístico) influya sobre el genotipo, para que una política racial y una higiene racial mejoren el ambiente.

En la institución llamada “Gabinete de Investigaciones Psicológicas” pasó de las propuestas teóricas a las acciones concretas. Allí se hizo de marxistas, republicanos, demócratas y ateos unos objetos de estudio en base a la dicotomía salud/enfermedad. Sus investigaciones, dice Robles y Caballero (2016) partían de tres premisas: "el establecimiento de las relaciones entre la personalidad biopsíquica y predisposición constitucional al marxismo", segundo "determinar la proporción del fanatismo marxista entre los inferiores mentales", 
tercero "determinar igualmente la proporción de psicópatas antisociales entre las masas marxistas" (p. 44- 45). "El interés en relación a la eugenesia en estos trabajos radica en que pretendían demostrar, a partir de una muy singular interpretación de la biotipología de Krestschmer, que el marxismo era una patología mental y los militantes de dicha ideología eran seres anormales que podían ser combatidos por medio de una severa política punitiva moral, de carácter ambientalista." (Campos, 2016, p. 139).

La patologización de la disidencia política y su neutralización, dice Campos y Novella (2016), siguió unos pasos que consistieron en la identificación de la higiene mental con el catolicismo y la moral como garantes de la estabilidad y el orden. Por otra parte la redefinición de la frontera patología/normalidad para legitimar un orden, y finalmente, definir al enemigo de la patria como sujeto patológico/criminal/inferior/antiespañol para posteriormente segregarlo.

La higiene mental entonces se encargaba de persuadir a los españoles a aceptar su destino, misión en la historia y su lugar en la sociedad "por medio de la ascesis y la disciplina en torno a un jefe" (p. 76). La interpretación socio-patológica de la historia conllevó un plan de regeneración que consistía en recuperar valores católicos del siglo XVI y sanear moralmente el ambiente para reforzar “(...) 'psicológicamente el fenotipo para que este no degenere en genotipo'.” (p. 77). Ello implicaba un mejoramiento no de las cualidades biológicas como en el nacismo, sino una acción constante sobre el medio ambiente y favoreciendo la dura disciplina de la higiene de la raza y la reconstrucción del individuo ( $\mathrm{p}$. 78).

El consejo prematrimonial y el certificado prematrimonial, dice Campos (2016), solucionarían el dilema sobre si favorecer la calidad de la raza frente a la cantidad. La favorecida sería la calidad. Para ello, Vallejo-Nágera, une una vez más ciencia y religión con fines morales para elaborar una distinción entre Eugenesia y Eugamia. Consideró que "la eugamia era la rama de la eugenesia que se ocupaba de la 'selección de los conyugues desde el punto de vista caracteriológico, no somático como la eugenesia'. La diferencia estribaba en que la eugenesia se interesaba por 'la unión de los genotipos sanos' mientras que la eugamia lo hacía por 'la fusión de los tipos biopsíquicos que se complementan con arreglos a leyes genéticas y psicológicas para que la personalidad de la prole sea lo más equilibrada posible'.” (p. 144). Aquí vemos cerrado el complejo, y a ratos contradictorio, círculo de la eugenesia ambientalista que conjuga raza, ciencia, historia, patria/nación, moral católica con el ejercicio punitivo en pos de unos ideales nacionales políticos específicos.

La razón por la que Vallejo-Nágera tiene una amplia recepción en Argentina se debe al lugar que ocupa la Iglesia Católica en el país a inicios del siglo XX. "Dada la imbricación entre la cuestión racial y nacional, el enfoque nacional-católico de Vallejo tendrá cabida allí donde la institución romana mantiene influencia política efectiva y/o está en conflicto 
activo con las fuerzas gubernamentales.” (Robles y Caballero, 2016, p. 58). Ello, según los autores, no sucedió en Uruguay donde el laicismo prosperó desembocando en el batllismo, donde el eugenismo alcanza su mayor auge. Por ello, en Uruguay la esterilización fue largamente discutida hasta los 40 estando cerca de ser elevada a Ley, pero finalmente se impuso la práctica de la certificación prematrimonial (p. 59).

Otro caso de ambientalismo y neo-lamarkismo se encuentra en Colombia. Esta vez la eugenesia no concatena Raza/Patria/Moral-Católica como en el caso de España y Argentina. En la costa Caribe colombiana, durante los primeros treinta años del siglo XX, Jason McGraw (2007) cuenta que las ideas eugenésicas, sobre lo que se comprendió como un proceso de decaimiento racial, fueron la fuente de inspiración de proyectos que buscaron promover la salud y la limpieza de las poblaciones negras de la costa, para eliminar, lo que se entendía como su contaminación biológica y cultural. Según este autor, la voluntad por mejorar racialmente al Caribe emanaba, en parte, por la posición geográfica de la región como salida al mundo. McGraw considera que la renovación racial contenía una naturaleza moral y que el higienismo se enfocó en mejorar las condiciones de vida y la productividad de la población trabajadora.

Según McGraw, los programas de higiene del siglo XX en el Caribe colombiano distan de los anteriores en este país, porque los esfuerzos por eugenizar la raza provienen directamente de intelectuales que emprenden una campaña contra el alcohol, ello a pesar de las resistencias que generaba su monopolio por la gran cantidad de impuestos que generaba. La campaña pudo extenderse finalmente como un esfuerzo por mejorar la raza y tuvo a la clase trabajadora como objetivo principal (p.68). No obstante, cuenta el autor, pese a que los programas de salud y de higiene pareciera fueron diseñados para restituir la unidad de Colombia tras el desorden desatado por la guerra de los Mil Días y de la separación de Panamá, las motivaciones morales y raciales de dichos programas de salud e higiene terminaron acentuando la divisiones culturales que existían en el país.

McGraw anota sobre este punto que la visión neo-lamarckiana al considerar que los rasgos adquiridos son heredables, conduce a percibir en las causas externas posibles causas de degeneración. Por ello plantearon la moralización del ambiente como solución social para la renovación biológica. La eugenesia estableció un nexo entre el indio y el negro para sustentar la condición de ambos grupos como salvajes incivilizados. Representaron al negro costeño como inmoral, atrasado y salvaje nómade del Amazonas. La eugenesia expuso los problemas de la falta de orden, y a la vez, propuso la solución: la higiene como lucha contra la degeneración racial y como deber patriótico. Sin embargo, los programas neolamarckianos de salud que promovía la moralización y civilización de masas analfabetas y pobres para su asimilación social a la nación, comúnmente reforzaban las diferencias culturales que impedían la unidad de Colombia. Catalogar la incivilización justificó la tutela del Estado sobre estos grupos y llevaba así a los costeños al centro de una nación homogénea reproduciendo las distinciones que se deseaba superar. 
La eugenesia ambientalista, al detectar los problemas y postular sus soluciones, creaba marcas raciales y daban soluciones eugenésicas y paternalistas. Es decir, según McGraw, creaba "taxonomías académicas" que reafirmaban la autoridad intelectual de blancos sobre masas mestizas e indígenas al denominarlas incultas e inferiores, y dieron paso a una resistencia frente a la emergencia de lo negro como ideal eugenésico nacional. La mezcla aquí, más que un paso tutelado hacia la homogeneidad nacional como en México, constituye una forma de creación de diferencias negativas dentro de la nación sobre todo si implicaba a la población negra. Las diferencias negativas hacían referencia a que el mestizo sí se dejaba influenciar por lo extranjero. Los negros no. Por el contrario se resistían a la influencia de lo blanco y a su mezcla racial. Ello era considerado un grave problema para los propósitos eugenésicos de mejora racial y progreso nacional (p. 66).

Otro país en el que la eugenesia se concebía así misma como el camino a la civilización, crecimiento económico y estabilidad política y social, es Perú. En este país, puesto que la raza actuó como categoría política que anuda discurso económico con medicina, raza y economía pasan a ser una forma de narrativa sobre la nación. La mezcla racial con el europeo, dice Yzú Rossini (2016), es promovida como una vía a la civilización. Se considera que de la mejora de la raza depende el acceso a la civilización. Hay que mejorar la raza para ser civilizados que equivale a decir 'ser modernos' (productivos, científicos, bien portados, cultos, morales, católicos, profilácticos, sin vicios). A pesar de que este discurso condujo a personalidades como Sáenz a ver en el indígena un ser inferior psíquica y somáticamente, otros científicos como Carlos E. Paz Soldán construyeron un concepto de raza más general no direccionado a una sola población.

Paz Soldán, en su concepción de raza, hace un llamado al americanismo intelectual, que consistía en el acercamiento "científico y sentimental" de distintas autoridades sanitarias de Latinoamérica (augenistas, higienistas, médicos sociales) para salvar a las naciones (Yzú Rossini, 2016, p. 53-88). Y a través del concepto de "soma ancestral" que promulga que cada raza en el mundo tiene una carga ancestral que permite comprender su devenir en sociedad y explicar el crecimiento o estancamiento de su población, comprendió la eugenesia en la línea que relacionaba la raza y ambiente como determinantes para el bienestar genético y somático de los individuos. Vio en la eugenesia una apuesta a largo plazo para la mejora de la raza y la superación de las condiciones sanitarias existentes para que esta mejora acontezca. De allí su preocupación médica, eugénica e higiénica contra el alcoholismo y la coca. $^{21}$

\footnotetext{
${ }^{21}$ Recuérdese en este punto el programa social y científico que trazan las medidas preventivas de Higiene Mental de la Asociación Latinoamericana Pro-Salud Mental citado en el capítulo primero. Por razones que distan en su fundamento pero no del todo en su objetivo, eugenesia e higiene, en la resolución del "Tercer Congreso Latino-Americano de Salud Mental", se configuran como un proyecto anti toxicomanía en procura del bienestar y conducción científica de la nación. Allí hay un consenso médico político del que Ecuador forma parte.
} 
En Perú, según lo desarrollado por Brunella Yzú Rossini, Carlos Paz E. Soldán, apostó por la eugenesia como componente elemental que permitiría que la educación de las masas actúe como un medio para la civilización de los individuos y la mejora de la descendencia a la que se denominó como "progreso genético". Para ello, propuso un mayor control sobre el cuerpo y la reproducción. Soldán, habría optado por la medicina social y el higienismo para justificar y legitimar la inmersión de las autoridades en la vida privada de la población. Es así que higienismo y eugenesia fueron ejes fundamentales para la modernización del Estado peruano y del esfuerzo por lograr una mejora y un progreso racial a través de políticas e instituciones estatales vinculadas a la asistencia y prevención. La autora destaca que para cumplir con tal objetivo, la asistencia y la prevención, se concentraron en mayor medida en los niños y las mujeres.

Con un énfasis en lo biológico o en el ambiente, la raza ocupa el centro y los bordes de las preocupaciones que le dan cabida a la eugenesia en América Latina. No solo porque obtiene de esta ciencia sustento teórico para detectar problemas en torno a lo racial y ofrecer soluciones concretas como la esterilización a indígenas, o la tutela científica y estatal sobre la reproducción de la población en general y de grupos cuya inferioridad fue naturalizada. La eugenesia es asumida como una base científica para releer la historia, no revisarla, sino rehacerla, recuperarla, recomponerla. Para la eugenesia no estaba en cuestión la verdad sobre lo dicho, sino el sentido y la verdad sobre lo que se dice y lo que está por decirse, lo que se recuerda y recordará de la nación.

La eugenesia permite re-escribir la historia, producirla (Rufer, 2010b), elaborar un relato disciplinar propio (De Certeau, 1993) no especializado (Visacovsky, 2005, 2007) con capacidad de convocatorio y aglutinamiento de la comunidad imaginada (Anderson, 2007) y con poder de instituir la autoridad (Bourdieu, 2001) de su relato. La eugenesia toma la raza y crea trazos políticos de tiempo (Rufer, 2010a, 2010b) que se conectan con la imaginación de la nación. En esos trazos ayuda a perfilar identidades ideales, mismidades y otrificaciones (Segato, 2007) que constituyen a los objetos de saber de su relato y delimitan distancias con los sujetos del saber (Foucault, 2010a, 2010b; De Certeau, 1993).

Al unir raza, historia, biología y nación articulan una forma de definir distancias temporales que oscila entre presente(s), pasado(s) y futuro(s). Si hay algo general que se podría destacar de la eugenesia, no es precisamente esa inclinación tan notoria sobre el control del cuerpo para el control de la reproducción sexual, sino más bien que ese control del cuerpo y la reproducción sexual se concatenan con un carácter utópico de la historia nacional. La eugenesia aparece no solo como una nueva forma de imaginación de la nación, sino como una forma utópica de control biológico en la imaginación de la nación, una forma de organizar la heterotopia nacional (Chatterjee, 2008), ya sea mediante la homologación de la heterotopía, ya sea por la tutela de su reproducción o la moralización del ambiente en el que 
adquirían los caracteres que heredarían a sus sucesores raciales. Y esta imaginación de la nación involucra nociones políticas de tiempo.

Patología, normalidad, raza, ambiente, biología, nosotros, otros: se encuentra en estas categorías elementos de diagnóstico del presente. Ya sea que se acuda al pasado para restituirlo en el presente, ya sea que se trate de evitar la continuidad de un pasado, hay un hiato en el futuro biológico de la nación. De ello depende su progreso, su civilización/modernización o su diferenciación con lo moderno como en el caso de España. Imaginar el presente de la nación en tiempo futuro-pasado conduce a los eugenistas a entender y promover el progreso de la nación como un problema biológico de mediano o largo plazo. La "temporalidad compleja" (Jelin, 2012) se expresa en el carácter utópico de los ideales raciales-nacionales de la eugenesia.

\subsection{Publicaciones extranjeras sobre eugenesia y psiquiatría en los Archivos de Criminología}

Para los psiquiatras en Ecuador de mediados del siglo XX, la búsqueda de referentes extranjeros y categorías que actúen como marcos interpretativos de los objetos que van construyendo es una tarea que los mantiene atentos. Parte de esa búsqueda se relaciona con la problemática de la raza y se suscita en otro contexto: Ecuador inicia el siglo XX con un proceso de separación entre Estado e Iglesia que implica un quiebre entre la imaginería religiosa-católica de la nación desplazándola hacia una imaginería laica. Ahora la ciencia no solo forma parte de la modernización del país como sucedía en el Concordato, a partir de la Revolución Liberal la ciencia es un elemento clave en el proceso de laicización del Estado y por ende de combate al dominio eclesiástico proveniente del Concordato.

La psiquiatría en tal contexto toma otras características (Ver cap. 1). La búsqueda de la causa de la patología ya no se enfoca solamente en el estudio de los cuerpos individuales, ahora abre su mirada a lo social. Hay un esfuerzo en Europa por determinar la etiología, ello que puede ser rastreado en Ecuador en las nuevas formas de comprensión de la patología. Por ejemplo: el marxismo, señala Rodas (2011), tiene cabida al momento de introducir la 'opresión' y la 'injusticia' como causa de la patología en el campo de la medicina, y ello también contribuye a la elaboración del concepto de Salud Colectiva y la sanidad de la población. Pero lo biológico, en esta mirada sobre lo social, continuó ocupando un lugar en la definición de la causa en psiquiatría. Como se mostró, ese es un perfil que envuelve a gran parte del continente y se extiende durante décadas en el siglo XX.

Hay una preocupación teórica por la relación patología y ambiente. Es en este marco donde adquiere sentido la publicación de trabajos extranjeros que, desde la eugenesia, el evolucionismo, higiene y la psiquiatría, discuten sobre ambiente y biología como elementos de explicación de la anomalía, como formas de comprender la historia, la higiene, la salud 
mental. El debate internacional eugenésico y psiquiátrico es presentado a través de la publicación de los trabajos de J. Solé Segarra, Javier Mariátegui, Juan Dalma y Vallejo Náguera en los Archivos de Criminología.

Encontramos aquí a Antonio Vallejo-Nagera, el psiquiatra de la dictadura franquista, cuya comprensión de la historia, la nación, la raza, el ambiente y la patología acabamos de revisar. Es presentado como Profesor Catedrático de la Universidad de Madrid. No hay un perfil breve sobre su labor como psiquiatra que dé cuenta de la relevancia que tiene su figura en ese país. La presentación del perfil profesional de quienes colaboran con esta revista es irregular. A veces consta. Otras ocasiones solo se informan la nacionalidad de quien colabora, en otras publicaciones solo consta el nombre de quien ha escrito sin que se sepa su formación profesional o nacionalidad. Su escrito es publicado en el volumen 1, número 1 de enero-marzo de $1953^{22}$ en los Archivos de Criminología. Lleva por título "Evolución Histórica de las Ideas Psiquiátricas Hispanas".

En el texto Vallejo construye un relato sobre el avance, en términos científicos, de varias de las teorías psiquiátricas, y apunta que aquello que denomina como "espíritu de la hispanidad" es el catalizador de progresos significativos de la terapéutica de las enfermedades psíquicas y de la asistencia de los enfermos mentales. Para Vallejo lo que se comprende por terapéutica y asistencia refleja el estado de evolución de las ideas científicas y filosóficas y, por ende, el aporte que una raza hace en el campo de las ideas. A partir de allí encuentra un origen fundacional de la psiquiatría que se corresponde con un pasado glorioso de España y Portugal. De las dos culturas destaca dos elementos con los que construye el argumento respecto del origen de la psiquiatría: la "Raza" y el "Humanismo".

Sobre la Raza manifiesta que españoles y portugueses descienden de la misma población que se ubicaba en "la península Ibérica antes de la dominación romana, alimentada por idénticas fuentes culturales; durante siglos Ciencia, Literatura y Arte, florecen en Portugal y España con características propias que la universalizan y hacen famosos a sus hombres."

\footnotetext{
${ }^{22}$ Por su entrada directa a la problematización de la raza, el hispanismo y la grandeza de un pasado español, deduzco que el texto es anterior a los 50's. Según Campos y Novella (2016), la derrota del régimen nazi suscitó en los 50's cambios retóricos en la psiquiatría española. La higiene mental se inclinó por un discurso más técnico y científico sobre la salud mental que no versaba ya en la determinación de los nexos entre estabilidad política e higiene, y dejaba en un segundo plano la represión y la higiene racial. Por otro lado, España se reincorpora a los debates e instancias internacionales como la Federación Mundial de Salud Mental. También, hay una preocupación por asegurar la Salud Mental de los normales desplazando el foco de la asistencia y la prevención de las psicosis que marcó anteriormente a la eugenesia, además se genera apertura al psicoanálisis y ello suscita el paso de la determinación de la causa de la herencia hacia lo psíquico. Ahora, la esencia histórica del español se presentaba de nuevo en el origen de los trastornos mentales, pero se presentaba con un cambio de discurso que se traslada de la recuperación de un pasado glorioso para conseguir la higiene mental, a la aceptación de una realidad distinta a la de siglos pasados. Para 1960 , año de la declaración oficial del Día de la Salud Mental, la psiquiatría española da muestras de un cambio más profundo aún, pues abandona su proyecto autárquico y se homologa al resto de países del entorno. La dictadura se modifica por la bonanza del desarrollismo y el Plan de Estabilización de 1959, y la psiquiatría se afianza en las cátedras universitarias (p. 81-84-85-86).
} 
(Vallejo-Nágera, 1953, p. 67). Por ello, portugueses y españoles forman una raza que no se constituye por "índices antropométricos ${ }^{23}$ " sino por características psicológicas y culturales fundidas en el cristianismo y "que forjaron el espíritu de la Hispanidad". Estas características permitieron, a castellanos y portugueses, compartir con otras razas "primitivas y salvajes la conciencia de la unidad moral del género humano" que les dio a todas las naciones la gracia para salvarse y que permitiría hacer de los "indígenas africanos y americanos iguales ante nosotros ante Dios, y los tratamos como hermanos." (p. 68).

Según Vallejo-Nágera estas características intrínsecas confluyen en el espíritu hispánico, cuyo ideal primordial es mejorar la condición del hombre. Ese ideal por la mejora del hombre es el que contribuyó al progreso de la ciencia. Esta herencia, que está inscrita en la raza hispana desde sus orígenes, le permite decir que esta tendencia ideal ubica al hispanismo como precursor del humanismo, y por ello, la asistencia desde el humanismo a los locos se halla en el hispanismo, no en Pinel. El fundamento de la ruptura de las cadenas de los locos y el tratamiento a su locura (mito fundador de la psiquiatría moderna occidental) según este psiquiatra, no está en Francia, sino en España y se encuentra presente antes de la conquista de América en el siglo XV. Por ello, la colonización implicó una forma humanitaria de llevar al indio ante Dios (p. 71).

De hecho plantea que el Manicomio de Zaragoza fundado en 1425 por el Rey D. Alfonso V de Aragón "atrajo la atención de PINEL, el reformador de la asistencia de los enfermos mentales en Francia, que le dedica elogios extraordinarios." (p. 72). El texto presenta un listado de personajes cuyo intelecto y obra son la prueba del adelanto de los españoles en psiquiatría. Así por ejemplo, Alberto Magno se habría adelantado seis siglos a Lombroso respecto de la explicación fisiológica de las alucinaciones visuales; la idea de las localizaciones cerebrales se habría desarrollado en ese país en 1551; Cervantes se habría adelantado tanto a la psiquiatría dinámica como a la teoría constitucionalista de Kretschmer, ya que en Don Quijote "adscribe a dos figuras corporales opuestas cualidades temperamentales diferentes." (p. 76). La culpa del estancamiento científico la deposita en las guerras civiles y el liberalismo.

Finaliza el texto refiriéndose a los retos que tiene la psiquiatría española frente a este 'estancamiento' en el que han decaído, proponiendo como el mayor de ellos el tener una

\footnotetext{
23 Aquí Vallejo-Nágera realiza un giro que se opone a la antropometría en la teoría de Galton. La particularidad de la raza, en este caso según Vallejo-Nágera, no se encuentra en las características antropológicas corporales que establecen diferencias raciales. Tampoco respondería a la Antropología criminal de Lombroso. Vallejo-Nágera coloca las diferencias en algo intangible como la cultura y la psique, dejando sin lugar la posibilidad de encontrar en el cuerpo procedente de un hibrido racial, de los españoles y portugueses, argumentos para clasificarlos y ubicarlos desde la teoría de Galton en una escala menor de la jerarquía de razas a través de la identificación y establecimiento de "los patrones de normalidad sobre los que [Galton] sustentaba la posición social 'científicamente' asignada a cada miembro de la sociedad. De ahí [el afán de Galton] por realizar mediciones antropométricas que se detuvieron especialmente en estudiar huellas digitales de simios y seres humanos, cuyas razas 'inferiores' las ubicó en un estadio intermedio entre aquellos y el individuo 'caucásico'.” (Vallejo y Miranda, 2005, p. 149).
} 
escuela propia de psiquiatría ibérica (portuguesa y española), unos objetivos y preocupaciones propias “y reconocido en sus valores universales.” (p. 87).

El texto fue escrito como un homenaje al centenario de la fundación del Manicomio de Bombarda, y podría interpretarse la publicación de este escrito en los Archivos de Criminología como una suma a ese homenaje, así como se puede advertir el deseo de difundir un trabajo académico que sirve como fuente de aprendizaje (y consulta) sobre el desarrollo de la psiquiatría según un autor de tanta valía en España, y con buena recepción en países como Argentina en donde el Dr. Julio Endara, director de los Archivos de Criminología, adquirió, según Landázuri (2008), conocimientos sobre Criminología en la década de $1930^{24}$ (p. 199).

Pero de la publicación de este trabajo puede extraerse otros sentidos. En primera instancia, Vallejo es una figura pública destacada en España, es el psiquiatra del franquismo y uno de sus más notables ideólogos. Vallejo es una "vos autorizada" (Bourdieu, 2001, p. 81) de la psiquiatría española. La represión, la dictadura, la simpatía o rechazo por el régimen español por parte del comité editorial de los Archivos de Criminología no está en discusión. A la hora de publicar a Vallejo, a mi juicio, lo que importa es su estatus de científico, la legitimidad instituida y reconocida de la autoridad de su voz que no solo lo enviste y reconoce como psiquiatra, sino también como voz autorizada de la historia de la psiquiatría. La genealogía que elabora para hablar de la "Evolución" de "Ideas Psiquiátricas Hispanas" comprende ese reconocimiento social. De allí proviene el peso de la publicación de su texto en una revista ecuatoriana especializada en psiquiatría.

${ }^{24}$ De hecho, Endara toma para Ecuador el nombre de la revista argentina Archivos de Criminología dirigida por José Igenieros entre 1902-1913. Durante su estadía de estudios en Argentina, en donde adquiere conocimientos sobre clínica criminológica, Julio Endara advierte la necesidad y los efectos prácticos de tener un espacio de producción científica en el cual plasmar el conocimiento psiquiátrico y a la vez difundirlo. Endara, durante largo tiempo fue partidario de muchas de las ideas de José ingenieros en torno a la raza. Por ejemplo, rescata sus ideas sobre la necesidad de elaborar inventarios científicos para tener una visión de la geografía y la historia de la nación en torno a la raza. Pero, es bastante claro (sobre todo en la década de los 40’s y 50’s) que toma distancia con las posturas más negativas de ingenieros en torno a los indios y al mestizaje. Podría suponer sobre este punto, a manera de hipótesis, que esta distancia responde a lo que cada uno de estos científicos podía asegurar en torno a su identidad. Ingenieros se podía ver y sentir europeo porque sus orígenes son esos, y desde esa identificación construye las diferencias raciales con los indios y perfila su postura sobre el mestizaje. En cambio la tensión entre la imaginación Hispanista de la identidad nacional y una Indo-americana promovida por un grupo de psiquiatras, entre ellos Endara, da cuenta de otro contexto sobre la construcción de la identidad nacional que responde a otro proceso histórico en el que Endara está inmerso y que conducen a que no pueda asumirse como heredero de la tradición europea, y se adhiera más bien a una imaginería que incorpora/desplaza al indio como parte del ser colectivo nacional. Otros intelectuales de la época, como Garcés y Cueva, adhieren a esta identidad en la que algunas posturas de Ingenieros ya no caben y serían contra producentes con ideal que se defiende. Y desde allí, desde esta identidad nacional se apuesta también por una producción teórica sobre la realidad racial del país en un contexto, además, en el que se han producido muchos cambios en América Latina. No obstante, la producción teórica implica una continuidad con el campo epistémico y político que termina por reproducir algunas de las formas raciales que se expresan en el campo médico, como la idea de progreso (tiempo moderno) frente a lo aún incivilizado. Sobre este último punto me extiendo en el capítulo cuarto y quinto. 
Vallejo-Nágera debió ser una de esas eminencias de la psiquiatría con las que Landázuri (2008) asegura que Endara se codea desde hace mucho y que se nota en la cantidad de colaboraciones extranjeras que tiene la revista y sus múltiples reconocimientos en el exterior (p. 244). La propuesta de tener una escuela propia debió resultar muy sugerente para el Dr. Endara, que desde la década del 30 encuentra de suma trascendencia hacer de la clasificación de las enfermedades mentales un lenguaje uniforme y compartido en Sudamérica $^{25}$. Pero no por sumarse al concepto de "Hispanidad", sino por la idea de unificar esfuerzos y homologar un lenguaje que permita una clara clasificación de la sociedad y a su vez que este lenguaje unifique saberes antropológicos, históricos, sociológicos, biológicos, psicológicos, estadísticos, etc. Un lenguaje para dar cuenta de todo.

Muestra de ello son las secciones de la revista "Libros" y "Revista de revistas" en donde comentan una vasta bibliografía internacional que da cuenta de un arduo trabajo de lectura que abarca una amplia diversidad de temas que van de los postulados de la Neurología hasta la literatura. Endara debió reconocer en el trabajo de Vallejo-Nágera este esfuerzo cuando el psiquiatra español asegura que entre los psiquiatras de su país predomina un "sano eclecticismo" (p.86) y que a diferencia de los psiquiatras franceses y de lengua inglesa que nada saben de la producción académica de otros países y continentes porque solo leen en su idioma, los psiquiatras españoles (y los ecuatorianos) agotan "la bibliografía nacional y extranjera" (p. 85).

Debió reconocer los propósitos de los psiquiatras ecuatorianos en la insistencia de VallejoNágera en formar psiquiatras que sean investigadores científicos, en la necesidad de fortalecer la cátedra universitaria en psiquiatría y tener sus propios espacios de observación, sus propias instituciones. Claro que este esfuerzo en Ecuador comprendió, según Landázuri (2008), una lucha por superar el encierro colonial a través del despliegue y propagación de un saber positivo, y no, como en el psiquiatra español, un esfuerzo por progresar recuperando un pasado glorioso de la psiquiatría ${ }^{26}$.

Si sigo la tesis de Landázuri sobre la superación del encierro colonial sumado al deber que el Dr. Endara advierte en formar psiquiatras eclécticos, podría agregar que la publicación del trabajo del psiquiatra español se enmarca en un interés por conocer la historia de la psiquiatría, sus fundamentos teóricos, sus objetivos. Pero el artículo de Vallejo-Nágera también podría tener función en otro sentido, en el de sostener que la psiquiatría ingresa, se extiende y avanzada en las culturas civilizadas que buscan el progreso de las naciones a través de la mejora de la condición de la vida del hombre. Por ello, la psiquiatría ofrece un

\footnotetext{
${ }^{25}$ Así lo plasmó en un artículo titulado "Clasificación de las enfermedades mentales y posibilidad de uniformarlas en Sudamérica”, publicado en 1937 en los Archivos de Criminología.

${ }^{26} \mathrm{Si}$ los psiquiatras ecuatorianos y latinoamericanos establecieron en algún punto y por alguna razón política o profesional una genealogía para el desarrollo de las ideas psiquiátricas no conexas a Europa, sino a otro pasado, ese es un estudio aún por realizar.
} 
trato y un tratamiento científico-humanístico a la locura, para Endara ese sería uno de sus principios rectores ya sea que el origen del humanismo está en Portugal, España o Francia.

Finalmente, considero que el texto adquiere un sentido más: la psiquiatría y la ciencia son importantes para el progreso de una nación y pueden aportar a su conocimiento histórico. Es más, puede generar un conocimiento histórico, y este conocimiento puede hacer de la raza una categoría de análisis que dé cuenta de su problemática, de su realidad psíquica y sus relaciones con la nación y el progreso.

Tres años después se publica en los Archivos de Criminología un trabajo del Dr. J. Sole Sagarra, Neuropsiquiatra del Hospital Clínico de Barcelona y Director Consultor del Instituto Psiquiátrico Pedro Mata de Reus en España. En este trabajo Sagarra argumenta las razones por las que la psiquiatría debe apostar por un conocimiento genético y preventivo sobre la raza y enfermedad mental, pues la

\footnotetext{
"genética moderna demuestra que no se heredan características patológicas o enfermedades, sino la disposición a padecerlas, concediéndose casi tanta importancia a la masa heredable (genotipo), como al factor ambiente (paratipo). (...) El hecho de la presencia constante del componente exógeno en la génesis de una enfermedad, por típicamente hereditaria que parezca, tiene trascendental importancia, pues deshace el inveterado dogma de la incurabilidad de todo proceso heredado, dogma fatalista que en psiquiatría condujo antaño al nihilismo terapéutico de muchos trastornos psíquicos. Hoy podemos decir que herencia no es igual a fatalidad, sino a destino amenazador.” (Sagarra, 1955, p. 209-210).
}

El peligro de la herencia desgraciada es, para Sagarra, el justificativo para la intervención eugenésica, ya que es intervención preventiva y es más "humanitario prevenir que curar". Ello sería, dice el autor, "esencial" para un Estado que se preocupe por la "potencialidad física y espiritual de sus ciudadanos", cuidando de la higiene mental y a través de ella prevenir la degeneración psíquica mediante la eugenesia (p. 210-211).

Citando a Luxenburger dirá que se debe considerar al medio ambiente como "verdadera causa genética, y no solo como simple factor desencadenante." (p. 214). También se debe tener en cuenta las "Intimas relaciones con la herencia [que] tiene la constitución psicofísica de un individuo y su raza, especialmente los tipos constitucionales y los tipos raciales. Ello justifica parcialmente el estudio de la higiene racial en el marco de la psicoprofilaxis, ya que las teorías constitucionales tienen actualmente quizás más importancia diagnóstica que profiláctica en psiquiatría por lo que deben estudiarse en los capítulos dedicados al diagnóstico psiquiátrico en general.” (p. 214-215). Entonces, en psiquiatría no sería tan relevante la profilaxis (cura) como la prevención de la degeneración de las razas "a base de medidas higiénico-científicas adecuadas a cada núcleo humano. Ello constituye la esencia de la higiene racial." (p. 215). Es decir, no tiene tanta importancia actuar sobre la manifestación de la degeneración como adelantarse a ella y evitar su manifestación psicofísica y su propagación social. De allí la importancia del estudio racial higiénico y diagnóstico de las razas y de actuar sobre la biología a través de la modificación 
y la acción sobre el ambiente, conductas, hábitos, comportamientos. Lo fundamental está en prevenir que el factor endógeno o genotipo que juega un papel etiológicamente importante y que no excluye ningún "síndrome psiquiátrico" pueda desencadenar la patología.

La profilaxis trataría entonces de construir un saber psiquiátrico sobre higiene racial con base en la genética, con el fin de obtener diagnósticos adecuados de la patología mental para así prevenir la degeneración racial a través de medidas eugenésicas adecuadas, como por ejemplo, promover la eugamia en lugar de la eutanasia o no permitir el matrimonio (léase procreación) entre enfermos mentales y así prevenir la "predisposición hereditaria a ciertas perversiones sexuales y antisociales como la homosexualidad y la delincuencia." (p. 216).

La publicación de la ponencia en representación de Argentina del Dr. Juan Dalma refleja aquellas tareas que la psiquiatría advierte en el IV Congreso Latino-Americano de Salud Mental y que los psiquiatras ecuatorianos asumen. La ponencia fue publicada en los Archivos de Criminología en 1958 y versa sobre la "utilidad y posibilidad" de contar con un "Censo psíquico integral de la población". El censo debe apuntar a ser un método estándar para dar cuenta del caudal psíquico de las naciones (p. 558), permitiría una mejor planificación urbanística en pos de un mejor "ambiente", es decir, la creación de un espacio vital psicológico.

Dalma considera que no se debe descuidar la probabilidad de que las "masas de color", al estar alejadas de las condiciones de círculo cultural occidental, puedan producir dificultades en la aplicación del censo por no responder a los estándares universales. Para responder a estas dificultades propone el uso de los test (entre ellos el de Rorschach) como técnica para captar los elementos del nivel mental y cultural general y comparativo de las poblaciones a través de los resultados que permite obtener sobre afectividad, ética y temperamento de la personalidad.

Además, propone la combinación de test de inteligencia y personalidad con el "zig-zag" (que permite medir el temperamento) para obtener resultados respecto de las "posibilidades potenciales latentes, en las capas más humildes y en las poblaciones aborígenes, comparándolos con aquellos de los test de inteligencia." (p. 568). Se trata entonces de investigar a la población a través del concepto de "densidad psicológica de la población", que es entendido como un nuevo factor "biosocial y demográfico" para la "captación psicométrica integral y comparativa de la población mundial, por regiones y estratos sociales, etc., bajo el aspecto intelectual, emotivo-temperamental, cultural y ético, reconociéndose las dificultades, debidas a la escasa madurez operacional de nuestros actuales medios de investigación en este campo." (p. 569).

La preocupación eugenésica extranjera por el ambiente sigue resultando importante en la década del 60's para la psiquiatría ecuatoriana. Muestra de ello es el trabajo presentado por 
Javier Mariátegui al V congreso Latinoamericano de Salud Mental, Caracas-1963, y publicado en los Archivos de Criminología dos años después. Tras hacer un recuento sobre la controversia Herencia vs. Medio, insiste en que el medio tiene tal incidencia en la salud, la enfermedad y en la misma genética, que incluso la puede modificar. Con el fin de reestructurar la eugenesia, divide sus tareas en dos partes, dos órdenes de acción preventivos: una eugenesia positiva (ambiente) y otra negativa (herencia). La tarea no consistiría en optar por herencia o ambiente, sino comprender los dos aspectos. Retomando la tesis de Luxemburger de que "la herencia no es destino sino amenaza de destino", Mariátegui postula que

de un lado, medidas estrictamente genéticas, enderezadas a prevenir, o por lo menos a disminuir la aparición de individuos con carga genética indeseable, evitando la reproducción del fenotipo morboso, (eugenesia negativa); de otro lado, medidas ambientales encaminadas tanto a evitar la exteriorización aparente o manifiesta (fenotípica) de las enfermedades de raíz germinal, cuanto a la acción sobre lo ecológico para evitar el modelo defectuoso del individuo genéticamente bien constituido y propender al aumento de los individuos aptos (eugenesia positiva), (...) En una formulación sintética, la eugenesia debe comprender pues dos órdenes de acciones: eugénicas propiamente dichas (sobre los factores hereditarios) y, por obligada extensión, euténicas (sobre los factores ambientales). (Mariategui, 1965, p. 155-156).

Al igual que Sagarra años antes, Mariátegui insiste en la incorporación de la genética al ejercicio psiquiátrico, para iniciar un programa que no se ocupe solo de la enfermedad mental, sino que para entenderlas hay que explorar primero la genética de la salud mental y luego la genética de la enfermedad que tiene mayor o menor grado de incidencia. Insiste en que evitar la reproducción del fenotipo morboso a través de la esterilización no es útil como procedimiento eugénico preventivo de las enfermedades mentales. Por el contrario, el "consejo eugenésico" es la "medida eugénica de mayor aceptación, que no vulnera principios religiosos, que no genera resistencias sociales, ni obliga a la discusión sobre el problema filosófico de la libertad humana (...)" (p. 168). Pero el consejo eugenésico solo debe actuar como consejo orientador y no legal.

Finalmente lamenta que las resistencias y las sospechas de los movimientos sociales sobre los propósitos de la eugenesia, que sostienen sus razones en lo que había generado la perversión "de las teorías genéticas durante el nacismo", haya conducido a negar la influencia de los factores genéticos por considerarlas "no democráticas" o "reaccionarias" (p. 172). Para contrarrestar esta resistencia aboga por entender el propósito de la eugenesia que se resume, según Mariátegui, en una cita que hace de Eliot Slater: "el progreso eugenésico debe ser un fundamental designio humano regido siempre por un respeto a la libertad individual y la autodeterminación, y deberá lograrse por persuasión y educación del público a los valores biológicos y no mediante legislación opresiva." (p. 173).

Aquí se resume el propósito que pareciera pretende asumir la eugenesia de la posguerra: la apuesta por los "valores biológicos", más no, señala Mariátegui, por la politización de 
Darwin que derivó en su distorsión por la que llegó a considerarse que la desigualdad es condicionada por razones hereditarias (p. 172). Los "valores bilógicos" aluden a que se trata de la supervivencia de los pueblos frente a la amenaza de los riesgos "de un gradual incremento de los individuos pobremente adaptados con mayores posibilidades de reproducción, como consecuencia directa de los progresos de la medicina [y por un] incremento ulterior en el porcentaje de mutaciones debido al uso excesivo de radiaciones ionizantes. (...) Las consecuencias adversas para las futuras generaciones pueden ser de tal grado que la supervivencia de las poblaciones se vea amenazada. Es pues este problema general de salud pública que obliga a la adopción de medidas generales para prevenir estos riesgos." (p. 173).

Si la eugenesia es un asunto de salud pública, es un asunto de Estado y concierne a toda la sociedad. Y debe lograrse su adquisición, aplicación, propagación, práctica, difusión de los valores bilógicos a través de la persuasión y la educación, y no ya de la represión. Para eso sirve el consejo eugenésico. Pero el consejo, además de ser orientador, deduzco, debe convertir los valores futuros (los "valores biológicos") en valores comunes de defensa de pueblos. La psiquiatría eugenésica, en esta perspectiva, vela por la salud de las poblaciones. Ese sería su rol en la historia de las naciones. Y como vimos en el capítulo primero, es un rol nada alejado al que asume la medicina en la primera mitad del siglo XX en Ecuador.

Los valores biológicos son una concepción psiquiátrica biológica de la temporalidad que apuesta por un futuro saneado por una profilaxis ambientalista, biológica y preventiva (que se ocupa del futuro observando el pasado genético) en pos de un presente social que garantice las condiciones "biosociales y demográficas" para la salud mental de las poblaciones. El hiato en los valores biológicos sostenidos y propagados por la educación, la persuasión y la prevención como vías de arribo a un futuro social y biológico ideal, marcan parte de la tónica de la narrativa que produce el "campo de visibilidad" psiquiátrico. A su vez, convoca un esfuerzo grupal, un horizonte de expectativas con el que se identifica toda una comunidad científica que al reunirse en Congresos internacionales discuten la vía más adecuada para diseñar y convenir métodos de estandarización del presente psicológico, ya no solo para alcanzar la higiene mental, sino la salud mental y biológica de las poblaciones del futuro. 
CAPÍTULO 4 


\section{4.- De la producción psiquiátrica en Ecuador}

Sobre los Archivos de Criminología Neuropsiquiatría y Disciplinas Conexas, Órgano del Instituto de Criminología, la única revista de larga data especializada en Psiquiatría en Ecuador, no se ha escrito un trabajo específico así como tampoco de la relación Crimenpsiquiatría como parte de la historia ecuatoriana. La revista, es comúnmente una fuente de diferentes consultas, pero no un objeto de estudio. Sin embargo, Mariana Landázuri Camacho, en su abordaje histórico sobre el Hospital Psiquiátrico San Lázaro, titulado "Salir del encierro", recaba una gran cantidad de datos sobre el origen y la evolución de la revista. Este capítulo por entero se remite al mencionado trabajo de Landázuri, y es escrito a través de sus valiosos aportes.

Pero, cabe aclarar que no voy aquí en busca de la historia de un producto cultural. A través de la producción en los Archivos de Criminología, voy en busca de los vehículos de visibilidad y aprehensión del campo conceptual psiquiátrico con el que estos profesionales definen sus objetos de saber; voy tras las condiciones (grado de desarrollo teórico y técnico) con las que establecen reglas para la constitución, aprehensión e inteligibilidad del objeto al que delimitan; voy tras el sustento de una expectativa, de un modelo de explicación de lo real.

\subsection{Descripción de los Archivos de Criminología Neuropsiquiatría y Disciplinas Conexas, Órgano del Instituto de Criminología en torno a su preocupación por la raza}

A mediados del siglo XX, cuenta Landázuri (2008), un grupo de reconocidos psiquiatras, ve concretarse un anhelo que varias generaciones persiguieron desde inicios del siglo: la inauguración de un hospital moderno en el sector de Conocoto, ubicado en los valles de la ciudad de Quito, que años después llevará el nombre de Julio Endara, en honor a uno de los más prominentes doctores y psiquiatras del Ecuador, quien murió en la década del 60 y desde 1936 fue editor y directo de la revista en mención. Uno de los objetivos centrales de la construcción de este hospital sería llevar a la profesión y a los locos fuera de los muros del encierro colonial con el que debieron lidiar por medio siglo. Un objetivo humanista. $\mathrm{O}$ al menos esa sería su postura frente al pasado para instalar la necesidad de un hospital moderno en el presente.

Desde sus inicios, los médicos y psiquiatras ejercieron en el Hospicio San Lázaro, activo como edificación desde 1785, allí encuentran el dominio colonial desplegado e impreso en la cotidianidad de sus habitantes que viven una realidad nada digna y deplorable. Con el triunfo de la Revolución Liberal en 1895 al mando de Eloy Alfaro, el país se encamina en un proceso de secularización del Estado. Ello beneficia tanto el desarrollo de la psiquiatría como sus propósitos, pues marca el inicio de un nuevo momento para la ciencia. Es un momento de quiebre en el siglo $\mathrm{XX}$ donde los escenarios políticos e institucionales se reconfiguran en medio de disputas por el dominio del Estado y el monopolio por los 
sentidos sobre lo social. El proyecto laico que se inicia aquí y que marcaría una definitiva ruptura con el "Concordato", permite el advenimiento de nuevas élites intelectuales así como la cabida de nuevas disciplinas y nuevos discurso sobre lo moderno y lo científico, discursos desde donde se produce nuevos sentidos sobre lo real y nuevas formas de delimitar lo que pertenece al pasado y al presente.

Desde la Revolución Liberal en "adelante", el Estado laico pasa a ser una línea divisoria entre un tiempo y otro, entre una forma de determinar lo moderno y lo científico frente a lo que no es moderno o científico. La emergencia de la psiquiatría está aunada a esta ruptura. Los médicos psiquiatras pasan a formar parte de una nueva élite intelectual que tiene diálogos directos con el poder político y económico del país para realizar y posicionar sus preocupaciones, intereses y demandas profesionales. La posibilidad de construcción de un Hospital moderno y acorde a los requerimientos científicos forma parte de estos diálogos. Y parte de los argumentos con los que se persuade sobre la necesidad de la construcción de dicho Hospital, versan sobre las distancias temporales que los psiquiatras elaboran respecto de un pasado colonial y conservador, y un presente moderno.

Gracias a esta ruptura entonces, el proyecto de un Hospital moderno se concreta en 1953. La inauguración del Hospital Psiquiátrico de Conocoto figura como una de las más grandes conquistas de las ciencias modernas. Es el espacio presto para el ejercicio moderno de la psiquiatría, el espacio en el que aconteció, según Landázuri, un cambio de paradigma que la autora resume como el paso del encierro colonial al internamiento médico psiquiátrico. Internamiento que es asumido como humanista.

Su construcción suscitó un uso social de la distancia temporal para diferenciar un antes y un después, un presente, un pasado y un horizonte de expectativas de la psiquiatría moderna en relación al tratamiento de la locura. En 1930, tras un primer anuncio de la posibilidad de construcción de un nuevo hospital psiquiátrico, el Dr. Alberto Correa, antiguo profesor de Psiquiatría de la Universidad Central del Ecuador y, en ese entonces, director del Hospital Civil de San Juan de Dios, escribe en el Boletín del Hospital (Órgano del Cuerpo Médico del hospital) lo siguiente:

La Honorable Junta de Asistencia Pública, impulsada por los más nobles sentimientos humanitarios, ha decidido, por fin, iniciar la construcción del nuevo manicomio, en el fundo del Rosario situado en el vecino pueblo de Cotocollao; y nosotros, entusiasmados con la sola enunciación de la idea, que equivale a ver lucir -siquiera en lontananza- la tranquilidad, la alegría y el bienestar, para los infelices locos, que en el actual manicomio ${ }^{27}$ carecen de un rayo de sol; sol que, según el decir de Falcmarión 'es el padre de la vida', no podemos menos que aplaudir, con todo el entusiasmo de

\footnotetext{
${ }^{27}$ Se refiere al Hospicio Manicomio San Lázaro, donde fueron encerrados todos los sujetos que habitan el lugar de la miseria. Es la patria común del otro colonial (Sánchez, 2005): negros, indios, leprosos, prostitutas, infieles, alcohólicos, pobres, vagabundos, locos, huérfanos y ancianos. Ubicado en pleno centro de la ciudad, en el casco colonial, a pocos metros del palacio de gobierno. La presencia de sus habitantes no deja de ser inquietante y estorbosa para la población quiteña (Landázuri, 2008) que no deja de clamar por su expulsión del centro de la ciudad. Este clamor será determinante tanto para los gobiernos como para los objetivos políticos y disciplinares de la medicina psiquiátrica en el S. XX.
} 
nuestro corazón, tan humanitario proyecto. Y como no hemos de aplaudirlo, si, hace quince años, fuimos nosotros los primeros en llamar la atención del público y las Autoridades, hacia este punto tan impostergable y en el que, hasta hoy, hemos procedido contra los sentimientos de caridad fraternal que debían existir en el corazón de todos los quiteños? (...) pero, para dar cuenta de lo que allí se padece, haremos conocer las palabras con que un enfermo nuestro, muy inteligente, y a quien nos vimos, hace poco, en el caso de asistir en él, nos decía, cuando recuperó la razón: 'Es tanto lo que en el Hospicio se padece y tan crueles los tormentos de los pobres dementes, que, si hoy, después de que he vivido en esa mansión de dolores, quisieran sepultar en ella a una persona querida de mi familia, aunque yo creo en la existencia del infierno, antes que consentir en ello, le pegaría un balazo y me pegaría otro después, porque solo en tan horrendo lugar de castigo puede padecerse tanto como en Hospicio de Quito!' Bien comprendemos la exageración con que habla nuestro enfermo, ya que era un hombre que aún tenía demasiada excitabilidad en su sistema nervioso y conservaba todavía en su retina la imagen de los cuadros que acababa de presenciar; pero, descontando lo que tenga de hiperbólica su pintura, nadie, que haya salvado los umbrales de esa prisión de locos dejará de reconocer que fueron construidas de acuerdo con las ideas en el mundo hace cosa de 140 años, antes de que Pinel, el insigne médico -alienista francés, de potente cerebro, y más potente y noble corazón, consiguiera hacerse oír de las autoridades de Francia- para que su reforma repercutiera, después, ventajosamente en todo el mundo- alcanzando que se elimaran las cadenas de los locos de 'La Salpetriere y de Bicetre' y se emplearan, para tratarlos los medios de sagacidad y dulzura, en lugar de los brutales de tiempos anteriores.

La tensión entre pasado y presente en el uso temporal que expone Correa dibuja aquí un orden moral para el futuro que opone un humanismo psiquiátrico a un encadenamiento colonial. Un pasado colonial en oposición a un presente moderno humanista, heroico y ejemplar que da valor y función a la lucha por la fundación del nuevo manicomio. El pasado ecuatoriano en esta cita aparece como una especie de puente, en la medida que un pasado colonial andino es asimilado al pasado europeo anterior a Pinel. Pareciera que el pasado ecuatoriano es indistinto al francés y, como si ambos países compartieran las mismas luchas y se inscribieran en las mismas continuidades. Como si cargasen con las mismas mitologías sobre la locura, con las mismas prácticas, la misma racionalidad y los mismos "nobles sentimientos". Es esta asimilación al pasado europeo, sobre todo francés, la que pareciera, a ojos del Dr. Correa, insertar, en el presente, las luchas modernizadoras de los psiquiatras ecuatorianos en la mundialización del modelo pinneliano.

En el Dr. Correa se devela la identificación con las temporalidades que se desprenden del mito fundador de la Psiquiatría Moderna: la ruptura de las cadenas de los locos por Pinnel en La Salpetriere. El doctor Correa ata ese propósito y a esa lucha de Pinnel los ideales, las luchas y propósitos de los médicos ecuatorianos para superar el pasado colonial andino, que según el Dr., dio paso a la edificación de San Lázaro de acuerdo a "las ideas en el mundo hace cosa de 140 años" antes de Pinnel. Los médicos ecuatorianos entonces, habrían captado e incorporado bien el modelo moderno de Hospital y de tratamiento de locos, lo cual, en esta distinción de modelos y temporalidades, justificaba su urgente construcción.

Ello no quiere decir, por supuesto, que la situación de los locos en San Lázaro no haya precaria. De hecho lo era, su situación en momentos resulta inenarrable, y a pesar de las 
miles de mejoras que surgen con el paso de las décadas, me atrevo a decir que no superó por completo la precariedad hasta el cierre definitivo de este Hospital en el 2012. Lo que se plantea aquí es que la situación de los locos dentro del Hospicio, en las enunciaciones de los médicos, pasa a ser un elemento para la elaboración de la narrativa sobre el pasado y que da sentido a su lucha y, a la vez, caracteriza el pasado y marca límites identitarios con el presente.

Ahora bien, Landázuri (2008) señala otra fecha y otra inauguración de suma importancia para el desarrollo de la disciplina y que antecede a la inauguración del moderno Hospital Psiquiátrico. En este proceso de desarrollo de la disciplina, "el Estado ecuatoriano hace su mejor esfuerzo, en medio de la completa inestabilidad política de esta década [la de 1930], al apoyar la labor de Endara. Él acaba de regresar del muy europeo Cono Sur y quiere iniciar en su tierra lo que ha visto allá. En 1936 crea el Instituto de Criminología, dependiente del Ministerio de Gobierno, aunque poco después pase a ser una dependencia de la Facultad de Jurisprudencia de la Universidad Central" (Landázuri, 2008, p. 199). Los Archivos de Criminología Neuropsiquiatría y Disciplinas Conexas, son creados tras la inauguración del Instituto de Criminología. En adelante, es la revista del Instituto en la que se despliega todo el saber adquirido así como las investigaciones que llevarán a cabo.

Al encontrarse conexa al Instituto de Criminología y no sólo al Hospital Psiquiátrico, los trabajos publicados no se enfocan solo en la clínica o en las experimentaciones que se llevan a cabo en el Hospital, sino que se ocupan de la población carcelaria y de toda la sociedad. Implica un campo de intervención más amplio. Un años después de inaugurado el Instituto de Criminología se publica resultados de investigaciones. Según Landázuri, los Psiquiatras han adoptado una tesis muy influyente en el mundo, proveniente del antropólogo italiano Cesare Lombroso, que postula que el crimen responde a un fenómeno biológico de degeneración. La adopción de la teoría de la degeneración aplicada a la Antropología Criminal, dice la autora, conduce las primeras investigaciones ecuatorianas hacia la Psiquiatría forense: se mide el peso, la talla y se realiza descripciones de la constitución y tipología de los sujetos que se estudia (p. 200).

Tras un examen de los Archivos de Criminología se ha podido constatar que en la década del 30, Lombroso pasa a ser el antecedente genealógico de la explicación del funcionamiento de la psique a través de la Constitución y las tipologías, y no es del todo la teoría predominante en psiquiatría como lo afirma Landázuri. Quizá en las Historias Clínicas la presencia de Lombroso sea mayor y por ello Landázuri asegura que los psiquiatras han adoptado la teoría de la degeneración de la Antropología Criminal. Pero en mi revisión, desde que inician las publicaciones de la revista, los psiquiatras optan por la teoría de la Antropología Endócrina. De allí la presencia constante de Kretschmer, cuya Teoría Constitucionalista y método tipológico les resulta a los psiquiatras una vía más sofisticada para pensar el pasado, la raza, la nación y la constitución de sus sujetos, y en la 
anormalidad o la normalidad del indígena. Éste será un movimiento que recurre, en parte, a un modelo Genéticoconstitucional, derivado de la unidad de la Eugenesia con la Teoría Constitucional. Y como veremos, el psicoanálisis también entra en escena en la narrativa de la psique indígena y nacional.

Julio Endara (1954) muestra su adherencia al modelo Genéticoconstitucional al reseñar "LA DIRECTRIZ GENETICOCONSTITUCIONAL PSIQUIÁTRICA" de José Solé Sagarra. Endara, respecto a la unidad que Solé Sagarra hace en su trabajo de la profilaxis eugenésica y la Teoría Constitucional de Kretschmer, destaca los siguientes párrafos, que son para Endara un referente importante para comprender la raza desde la psiquiatría, al biotipo, la herencia y a Latinoamérica:

La importancia del medio externo en la herencia de las enfermedades psíquicas tiene enorme trascendencia, puesto que deshace el falso dogma de la fatalidad hereditaria. Además, contra el medio externo podemos luchar profilácticamente, por lo que la herencia no es ya fatalidad, sino solo destino amenazador. La exclamación de Pfahler en 1936, que sirvió de título a su valioso libro 'Warum Erziehung, trotz Vererburg?' (Educación a pesar de herencia?), hoy puede contestarse rotundamente: Sí, educación y profilaxia en sentido amplio, para modificar favorablemente toda herencia morbosa, actuando sobre el fenotipo a través del paratipo'.

Sobre la tipología de Kretschmer resalta el siguiente párrafo:

'Solo aisladamente se han comprobado en España las teorías constitucionales de Kretschmer, echándose de menos en nuestra raza la comprobación sistematizada de los principales puntos de las tipologías. Los psiquiatras españoles estamos acostumbrados a valorar el tipo corporal del enfermo que exploramos, habiendo comprobado prácticamente las afirmaciones de Kretschmer. En la raza hispana, el pícnico y el leptosomo tiene características psicofísicas equiparables a los del resto del mundo. En cambio, el tipo atlético en España no abunda tanto ni es tan rico en matices constitucionales como en el Norte de Europa y en Norteamérica. Nuestros ciclotímicos son en conjunto más alegres que los del Centro y el Norte de Europa, y nuestros esquizoides no son tan complicados como allí.'

Y refiriéndose a lo dicho del tipo corporal en España, Endara (1954) dice: "Afirmación que también la hemos comprobado en América Latina”, y concluye (p. 169). Es decir, "nuestros" pícnicos, leptosomos, esquizoides y ciclotímicos ni son tan complicados ni son tan tristes como en Europa y Norteamérica. Encontramos aquí empatadas la Teoría constitucional con la profilaxis eugenésica en el abordaje genéticoconstitucional de la raza, la psique, la herencia y el ambiente. Y es gracias a ese ensamblaje teórico que Endara se ve en la posibilidad de advertir y asegurar estas diferencias culturalesgenéticoconstitucionales en los biotipos de uno y otro continente que le ayudan a perfilar una imaginería sobre el "nosotros" en oposición a las características de los biotipos europeos y americanos. A ello Endara agrega un par de herramientas teóricas más como el Psicoanálisis, cuya adopción podría resultar sorpresiva (y quizá disruptiva) en un campo 
aún tan marcado por el positivismo; sin embargo, en este punto de extensión de la modernidad en el Ecuador, estos campos no se repelen, por el contrario, la adopción del Psicoanálisis permite completar el marco conceptual con el que Endara aborda la complejidad que tiene en frente. Si con la Antropología Endócrina indaga sobre aspectos biológicos de la raza, la herencia y el ambiente, con el Psicoanálisis busca calar en lo más hondo de la psique individual, y de allí, encontrar rasgos generales extensivos a la población en su totalidad. Veamos.

Los Archivos de Criminología, en la solapa, anuncian ser una publicación mensual. No es algo que se logre cumplir siempre, por distintas causas, la principal, según Landázuri (2008) es el factor económico con el que los psiquiatras tendrán que lidiar, a pesar de ocupar el lugar que ocupan en un proceso de secularización del Estado, que según esta autora, adopta al positivismo como el discurso que diferencia desde inicios del siglo al liberalismo de los conservadores y la iglesia (p. 210). Una forma bastante particular de diferenciarse, tomando en cuenta que en el círculo de los conservadores hay muchos personajes de ciencia y que el positivismo, como vimos en el capítulo 3, es uno de los pilares de construcción del Estado ecuatoriano y la Modernidad Católica desde el Concordato. La adopción del positivismo, cuya influencia está muy extendida en el mundo, seguramente permite dotar al ejercicio clínico y a los trabajos publicados en Los Archivos de Criminología de un carácter de verdad y universalidad.

Estamos aquí más bien frente a un uso social del tiempo como herramienta diferenciadora, a esa forma binaria moderna con la que se establecen distancias temporales. En este caso se marcan distancias temporales desde el positivismo impulsado por el liberalismo frente a un positivismo que no es visto como tal, sino más bien que es tachado de conservador. Muchos de los científicos que pertenecen al ala conservadora, señala Landázuri, son extranjeros, considerados positivistas y modernos en sus países de origen, ellos mismos se identifican como tales. Pero frente a la psiquiatría abalada por el liberalismo, forman parte de un pasado al que se oponen.

La adopción del psicoanálisis (que desde la década del 30 se encuentra bastante extendida en la práctica psiquiátrica) quizá, por sí sola, no dota precisamente a la clínica y a los trabajos de investigación publicados de un carácter de verdad y universalidad, pero estar a la vanguardia de los métodos y teorías más destacados de Occidente sí. Además, como veremos más adelante, forma parte de una forma de constitución del objeto histórico. En este sentido, la influencia del psicoanálisis en la psiquiatría ecuatoriana es bastante notable, desde las preguntas que Julio Endara realiza en la década del 30 "sobre el embarazo de la madre del paciente o hasta cuando lactó el niño” (Landázuri, 2008, p. 207), pasando por la importancia que tiene para éste y muchos otros psiquiatras la asociación libre en el Test de 
Rorschach a mediados del siglo XX y los homenajes póstumos a Freud en un número de la revista, prácticamente dedicados a él ${ }^{28}$.

Además, cabe mencionar que para la década del 30 hay psiquiatras formados en psicoanálisis, y que más tarde aplicarán esta teoría en el ámbito de la clínica, como es el caso de Jorge Escudero Moscoso, un médico psiquiatra de mucho prestigio y clave en la historia de ésta disciplina en el Ecuador. Según Landázuri, el Dr. Escudero aplica en aquel entonces terapia psicoanalítica de diván (p. 230). Escudero se formó en París gracias a una beca otorgada por el gobierno Liberal que le permitió, entre otras cosas, ser alumno de Ana Freud (214). De todos modos, el Psicoanálisis en las publicaciones de los Archivos de Criminología ocupa un lugar de momento periférico en relación al positivismo. Y no me refiero al número de publicaciones especializadas y diferenciadas en psicoanálisis o en positivismo, sino a su uso. Se puede encontrar trabajos (como los de Enrique Garcés y Julio Endara) que inician con inquietudes teóricas psicoanalíticas o que parten de métodos proyectivos, pero que derivan en conclusiones positivistas (Ver capítulo 5). El psicoanálisis en los Archivos de Criminología, y sobre todo en las fuentes que estamos revisando, es parte del marco conceptual, no una especificidad, ni un campo, ni una institución de saber. Pero en otros estudios de los psiquiatras sí tiene más presencia ${ }^{29}$, y al parecer también en la consulta privada, de la que por ahora no se puede dar cuenta.

Pero no hay una distancia rígida entre una y otra postura. Ambas marcan la pauta de lo nuevo y se amalgaman en un modelo de análisis. Es algo que se refleja tanto dentro de San Lázaro como en las publicaciones de la revista. Los tiempos del saber son distintos que los de la práctica: mientras que en la revista los objetos de saber de la psiquiatría continúan en definición multidisciplinar y evolución entre la década del 30 y $50^{30}$, los psiquiatras que se identifican ya como modernos, oscilan en una práctica que va de la aplicación de métodos considerados vanguardistas como el psicoanálisis a terapias bastante rezagadas como "los purgantes drásticos o las inyecciones de trementina que aplican en los muslos del enfermo. Estas inyecciones producen un absceso y la elevación de la temperatura del paciente." (Landázuri, 2008, p. 207).

Ahora bien, es notable que la definición de los objetos de saber psiquiátrico en las revista responde a una búsqueda ecléctica que conjuga, como vemos, varias vertientes de estudios del comportamiento. Eso se nota en la cantidad de bibliografía diversa que reseñan en cada número. Además la inteligibilidad de la patología mental, objeto de conocimiento que, según Osorio (2014), la Psiquiatría ha reclamado para sí desde inicios del siglo XX y con la

\footnotetext{
${ }^{28}$ Véase la sección de "Publicaciones originales", en Archivos de Criminología, 2da. época, Vol. 4, N 14, Abril - Junio de 1956, p. 163 - 208.

${ }^{29}$ Véase por ejemplo el libro "Semblanzas biotipológicas" del Dr. Agustín Cueva Tamariz, publicado por el Colegio Nacional "Benigno Malo", Cuenca-Ecuador, 1944.

${ }^{30}$ Incluso, me gustaría agregar que esta definición multidisciplinar dura hasta la década del 70, época en la que la revista toma un giro tras la muerte de su precursor, Julio Endara, para especializarse en criminología, neurología y una psiquiatría desatada de los aportes de la filosofía, la sociología, la historia, la psicología, y la antropología social.
} 
cual se han diferenciado del resto de especialidades médicas, y con la que se constituyen como sujetos modernos, responde a mi parecer a una intención multidisciplinar por definir sus objetos de conocimiento. La práctica, por la premura y las deficiencias del Hospital, a veces aparece más rezagada y menos elaborada que el marco conceptual con el que se trabaja en los Archivos de Criminología. Lo multidisciplinar quizá no es visible en la práctica dentro del Manicomio, pero fuera de éste, desde mediados de la década del 30,

(...) la que empieza a tomar fuerza es esta vertiente legal de la Psiquiatría que enlaza lo criminológico, lo psiquiátrico, lo jurídico y lo antropológico. No se ha hecho antes en el país y la revista del Instituto de Criminología es una excelente vitrina para desplegarla. La empujan los discípulos y colegas de Endara que hacen investigación en las cárceles, en la clínica privada que al final de esta década funda el profesor, y escasamente en el Manicomio San Lázaro. Es un fuerte liderazgo médico en el área académica que exige estar al día en materias que van más allá de los que la formación universitaria requiere. La envidiable multidisciplinariedad que los médicos han alcanzado les lleva a ser rectores del pensamiento y autoridades naturales ante la sociedad. Contribuye a ese la falta de otros profesionales (sociólogos, psicólogos, antropólogos, entre ellos), pero también la exigencia de la lacerante realidad nacional a la que se ven expuestos." (Landázuri, 2008, p. 205-206).

Si bien la práctica al interior del manicomio es bastante contradictoria respecto de la actualidad de sus objetos fuera de ésta institución, lo que refleja la revista aquí es un horizonte de expectativas: establecer una relación entre crimen y Psiquiatría a través del enlazamiento de la criminología, lo jurídico, lo antropológico y la patología mental, y que es el marco teórico en el que surge una preocupación por comprender "el ser nacional desde lo psíquico" (Landázuri, 2008, p. 208) y por hacer de la raza y el mestizaje un objeto de saber psiquiátrico. A ello se adhiere en los años 40, un contexto social de "resquebrajamiento del orden simbólico" (Polo, 2002) de la nación tras la derrota en la guerra con el Perú, y que influirá en la definición de lo nacional y la raza desde lo psíquico.

El trabajo inicial con el que se anuda la relación entre crimen y Psiquiatría, es el trabajo inaugural de la revista en 1937, y en éste versa contenido sobre la inteligibilidad de raza y nación en la práctica clínica. Criminología y psiquiatría: el enlazamiento entre eugenesia, higiene, psicoanálisis, jurisprudencia, patología mental, y antropología endócrina. Un campo de visibilidad que conjuga un saber proveniente del influjo positivista europeo y americano, pasa a ser una forma de institucionalización científica de un relato sobre la raza y la nación en Ecuador, antes del reclamo del folklore por parte del Estado a través de su objetivación antropológica en los años 60's.

Sobre lo dicho, tomo en cuenta que recién a mediados del siglo $\mathrm{XX}$, tras una apuesta del Estado Central y de las políticas desarrollistas de la región, el folklore es institucionalizado en el país. El registro de tradiciones, música, leyendas, conocimiento y reinvención de técnicas ancestrales pasaron a ser las constantes de la práctica antropológica tras la creación 
del Instituto Ecuatoriano del Folklore (1960) y el Instituto Azuayo de Folklore (1966). Con este impulso, el estudio del folklore pasa a ser una rama de la antropología en la década de los 60's y de imaginería de la nación a través del dibujo, la fotografía y elaboración de fichas de trabajo con la que se configuró una "diferencia cultural amparada en la noción científica de “investigación de campo'.” (Des-marcados, 2018).

Julio Endara (1937) inaugura la discusión psiquiátrico-criminológica en los Archivos de Criminología sobre los modelos de investigación científica del delincuente que se realizaba "por primera vez en el país" (139). Por ello, en el trabajo titulado "La historia de Clínica Criminológica", Endara, considera que el "primer trabajo debía dedicarse a la elaboración de un modelo de Historia Clínica Criminológica." Adopta el modelo de Criminología elaborado por el Profesor Oswaldo Loudet ${ }^{31}$, quien durante la dirección del Instituto de Criminología de la Penitenciaria Nacional de Buenos Aires en 1927, diseña un “perfeccionamiento de 'Boletín Médico Psicológico' de José Ingenieros. El modelo argentino ha sido adoptado también en el Uruguay, Colombia, Bolivia y Chile.” (p. 139).

No obstante, entiende que tal modelo de Historia Criminológica debe contemplar modificaciones acorde a los resultados que se espera de las investigaciones y a la realidad del país. Por un lado apuesta enfáticamente a que "mientras más se ahonde en las investigaciones constitucionales, más accesible será para nosotros el intrincado psiquismo del delincuente"; por otro lado señala que "al realizar una investigación en nuestras organizaciones penitenciarias, nos interesa aprovechar el abundante material para tratar de orientarnos en las diferentes características raciales que integran la nacionalidad ecuatoriana." (p. 139). Las negrillas son mías.

La ciencia para Endara ofrece una vía hacia la verdad del crimen y la raza a través de datos cuantificables, y teoría de la constitución con la cual llegar a lo profundo en la psique. Además, considera que en el sistema penitenciario se halla una clave para caracterizar y comprender la complejidad de la nación en torno a sus características raciales. No se trata solo del crimen, el horizonte de expectativas psiquiátricas implica una aspiración normalizadora, en tato que clasificada, de las "características raciales" del Ecuador.

Pareciera existir, en estas palabras, una "declaración", como si Endara considerase y dijese: los psiquiatras somos científicos, representantes de los nuevos tiempos y como tales debemos dar cuenta del todo, y por supuesto dar una respuesta sobre la realidad de la nación. Para ello, es necesario que elaboremos y adaptemos (perfeccionemos) los métodos de análisis clínico que poseemos, ya que tenemos frente a nosotros no solo el deber de actuar como científicos inaugurando un trabajo de investigación científica sobre el delincuente, tenemos además frente a nosotros otro objeto, otro desafio, un peso que

\footnotetext{
${ }^{31}$ Médico Argentino, impulsó la carrera de Medicina Legal, Medicina Psiquiátrica y Ciencias Bioquímicas. Fue Director del Instituto de Criminología de la Penitenciaría Nacional de Buenos Aires creado por José Ingenieros a inicios del siglo XX. Diseñó el Protocolo de Historia Clínica Criminológica para el estudio de la personalidad del delincuente.
} 
venimos arrastrando desde la colonia frente al que debemos dar respuesta definitiva, respuesta que solo nosotros podemos dar sobre las características reales que reposan en la psique de cada una de las razas que integran nuestra nación. Así como nos preguntamos sobre la delincuencia y sobre la patología mental, nos ocupa también la etiología en la raza...y por supuesto, a través de su develamiento ahondar en el ser psíquico de nuestra nación.

Para conducir a buen recaudo este objetivo, reorganiza la "Historia de Clínica Criminológica" en torno a esta preocupación (declaración). Propone reproducir ciertos aspectos de la Historia Clínica chilena y argentina, pero modificar y agregar otros. En la Historia Clínica Criminológica que propone, Endara recoge de estos dos modelos: a) "los principales datos que permitan identificar al sujeto: fotografias de frente y de perfil, datos generales e identificación dactiloscópica (...)", b) "Historia Social del delincuente: constitución del hogar paterno y antecedentes individuales (...)" y tan solo agrega "párrafos relativos a antecedentes policiales y judiciales de los miembros de la familia, y a la situación económica familiar en el momento de cometer el delito." (p. 140).

"Los formularios argentino y chileno contienen los datos esenciales, sobre todo antropométricos, para la finalidad identificadora; no así en cuanto al detalle relativo a la exploración constitucional." Por ello, la modificación y elaboración principal, es decir su propuesta para realizar investigación criminológica, gira en torno al examen antropológico que tiene una finalidad criminológica ("Acumular el mayor número de datos que garanticen una base sólida a la identificación") y otra clínico constitucional ("reunir el mayor número de elementos que nos permiten percibir las particularidades de la organización constitucional de los diferentes grupos étnicos) y así "Suministrar un apreciable aporte al diagnóstico y pronóstico psiquiátrico". Para cumplir estas dos finalidades, Endara considera que no hay mejor pauta de "exploración antropológica" que la de Kretschmer, que a pesar de ser discutida por otras escuelas, "con deficiencias y todo, nos parece que su sistemática ordenación supera en conjunto a las técnicas americanas, francesa, italianas, etc., más en boga. [Y] Aunque sólo se refiere a una cuestión de técnica, debemos recordar (...) lo indispensable que resulta en el curso de la investigación antropológica el uso de la Tabla Somatométrica elaborado por el doctor Castellanos y que es una reforma a la cuadrícula de Pende $^{32 . "(p . ~ 140-141) . ~ L a s ~ n e g r i l l a s ~ s o n ~ m i ́ a s . ~}$

\footnotetext{
${ }^{32}$ Fundador del Instituto de Biotipología individual y Ortogénesis en Italia, y uno de los precursores de la endocrinología criminal moderna que sostenía que la formación delictiva puede ser originada en una relación causal de orden orgánico. Este personaje es también clave en el desarrollo de la eugenesia en Italia y Argentina. En el segundo país, según Vallejo y Miranda (2005), la eugenesia, logró propagarse allí gracias al apoyo que recibió de las elites dirigentes (liberales y nacionalistas conservadores) que, dejando de lado sus diferencias partidarias, vieron en la eugenesia un punto de encuentro para consolidar su status a través de una "hegemonía política construida con el esfuerzo científico de teorías biológicas" que frente al "peligro de la otredad" (inmigrantes e indígenas) "operó como poderoso catalizador de intereses aunados en pos de la llamada 'defensa social', que ubicó a aquellos dentro de las omnicomprensivas categorías de enfermos o criminales.” (p. 146). De allí que su desarrollo institucional fuese múltiple. Encontró cabida en la planificación urbana y la educación que conjugaron una profilaxis social y Antropométrica Galtoniana - Vucetichiana con una educación eugenésica para "adaptables" al sistema y "puericultura antes de la procreación” (p. 151). Encontró espacio en
} 
Si la investigación antropológica (endócrina, criminológica y clínico constitucional) es la novedad en la propuesta de Endara, cabe mencionar que la antropometría, ese elemento para la identificación criminológica en los formularios de Chile y Argentina del que no se desprende Endara, es, según Gustavo Vallejo y Marisa Miranda (2005), una herramienta clave para la conformación de un saber sobre el individuo desde la tercera década del siglo $\mathrm{XX}$ y que comprende un saber sobre el pasado, el presente y el futuro biológico, psicológico, y social del individuo así como de su responsable o irresponsable grado de mestizaje (170).

La aplicación de la antropometría en Ecuador, señala Eduardo Kingman (2008), coincide con el criterio de que el comportamiento violento y antisocial está ligado a una determinada estructura psíquica y física distinta a la normal y que dicha estructura se manifiesta en los caracteres fisionómicos (312). Dicho criterio, en el caso de las fichas de medicina antropométrica en Argentina (país en el que Endara se formó), según Vallejo y Miranda (2005), tienen un andamiaje epistemológico e institucional compuesto por elementos conceptuales de la Eugenesia, la Biotipología y la Medicina social y que conformaban, en el caso de este país, una "biología política" para la legitimación sociopolítica de las diferencias clasificatorias raciales establecidas por Galton y que buscaron instaurar una base científica para la determinación del lugar que cada quien debe ocupar en una sociedad a la que Galton "concebía como una máquina bien ajustada, controlada y calibrada por las clases altas. En su operativizada interpretación de la 'Teoría de la evolución', las diferencias entre razas y clases sociales quedaban equiparadas a las que presentaban las especies animales.” (Vallejo y Miranda, 2005, p. 149).

Las mediciones antropométricas fueron el sustento de los patrones de normalidad sobre los que Galton estableció las diferencias raciales y de clase. De allí su interés por estudiar las huellas dactilares de simios y humanos. Vucetich, el antropólogo y policía argentino de origen croata se interesó mucho en este aspecto del trabajo de Galton e hizo de éste un sistema eficaz de identificación de personas por su huellas dactilares, elaboró una "ciencia de la identificación [que] hizo de un inicial mecanismo de detección de criminales a través de las huellas dejadas en el cuerpo del delito, un fenomenal dispositivo que colocó a toda la población bajo la atenta mirada del poder. De ella se sirvieron las posteriores leyes

la Universidad, en la policía, en la investigación sobre "Antropología Infantil”, en los programas contra el alcoholismo, en el Museo Social, en las políticas migratorias y anti migratorias, en la elaboración de leyes de higiene sexual prematrimonial, etc. En ese contexto surgieron las interacciones entre Argentina y el fascismo italiano, principalmente a través de Nicolas Pende, un personaje que adquirió un lugar importante en la jerarquía del régimen italiano y cuyos conocimientos serían requeridos por la medicina Argentina. Para Vallejo y Miranda, el anudamiento del liberalismo al conservadurismo nacionalista solidificado en gran medida por la Iglesia católica, halla un vínculo en el relativismo que la biotipología pendeana otorga al "fundamento darwiniano de la eugenesia, que era precisamente motivo de repulsión en quienes aún sostenían el creacionismo" (p. 160) sin descartar las bases biológicas para explicar el orden jerárquico social de raza y clase en el país. "La biotipología pendeana era una orientación 'médico filosófica' tendiente a dilucidar y controlar todos los secretos que encerraba el cuerpo y el espíritu de los hombres. A través suyo cabía esperar la detección del peligroso universo de la otredad que podía esconderse adoptando formas diversas." (Vallejo y Miranda, 2005, p. 161) 
electorales, de admisión de funcionarios públicos y de creación de registros de inmigrantes, mendigos, vagabundos y prostitutas." (Vallejo y Miranda, 2005, p. 150).

La antropometría también fue utilizada como criterio de selección de personal en el ámbito empresarial en Quito de los años 20 y algo similar habría sucedido en Colombia tras la introducción del pensamiento criminológico positivista de manos "del abogado y líder político populista Eliécer Gaitán, quien estudió en Italia y fue discípulo de Enrico Ferri, uno de los seguidores de Cesare Lombroso" (Kingman, 2005, p. 312).

Ahora bien, según sugieren Vallejo y Miranda (2005), la eugenesia en la Argentina (una ciencia preocupada por las características biológicas de los individuos para generar un conocimiento exacto sobre las consecuencias del mestizaje y las formas adecuadas de tutelarlo desde el Estado y la ciencia para producir a futuro una ciudadanía ideal, una ciencia preocupada por dilucidar si la etiología de la degeneración recae en la herencia, como postula el darwinismo-galtoniano, o si el medio ambiente influye como plantea Lamark, una ciencia preocupada por clasificar y ubicar al individuo en la escala evolutiva para saber cómo mejorar la raza a través de exclusiones y unir un conocimiento antropológico con una moral cristiana a través de los datos obtenidos de la clasificación y jerarquización racial y de clase del individuo) se vincula a la biotipología (una orientación "médico filosófica" que buscaba develar y controlar el cuerpo y el espíritu). La "biotipología se convertía así en el principio de la tarea eugénica: solo conociendo escrupulosamente a la estructura íntima del 'cuerpo y del alma' del individuo y clasificándolo, para ubicarlo dentro de la escala evolutiva de la especie podía comenzar la tarea de mejora de la raza." (Vallejo y Miranda, 2005, p. 165).

Biotipología y Eugenesia, como había mencionado, se vincularon además a la Medicina Social "área que involucraba a su vez a la medicina del trabajo" cuyos propósitos se situaban en 'el afán de atenuar las 'regresiones atávicas' ocasionadas por el trajín de la vida moderna, para que sus efectos no alteren a aquellos que garantizaban la conservación del 'potencial hereditario' y transmisión de las mejoras adquiridas a la descendencia." (Vallejo y Miranda, 2005. P. 169).

En el caso de Ecuador las mediciones antropométricas fueron usadas tempranamente en la fabricación de la figura del delincuente y posteriormente aplicadas en los años treinta a los obreros con el fin de generar un sistema clasificatorio que establezca categorías al interior del mundo del trabajo, permita el manejo del cuerpo, de los individuos y del conjunto del "cuerpo social" (Kingman, 2008). Como parte de las preocupaciones psiquiátricas en los Archivos de Criminología, aunque ya no solo con base antropométrica, sino sobre todo estadística, encontramos un sistema de clasificación somato psíquico posado en la realidad que Cruz Cueva describe al estudiar al Empleado Público (ver Cap. 1). La antropometría y la estadística se revisten de autoridad para imponer verdades y fabricar realidades imaginadas en base a un 
sistema de clasificación psicosomático de los trabajadores de las fábricas que incluía su catalogación a través de variantes como el peso, la talla, perímetro de tórax, ancho de los hombros, contorno de caderas, contorno craneal, diámetro transversal del cráneo, índice cefálico. Estas fichas fueron cruzadas con otras variables como la dieta alimentaria, el consumo de alcohol, el tabaquismo, la condición familiar. En algunos de los informes finales se acompañaban fotografías de cuerpo entero sobre tipos humanos y tipos de enfermedades. Se trataba de enfermedades sociales tales como la tuberculosis o la sífilis cuyo control pasaba por el control social del cuerpo. Los miembros de las ligas antituberculosas realizaban visitas domiciliarias e impartían nociones de higiene y de educación moral. (Kingman, 2008, p. 313).

Encuentro aquí, para el caso ecuatoriano, una relación entre la antropometría, la criminología y la psiquiatría como práctica rutinaria con antecedentes en la eugenesia, la higiene y profilaxis social en pos del establecimiento de un sistema clasificatorio somato psíquico que produzca un saber sobre el individuo y la sociedad ecuatoriana. Un saber, que según Endara, debe componerse de antropometría, antropología constitucional e investigación psicológica.

Para la exploración psicológica, Endara propone que también se aplique el esquema temperamental de Kretschmer a razón de que "tiene la enorme ventaja de adoptar el criterio genético evolutivo al estudio de dichos fenómenos [psicológicos] y suministra los datos indispensables para el estudio del delincuente." A los datos temperamentales que permite obtener la "Historia Social" vinculados a la "situación familiar y económica" que dicen "poco en cuento a la estructura compleja de los fenómenos elementales y superiores del psiquismo" se le debe sumar por un lado el "modelo de Kretschmer, que se distingue por el detalle, no olvida ninguno de los aspectos del comportamiento individual y como estos se encuentran perfectamente sistematizados y correlacionados, acaban por facilitar un perfil bastante preciso de la personalidad que se estudia." Por otro lado a la "Historia Constitucional" se añade el "examen de la inteligencia (Binet - Stanford, etc.), obtención de la evidencia delictiva, estudio de la debilidad mental, prueba de la 'penalización del delito' (Foster), etc., etc.” (p. 141).

Además, para la exploración psicológica, Endara introduce en Ecuador y en América Latina uno test que pasará a ser uno de los de mayor utilización en su obra, en sus investigaciones, en sus divulgaciones y su práctica: el test ${ }^{33}$ de Rorschach (Paladines, 2011). "Teniendo en cuenta las especiales dificultades con que se tropieza en el curso del examen de

\footnotetext{
33 'La palabra test (del latín 'testimonium') ha sido adoptada en psicología para designar a aquellas herramientas utilizadas para obtener una serie de datos específicos acerca de algún aspecto psíquico (rasgos de carácter, identificación de problemas personales, mecanismos de defensa, aptitudes, habilidades, etc.) de las personas a quienes se les aplica. El desarrollo de los test en el siglo XIX, dio origen al llamado 'movimiento psicométrico' cuyo pionero fue Francis Galton.” (Paladines, 2011, p. 14). El inglés Galton, primo de Charles Darwin, además, es el precursor de los principios de la eugenesia y de haberla convertido en política pública, "bajo la forma de tecnologías sociales y de instituciones del Estado, en el contexto de una exigencia de control creciente y de una medicalización de los problemas sociales y de la aparición de grandes deficiencias sanitarias en las grandes ciudades." (Palma, 2005, p. 116)
} 
delincuentes, y después de realizar numerosos ensayos, creemos que pocas técnicas de exploración psicológica pueden ser de tanta utilidad como el psicodiagnóstico de Rorschach. No hay que olvidar que tanto encausados como penados, son represivos habituales, que muchos de ellos son analfabetos, y la casi totalidad absolutamente incultos. (p. 141). Así caracteriza el Dr. Endara a la población carcelaria en 1937, como vimos no dista mucho de la población en el manicomio respecto de su situación social.

Finalmente, respecto a la Anamnesis Criminológica, al conjunto de datos que resulta de la historia clínica para el diagnóstico clínico, y que contempla "estudio del delito, reincidencia, índice de peligrosidad, clasificación, informe penitenciario e informe de reeducabilidad (...)", Endara recurre por completo y sin modificación alguna a la Historia Clínica del Profesor Loudet, cuyo modelo contempla:

a) "El estudio científico del delincuente mediante el método experimental (antropológico-clínico) debe objetivarse en una 'historia clínica criminológica'."

b) "La historia Clínica Criminológica es una investigación cronológica de los factores endógenos y exógenos que llevan al sujeto al delito, considerado este último como un fenómeno biológicosocial."

c) "Las etapas de dichas historias, deben ser en sus grandes líneas la de una Historia de Clínica Médica, en el sentido de integrar una 'anamnesis' antropológica y social; un 'estado actual', la personalidad fisio-psíquica del delincuente y su sintomatología antijurídica: el delito; y la evolución ulterior del sujeto bajo la acción del tratamiento penitenciario."

d) "El elevamiento de dicha historia, en sus dos primeras etapas, deben efectuarla los peritos médico-legistas y ser previa al juzgamiento criminal. Después de la sentencia, la historia debe completarse en los establecimientos de reforma, para la mejor individualización del tratamiento."

e) "Todos los establecimientos penales deben adoptar el mismo modelo de Historia Criminológica, a los efectos de organizar una estadística científica y uniforme de la criminalidad." (p. 142). Negrillas son mías.

La Historia Clínica Criminológica que propone Endara es extensa, implica un esfuerzo y dedicación con cada sujeto. Aunque no es probable que se haya empleado en toda su extensión, sí es parte del campo de visibilidad psiquiátrico con el que se va a trabajar las próximas tres décadas.

Está compuesto de catorce partes: 1) Datos generales y antropométricos (huellas dactilares y fotografías del rostro en perfil y de frente), 2) Antecedentes familiares (constitución del hogar), 3) Antecedentes individuales (historia del delincuente: actuación en el medio escolar, militar, familiar, laboral, político-social, vida carcelaria anterior; situación económica del grupo familiar al cometerse el delito: situación laboral de la familia, presupuesto del hogar), 4) Examen Antropológico (talla, cráneo, tórax y abdomen, contornos y circunferencias, dinamometría, miembros, valores), al examen antropológico se suma los 5) Índices y relaciones (tipo corporal: Sigaud y Krestchmer), 6) Características Morfológicas (cara y cráneo, estructura corporal, superficie corporal, glándulas y vísceras, 
cicatrices y tatuajes), 7) Examen Psicológico (datos clínicos y constitucionales: Herencia, curva vital, esquema general de los temperamentos, vida instintiva, estructura compleja del carácter y actitud frente a la vida, modos de comportamiento sociológico), 8) Examen fisiológico y Médico (antecedentes hereditarios y familiares, estado actual), 9) Examen físico (aparato digestivo, respiratorio, circulatorio, urinario, temperamentos, órganos de los sentidos, endócrino, desarrollo sexual), 10) Asistencia médica (durante la reclusión), 11) Examen psiquiátrico (resumen de la Historia Constitucional), 12) Evolución de la enfermedad mental y tratamiento, 13) Anamnesis Criminológica, 14) El delito (versión del testimonio, versión del recluso, modalidades del Delito, Carácter de la Reincidencia, Índice de peligrosidad, clasificación, tratamiento penitenciario).

Se puede notar de nuevo que la práctica de la institución psiquiátrica aquí sobre pasa los muros del hospital San Lázaro y se ocupa cada vez de segmentos más grandes de la población. El espacio carcelario permite generar un saber más cabal sobre el individuo y la sociedad ecuatoriana. En adelante las investigaciones que se publican en la revista contemplarán la raza como variable central en el campo epistemológico y conceptual psiquiátrico. Un campo que incluso sobre pasa la objetivación del crimen y se posará en la comprensión de la relación entre psique y mestizaje en el Ecuador (o al menos en su sierra), a través de un saber que conjuga a la vez saber jurídico, endócrino, antropológico-clínico, estadístico, antropométrico, biológico-social, psíquico, proyectivo (psicoanalítico), morfológico, sociológico, preventivo, clínico-constitucional.

Desde 1943 la revista, deja de publicarse durante una década. Hasta entonces había sido publicada con el apoyo del Ministerio de Gobierno y Justicia, luego de la Universidad Central del Ecuador (UCE). A partir de 1953 es publicada por la Casa de la Cultura Ecuatoriana en Quito ${ }^{34}$ (CCE). Sus propios editores han nombrado este periodo como "segunda etapa". En esta etapa, con un campo de visibilidad que amalgama análisis de la personalidad (proyectivo), clínico-constitucional, bio-tipológico, biológico-social, se retoma la discusión sobre la raza, y a través de ella de la psique del indígena y la psique del pueblo ecuatoriano en general. Pero la discusión, como veremos, se retoma en el marco de la CCE, una institución que ha construido una narrativa sobre la nación a la que pretende aglutinar mediante la cultura. Aquí se generan unas dinámicas e imbricaciones entre la exaltación del mestizaje y un indigenismo psiquiátrico que confluyen en un horizonte de expectativas eugenésico, médico-higiénico-social para el futuro presente de la nación y una (re)lectura de su(s) pasado(s) y presente(s).

\subsection{Kretschmer, la biología y la historia: Teoría constitucional y el uso nativo del pasado}

\footnotetext{
${ }^{34}$ La revista en su tercera etapa "(...) ha llegado al siglo XXI, editada por la Facultad de Jurisprudencia, Ciencias Políticas y Sociales de la Universidad Central.” (Landázuri, 2008, p. 414). La revista entró en el 2018 en un nuevo periodo de inactividad.
} 
Podría decir que "Notas bibliográficas" y "Revista de Revistas", junto a la sección "Informaciones" y las publicaciones internacionales, son de las secciones estables de la revista. Hasta finales de los años 50's hay secciones que aparecen y desaparecen. Incluso la editorial no es una constante y quizá la más notable, en términos de intervención política, es la que se escribe en rechazo a la invasión de la Universidad Central del Ecuador en marzo de 1966 por parte de la dictadura militar.

Reseñar trabajos científicos publicados en revistas y comentar libros que sobre pasan los especializados en psiquiatría implica un gran esfuerzo. Los médicos y psiquiatras agotan la bibliografía en distintos idiomas, francés e inglés principalmente, y la traducen para presentar un estado sobre discusiones alrededor de la literatura, filosofía, historia, neuropsiquiatría, etc.

Estas secciones son una muestra de sus referencias teóricas, de su capacidad de acceso a estas publicaciones, de su eclecticismo, y en lo que respecta a las publicaciones internacionales, reflejan el círculo profesional con el que se vinculan, sobre todo Julio Endara quien, según Landázuri (2008), se codea con personajes que son considerados eminencias en su país. Así se constata al encontrar en las publicaciones nombres tales como Honorio Delgado (Perú), Juan Dalma (Argentina), Emilio Fournié (Uruguay), Vallejo-Nágera (España) y El mismo Ernst Kretschmer (Alemania) con quien Endara compartió personalmente en el Congreso Internacional de Neuro-Psiquiatría y NeuroCirugía en Santiago de Chile en 1952.

Endara recuerda este encuentro en el número de Abril-Junio de 1954 de los Archivos de Criminología. Allí señala la importancia de la Teoría Constitucional para la Psiquiatría y para la medicina en general. Además, recuerda su esfuerzo por difundir esta teoría desde 1927 en el Ecuador, y lo elemental que ha sido Kretschmer para la investigación en Criminología. "Desde 1936 fué incorporado su esquema Psicobiológico a la Ficha Criminológica del Instituto de Criminología, y desde entonces no nos hemos apartado de su aplicación"-dice Endara-.

Reconocimiento que es compartido por Agustín Cueva Tamariz en el mismo número de la revista. Para Cueva, la obra del científico alemán sobre pasa a la medicina y toca al "saber humano (...) Pero su profundidad investigadora y claridad conceptual llegan a la cúspide cuando correlaciona el cuadro psíquico con la forma corporal de la persona estudiada sea o no acreedora de la calificación de enfermo. (...) ha abierto insospechadas vías de investigación en diversos sectores del saber humano, por lo que no pueden prescindir de él el médico, el psicólogo, el sociólogo, el pedagogo, el sacerdote y toda persona culta que quiera estar a la altura del contenido intelectual de su tiempo.” (p. 245). La teoría constitucional para Cueva Tamariz equivale a lo actual, a lo presente, a lo moderno. Y sus posibilidades le resultan ilimitadas. 
Para Cueva Tamariz, la teoría de Kretschmer permitía no solo estudiar la anormalidad psíquica, permitía ocuparse de algo que va más allá de los límites de la cárcel y del hospital psiquiátrico, permite ocuparse también de la normalidad ${ }^{35}$ de los sujetos estudiados. Además, permite comprender la "normalidad del superdotado", pues permitía comprender las particularidades psíquicas de los "Hombres Geniales". La Teoría Constitucional lleva a Cueva Tamariz a considerar la pertinencia de interpretar la obra intelectual y artística, y sus nexos con la personalidad, de personajes relevantes de habla hispana a partir del estudio "somatopsíquico" y "psicobiológico" de su genio y obra. Es así que cuando Cueva Tamariz comenta la cita que el Dr. Oliver Brachfeld, (director del Instituto de Psicosíntesis y Relaciones Humanas de la Universidad de Los Andes, Merida-Venezuela), ha hecho sobre un estudio que Cueva realizó sobre la personalidad de Don Simón Rodríguez, el maestro del "Libertador de Cinco Naciones", Cueva Tamariz (1954) se ve en la necesidad de hacer una "ligera exposición de los motivo que [tuvo] para el intento, acaso no realizado, de penetrar hasta el fondo del espíritu de esa figura genial para reconocerlo en su escueta realidad humana, desentrañando del subsuelo de su biografía las características psicológicas de su compleja personalidad (...)" (248).

Para Cueva Tamariz se trata de encontrar el pasado a través de lo que denomina con mayúsculas "REVISIÓN PSICOBIOLÓGICA DE LAS FIGURAS DEL PASADO". Una postura que va más allá de la escritura de biografías que de por sí son "las más perfectas" cuando son interpretadas por "los biólogos -médicos y psiquiatras- que a la vez sean hombres de letras (...)", pues "El médico, cuando hace biografía, tiene el dón de ver en el fondo mismo de las almas: para él no hay secretos, porque sus ojos avezados penetran en las reconditeces del espíritu y captan la más leve irisación sentimental. El médico está mejor capacitado para interpretar a sus semejantes, porque juzgar es comprender. Y la conducta humana de los hombres en el devenir de la historia, es una línea irregular, de acuerdo con el temperamento." (248) El devenir de la historia entonces, está sujeto al temperamento y la biología de las personas.

Cueva Tamariz, considera que "Solo los médicos, y especialmente los psiquiatras" pueden entender el pasado con esa precisión "a la luz de las nuevas disciplinas de la ciencia".

\footnotetext{
${ }^{35}$ Cabe destacar que ocuparse de la normalidad es también de interés en la Argentina. Las fichas de medición antropométricas, tras los aportes de Víctor Mercante, miembro de la Universidad Nacional de La Plata, se convirtieron en instrumento de categorización de individuos provenientes de distintos sectores de la población "con el claro objetivo de servir de documentos, legitimados científicamente, para operativizar mecanismos de clasificación y exclusión instrumentados por organismos estatales". Pero esta categorización, después de realizar un estudio sobre el presente y el pasado biológico (eugenésico, biotipológico, social) de un individuo sobre el que se concluyera su normalidad, introducía esa normalidad como elemento de evaluación presente y futura de esa misma normalidad. Se trataba de supervisar en el tiempo aquella normalidad, evaluar y clasificar su rectitud o sus desvíos. "La clasificación del 'método de Vucetich' devenía así, mediatizada por los aportes de Mercante, en la conformación de parámetros biotipológico donde el dispositivo concebido inicialmente para identificar reincidentes, apartados de la normalidad, se expandía ahora de modo inusitado sobre la propia esfera de lo normal, para volverla objeto de escrupulosas indagaciones que buscaban permanentemente poner a prueba esa condición." (Vallejo y Miranda, 2005, p. 170).
} 
Especialmente de tres disciplinas "la psicopatología, para establecer las relaciones que existen entre lo normal y lo patológico; la endocrinología para determinar los factores temperamentales y caracterológicos; el psicoanálisis, en último término, para sondear esas capas profundas de la subconsciencia y establecer el origen de los complejos reprimidos, de los conflictos represados que germinan silenciosamente en espera de su madurez para exteriorizarse." (249). Encontramos aquí una apuesta teórica con la que este médico, psiquiatra y hombre de letras mira al pasado, ya no se trata solo de la patología, del crimen, de la normalidad o del presente, sino de la comprensión psiquiátrica y médica de la historia que a su vez implica el develamiento del porvenir.

Endocrinología, psicopatología y psicoanálisis son los componentes teóricos para la revisión de pasado. No solo uno, los tres, pues para Cueva Tamariz, son psique y biología los que determinan la historia; lo normal, lo anormal y superdotado son efectos de la relación entre psique y biología. Si se toma solo al psicoanálisis, dice Cueva Tamariz, se "profundiza en el yo, desconectándolo de la realidad objetiva de los procesos biológicos" descuidando la "explicación de la psicogénesis de sus perturbaciones anímicas [desatendiendo] la realidad objetiva de sus fenómenos, que escudriña la psiquiatría para fijar los componentes del ser y las reacciones activo-afectivas de modo de ser (...)" (251). Por ello es que la psicopatología y la endocrinología deben sumarse a la "valoración somática y psíquica" de personajes de pasado, pues - dice Cueva Tamariz- "la historia la hacen los caracteres y los caracteres son el núcleo del objeto de la psiquiatría. Y debido a la investigación de esos estados endocrinológicos, se ha creado hoy la posibilidad de penetrar en la doctrina de la constitución humana y del temperamento, es decir, de la variación de la individualidad fisiológica y de la personalidad, o entrar, con valor y decisión, en el problema de los biotipos humanos." (249). (Las negrillas son mías).

Ello permite, según Cueva Tamariz, diferenciar a esta postura de la tradición lombrosiana que estableció una relación entre genio y degeneración.

\footnotetext{
"Ya nadie -ni en los ambientes científico más retrasados- insiste en propagar la tradición lombrosiana de la identidad del genio y la degeneración. Esta concepción tuvo su origen en una de las obras que abrieron nuevos horizontes a la Antropología Criminal (...) Desde entonces, se generalizó, cada vez más la creencia de que no podía existir genio, sin neurosis epiléptica. (...) Efectivamente, respecto del genio, Lombroso sostuvo la relación entre el genio y la locura; relación de origen y relación de naturaleza. Ese fue el ambiente -diríasedoctrinario dentro del cual concretó algunas otras afirmaciones. Pero todas ellas han sido ya sometidas a una severa crítica, hecha ampliamente con eficacia por todos los psiquiatras modernos." (Cueva Tamariz, 1954, p.250). Las negrillas son mías.
}

Cueva Tamariz, al igual que Endara con la Historia Clínica Criminológica, marca una distancia conceptual, marcando a su vez una distancia temporal con la enunciación "científicos retrasado" y "los psiquiatras modernos", los nuevos que se encuentran en una etapa actual del avance científico, y que ya no recurren a la tesis lombrosiana de la 
Antropología Criminal que sostiene la existencia de una correlación "natural" entre el Genio y la Locura (degeneración). Desde la endocrinología se formula la categoría del superdotado para referirse a la correlación entre normalidad y genio. La mirada de Cueva Tamariz opera desde otro campo de visibilidad que establece relaciones distintas entre cuerpo, psique, patología, normalidad, organismo y genialidad. $\mathrm{Y}$ ese marco epistemológico produce otra narrativa sobre el pasado.

Encontramos aquí que el uso de la teoría de Kretschmer constituye una concepción nativa de tiempo que por un lado articula la diferenciación con un pasado teórico "doctrinario" y un presente científico. Usar a Kretschmer es lo moderno. Lombroso forma parte de un pasado de la Antropología Criminal que establece una relación intrínseca entre genio y neurosis epiléptica que es insostenible frente a la teoría constitucional moderna, nueva, actual. Defender esa postura ubicaría a sus partidarios en un estadio más lejano aún que un "retraso" teórico.

La inteligibilidad del objeto de saber psiquiátrico, que para Cueva Tamariz es el "carácter", que a su vez sería, según este psiquiatra, eje de construcción del objeto histórico, es una concepción nativa del tiempo que define la identidad moderna de los psiquiatras, en la medida que sustenta su postura a través de una legitimación teórica que proviene de su diferenciación temporal, con una división entre un pasado lombrosiano y un presente Kretschmeriano. El presente teórico está compuesto por la psicobiología en detrimento de un pasado teórico (y también de un presente) que no contemple el componente psicopatológico, endócrino y psíquico. Entonces, la identidad moderna de los médicos, y principalmente de los psiquiatras, se compone por la inteligibilidad psicobiológica de los objetos de saber y por la ubicación de ese objeto de conocimiento en el tiempo.

A la vez que Cueva Tamariz ubica un pasado en términos de "retraso" o "modernidad" teórica para construir la identidad moderna del psiquiatra, también realiza otra división entre pasado y presente, ya no solo entre lejanía y proximidad teórica, sino en términos de evocación del pasado emblemático y ejemplar para el presente a través de la figura de Don Simón Rodríguez, el maestro de Simón Bolívar y Andrés Bello, de quien dice:

'ese hombre de curiosa fisonomía y de extravagantes y curiosas ideas', que decía Larrazabal, y que hice, brevemente, en un capítulo de mi ensayo. Decía yo que en virtud de la hipersecreción de la hormona de crecimiento del lóbulo anterior de la hipófisis, creció en proporciones excesivas, denunciándose en él los rasgos acromegaloides de un gigantismo endocrino, correlativo a sus reacciones temperamentales características, tales como la violencia, la sexualidad exagerada, el desarrollo intelectual y a aquella forma de reacción llamada cataplexia, o sea la inhibición pasajera del tonus de la actividad, llegando hasta la picnolepsia, es decir, breve interrupción de la motilidad voluntaria de la conciencia, llegando, por inhibición vegatónica, en la mayoría de las reacciones emotivas, hasta el descontrol de la conciencia y de la omnubilación. Rasgos tan frecuentemente observados en Don Simón Rodríguez. (Cueva Tamariz, 1954, p. 248) 
La evocación del pasado en Cueva Tamariz enviste sus imágenes con la psicobiología. La apuesta por el sentido político de la historia de Cueva Tamariz es por la constitución de los hechos históricos desde la psicobiología.

Para la construcción de la identidad moderna, encontramos en el argumento de Cueva Tamariz, una concatenación entre estructura de saber y estructura de tiempo: una especialización y una espacialización. Por un lado la definición del perfil profesional moderno y las reglas de inteligibilidad de objetos de saber psiquiátrico y por otro la constitución psicobiológica del pasado emblemático y ejemplar a través de esos objetos de conocimiento psiquiátrico.

A través de la Teoría de la Constitución de Kretschmer, Cueva Tamariz hace una irrupción en el dominio político del pasado para disputar ese dominio a otras disciplinas. Propone para ello un régimen de historicidad basado en una concepción nativa del pasado que poseen solo los médicos y psiquiatras. Su concepción nativa propone la construcción del objeto histórico en base a la "verdad biológica" que se encuentra en el cuerpo somatopsíquico y psicobiológico, "porque la verdad biológica, como decía Gregorio Marañon, es, en efecto, mucho más difícil de ser deformada que la verdad histórica" (Cueva Tamariz, 1954, p. 248). Esta producción nativa de la historia busca la verdad histórica en la verdad biológica. Disputa la verdad sobre el pasado a través de la administración psicobiología de la significación sobre el pasado y el presente. Para Cueva Tamariz, se trata, de encontrar la verdad psicobiología del pasado y del presente y entender desde allí la historia.

El relato médico-psiquiátrico toma el cuerpo psicobilógico como elemento central para la producción de historia, para definir el perfil (identidad) de quienes pueden producir esa historia, y para la inteligibilidad de los objetos de saber con los que produce el sentido histórico-psicobiológico de la sociedad a la que nombra desde ese sentido. En el caso de las figuras emblemáticas del pasado, el cuerpo psicobiológico actúa como la categoría con la que se puede escribir la historia de grandes personajes que, según Cueva Tamariz, han "abierto nuevas épocas" y de lo que esos personajes significaron para esas épocas y para el presente. Para Cueva Tamariz, lo que debería destacar en el recuerdo de las naciones es la psicobiología de unos personajes del pasado. Se trata, para este psiquiatra, de rememorar y constituir la historia a través de la biología, pues esta es una verdad más precisa, una verdad que a diferencia de la "verdad histórica", no se "deforma".

Así el saber psicobiológico y antropológico constitucional del individuo pasa a ser una concepción nativa sobre el tiempo histórico que apuesta por la producción de historia y el establecimiento de un régimen de lo recordable y de historicidad psiquiátrico, y a su vez se conforma como un horizonte de expectativas y un campo de visibilidad psiquiátrico (psicobilógico, antropométrico, antropológico constitucional) para la producción de objetos 
de saber psiquiátrico, la definición intrínseca de la identidad moderna, y como veremos, para la imaginación de la nación. 
CAPÍTULO 5 


\section{5.- La eugenesia en el campo de visibilidad psiquiátrico en el Ecuador}

En las siguientes páginas voy en busca de una regularidad: de un mecanismo discursivo psiquiátrico como pieza de construcción del poder político, como forma de imaginación de la nación y de otrificación racializante. Para ello busco reponer un horizonte de expectativas que da lugar a un esquema de inteligibilidad que pretende hacer de la raza un objeto de saber psiquiátrico a través de la objetivación de la psique y la biología del indígena de la sierra ecuatoriana. Develar en ese esquema de visibilidad e inteligibilidad trazos geopolíticos de tiempo como régimen discursivo de representación con el que se objetiva la raza $\mathrm{y}$, de forma más silenciosa, se imagina a la nación produciendo una narrativa sobre ésta. Busco, en esta regularidad, el efecto desdoblador al que se sujeta la heterotopía étnica nacional en su encuentro con un proyecto de modernidad en el que participa la institución psiquiátrica.

\subsection{El indígena y la nación ecuatoriana, breve contexto histórico ${ }^{36}$}

Planteé, con Radcliffe y Westwood (1999), que las identidades en las naciones implica un juego que oscila entre la promoción de una nación centrada y su descentramiento puesto que los discursos nacionales generalmente se organizan en torno a una idea de nación que privilegia la construcción de una identidad específica como parte de un proyecto racial que incorpora las diferencias a través del Estado (p. 67). "Los racismos se pueden organizar en hegemonías raciales y proyectos raciales que promueven lo nacional y la nación centrada. Pero en tal intento, el carácter dinámico de los racismos produce el efecto contrario, desorganizan lo nacional mediante las fracturas que promueven, generando y derivando en su descentramiento. La hegemonía efectiva de estos racismos que promueven lo nacional termina construyendo sus propios sujetos, unos oficiales y otros de la subversión. Desemboca así en el reino de las identidades y su política. (P. 72).

\footnotetext{
${ }^{36}$ En este apartado se puede encontrar una breve contextualización respecto de la relación entre la imaginería sobre el indígena y la imaginería de la nación ecuatoriana que generó una relación de inclusión excusión del indígena en la narrativa nacional. Si bien varias de las imaginerías que aquí se citan parecen desarticuladas del objeto de estudio de esta tesis, éstas se insertan como casos que precisamente destacan el lugar que la imaginería sobre el indígena ha tenido en el proceso de modernización del país, en la construcción de la imagen del Ecuador como ser colectivo y en las disputas por la construcción del origen y los componentes de la identidad de la nación. Ello permitirá tener una idea más general sobre rupturas y continuidades de las distintas formas de usar la imagen del indio para elaborar una narrativa sobre el pasado y el presente así como tener una idea bastante puntual sobre las tenciones que producen las distintas memorias sobre el indígena en las batallas semióticas y políticas por establecer un consenso sobre el ser nacional que logre aglutinar a toda la población en torno a ese consenso.
} 
En Ecuador, el indígena ha sido uno de los protagonistas nodales (sino el más elemental) de la imaginería nacional. Pero no necesariamente ha sido un protagonista actor, enunciador, agente, sino más bien un protagonista ausente y desplazado. En el discurso blanco mestizo sobre la nación paradójicamente la enunciación del indígena (la presencia de la heterotopia de la nación) ha servido para abogar por una imaginación de una nación centrada, de una identidad específica que, como señalan las autoras, es parte de un proyecto racial que incorpora las diferencias a través del Estado. La enunciación del indígena ha sido expresión de la búsqueda de la organización de los racismos en hegemonías raciales que promueven la nación centrada a través de proyectos raciales, aun cuando ciertas enunciaciones parecieran buscar el descentramiento. La hegemonía efectiva de los racismos promotores de lo nacional centrado han generado, entre otros aspectos, unos sujetos y unos discursos oficiales que en la enunciación desplazadora y ausentificadora del indígena han hecho de éste un objeto de disputa por y para la formación de una nación centrada.

Si un acto de enunciación desplaza y ausenta en el momento en el que evoca es porque la otrificación conlleva una apropiación de la alteridad producida. Es decir, este proceso de producción de alteridades, resultado de la entronización de un grupo en el control de las instituciones estatales, además, puede apropiarse de elementos característicos de la cultura de las identidades subalternizadas a través de un acto que se confunde entre la administración estatal y la nación que pretende homogenizarlas. A este acto Segato (2007) lo denomina "acto de pernada simbólico", que es un acto de nacionalización y expropiación de los íconos de la cultura de los grupos bajo el dominio de la administración de una élite que se etniza para incluir en su heráldica los símbolos de los territorios apropiados.

En relación al "acto de pernada simbólico" Blanca Muratorio (1994) describe un proceso propio para el Ecuador en relación a esta otrificación-apropiación de la alteridad nacional. La autora plantea que en Ecuador, y en otros pises de América Latina, la iconografía del indio ha sido usada para legitimar el poder blanco-mestizo sobre una población étnicamente dividida y en búsqueda constante de una auto-identidad que se le escapa con la misma constancia. Cabe destacar que la iconografía del indio que es usada por los blanco-mestizos es de preferencia la figura arquetípica del indio aristócrata o guerrero. Los indígenas son imágenes del pasado moldeadas por silencios y discursos en la conciencia nacional de imagineros europeos, criollos y blanco-mestizos. El indio aquí es un objeto imaginado, no un sujeto histórico. Indio imaginado de distintas formas en distintos contextos y circunstancias culturales e históricas y con formas culturales diferenciadas tanto de los imagineros como de los imaginados.

Sobre la producción de imágenes de los indios Muratorio destaca tres aspectos. Por un lado las transformaciones de los distintos textos iconográficos revelan matices en los procesos de dominación y de relaciones interétnicas en periodos históricos diferentes. Por otro lado reflejan tanto trasformaciones estructurales como ambigüedades y contradicciones en los significados culturales de la interacción cotidiana y pone a su vez de relieve que lo 
hegemónico es un proceso social que debe ser continuamente construido y defendido. Por último, las representaciones del indio son parte de un principio de autoidentidad que permite señalar que Europa y E.E.U.U no fueron referentes que desplazaron por completo la identidad local cultural y étnica, por el contrario el "otro" (el indio aristócrata, exótico, bárbaro o idealizado como buen salvaje) fue incorporado como una diferencia que ayuda a construir la identidad propia de los blanco mestizos y criollos. Se trata aquí de un indio símbolo en la constitución de la identidad y en la legitimación de las relaciones de poder imperial y local extendido durante la Colonia, la Independencia y la República.

Para Pablo Ospina (1996) esta incorporación de indígena significó un esfuerzo por ennoblecer el pasado indígena e incorporarlo al patrimonio simbólico de las elites. Eso sí, lo hicieron con indígenas de ralea $\mathrm{y}$ de un pasado remoto, de esta manera $\mathrm{y}$ contradictoriamente, ocultando-desapareciendo a los indígenas vivos en el S. XIX y XX. Los indígenas pasan a convertirse en un pasado imaginado a conveniencia de las élites y su nuevo "centro de sentido". Sobre todo después de la reintroducción de la simbología del Indio que fue desplazada en 1780 y como consecuencia de la derrota de Tupac Amaru II señala Muratorio (1994) basada en Flores Galindo- la iconografía de la aristocracia incaica desaparecen del uso del poder político de la colonia. Tras la emergencia de los movimientos independentistas, este "centro de sentido" del que habla Ospina sería retomado con una renovación de sus significados que, como he mencionado, serían incorporados como elemento articulador "del discurso de identidad criolla y mestiza y de las prácticas ideológicas en los ámbitos político, étnico y culturales que servían para conformar las nuevas naciones." (Muratorio, 1994, p. 12). La renovación de este "centro de sentido", según la autora, guarda relación con la puesta en duda de la identidad hispana de los criollos desde el siglo XVII por parte de los europeos quienes aseguraban que América corrompía y degeneraba a los criollos asemejándolos cada vez más a los indios.

La respuesta frente a este eurocentrismo pone de manifiesto una ambigüedad (el rostro de Jano) que pareciera ser el denominador común de uso de la iconografía del indio. Por un lado, provocó una forma de afirmación de la identidad criolla acompañada de una "autovaloración de la Patria americana defendiendo (...) la humanidad del indígena abstracto (...) Por otra, provocó esa reacción que Paladines llama el mecanismo de olvido-represión (...) que llevó a los criollos ilustrados de la Colonia a ignorar la humanidad explotada del indígena real tratando de establecer la diferencia y la distancia con el barbarismo de las sublevaciones indígenas que se expandieron por la Sierra a lo largo del siglo XVIII; mecanismo que se repite con previsible regularidad en otros periodos históricos." (Muratorio, 1994, p. 13). Idealización y recuerdo nostálgico imperialista del indio histórico ausente y olvido (y denigración) del indio real presente. Se recuerda al Indio ideal para olvidar al Indio como sujeto histórico. Tal es la escisión, el hiato, la ambigüedad que señala Muratorio y Ospina y que forma parte de la movilidad de la iconografía del Indio con la que los imagineros imaginan la nación. 
Después de terminadas las guerras de la independencia la utopía del inca liberador y legitimador es desplazada por la influencia del modernismo y el liberalismo criollo, y es recuperada en nacionalismos frente a Europa y eventualmente en procesos internos de identidad. La ambigüedad frente al indígena (la invención de su mito y el silencio sobre su realidad) se reactualizan en distintos contextos, por diversos intereses sociales y políticos. Es así que, a inicios del siglo XIX el interés por el pensamiento ilustrado derivó en la adhesión de un grupo de criollos en Quito por la ciencia, una renovación de lo americano y un interés por el pasado que alimento el pensamiento independentista y el cuestionamiento al régimen colonial. El interés y adhesión al pensamiento científico europeo continuaron creando sitios de enunciación sobre el Indígena.

Fitzell (1994), en este sentido, escribe sobre como una ideología en la que confluyen un racismo científico en auge, la teoría evolucionista y una fascinación por lo exótico encuentra adeptos en unas clases altas terratenientes quiteñas que compartían caracteres sociales e ideológicos con viajeros europeos que realizaron una descripción de la serranía ecuatoriana del siglo XIX en base a etnografías y realismo. Este discurso derivó en el relato de un Indio abstracto en base a modelos de raza y empirismo provenientes de Europa. Si los viajeros mantenían nexos con los terratenientes de la capital, era porque esta clase en su orientación hacia Europa ató vínculos con los viajeros legitimando así su trabajo científico y su posición social en el país. El trabajo de los científicos se vio alterado por el establecimiento de hoteles a afínales del siglo XIX y por la gestión del Presidente García Moreno para el desarrollo de las ciencias positivas que permitió el establecimiento directo entre científicos extranjeros y nacionales a partir de la profesionalización de científicos en Ecuador.

Los viajeros describieron con detalle empírico escenas de la vida cotidiana a partir de usos con propósitos diversos y con diferentes puntos de vista ideológico. El autor señala tres usos. La primera imagen era la del indio encapsulado en su representación como bestia de carga. La segunda imagen correspondía a la percepción europea del exotismo, la sensualidad o el desenfreno y se concentraban en la descripción de las festividades de los Indios de la sierra. La tercera imagen expuso la percepción de la resistencia o subversión del indígena frente a la estructura social, civil y religiosa. En estas imágenes la descripción del otro y el nosotros de los viajeros correspondía a una cadena de significados dentro de un contexto europeo actualizado por el discurso del progreso. Los viajeros leían desde allí a los indígenas y no construyeron sentido por fuera de esos significados. Como concepto el progreso armó un puente entre la ciencia y lo exótico que articuló las representaciones sobre los indígenas de la serranía. Progreso

"Explica las diferencias sociales y culturales observadas por los viajeros y ofrecía una justificación científica del interés en la experiencia exótica. Los indígenas constituían un contrapunto perfecto para ambos proyectos: la centralidad del tema indígena comunicaría la experiencia del exotismo a los lectores europeos y las diferencias descritas servirían como una base de datos para abogar por la hegemonía europea del racismo científico y el 
progreso. Los Indios eran la encarnación de la falta de progreso en los relatos del siglo XIX, ya sea como sujetos activos (barbaros) o como objetos pasivos (esclavos)." (Fitzell, 1994, p. $60)$.

Vemos como desde el siglo XIX el racismo científico, la Teoría de la evolución permiten articular una imagen sobre el indígena.

Con el progreso como brújula de los viajeros el tema central de la discusión consistía en definir si los indígenas estaban o no evolucionando desde un estado de barbarie hacia uno de civilización o si por el contrario habían degenerado de un estado de civilización anterior a uno incivilizado. La medición de lo civilizado y lo bárbaro o degenerado que podía ser el indígena según los imagineros viajeros europeos variaba según el lugar que habitaba el Indio. La raza facilitó dibujar un indio genérico enmarcado en las generalizaciones de las imágenes que relataban la experiencia cotidiana que les permitían convencer a sus lectores europeos de la veracidad y cientificidad de sus afirmaciones. Es así que a los habitantes indígenas urbanos se los distinguía por su clase, ocupación y raza. A los indígenas de Quito se los reclasificó a partir de una percepción y juzgamiento en relación a las expetativas europeas de buen comportamiento de la clase obrera y no tanto en consonancia con la Naturaleza y la Cultura. Los indígenas de la ciudad no eran ni "habitantes originales" ni -animales" como lo eran los indígenas de otras regiones del país en sus descripciones, eran "buenos" o "malos trabajadores". Los "Indios del campo se los conceptuaba solo en relación con las normas supuestamente universales de Civilización y a Barbarie. Los Indios rurales seguían siendo la encarnación de una raza atrasada y bárbara que vivía en el pasado y en una estrecha relación con la naturaleza." (Fitzell, 1994, p. 65).

Y eran esas las representaciones que llevaban y con las que los europeos percibían no solo a los indios del país sino a la nación ecuatoriana, pues a través de estas imágenes racializadas y racializantes el Nosotros-civilizado-europeo del progreso justificaba su competencia para mantener el orden social y político del otro que está incapacitado para hacerlo desde su mirada externa. Partiendo de esta relación de exterioridad entre culturas y territorios Fitzell introduce la noción de nación como objeto imaginado por otros. No solo de imaginación interna, sino como objeto imaginado por otras naciones. Esta imaginación implica una abstracción de la diferencia y una exotización del Indio que no solo sería una imagen que transitaba en Europa sino que sería parte de los elementos que conforman la imaginación interna. Tanto las imágenes que circulan al interior o al exterior de la nación son parte de la delimitación identitaria del otros y el nosotros.

Al interior de la nación ecuatoriana, a finales del siglo XIX e inicios del XX, el indio, según Muratorio (1994), pasó a convertirse en el "peón semiótico" en la lucha entre dos hegemonías en un momento crítico del Ecuador como Estado-nación moderno: la liberal y la conservadora, liderada esta última por la Iglesia católica. 
Este problema sobre la legitimidad de la identidad que le es consustancial a todo proceso de conformación del Estado-nación moderno y que implica litigios entre grupos dominantes, es analizada por Blanca Muratorio (1994) en tres "teatros internacionales" en los cuales los grupos dominantes blanco-mestizo del periodo del Progresismo (1884-1895) desplegaron su ideología para legitimar su poder. Estos "teatros" fueron la Exposición Histórica Americana de Madrid de 1892, la Exposición Universal Colombina de Chicago ambas en conmemoración del Cuarto Centenario del Descubrimiento de América. El tercer escenario sería la Exposición Universal del París de 1889 en celebración del centenario de la Revolución Francesa.

Al observar la representación de la nación en estos "teatros" Muratorio encuentra un "patriotismo arqueológico" 37 como una "ideología del mestizaje homogenizante" que es fundamento de la conformación de la nación-Estado en Ecuador y que no coloca al otro (salvaje, primitivo, mítico) en oposición sino que lo incorpora en su propia autoidentificación. El "patriotismo arqueológico" trata de una tradición inventada que se apropia tanto de las glorias culturales de las civilizaciones indígenas precolombinas como de su pasado histórico para incorporarlos como un mito de origen que teje la identidad individual y colectiva. (Muratorio 1994, p. 133).

El patriotismo arqueológico exhibido en la ferias de París y Chicago contaron con contribuciones económicas, políticas y de tiempo de grandes financistas y hombres de negocios. La razón que señala Muratorio es que la hegemonía de la burguesía a finales del siglo XIX acertó un triunfo al hacer que estas ferias "crearan una visión de la realidad misma como universo de mercancías" al hacer de las ferias "universos simbólicos coherentes" que comprimían ideas dominantes y representaciones en edificios, eventos, rituales que establecieron conexiones concretas entre racismo científico, nacionalismo, evolucionismo y progreso tecnológico que se convertirían en centros de interpretación de la realidad nacional. Estas ferias, dice Muratorio (1994) organizaron "el mundo como una exhibición" (p. 118) que desplazaba y reducía a las culturas representadas en lo exótico.

En los libros e informes que la autora analiza sobre las exposiciones consta la retórica del proceso por el cual los grupos dominantes produjeron y reprodujeron sus significados culturales hegemónicos en los que reafirman el universo étnico y cultural de los blancomestizos católicos. Por ejemplo, la autora señala que en la introducción al Catálogo General de la Exposición Histórico Americana de 1893 en Madrid dedicada al Ecuador contiene un extenso relato sobre la historia oficial del país desde su pasado precolombino que abre dos imágenes del país: una sobre el origen de la nación y otra sobre el progreso. La primera coloca a Quito como origen del Ecuador como nación e incluso como origen de la civilización del Perú, la otra imagen coloca a Guayaquil como presente y futuro económico y del Progreso del país.

\footnotetext{
${ }^{37}$ Toma esta nominación de nominación de Charles Minguet.
} 
Al interior de la nación ecuatoriana, en vista de que el liberalismo carecía de una contraiconografía para oponerla a los símbolos de la iglesia católica extendidos por todo el territorio se vio sin más que recurrir a una práctica ya inventada y probada por la misma iglesia. Es así que el liberalismo emprendió una reinvención de los símbolos para una religión nacionalista secular a través de la invención de sus propios espacios sagrados. Compiten con la iglesia instalando monumentos y nuevos tiempos a través de la invención de nuevas festividades. Los partidos políticos le otorgaron valor a la publicidad como herramienta de disputa iconográfica contra la iglesia, Además, la Primera Exposición Nacional de 1892 fue promovida como marco de competencia contra la iglesia en donde los liberales ensalzaron el progreso y lo instalaron como ideología que posicionó al liberalismo secular y la trascendencia del desarrollo de la Ciencia, la Industria, el Trabajo y el Comercio.

En suma, Muratorio centra

\begin{abstract}
"su atención en el Ser blanco-mestizo como el principal interlocutor en el diálogo entre la nación-estado y la indianidad dominada. Como grupo dominante a finales del siglo XIX la burguesía de la costa usó a los indios como 'peones semióticos' (Godie 1989: 10) para sus propios intereses iconográficos y para legitimar sus propios éxitos económicos. En este proceso también comenzó a construir una imagen del Ecuador como Ser colectivo. En este sistema dominante de representación, la imagen del mestizaje emerge como 'una ficción maestra' (Geertz 1985) construida en un proceso dialéctico de exclusión e inclusión del Otro indígena. Como seudo-europeos, los criollos pretendían esconder este diálogo de dominación tornándolo en un monólogo del Ser, quien a finalmente asimilado al Otro en la familiaridad de la propia identidad, o está en vías de hacerlo. Esta se convierte así en la 'estratégica egocéntrica' más esencial de estructurar la alteridad (Mason 1990: 163). En ese proceso el Indio cotidiano es obliterado de la conciencia para ser asimilado como otro histórico, o mejor aún arqueológico-pero siempre exótico. Más aún, esta estrategia también crea la ilusión de que le Otro indígena, tal como ha sido creado por el dominador, puede ser introducido a la 'comunidad imaginada' por la puerta de los vínculos 'naturales' inventados.” (Muratorio, 1994, p. 177).
\end{abstract}

Muratorio por ello va a entender a la nación como un objeto de idealización (española y después criolla) para la producción legitimadora de la diferencia (el otro textual semióticamente construido) pero para su propia dominación semiótica a través de la incorporación de esta diferencia idealizada-producida, legitimada y dominada en pos de la construcción de la identidad propia. La otrificación es semióticamente producida en un espacio nacional idealizado, pero también como he mencionado especializado y espacializado.

Este "modelo" ambiguo de nación de los grupos dominantes blanco-mestizos, que implica un dominio semiótico de la representación del otro de la nación, se extendió durante todo el siglo $\mathrm{XX}$, solo la última década del siglo marcó un resquebrajamiento al modelo tras los exitosos levantamientos indígenas y la consolidación política de su movimiento (que incluyó una postulación de un nuevo proyecto de nación). Consolidación con un alto grado 
de representación en distintas esferas del Estado y la legitimidad política de su voz en la sociedad ecuatoriana. Andrés Guerrero concuerda con que el dominio del poder semiótico de la élite blanco mestiza encontró un punto de quiebre en la misma década y por las mismas razones. Pero agrega que este modelo de poder semiótico o el consenso iconográfico tuvo otra fisura: la caída de la práctica ventrílocua blanco-mestiza ${ }^{38}$.

Andrés Guerrero (1994-1997) al observar la pugna entre liberales y conservadores por el dominio de la iconografía del Indio, toma como punto de partida la problemática de la ciudadanización del indígena para entender la formación de la imagen política del Indio a finales del siglo XIX. Imagen que se oficializa como ideología de Estado con la instalación de la Revolución liberal y que se continua en corrientes intelectuales de izquierda durante todo el siglo XX y caduca como sentido práctico en la última década de este siglo, como he mencionado antes. El autor postula que en el momento en que el Estado elimina la figura del indio tributario en 1857, elimina también la existencia de la mayoría étnica diferente, y lo hace bajo el título homologador de ciudadano. La ciudadanía significó el cese de los derechos colectivos con especificidad étnica (p. 200). Lo que ocasionó este cese de derechos tras la instauración de la ciudadanía fue la delegación de las poblaciones a poderes privados y regionales.

Para Guerrero, es este cese y este olvido del Estado el que permite a las fuerzas políticas del liberalismo reclamar para sí las representaciones del Indio. Con ella desafían a los conservadores y a la iglesia. Es así que el discurso sobre el Indio aflora por todas las escenas del conflicto político. El Indio fue la punta de lanza contra la iglesia. Entremezcló y condenso discursos jurídicos, racialistas y políticos sobre el Indio que derivó en una administración étnica: a) administración del Indio como hecho público (1830-1857); b) en

38 Antes de definir lo que es la imagen ventrílocua tómese en cuenta la siguiente escena descrita por Muratorio sobre la imagen del indígena exótico para contrastarlo con la imaginería liberal sobre el indio oprimido que requiere ser liberado: Muratorio plantea que la discusión sobre qué exhibir llevó a los imagineros de finales del siglo XIX a acordar llevar a indígenas otavaleños y no a Jíbaros a las exposiciones internacionales. Allí las familias seleccionadas de Otavalo, ciudad de la provincia de Imbabura, tenían que simular vivir en chozas selváticas. Es decir debían simular la cotidianidad de la Amazonía ubicada en la provincia del Napo. La razón era que los propios Jíbaros a quienes se quería representar eran "salvajes" a ojos de los imagineros y no colaborarían con la limpieza de las chozas y demás aspectos de la exposición porque eran incapaces de seguir instrucciones y de solidarizarse con las cusas nacionales. En cambio los indígena otavaleños son percibidos como el modelo del indígena bien adaptado a los requerimientos de una nación moderna y capitalista. Saben comportarse, son inteligentes, trabajan, siguen instrucciones y son más aseados (p. 127). Esta discusión refleja no solo lo convencidas que estaban las élites sobre los beneficios que supuestamente tenía para el país exhibir lo exótico, sino que existía un "consenso iconográfico nacionalista republicano" (Muratorio, 1994) que desplegado para el consumo de otros estados mediante las ferias permitía la exclusión de la imagen de los indígenas a la vez que la exhibía. Ello es posible gracias a que el consenso iconográfico se sustenta en aquel movimiento realizado en la Independencia en el cual teóricamente la Independencia había convertido a los indígenas en ciudadanos absorbiéndolos en el Ser colectivo de la Nación. 
un acto de omisión antes que una política estatal, la administración de los pueblos indígenas es delegada aun ámbito privado (poderes locales y regionales). Este modelo dura hasta mediados del siglo XX. En el trasfondo de la ciudadanía los indígenas pasan de ser sujetos tributarios a ser "sujetos étnicos" del Estado Republicano. Esta es la base de la condición de posibilidad de una imagen del indígena para que el liberalismo como fuerza política esculpiera un Indio acorde a sus intereses como estrategia de poder e imponerla como envite para desafiar a inicios del siglo XX a los conservadores y la Iglesia católica. (Guerrero, 1994, p. 202). Esta imagen interna producida por los liberales dista de la producida por la élite progresista y exportada hacia el exterior porque no parte de su mítica sino de supuestos tácitos del dominio étnico, o como la denomina Guerrero, parte de una "coyuntura de remisión" que es una sedimentación de intereses personales compartidos social y culturalmente por los imagineros liberales, e instalado en la cotidianidad ecuatoriana.

La imagen que crea el liberalismo, o más precisamente retoma, es la imagen de un Indio miserable, oprimido, pasivo y ultrajado que requiere independizarse de su condición. Esta vez la imagen del indio oprimido no se emplea para deslegitimar el dominio español sino para derruir el rol opresor de la administración política de los conservadores así como el rol paternal de la Iglesia. Uno de los principales objetivos del liberalismo fue la separación de la Iglesia y el Estado así como el cese del monopolio de la vida cultural que ejercía la iglesia católica. Ambos aspectos tocaban directamente la vida del Indio a razón de que los párrocos eran los únicos encargados de la educación de los indígenas desde hace muchos siglos atrás. "Al desautorizar a la iglesia como agente civilizador y asignar la tarea al estado, se la desbancaba de una función mayor en la sociedad y, de paso, perdía la protección de los indios, una función que había sido suya desde inicios de la colonización española." (Guerrero, 1994, p. 232).

Es así que tras el ascenso del liberalismo al Estado y como ideología de Estado a partir de 1985, éste pasa a ocupar el lugar legítimo para administrar al indígena y para hablar por y en nombre de su "raza". Es en este marco, además, que el Indio es incluido dentro de la retórica de una nueva comunidad imagina que incluye la ciudadanía igualitaria y culturalmente homogénea. Homogeneidad construida desde el blanco-mestizo en términos raciales. Uno de los aportes más interesantes de Guerrero es señalar que todo esto condujo al advenimiento del Estado protector y ello configuró una forma de representación del indígena que el autor denomina como "ventriloquía política", que es una práctica blancomestiza que consistía en actuar como intermediario étnico que habla frente al Estado y la sociedad en nombre del sujeto Indio. La "ventriloquía política" es parte de esas prácticas que expresan la ambigüedad de la incorporación del indígena a la heráldica nacional y que se extendió hasta la última década del siglo XX en Ecuador.

La permanencia de tal ambigüedad es notable a mediados del siglo XX cuando, según Polo (2002), la re-armadura del espacio simbólico de la nación ecuatoriana a razón de su 
resquebrajamiento por la pérdida de la guerra y de territorio con el Perú, ubicó la imagen del indígena al servicio de la reconfiguración de la nación blanco-mestiza. Esta vez el indígena como peón semiótico de la nación permitió recomponer un racismo de las clases dominantes y del Estado perfilando una narrativa que asume al mestizo como identidad única desde la cual es posible participar y ser ciudadano. Según este autor, la fundación de la Casa de la Cultura Ecuatoriana Benjamín Carrión, fue una institución clave para la promoción de una "narrativa mestiza" gracias a que fue un lugar de confluencia de intelectuales que contribuyeron en la elaboración y difusión de la identidad mestiza. Es así que para este autor la nación, pasa a ser un espacio de configuración de los campos (intelectual, cultural) a través de la composición de un orden simbólico para el ejercicio de la dominación y el control social. Esta composición, según el autor, devino en Ecuador en una teleología de la historia nacional y en un racimo de Estado en el que participaron los intelectuales, tanto en la definición de los meta-relatos de la nación, como en la disputa de objetos configuradores del campo como parte de un proceso de modernización.

No analizaré aquí el descentramiento de la nación, las temporalidades complejas o el tiempo heterogéneo de la nación en términos de la subversión a las promociones de la nación centrada y de los distintos usos subvertores que impugnan y reinventan las imágenes homogéneas de la nación. Más bien me ocuparé de las temporalidades complejas, los usos del pasado, la heterotopia y el descentramiento de la nación a partir de la ambigüedad sobre el indígena a la que he hecho referencia en este subcapítulo. Pienso en una nueva ambigüedad, en una complejidad distinta que se abre tras la evocación del indio mítico y el indio real en un grupo de trabajos médicos y psiquiátricos que, a través de la lectura de la "realidad" y la "historia" del indígena con terminología proveniente del Psicoanálisis, la Eugenésico, la Antropología Endócrina y la biología proponen al "indio somato-psíquico" y "psicobiológico" como nueva categoría movilizadora de la imaginería blanco mestiza de la identidad de la nación ecuatoriana. La particularidad es que el "peón semiótico" esta vez actúa como un sistema de verificación de verdades psíquicas y biológicas que postulan una taxonomía diferente sobre lo normal y lo patológico en el cuerpo nacional.

\subsection{Temporalidad utópico-eugénica para la nación}

De la eugenesia, lo primero que salta a la vista es el lema del Segundo Congreso Internacional de Eugenesia en 1921 que dice "La eugenesia es la autodirección de la evolución humana". Aún más significante que este lema resulta un árbol en representación de una ciencia que unifica una variedad ramificada casi interminable de campos del saber. Luego, resalta al leer su historia y desarrollo que la eugenesia pasará a ser una apuesta epistemológica de gran alcance e interdisciplinaria en la

cual estuvo comprometida la comunidad internacional, y cuyo objetivo era el mejoramiento/progreso de la humanidad o de grupos humanos, por medio del conocimiento científico y a través de la implementación de diversas 
políticas públicas. (...) la eugenesia ocupó la atención de una enorme cantidad de integrantes de la comunidad científica 'muchos mundialmente reconocidos' incluyendo biólogos, médicos, genetistas, demógrafos, juristas, psiquiatras y otros (...) a pesar de no ser un movimiento homogéneo ha ocupado un lugar central en áreas como la salud -incluida la salud mental- y distintas política públicas como, por ejemplo, la poblacional e inmigratoria. Al mismo tiempo, toda la literatura eugenésica hace hincapié en que se trata de la ciencia más avanzada operando en la mejora de la humanidad, la expresión más acabada de la razón humana operando sobre la especie. (Palma, 2005, p. 119-120)

La eugenesia es modernidad, ciencia que expresa en la formulación de su neologismo eugenes (buen origen) inventado por Francis Galton, la visión que a finales del siglo XIX se tiene sobre la ciencia y sus posibilidades: una visión con "vocación totalitaria [En ella,] Las disciplinas involucradas comprenden los factores que inciden en la herencia y en el ambiente, dando cuenta de cómo ambas instancias resultaban instrumentales dentro de una estrategia común de identificar lo normal y lo anormal, para luego asignarle a cada entidad el lugar que le correspondía." De la mano de la eugenesia, los Estados vislumbraron "la utopía de una sociedad sin conflictos" como posibilidad científica futura (Vallejo, 2016, p. 171).

En esta medida, la vocación totalitaria de la eugenesia es una geopolítica del tiempo (Rufer, 2010a), un elemento de conceptualización geo-temporal de una sociedad que conlleva una "voluntad de acción, orientando su desarrollo. Interpela al tiempo y espacio (como lo rebelan términos ligados al origen y al lugar), a partir de un diálogo permanente entre idealizadas caracterizaciones del pasado y del futuro, sujetas a permanentes intercambios y desplazamientos operados para, en definitiva, situar el mejor origen en relación a un tiempo indeterminado que ilumina las acciones del presente en pos del ideal que está en el mañana." (Vallejo, 2016, p. 170) La eugenesia se perfila como una "cronosofia" "otrificadora" (Ricoeur, 2000; Segato, 2007), en razón de que busca realizar un relato único idealizado/divisor de pasado/presente/futuro al definir al otro y al nosotros de lo normal y lo anormal como forma de incidir en la herencia y el ambiente.

Además, la eugenesia al situar el origen en relación al "tiempo complejo" (Jelin, 2012) (indeterminado, presente e ideal en este caso), anexa su voluntad de acción con una forma de construir sentido sobre el tiempo histórico y social anudado a una noción de tiempo biológico-científico que se corresponde con la fe en el "telos-destino" (Dosse, 2013) de la razón científica y el progreso de la sociedad en base a ella. Un telos, un progreso y un proceso como lenguaje de autoridad, que en el caso de la eugenesia, se teje con la sustentación teórica de las utopías, detección de "problemas de salud pública" y con el "racismo" (Palma, 2005, p. 126). Y es aquí, a mi parecer, donde cala la justificación de las 
"utopías" nacionales como voluntades de acción totalitarias (Vallejo, 2016), cada una con sus formas raciales descentralizadas (Radcliffe y Westwood, 2009) y anudadas con el efecto desdoblador de la modernidad exógena (Echeverría, 2011).

Al relacionarse con la definición de lo normal y anormal, con la detección de "problemas de salud pública", con el "racismo" y con la imaginación homologadora de la nación en un contexto de modernización del Estado, la eugenesia instrumentaliza la división de la temporalidad a través de una voluntad de acción que se identifica con la "expresión poética" (Rufer, 2010b) de origen y destino de cada nación que la acoge. Es decir, actúa como elemento de imaginación de la nación, de definición/división del tiempo, de la "otrificación" y de las formas de tutelaje tanto de Estado como de las instituciones del saber desarrolladas en torno a proyectos de nación o que construyen objetos de saber en consonancia con los proyectos de nación. Al estar sujeta a la expresión poética de la nación y a su imaginación otrificadora racial/racializante se corresponde con el doble efecto performativo (ver cap. 2) de la imaginación nacional (la comprensión de un pasado dotado de telos y la asignación por "investidura" de esencias sociales corpóreas/raciales/ "anatomo-política") que se corresponden a su vez con la legitimidad y legitimación del "campo de visibilidad" y el "horizonte de expectativas" de una institución de saber, sus relatos, sus "concepciones nativas" de tiempo y su "producción de historia".

\subsection{Ciencia psiquiatría en Ecuador}

Civilización/modernización para el progreso de la nación: siguiendo a Polo (2002), Serrano (2016), Rodas (2011) y Kingman (2008) se puede considerar que esta era la visión de mundo que moviliza la inteligibilidad de los objeto en la práctica médica que, en el siglo $\mathrm{XX}$, pasa a velar por el progreso de la nación, y hunde su práctica en el proyecto civilizador higienista que pretendía mejorar costumbres, prevenir la patología para garantizar el progreso e integrar a distintos sectores de la sociedad en un mismo proyecto de nación, a la vez que reproducía el sistema de hacienda e intercalaba en la cotidianidad las enseñanzas de la moderna medicina social eugénico-higienista con los sentidos incorporados de la decencia, el ornato y adecentamiento urbanos. (Ver capítulo 1). Encuentro aquí unas condiciones de producción para el campo de visibilidad médico, atravesado además por una Modernidad cultural (Polo, 2002).

Modernidad cultural (reorganización del espacio simbólico de la nación), Estado higienista, previsión eugenesista de la patología, definición higiénico-eugenesista de lo normal y anormal y una expresión poética de la nación conexa a la imaginación otrificadora nacional. Tal es el marco en el que Julio Endara publica en 1953 en los Archivos de Criminología un artículo titulado "Psicodiagnóstico de Rorschach y Raza". Un estudio altamente sistemático y estructurado, claramente inclinado al rigor científico que demanda el test. Un test que el mismo Endara ha introducido en Ecuador y difundirlo en Latinoamérica tras enterarse de su 
existencia por medio de la "Revista de Psiquiatría y Disciplinas Conexas" de Lima (Paladines, 2012, p. 32).

En éste trabajo se propone exponer los resultados de un estudio que considera imperativo para el país: abordar desde el punto de vista de la psiquiatría una problemática particular: la estructura de la personalidad de los indígenas, en términos de sus características intelectuales y emotivas. Con el fin de evaluar su posibilidad de inserción en lo que Endara llama "la vida de la cultura". Son dos los puntos de referencia. Primero los estándares universales de inteligencia y estabilidad emocional producidos por el saber psiquiátrico americano. Segundo, una medición y comparación que parte de una estructura socio-racial proveniente del ornato: 70 individuos blancos. Todos ellos jóvenes estudiantes de entre 18 y 25 años que ingresan por primera vez a la Universidad. La muestra de indígenas es también de 70 jóvenes de la misma edad. Todos “indios sanos" de las serranías ecuatorianas "dedicados a la agricultura, y por consiguiente en contacto con la civilización" (Endara, 1953, p. 43). Es decir, con una forma de producción que los pone en contacto con la ciudad, un lugar identificado con la modernidad en oposición al campo, identificado éste último con el atraso y la barbarie (Kingman, 2008, p. 45).

A continuación una extensa cita, que abre la exposición del estudio y que, a mi criterio, condensa el espíritu de la fuente que será interpretada:

Viejo anhelo de psicólogos, sociólogos, psiquiatras, etc., ha sido el de dilucidar, mediante el empleo de los recursos de investigación psicológica, las diferencias entre los distintos grupos étnicos que conviven en cada país. Y en América, el interés ha subido de punto en razón de que, en algunos de ellos, pese a la fusión parcial que desde la conquista se ha realizado entre conquistadores y sus descendientes y los de la raza aborigen, todavía ese cruzamiento no ha llegado a ser total. Por otro lado, la intervención de diversos grupos inmigratorios ha traído como consecuencia que, en nuestros días, convivan tres principales grupos netamente definidos: blancos, indios y mestizos, cada uno de ellos con características etnológicas definidas. En países como Ecuador, Perú, Bolivia, Colombia, etc., el problema cobra mayor importancia aún, porque, aparte del contingente negro ${ }^{39}$ - que por el momento no es materia de nuestra preocupación, aunque tiene su interés para algunos de ellos-, la porción aborigen, por su abundancia, es un factor de gran importancia económica y social en la vida de las nacionalidades. El indio de nuestras serranías, que todavía no se ha incorporado a la vida de la cultura, es, sin embargo, un elemento que debe ser, tomado en cuenta por una diversidad de circunstancias. $\mathrm{Y}$ por lo mismo que el principal problema indigenista es justamente el de procurar a todo trance que llegue a realizarse dicha incorporación, resulta indispensable que se lleven a cabo estudios psicológicos a fondo, pues de otra manera no es posible tener una orientación

\footnotetext{
${ }^{39}$ Es importante mencionar que en el caso de los pueblos negros en el Ecuador la ciudadanía contiene otras problemáticas que sería importante analizarlas en relación a la producción de objetos de saber. Por mencionar un elemento, en su tesis de Maestría en Antropología, Paulo Ayala (2017) señala que, desde la Constitución de 1993, los pueblos Afro ecuatorianos se vieron sometidos a un tipo de "ciudadanía ambigua". El artículo 56 de dicha constitución, manifiesta que se les reconocerá a los Afro descendientes los derechos que les sea aplicables en torno a unos derechos que son descritos para otras poblaciones. La ambigüedad de la ciudadanía de las poblaciones negras en el Ecuador, por ende, radica en que ésta era nula. No eran ciudadanos, pues no tenían derechos específicos descritos en la Constitución. Este estado de ambigüedad, según Ayala, se modifica recién en la Constitución del 2008 cuando se describen derechos específicos para el pueblo Afro en Ecuador.
} 
definida acerca de sus características intelectuales y emotivas, factores que componen el todo de la estructura de la personalidad. Hasta aquí se ha escrito mucho sobre el indio; la literatura indigenista abunda, pero en ese maremágnum de producción confunde lo lírico, domina el prejuicio y por eso puede decirse que recién en nuestros días se intenta una investigación científica de tan arduo problema. No puede ocurrir de otra manera, porque si no se llega por este camino a conclusiones sólidas, la incorporación del elemento indígena a la civilización tendrá que adolecer de improvisación y ligereza, lo que de ninguna manera es propio de una política bien intencionada y sería." (Endara, 1953: 41-42) Las negrillas son mías.

\subsection{Ciudadanía y raza}

Para comprender el marco en el que se ubica la fuente y la cita que acabo de hacer, inicio la interpretación por el abordaje de la problemática de la ciudadanía y la raza para establecer la forma en la que la concepción de la ciudadanía en el país está sujeta a formas racializantes de producir alteridad y de perfilar a los sujetos de la nación moderna. Arranco por la ciudadanización del indígena porque es este el momento en el que un sujeto colectivo pasa a ser masificado (homologado en el sujeto universal moderno al ser despojado de sus derechos étnicos específicos) a través su individualización como ciudadano. Una individualización que, como veremos en este capítulo, hace posible en el discurso psiquiátrico la producción de diferencias raciales somato-psíquicas.

Paola Sánchez (2011), propone que hay dos vías de análisis para pensar la problemática de raza y ciudadanía, una referida en términos convencionales a partir de los estudios Jurídicopolítico del Estado, y otra ligada a la construcción de ciudadanía desde la ciudadanía del sentido común.

La primera responde a la normatividad institucional basada en la triada democraciaciudadanía-derechos, en la cual se concentra un sistema político que permita la “organización del proceso decisional, combinando la elaboración de demandas y expectativas civiles con la producción de decisiones administrativas estatales." (Sánchez, 2001, p. 82) El segundo en cambio explica la formación del Estado como un proceso histórico inmerso en las relaciones de dominación que pone en cuestión la linealidad política que explica el Estado-nación solo desde la normativa institucional y descuida la tensión entre lo particular/universal.

Sánchez (2001) plantea que la dinámica de constitución del Estado-nación requiere la definición de rasgos culturales comunes, pero estableciendo una diferenciación entre las mayorías (habitantes con rasgos comunes) y las minorías (grupos con especificidades, ante todo étnicas). La forma de saldar tal relación es la de construir un principio de universalidad: el individuo. Éste aparece como entidad autónoma, pero reconocida en tanto subsumida a la idea de un "fin superior" que en el caso del estado-nación se traduce en la preservación del orden público legal en donde las particularidades se constituyen como parte de la comunidad nacional siempre y cuando expresen los valores ético-jurídicos del 
estado-nación. Una de las forma, entonces, de mantener el "fin superior" es la definición de estrategias y mecanismos de control enmarcados en prácticas instituidas de normalización. (p. 83). Estas prácticas instituidas de normalización en pos de un fin superior (de preservación del orden público legal y de aglutinamiento de la comunidad nacional), para la imaginación de la nación, implican, una definición del pasado dotado de un telos-destino (Dosse, 2013; Rufer, 2010a, 2010b) que constituye los rasgos culturales comunes anclados en un fin superior que procura el día a día, y en razón de una proyección a futuro, una proyección que se dibuja como destino.

En primera instancia, el test que Julio Endara aplica por normativa institucional a los estudiantes blancos que ingresan -y a la que deben sujetarse si quieren entrar- por primera vez a la Universidad (y que forman parte del estudio comparativo entre ellos, los estándares universales de medición de la personalidad y los indios de la sierra ecuatoriana) es una práctica de normalización instituida en tanto que garantiza la medición de las capacidades intelectuales de los individuos que ingresan al sistema educativo superior (jóvenes blancos) $\mathrm{y}$, por ende su capacidad de desenvolvimiento al interior de las expectativas y exigencias que plantea tal sistema universitario.

Por otro lado, avala científicamente una conclusión sobre las capacidades de la "porción aborigen", posibles ciudadanos, para que sean insertados en la civilización como individuos universalizados, en tanto que se puede determinar si calzan dentro de parámetros estandarizados de normalidad emocional e intelectual que les permitiría formar parte del ideal de ciudadanía del estado-nacional moderno.

Pero dicha incorporación debe estar acompañada, como dice Endara, de la supervisión de los "organismos estatales y los dirigentes de la cultura". Es decir, del Estado y los intelectuales, entre ellos los médicos. En este sentido pienso que la práctica psiquiátrica no deja de entrever -en la definición de sus objetos y en la delimitación de su espectro de intervención- las practicas instituidas de normalización para la construcción de ciudadanía, conexos al estado-nación moderno, un Estado higienista (Kingman, 2008; Serrano, 2016); y tampoco se aleja de la imaginación de la nación en tanto que la reconfiguración del espacio simbólico de la nación, como vimos (cap. 1), está a cargo de los intelectuales, quienes procuran la definición de una cultura moderna a través de instituciones de Estado como la CCE (Polo, 2001) y de médicos que están a cargo del proyecto civilizador del Ecuador (Kingman, 2008).

La incorporación de la "porción aborigen" requiere, según Endara, de la tutela del Estado $^{40}$, bajo la cual se asume que hay pueblos incapaces de conducirse sin el amparo-

\footnotetext{
${ }^{40}$ La tutela entendida como una noción de amparo de los estados nacionales sobre los pueblos minorizados por estos mismos estados nacionales. Es decir, el tutelaje es la continuidad de las minorizaciones. Toda población, que bajo los presupuestos de la ley se considera susceptible de tutelaje (para su sobrevivencia y para su correcta conducción, porque no puede o no está en la capacidad de hacerlo por si misma) es una población inferiorizada. Una población minimizada, pese
} 
tutelar del Estado. Este es un tipo de "administración étnica" que fue posible una vez que el indígena fuera borrado en su especificidad étnica para homologarlo en el título de ciudadano tras la eliminación de la figura de indio tributario, y que le permitió al liberalismo recamar para sí la representación del indígena (Guerrero, 1994, p. 200).

La particularidad del tutelaje que aparece en el trabajo del psiquiatra Julio Endara, además de minimizar al indígena al desconocer su pensamiento político y su visión de la historia capaz de aportar al "desarrollo" de la nación, apuesta por ampararlos y tutelar su ingreso en la civilización, y por ende en la historia-tiempo de la nación, de la mano de la ciencia. Para ello hay que generarle buenas costumbres, formarle habitus de buenas costumbres, como sucedió con el higienismo según Kingman (2008). Pero no se trata solo de las buenas costumbres, sino de entender al indígena en su dimensión profunda, comprender su psique para deducir su capacidad real psíquica de incorporarse "al mundo de la cultura", su capacidad, si se quiere de incorporar las buenas costumbres que el higienismo le quiere inculcar. Se trata de hacer de la "porción aborigen" un objeto inteligible: estudiar la idoneidad de su ser psíquico para ser civilizado. Además, aquí otra particularidad de la administración étnica por la que aboga Endara, la raza-signo aquí, actúa no solo como forma previa a la Ley (Segato, 2007), sino previa al saber psiquiátrico.

Al respecto, nótese que el uso del Test de Rorschach, un test enmarcado en el psicoanálisis, da cuenta de un tipo de uso conexo al positivismo. Tanto en la Historia Clínica Criminológica que propuso en la década del 30 como en los resultados a los que llega en éste test, se aprecia que entre ambas disciplinas no hay una distancia conceptual tajante en el uso que le da Endara, y en general en el uso que le dan los psiquiatras a una y otra disciplina, no hay una separación entre el Endara Darwinista seguidor de José Ingenieros de los años 30 y el experto en Rorschach, sino un "hilo de inquietudes y metodología que les une" (Rodríguez, s/a, p.3). Pareciera incluso que las usan por considerarlas disciplinas modernas, porque estas ofrecen una vía para civilizar al otro de la nación y porque el uso de las teorías de forma ecléctica, como lo he sugerido ya, es una forma de la modernidad en este país que, en la práctica psiquiátrica, se manifiesta en su esfuerzo por definir objetos y delimitar campos. Esfuerzo atravesado por las tensiones del sentido común racializante.

Pero, lo que entra en juego no es solo el eclecticismo y el proyecto civilizador como luchas por definir objetos y delimitar campos, es que el eclecticismo está inscrito en un proyecto civilizador que es racial. Por ello, propongo ahora aquí que es la raza-signo la que permite la convivencia entre teorías que se oponen en otros contextos de modernidad como el

a ser considerada como parte de la nación, no es considerada soberana de su propia razón. La raza-racialización permitiría problematizar el advenimiento del ciudadano moderno como parte de un entramado de ocultamiento de la continuidad de la categorización social en base al concepto de raza en América Latina. Para ello resulta oportuno pensar la raza como signo que va más allá del color de la piel. Raza-signo es un capital negativo condensado en el cuerpo. Siguiendo a Rita Segato (2007), en los estados poscoloniales opera una pedagogía de la mirada sobre las diferencias y las jerarquías, creadas en la colonia, condensadas en la línea del tiempo, y que garantiza en cada sujeto la capacidad de detectar los cuerpos de la exclusión. La raza-signo por ello opera de forma previa a la ley. 
anglosajón o el europeo ${ }^{41}$. En la Historia Clínica de Endara, Lombroso, Kretschmer y Hermann Rorschach conviven. La Teoría Constitucional, la Criminología Endócrina y conceptos clave del psicoanálisis como asociación libre en un test proyectivo, coexisten como una vía más adecuada, no "improvisada" - como dice Endara- para entender la raza en Ecuador. Estas corrientes se acoplan en el signo-raza.

El indígena, desconocido como sujeto colectivo, construido como "individuo" en el contexto de su ciudadanización, ahora, en esta ventriloquía política psiquiátrica, pasa a ser desconocido como sujeto de saber, y allí pasa a ser objeto de civilización masificado, homologado, a razón de que ese saber que se constituye sobre su psique y su cuerpo se articula en la raza-signo actuando de forma previa a la inteligibilidad del objeto, como pedagogía de la mirada.

\subsection{El saber psiquiátrico y el "problema del indígena": psique, espacio, tiempo, raza y ventriloquía política psiquiátrica}

Cuando Endara aplica el test de Rorschach realiza varias operaciones de inserción, partición, producción y legitimación partiendo de dos ideas. La primera se refiere a la potencia del saber científico que, a través del test, puede resolver el "problema indigenista" del cual han intentado hacerse cargo "sociólogos, psicólogos, psiquiatras, etc.," sin lograr trascender lo "lírico y el prejuicio". No es sino hasta mediados del s. XX, según este reconocido psiquiatra, que se "intenta una investigación científica de tan arduo problema". En esta enunciación disputa el lugar de la legitimidad de la psiquiatría como ciencia capaz de dar cuenta del mundo, de describirlo, de cuantificarlo, cualificarlo, ordenarlo, de comprenderlo mediante parámetros de comprobación. Además de dar cuenta de la realidad, de la profundidad psíquica y de la patología está en la capacidad de dar respuesta y solución a los problemas de la nación. Le ofrece a la nación -y también a las naciones vecinas- una vía definitiva y no improvisada para la incorporación a la cultura civilizada de la "porción indígena que por su abundancia, es un factor de gran importancia económica y social en la vida de las nacionalidades" - dice Endara-.

El segundo recorte es la diferenciación racial entre blancos, indios y mestizos, que opera previa a la aplicación del test y que motiva conclusiones. Asume que la comparación entre razas es un parámetro de medición de la inteligencia y la normalidad. Cada grupo racial dice- tiene "características etnológicas definidas." Para Endara estos rasgos característicos en parte explican conclusiones a las que llega por vía del test. Para Endara las actividades de una raza son un indicador del desarrollo del intelecto. En su sexta conclusión, respecto de la estimación del nivel intelectual dice:

\footnotetext{
${ }^{41}$ Pero incluso en esos contextos quizá parte de la oposición entre teorías se pueda explicar a partir de oposiciones raciales, como el caso del nacismo contra la teoría judía o la cabida y desarrollo que tuvo la eugenesia negativa (esterilización) en E.E.U.U mucho antes que en Inglaterra o la Alemania Nazi.
} 
La capacidad elaborativa, es decir, creadora, estudiada a través de las cualidades de las respuestas globales, habla en el sentido de una inferioridad evidente en el indígena, pero que no está relacionada con un déficit intelectual, pues que se encuentra lejos de las normas que corresponden a las diversas especies de débiles mentales, sino a su carencia de ilustración y ninguna práctica en las actividades propias de la cultura. Y ello es claro si se tiene en cuenta que el material indígena estudiado corresponde justamente a personas dedicadas exclusivamente a labores agrícolas. (Endara, 1953, p. 55).

Hay, entonces unas "prácticas" en "actividades" de la cultura propias de la "capacidad creadora”. Es esa diferencia, en sí misma, la que para Endara explica el rezago de los indígenas cuyas labores agrícolas no alimentan, no ilustran el intelecto, y además los ubican por debajo de los niveles "elaborativos" de los blancos, cuya pertenencia y acceso a la cultura los estimula intelectualmente: el mundo de los blancos estimula el intelecto, las actividades agrícolas, propias del mundo del indio, no estimulan el intelecto. El problema no es que no sean inteligentes, sino que no han accedido a la cultura que les provee de elementos ilustradores del intelecto. No han incorporado costumbres, higiene, valores, comportamientos, no han sido educados en ciencias pues no han pasado por instituciones educativas. Aquí, en esta parte del test, cultura es lo culto, es la posesión e incorporación de una forma legítima de saber, responde a esa acepción. De allí que la inferioridad intelectual del indígena frente al blanco responde a su rezago frente a la incorporación de lo culto. Está, pero está retrasado. El indígena está en el presente pero de forma atávica.

No se explicita del todo qué es lo culto. Si observamos el contexto, observamos que no lo hace porque ya hay un significado que circula. Por tanto no es necesario. Endara escribe para un grupo de científicos e intelectuales, como él, que lo leen y, que poseen un capital simbólico, asumido, cuya acumulación en el tiempo le permite distinguir(se) de "los otros" grupos raciales, y han incorporado un habitus desde el cual perciben y juzgan la posición de cada raza en la estructura.

La cultura para Endara reside en otro sector de la sociedad. No hace falta explicitarlo porque es parte del "mundo del sentido común" (Guerrero, 2011), forma parte de una estrategia de distinción, en la medida en que es estrategia de jerarquización y diferenciación social, desde la cual se han construido las ciudadanías en Ecuador. El sentido común, esa "sedimentación de los procesos históricos presentados como disposiciones prácticas, prácticas cotidianas, rituales y retóricas sociales". (Polo, 2009, p.128), es el que le permite tanto a Endara, como a sus interlocutores, extraer el sentido de estas palabras y expresiones, que de plano, dan por sobreentendido de lo que se está hablando.

Entonces, lo culto no reside en las actividades agrícolas porque la "modernidad cultural" (Polo, 2002) como elemento de reconfiguración del espacio simbólico nacional, por un lado privilegia la actividad intelectual blanco-mestiza, identificada con las instituciones de saber positivo legitimado como la Universidad a la que pertenecen los estudiantes blancos con los que se compara a los indígenas como "estrategia metodológica" y de la que Endara es una 
de sus voces autorizadas. Por otra parte, la "modernidad laica" según Kingman, impulsada en el siglo XX, privilegia y promueve la idea de que la modernidad reside en los espacios en donde existe una "comunidad política" y el espacio idóneo para ello es la ciudad, lo urbano concentrado y ordenado, no el campo. Ello además permite que la modernidad sea "asumida como un recurso de ascenso al interior de un orden jerárquico, en el cual los bienes materiales sirvieron, sobre todo, para la acumulación de capital simbólico" (Kingman, 2008, p. 338-339). Quien posee elementos de modernidad en su vida asciende en el orden jerárquico moderno.

Endara, desde el sentido común, realiza así una distinción racial por actividades consideradas intrínsecas al espacio en el que se estructura la psique de los individuos. El espacio habla inmediatamente para este psiquiatra de costumbres, buenas y malas, y de saberes legítimos, que generan distinciones raciales y de clase a la vez que la modernidad cultural y el Estado higienista, de forma contradictoria, vislumbran en la "cultura común" y la "ciudadanía" el advenimiento del "Estado moderno" (Kingman, 2008, p. 358). Esta distinción racial que se define por el espacio que se habita genera una distinción que se define por la relación raza-psique. Pero no es una distinción insalvable, recordemos de nuevo que para Endara la raza en este caso no es condición de inferioridad, el problema para él está en lo poco civilizado del espacio donde se "ilustra" la inteligencia. En esta medida el razonamiento de Endara se sustenta en las nociones sobre espacio y civilización del higienismo en el Ecuador y en los debates eugenésicos sobre ambiente y psique en otros países del continente. A su vez esta noción sobre el espacio crea una distinción de tiempo marcada por la oposición progreso/incivilización. Hay un espacio idóneo para el tiempo del progreso y otro atávico. De allí que la idea implícita que se sostiene en este modo de comprender la relación espacio-civilización sea que el indio no es culto porque es campesino (que es otra forma de ser indio).

Ahora bien, en esta distinción de raza y de tiempo que deriva en la espacialización geotemporal de los blancos, indios y mestizos de la nación ecuatoriana, se puede observar otro rasgo de la tutela racial que remite a la "oposición binaria" de la "modernidad colonial" (Rufer, 2010a): la minimización de los pueblos representados como rezago. Desde la perspectiva de la cultura política, Carlos de la Torre, señala que hasta fines de los setenta, la intención de las elites políticas modernizantes de crear partidos ideológicos fue una iniciativa que "demuestra un desdén y menosprecio a los sectores populares que aparecen como niños-adultos que todavía no conocen cuáles son sus verdaderos intereses, ni las formas racionales del convivir político. Las élites políticas modernizantes asumen el papel de educadoras del pueblo. Ellas guiarán a los sectores populares hacia lo que entienden como el futuro racional y moderno de la historia del país sin respetar, ni tomar en consideración, las formas populares de hacer política." (De la Torre 1996, s/p. En: Allan, 2011, p. 18). 
¿Es a esa élite política a la que Endara le habla cuando se refiere a los "dirigentes de la cultura"? Pienso que sí. Endara entiende que el rol de los "dirigentes de la cultura" y "organismos estatales", respecto de los indígenas, es el de su educación, conducción y rescate, más no su eliminación. Pero su "impulso y auxilio", para superar el prejuicio reinante, deben estar a su vez guiados por el camino de la ciencia. Caso contrario todo intento de civilizar (educar, auxiliar y asistir) a los indios sería "improvisado". Y ello no es propio de una "política bien intencionada" (Endara, 1953, p. 42).

Hay un grupo social encargado de la modernización y encargado del rescate de quienes no pueden civilizarse por sí mismos, de quienes no pueden representarse por sí mismos, de quienes no pueden ser sujetos de su propio saber. Además, se da por sentado que la civilización es el ideal deseado por todos los seres humanos que habitan ese territorio imaginado llamado Ecuador. Este grupo social (que es una élite intelectual, cultural y política a la que encarna Endara), actúa como "ventrílocuo" de los indígenas ${ }^{42}$. La ventriloquía política entendida como una forma de dominación que delega "al ámbito de lo privado [lo que es concerniente] al trato entre ciudadanos y poblaciones indígenas" (Guerrero, 1997, p. 6). En esta imagen del indígena trazada por Endara, se halla replicado el dominio semiótico del consenso iconográfico que el liberalismo conjugó para imaginar la nación laica y sus otros étnicos y que otorga al indio la imagen del otro-oprimido al que hay que liberar y administrar desde el Estado protector.

Esa imagen política, dice Guerrero, actúa como sentido práctico: tras marcar fronteras étnicas, Endara se atribuye a sí mismo y a los "dirigentes de la cultura" la administración étnica y la civilización del indígena, para hablar y hacer por y en su lugar. Pero la ventriloquía aquí no solo habla y hace en lugar de, sino que a través de la administración y consecuente silencio y desdibujamiento del indígena como sujeto político, histórico y de saber, Endara hace uso de la imagen política del indígena oprimido e incivilizado para la producción de un saber psiquiátrico sobre su psique. Sin la imagen ventrílocua del consenso iconográfico liberal (Guerrero, 1994) (ver cap.2) de las élites de la nación que versan sobre la "salvación" del indígena, las motivaciones, los objetivos y las conclusiones a las que llega Endara en su trabajo sobre personalidad del indígena y el espacio atávico que habita, con mucha probabilidad, serían otros. ${ }^{43}$

\footnotetext{
${ }^{42}$ Con respecto a los mediadores étnicos entre los indios y el Estado, Andrés Guerrero señala que "es un agente social que sirve de interfaz y pone en marcha el dispositivo político de representación que transforma el reclamo verbal ( $i e n$ quichua?) de los indígenas en una estrategia de señales-palabras inteligible para el estado liberal, una ideología-código". Con respecto a las cartas de peticiones que elaboran estos intermediarios, anota que "ponen la pluma, la tinta y los vocablos [y] queda elucidado que las palabras del documento son obra de un ventrílocuo, un intermediario social que conoce la semántica que hay que poner en boca de los indígenas, que sabe el contenido, la gama y el tono de lo que el estado liberal quiere y puede captar. EI "ventrílocuo" conoce los circuitos de poder en la burocracia y maneja el sentido del juego (Bourdieu) del campo político tanto en la escena regional como en el poder central." (Guerrero 1994:241-242. En: Allan, 2011: 18).

${ }^{43}$ Por ejemplo, Arturo Orbegoso (2012) señala para el caso del Perú, que el control impuesto por las élites en cuanto a normas sanitarias con propósitos eugenésicos en las tres primeras décadas del siglo XX, arrojó resultados (tras la aplicación de test de inteligencia como la escala Binet-Simon a niños indígenas) que permitieron afirmar una jerarquía entre razas de acuerdo al intelecto. Pero los indígenas no solo resultaban ser intelectualmente inferiores a los blancos, sino
} 
El campo, el trabajo agrícola, el intelecto, la emotividad que son las categorías que se usan para nombrar al indígena y su cotidianidad, son signos de incivilización, no así de anormalidad patológica. Es su incivilización, su forma de vida y el espacio que habitan lo que produce el rezago, lo que los ubica "un poco atrás de los parámetros y estándares de inteligencia". Pero, el giro que toma todo, es que al ser definido normal, el indígena es perfectible, civilizable.

\subsection{Presencia-presente indígena: entre lo atávico y lo patológico}

El Dr. Endara dice "fuera de lo que a primera vista era de suponer (...) Lo esencial, pues, es que en el curso del psicodiagnóstico, no aparecen signos ni sospechas de deficiencia mental. Por el contrario, su nivel mental, apreciado a través de estos elementos del Psicodiagnóstico, aparece perfectamente normal, y desde luego comparable en posibilidades y en potencia con el del blanco". Lo que no se explica por la patología o por los estándares de inteligencia, se explica por lo que es propio de la raza y el ambiente racializado, por la "predominancia en su experiencia perceptiva" de los "intereses y objetivos propios del medio campesino.” (Endara, 1953, p. 56).

El indígena, su forma de vida y el espacio que habita, aparece como el presente de un pasado que no es coherente ni funcional a la temporalidad a la Modernidad Cultural ni la Estado Higiénico y Laico. El indígena aparece como un presente no acorde al presente de la nación "moderna", conformada por un ideal que perfila un tipo de ciudadano culto-bien portado, ilustrado, productivo, blanco mestizo, civilizado, sano: normal. Y esta normalidad está inserta en el tiempo-progreso-nacional; es normal por ello, por esa identificación con el progreso, por esa inserción. La mundialización del modelo de Pinel, y por supuesto, la universalidad del discurso de modernidad al pasar por un proceso endógeno de otrificación nacional, construye las nociones de normalidad acorde al contexto nacional y acorde a los objetivos de su proyecto de modernidad. Por ello, el vínculo entre patología / sociedad y normalidad / sociedad es parte de ese proceso de otrificación en el cual las nociones de patología y normalidad cobran sentido.

Al colocar al indígena bajo la lupa de la ciencia moderna, Endara disputa un sentido político por sobre la legitimidad de un objeto de saber y a la vez, disputa los mecanismos y reglas de su inteligibilidad. En este sentido, en el discurso sobre el indio el test de Rorschach actúa como un sistema de verificación (Foucault, 2010) psiquiátrico de lo anormal y normal-civilizable nacional en el contexto de modernización del Estado y de

que su inferioridad era insalvable, pues para un grupo de eugenesistas peruanos, el problema radicaba en que la raza india estaba degenerada y había llegado al tope de su evolución, y en este sentido no se trataba solo de inteligencia (que de por sí era inferior) ni del ambiente, sino del carácter que los indígenas no poseían a raíz de su degeneración y tope evolutivo, y que los separaban enormemente de las razas perfectibles. Estas conclusiones, según el autor, son posibles porque a inicios del siglo XX hay un clima intelectual completamente aversivo al indígena y una élite que promueve una higiene racial como condición para el advenimiento del progreso en Perú. 
redefinición del espacio simbólico de la nación. A través de la definición de reglas de inteligibilidad del objeto de saber y de verificación de lo normal/anormal, también perfila un relato psiquiátrico sobre el pasado, lo que a su vez significa que disputa un sentido sobre lo que pertenece al presente al futuro y al pasado. Como veremos, no hay una sola forma de referirse al pasado-futuro-presente por parte de los psiquiatras. Es decir, no hay una sola forma de referenciarlo sin extender en las temporalidades puentes de conexión y cercanía, barreras de distancia y jerarquía de distinta índole.

Al no encontrar patología en el indio, se le atribuye a su permanencia en el pasado sus deficiencias. El indio está en cuerpo y psique "normal" presente en el presente nacional, pero sus actividades no: es un presente atávico. La normalidad, entonces, no remite aquí solo a la salud mental, es decir al concepto europeo y norteamericano de patología mental, sino a un ideal regulatorio de ciudadano universal en la versión del estado-nacional moderno ecuatoriano, fruto de su particular proceso endógeno de otrificación nacional en donde encuentra su cauce y en el que se reproducen estructuras raciales en el sentido común sobre el indio y su vida que actúan como signos previos al saber.

Ello bien podría perfilar una explicación de por qué, a pesar de la voluntad de Endara por evadir el "lirismo" y el "prejuicio" desde el que se habla de los indios, no lo hace. Por el contrario, aporta con una nueva forma de normalizar al indio al reproducir fronteras étnicas en las divisiones raciales/racializantes que crea a través del empleo de una herramienta científica como el test. Reactualiza en la medida que reinventa una forma de atribuir el rezago al hecho mismo de ser indígena que estructura su psique en un ambiente incivilizado. Pero a su vez descarta la patología, más no la anormalidad en el marco del nuevo proyecto nacional. "La formación de la ciudadanía es un componente del mundo del sentido común. Se vincula a las formas de pensamiento y al sistema de habitus, ambos históricamente construidos e incorporados por los dominantes en el periodo colonial; actualizados y reinventados en la república." (Guerrero, 2000, p. 4. En: Sánchez, 2011, p. 86) y re-versionados bajo otras regularidades de la modernización en Ecuador.

Para Guerrero (2011), entonces, se produce una confrontación entre el sistema de clasificación estatal y la "ciudadanía de sentido común". El contraste se da entre un concepto jurídico-político y una noción cotidiana, podría decirse “espontánea”, de ciudadanía. Para captar esta confrontación, Guerrero propone la noción de "ciudadanía de sentido común" o "ciudadanía de facto" que hemos mencionado. Es decir, una disposición práctica para los intercambios cotidianos entre los agentes sociales. Ésta hace posible

la articulación y la objetivación en los encuentros entre los agentes sociales el despliegue de disposiciones y sistema de clasificación interiorizados y naturalizados heredados desde la colonia, este despliegue adquiere la modalidad de prácticas de distinción y distintivas. Es importante recalcar que el tempo social de estos sistemas de clasificación son de mediana y larga duración, es decir, no 
se reducen a coyunturas políticas sino que las trascienden. La "ciudadanía de facto" que hereda la situación poscolonial percibe a los "otros", los indígenas, desde una posición jerárquica dominante, mientras éstos se reconocen a sí mismos como blanco-mestizos e hispano parlantes. La presión social de esta 'ciudadanía de sentido común' afirma un imaginario de castas sociales y hace posible el despliegue de estrategias de desindianización. (...) en las relaciones sociales, como relaciones de poder/sentido, (...) predomina la 'ley de la costumbre'. Los sistemas de clasificación racialista y las fronteras étnicas permanecen como sentido común en los intercambios cotidianos. Esta separación y tensión permanente entre la práctica estatal y la "ciudadanía de sentido común" encubrió (y encubre) la violencia cotidiana hacia los indígenas, como hacia las mujeres, y legitima las fronteras étnicas. (Polo, 2009, p. 129-130).

La desindianización del estado nacional ecuatoriano, muy atada a una continuidad de la ciudadanía de facto, acompaña el signo-raza que motiva, dispone y define las reglas de inteligibilidad de la psique del indígena y el espacio que la estructura; y a su vez, reinventa una matriz racial a través de un "binarismo compulsivo" (Guerrero, 1997) que atraviesa la mirada del psiquiatra. En el juego de la cotidianidad, el ejercicio de la profesión psiquiátrica está atravesado por la ley de la costumbre. El binarismo compulsivo de la inteligibilidad psiquiátrica otrifica al indígena al objetivarlo, empujándolo a ocupar el lugar del "otro-atávico"; a ocupar el lugar de la interpretación binario-compulsiva que lo enuncia (sin que este desaparezca por completo debido a su enunciación). Quienes habitan el presente atávico de la nación ecuatoriana a mediados de S XX, son los sujetos otrificados por la ciencia psiquiátrica y por el tiempo-progreso de la historia, cuyos sentidos también son anexados y disputados por la psiquiatría.

\subsection{Presente atávico: lo incivilizado en tiempos de modernidad}

"Habría que afirmar, pues a manera de conclusión sintética final, que tanto las capacidades intelectivas como emotivas del indígena de nuestras serranías presentan los caracteres de una perfecta normalidad; y que por ello, esperan de la comprensión de los organismos estatales y de los dirigentes de nuestra cultura, el impulso y el auxilio que les permitan incorporarse definitivamente a la civilización.” (Endara, 1953, p. 65).

En esta conclusión Endara toma la categoría "normal", al parecer, no únicamente para descartar la patología en el indio, sino para elaborar una tesis más compleja que permita develar una etiología sobre la incivilización del indígena. Pero ésta etiología no corresponde del todo a un orden biológico, sucede que la pregunta y la respuesta sobre la etiología corresponde a un "régimen discursivo de representación temporal" (Rufer, 2010b) en el que la identificación del proyecto racial de nación moderna ecuatoriana, identificada con la temporalidad del progreso y el ornato, son los referentes políticos de la práctica disciplinar. Cuando Endara indaga sobre la etiología de la incivilización, evita ubicar la normalidad de la psique del indígena netamente en el terreno de la biología precisamente para que el atavismo indígena no sea insalvable. Su normalidad atávica, más no su 
anormalidad biológica-patológca-degenerada, dibuja un camino para que pueda ser homogenizado (incorporado en la civilización), incorporado en el "tiempo de la pedagogía nacional" (Chatterjee, 2008, p. 63), que en este caso es el tiempo imaginado de la modernidad cultural/laica y del Estado higienista de la nación moderna ecuatoriana en el que el indígena podría ocupar un lugar en la narrativa y ser educado como ciudadano. Colocar el cuerpo biológico y psíquico del indígena fuera de la anormalidad permite explicar, como mencioné, que el problema de su atavismo respecto del tiempo moderno responde a sus malas costumbres, su tipo de trabajo, su falta de educación.

De allí que Endara construye la normalidad del indio como presente atávico. En el test de Rorschach el indígena aparece como un sujeto incivilizado en tiempos de modernidad, pero con estructura psíquica normal idónea para ocupar un lugar en el destino nacional, en las estrategias narrativas y de los aparatos de poder que educan y homologan heterotopias para la ciudadanía en el tiempo de la pedagogía nacional. Lo incivilizado es un presente que no accede a la modernidad por su condición rezagada. Los indígenas, esa presencia atávica, esa presencia distante de un nosotros civilizado, por deber, tanto de la psiquiatría como de "los organismos estatales y los dirigentes de la cultura", deben ser evaluados, preparados y adaptados para su inserción en el tiempo imaginado de la nación.

Endara se suma aquí a otra ventriloquía política, adhiere a los postulados políticos de una corriente indigenista extendida por toda Latino América en la que la biología no condiciona el progreso de la raza y la nación. Echa mano de categorías del psicoanálisis para introducir una perspectiva indigenista en un debate eugenésico sobre ambiente y organismo. Desde hace mucho tiempo que Endara adhiere a toda postura que se muestre a favor de la incorporación del indígena y que ayuden a deshacer los prejuicios raciales y demuestren que las masas indígenas pueden ser asumidas como "factor activo en el sentido económico y espiritual, en la vida de los pueblos hispanoamericanos" (Lipschutz, 1937, s/p. En: Endara, 1937, p. 406).

En el espacio de reseñas de los Archivos de Criminología, Endara menciona el trabajo del Prof. A. Lipschutz, un fisiólogo y endocrinólogo residente en Chile, para cuestionar la noción de pureza racial, y para afirmar que al combatir el "prejuicio biológico racial" que pesa sobre el indígena, se debe "estudiar el medio". Ello es importante, según consta en la reseña, porque Lipschutz considera que la raza india es la clave del surgimiento de una "conciencia indo hispanoamericana" capaz de generar la posibilidad de creación de la "propia tradición cultural" de América española a través de la incorporación de las masas indígenas en las naciones $\mathrm{y}$, porque combatir el prejuicio biológico permitiría a la "tradición cultural propia" la "afirmación de su internacionalismo intercontinental" para cambiar la "faz del Nuevo Mundo". El estudio del medio como forma de pugnar el prejuicio biológico racial en pos de una "tradición cultural propia", implica para Endara 
mantener en el horizonte de la inteligibilidad de los objetos una "orientación sociológica" con los cuales abordar la incorporación del indio.

El razonamiento de Lipschutz se encuentra implícito como voz autorizada de la fisiología y la endocrinología en el llamado al "auxilio" de los indios para su civilización formulado por Endara, porque el argumento de este hombre de ciencia, en su autoridad instituida, evoca la postura del "indigenismo interamericano" (Prieto, 2010) que, de forma similar a la eugenesia positiva, niega la inferioridad genética de las razas y apuesta por la noción de que el ambiente modifica o da forma a las características raciales, a la vez que biologiza la cultura y crea fronteras culturales de distinción entre naciones, que en este caso apela a una comunidad imaginada hispanoamericana. Distinciones que forman parte de sus proyectos modernizadores ${ }^{44}$.

El reforzamiento de las diferencias en la ventriloquía política indigenista, que empata con la eugenesia positiva, le permite a Endara introducir la normalidad atribuida al indígena en un juego de tiempos (una imaginación de futuro, una espacialización del pasado, y el desplazamiento de un presente atávico de un presente moderno). La normalidad es evocada como distancia y como posibilidad futura. El indígena normal-atávico y su espacioambiente emergen de una imaginación temporalizada en la que la raza forma parte de elaboraciones culturales, biológicas y anti-biológicas que permiten remarcar las fronteras étnicas.

Entonces a la vez que raza es signo, en el trabajo de Endara también es diferencia y absorción-conversión. Es decir, a la vez que forma parte o permite la construcción de un 'otro' de la nación al que vuelve signo identificable en un cuerpo racializado en el proceso otrificador, este signo-raza también posibilita, según Prieto (2010) la distinción entre naciones, y grupos de naciones imaginadas como comunidad regional o continental frente a naciones imperialistas y europeas (p. 13-15). A su vez es un signo de absorción-conversión del 'otro' en la medida que lo absorbe en el tiempo de la pedagogía nacional para convertirlo en un 'nosotros' perteneciente a una misma comunidad homogénea blancomestiza. En un periodo de reconfiguración del espacio simbólico de la nación, Endara se mueve en toda esta dinámica al hacer un llamado a Ecuador y varias naciones para asumir el "principal problema indigenista [que es] justamente el de procurar a todo trance que llegue a realizarse [la incorporación del indio en la vida económica y social] de las nacionalidades." (Endara, 1953, p. 42).

\footnotetext{
${ }^{44}$ Mercedes Prieto (2010) postula que las prácticas de educadores post-revolucionarios en México como Moisés Sáenz, buscaron una red de contactos y una arena de debate sobre la cuestión indígena para generar un latinoamericanismo que cree fronteras culturales con el Norte. La idea de raza fue un elemento constitutivo de carácter nacional para proteger las fronteras culturales, abogando así por un esencialismo cultural indoamericano, que en oposición al hispanismo, promovía la emergencia de la raza y la cultura mestiza rememorando al indígena. Raza en este contexto fue una elaboración biológica y cultural que daba cuenta de una reforzadas diferencias, de un "ethos distintivo" de las naciones latinoamericanas (p. 7-15).
} 
A su vez esta imaginación temporalizada permite a Endara identificar, construir y disputar objetos de saber. La nación aquí actúa como espacio de referencia para la inteligibilidad del indígena como objeto de saber psiquiátrico, puesto que esta inteligibilidad está inmersa en las razones políticas de la imaginación temporalizada e instituida de la narrativa nacional ecuatoriana de mediados del siglo $\mathrm{XX}$.

\subsection{El indio somato-psíquico}

\subsubsection{Del organismo al ambiente: un ambientalismo eugenésico indigenista psiquiátrico como oposición al indígena biológico-patológico-orgánico-anormal}

Posterior a la publicación del estudio, tomando los resultados obtenidos por Endara, su alumno Agustín Cueva Tamariz, realiza una investigación complementaria para elaborar conceptos que permitan aprehender al indígena en toda su dimensión del que la psique es parte del criterio constitucional. Este psiquiatra, nacido en la ciudad de Cuenca y alumno de Endara, publica en los Archivos de Criminología un trabajo en el que destaca el aporte que realiza Endara para desarrollar una nosología sobre el indígena. Considera al test de Rorschach "la base de un sistema caracterológico nuevo, que ha inspirado interesantes trabajos psicológicos" y dado que no requiere de "ilustración previa" sobre los individuos a los que se aplica, es un acierto de Endara haber recurrido a éste para realizar un "procedimiento de psicología profunda" en razón del "material humano que ha utilizado", o sea, indígenas incivilizados normales, cuyas "variaciones deficitarias" emotivas y de intelecto a diferencia de los blancos, "deben atribuirse necesariamente a sus condiciones de cultura, es decir, a factores ambientales." (Cueva, 1954, p. 122).

Al respecto de los logros obtenidos por el estudio de Endara, Cueva dice: "Y es alentador escuchar de labios de un auténtico científico, como lo es el Doctor Julio Endara, ideas optimistas sobre nuestros aborígenes, tanto más que no se trata de simples hipótesis o de una observación epidérmica de la realidad, sino de postulados que son fruto de dilatadas experiencias" $"$. Cueva comparte las conclusiones de Endara y su apuesta política por conducir la nación de la mano de la ciencia y por abordar con ella el "problema indigenista" y étnico del Ecuador. Para Cueva, la Patria debería estar en manos de los científicos poseedores de un saber capaz de llevar a cabo los objetivos de civilización del país. Para ello, además, es necesario de los gobernantes inspiren su gestión en la ciencia, y aún mejor, que esos hombres de ciencia gobiernen "para el bien de la patria y en redención de una gran porción de ecuatorianos sumidos en un persistente olvido secular” (Ibíd.).

\footnotetext{
${ }^{45}$ Lo mismo dirá ante un Congreso de Sociología en el que el problema de la raza en Ecuador es uno de sus ejes de reflexión: "Ha demostrado que, tanto la capacidad intelectual como la emotiva del indígena, presentaban las característica de una verdadera normalidad, siendo alentador escuchar de los labios de un autentico hombre de ciencia, como es el Dr. Endara, ideas optimistas sobre nuestros aborígenes, tanto más que no se trata de simples hipótesis o de observaciones epidérmicas de la realidad, sino postulados que son el fruto de dilatadas y difíciles experiencias." (Cueva, 1966, p. 142-3. En Landázuri, 2008, p. 211).
} 
Llama la atención que Cueva se refiera en este contexto de emoción y expectativa a las “observaciones epidérmicas" de la realidad, porque se muestra en oposición a ellas. Llama más la atención si se toma en cuenta que en 1953 un estudio titulado "La capital del Ecuador desde el punto de vista Médico-Quirúrgico" escrito por dos médicos franceses, Gayraud y Domec, publicado por primera vez en 1886, entra de nuevo en circulación gracias a que el Dr. Virgilio Paredes Borja ${ }^{46}$ encontró el original (que creía perdido) en la biblioteca de la Facultad de Medicina de París y lo tradujo. Gayraud y Domec fueron traídos desde Francia por el Presidente García Moreno en 1973 con el fin de que reformaran y modernizaran la medicina en Ecuador en lo que respecta a los estudios de Anatomía y Fisiología y técnicas quirúrgicas.

En su paso por el país, Gayraud y Domec, entre otras cosas, modificaron el plan de estudios, aumentaron el número de profesores de la Facultad de Medicina, separaron la Anatomía de la Cirugía y dieron más presencia a los estudios de Fisiología.

Entre sus reformas destaca su asesoramiento para la construcción del Anfiteatro Anatómico de la Universidad Central de Quito, el primero del país. En él se llevaron a cabo autopsias humanas con diferentes propósitos que sobrepasaban la formación práctica en medicina. Uno de los propósitos de las autopsias fue encontrar los rasgos anatómicos particulares de todos los grupos que conformaban la sociedad quiteña. Las conclusiones de las autopsias se complementaron con observaciones etnográficas realizadas por Gayraud y Domec sobre las costumbres de las poblaciones a las que estudiaron y que categorizaron en tres: Indios, Bancos y Mestizos.

En el prólogo que escribe el traductor, Dr. Paredes, no refuta ninguna de las tesis sostenidas en el libro. Por el contrario, las comparte, destaca la labor de estos médicos sin olvidar que ello no habría sido posible sin la gestión de un hombre tan visionario como García Moreno. Por lo que hemos visto respecto de la postura de los psiquiatras sobre la normalidad del indígena, se puede advertir que a pesar de compartir el mismo campo se visibilidad, los psiquiatras producen una narrativa sobre la verdad que reposa en el cuerpo del indígena distinta a la de Gayraud y Domec, revivida y compartida por el Dr. Paredes, una narrativa que disputa la verdad sobre el cuerpo del indígena, la identidad nacional y la identidad nosológica constitucional racial nacional y de clase de los distintos grupos que conforman la población en quito de mediados del siglo XX.

Este estudio, en inicio, fue escuela de la psiquiatría quiteña, según Osorio (2014) inaugura el punto de vista científico de la medicina, es expuesto como un estudio en parte "antropológico" de la cotidianidad y las condiciones en las que viven los quiteños, y en parte resultado de las autopsias a gente fallecida, entre ellos indígenas, como se advirtió

\footnotetext{
${ }^{46}$ Catedrático Principal de la Facultad de Medicina de Quito y Miembro Correspondiente de la Casa de la Cultura Ecuatoriana.
} 
anteriormente. Para Osorio este estudio es fundamento de una "protomirada higiénica", un momento de autopsia social y preocupación sobre la población como colectividad en el contexto de emergencia del punto de vista médico en el que el "mal" pasa a ser comprendido como patología que se ubica en el cuerpo. Esta mirada en la modernidad ecuatoriana actúa como "principio normalizador" - dice el autor- de la sociedad y los sujetos, como aspecto epistemológico del conocimiento científico médico: como principio de agrupación del discurso, unidad y origen de sus significaciones y foco de su coherencia.

Esta mirada médica moderna, según Osorio (2014) se dirige al menos a tres espacios: el cuerpo anatómico (el mundo de la patología el interior del organismo), biopolítica (organización espacial de la población así como costumbres y hábitos) y espacio clasificatorio (designación a sujetos y poblaciones en zonas de significación según el orden que ocupen en las categorías nosológicas), todo bajo el influjo positivista (p.55). La "protomirada higiénica", según este autor, alimentó la división de la población en razas: blancos, mestizos (cholos o zambos) e indios.

Aquí la existencia de los negros como alteridad étnica también merece caso omiso como en el estudio de Endara. Según los datos arrojados por ese estudio antropológico, blancos y mestizos vivían en condiciones higiénicas rescatables y los indios en cambio tenían hábitos defectuosos. Las conclusiones de las autopsias, que se enfocaron en el cerebro del indígena, desentrañaron unas facultades intelectivas inferiores en esta población. Se compara su cerebro con el de los antropoides y finalmente se concluye que "los indios tiene facultades intelectuales extremadamente reducidas, son incapaces de la menor iniciativa, no conocen otro móvil que el hambre, la sed o el miedo de un castigo." (Gayraud y Domec, 1953, p. 60-61).

Resulta interesante ver en la cita que se hace de Cueva y Endara como, más de sesenta años después, este discurso de la población dividida en razas, no solo es revivido gracias a la traducción del Dr. Paredes, también es re-inventado, pero en cierta medida intenta romper el supuesto respecto de la inferioridad intelectual del indígena. Cueva y Endara también hacen uso de la observación y del estudio antropológico (no de la autopsia), retoman del "principio normalizador moderno" el espacio clasificatorio y la biopolítica, pero a través de la teoría constitucionalista reinventan el cuerpo. Pasan de un cuerpo anatómico a un cuerpo somato psíquico para marcan un punto de quiebre sobre la perspectiva negativa del indígena, un cuerpo influido en su biología por el ambiente que actúa sobre la psique y por ende sobre las costumbres, los comportamientos, el intelecto, las emociones.

Sobre este cuerpo posan una mirada política que forma parte de un horizonte de expectativas ligado a la ventriloquía política indigenista, esta vez con el propósito de superar un pasado-presente-distante para traerlo por completo hasta la civilización. De la verdad anatómica que marca un destino sobre el indígena ubicándolo fuera del orden socio-biológico moderno, pasan a la verdad somato psíquica, y con ello generan un 


\section{desplazamiento epistemológico sustentado en la eugenesia-higiene que se traslada de una defensa de la herencia grabada de forma indeleble en los órganos a una defensa sobre el efecto de la cultura-ambiente sobre la psique y la biología.}

Ahora bien, recordemos que Cueva ya había hecho expresa su postura a favor de una psicobiología de la historia de la nación (Cap. 4). Ahora apuesta por la gestión científica de la Patria que unifique la "técnica científica" con las investigaciones sociológicas, al igual que Endara, aboga por la unidad de ciencia aunada a la sociología para la inteligibilidad del "problema indigenista", pues "para los fenómenos sociales el elemento básico es el hombre y el estudio biológico de él es el medio más seguro para tratar de mejorarlo" (Cueva, 1954, p.111). La colaboración entre ciencias es indispensable para el "progreso humano", para el avance de la "cultura moderna" y por ende de importancia para los problemas de la nación según Cueva, pues esta colaboración permite refutar desde el "indigenismo literario" local hasta las "generalidades" que se han formado sobre el indio desde la "ciencia extranjera" en base a criterios biológicos de "pureza de raza" y "herencia".

Para Cueva el estudio científico de las características biológicas del indígena permite obtener certezas sobre su degeneración o inferioridad, sobre sus "atributos valiosos para la vida en sociedad", sobre las "políticas indigenistas" estatales adecuadas y las posibilidades reales para su "incorporación a la vida civilizada". Dicha incorporación debe ir de la mano de la "Constitucionalogía", pues la somato-psicología contribuiría a elaborar las diferencias características somáticas y etnográficas del país, y para ello "la Biotipología puede conducirnos a formar un verdadero inventario étnico" con el cual se conocería al indígena y sus posibilidades de asimilación a la "cultura moderna" y ello equivaldría a "realizar la unidad nacional".

Cueva realiza un aporte a un antiguo deseo de su maestro. Desde muy temprano en el siglo, cuando era seguidor del darwinismo y el cientificismo de Ingenieros, Endara había lamentado que no se haga una tipología racial para fundar la nación tal como en la Argentina de tiempo de Ingenieros, una tipología racial nacional que "anticipe con optimismo" el futuro a través de una "Sociología" del Ecuador (Rodríguez, s/a, p. 7-8). Endara en aquel entonces solía atribuir a esta ausencia de tipología racial nacional la desvalorización de los talentos nuevos y patrios, ya que ello alimentaba la inclinación por la herencia española como ideario para la nación hispanista. En un contexto de reconfiguración del espacio simbólico de la nación avalado por el impulso instituido por la CCE de una modernidad cultural, la elaboración de un "inventario étnico" Biotipológico aparece de nuevo como coordenada anti-hispánica para la modernización definitiva del país y sus incivilizables.

Si para Endara el indo-hispanismo es una conciencia que se suma al indigenismo hispanoamericano en pos de la tradición cultural propia a través de la incorporación sin prejuicio biológico del indio a la nación moderna, para Cueva (1954) una lectura somato 
psíquica del indio le suma a la aspiración de Endara una apuesta por un concepto indoamericano de raza, que entienda los atributos del indígena desde un orden social y que reivindique "los derechos económicos y culturales de ciertas agrupaciones sociales, en oposición a otras agrupaciones, económica y políticamente más fuertes” (p. 113).

Cueva toma al biólogo y genetista Muller y al biólogo evolutivo humanista Julián Huxley para refutar la noción de supremacía genética de razas, basado en que estos científicos no han encontrado evidencia en favor a esa idea que antes que ciencia es una ideología nacionalista que "ha estorbado el progreso de la antropología" (Ibíd.). Discute las leyes de Mendel sobre la persistencia de caracteres somáticos hereditarios distintivos y específicos de las razas. Ante esta teoría antepone las tesis de la genética para plantear la dificultad que tiene, frente a la evidencia genética, atribuir caracteres específicos y mucho menos de pureza a la raza. "Podrá, en todo caso, hablarse apenas de determinado carácter somático, pero nunca por lo que se refiere todos o a la inmensa mayoría de caracteres de tipo hereditario" (Cueva, 1954, p. 114).

El problema de la civilización del indígena no se da por caracteres heredados, para defender esto se debía sostener, como lo hace cierta "Antropología raciológica" a la que se opone Cueva, que hay una pureza negativa o positiva que se hereda, lo que es para él insostenible desde el punto de vista cromosómico y genético. Es infecundo clasificar a los "grupos homogéneos en sentido somático", porque las características endocrinas (como el hipotiroidismo o hiposuprarrenalismo) no son caracteres raciales, "deben ser tomados como accidentes; no son estados constitucionales ni hereditarios y hay que referirlos en último término, a su género de vida" (Ibíd.). Hace falta, entonces, un criterio biotipológico que de cuenta de la cultura, entendida esta como ambiente y ponga en consideración los caracteres somáticos, morfológicos, fisiológicos y psicológicos. Poner en perspectiva el ambiente significa para Cueva poner en perspectiva lo social, para entender, por ejemplo, como el cruce entre razas ha favorecido cierta escalada social que da lugar a escenas como las de "un hijo de peón que se asimila a la cultura de los blancos, adquiere una nueva posición social y por defensa de clase se aparta de su primitivo estado por el vestido, el lenguaje, las costumbres, etc., y adquiere una poderosa tendencia niveladora que borra el espectro de la raza en su sentido social" (Ibíd.).

Esto que pareciera una contradicción en Cueva, más bien forma parte de la coherencia de la voluntad de acción de la eugenesia en la que encontramos cientificismo como vía de mejora del hombre, conducción científica de la vida nacional, clasificación científica étnica como oportunidad de unidad nacional y superación de un estado pre-científico respecto de la lectura antropológico raciológica del indígena y de la nación.

No es que Cueva vea en la escalada social una forma de aliento de una cruza deseable de razas, apuesta más bien por la adopción de costumbres, lenguaje, vestido: una forma de vida en la que un estado primitivo se civiliza al asimilarse a otro ambiente. Se trata de una 
voluntad de acción eugenésica que, como vimos, se ha ensayado en otros países del continente: un mestizaje civilizador, esta vez, no por cruzamiento de razas, sino por asimilación de cualidades positivas que conforman el ambiente. Ello es posible para Cueva a través de la definición somato psíquica del indio para la adecuada conducción y traslado científico de éste y de todo sujeto en "estado primitivo" hacia la incorporación de los valores y costumbres del tiempo moderno.

\subsubsection{El criterio biotipológico del indio somato psíquico y la cronotopía regulatoria}

En el principio normalizador moderno en el que la voluntad de acción psiquiátrica construye una ventriloquía política indigenista sustentada en la eugenesia ambientalista, que en este caso pasa del cuerpo orgánico al énfasis en la verdad somato psíquica, se realizan dos operaciones: una representación de tiempo (en la que el indio somato psíquico, pese a ser un presente atávico, desplaza la fatalidad del destino al que el indígena fue sumergido en la verdad del cuerpo orgánico y pasa a ocupar un cuerpo y una psique normal en el que se inscribe un destino teleológico nacional) y una ampliación del campo de visibilidad y el horizonte de expectativas (en el que la biotipología es el criterio teórico de la inteligibilidad de la heterogeneidad racial de la nación).

Para Cueva el aporte que la biotipología le puede proporcionar a la sociología proviene de su exactitud científica, que a su vez se nutre de otras ciencias modernas como la psicología, antropología, biología, endocrinología, psiquiatría, matemáticas, medicina, etc. Para la biotipología los seres humanos pueden ser agrupados por sus caracteres somáticos y psíquicos tras someter a los individuos a pruebas que determinen las condiciones físicas y mentales de los individuos, y -aclara Cueva- aunque no expliquen por sí solos los fenómenos sociales, la sociología debe integrarlos junto con aportaciones científicas de toda índole. La definición de los biotipos para el estudio de las razas es de tal alcance que además de establecer el biotipo predominante de cada raza y las "variedades y disparidades entre un mismo biotipo de distintos grupos étnicos", para Cueva también se puede establecer el biotipo que predomina en cada clase social.

Cueva entabla un diálogo con los representantes de distintas escuelas biotipológicas: Rostand y el principio de predominancia de acción de un sistema sobre otro, De Giovanni y la teoría del biotipo como desviaciones "en relación a la combinación ideal abstracta", Stiller y la distinción entre constitución asténica y esténica, Viola y la constitución como las "variaciones cuantitativas individuales de los caracteres antropométricos", Pende que agrega al biotipo de Viola características fisiológicas, neuroendócrinas y psíquicas, y finalmente, la escuela tipológica alemana con Jaensch y sobre todo Kretschmer quien descubrió "tres estructuras fundamentales del cuerpo: el asténico, el atlético y el pícnico. En la discriminación de las estructuras corporales, Kretschmer se basa, en primer término, en el examen visual de los sujetos y, después, en un examen antropométrico" (p.117). Es en 
este modelo principalmente en el que Cueva se basa para establecer el biotipo indígena como un conjunto de cuatro tipos:

\section{Tipo somático}

Desde un punto de vista sintético y de simple observación de los grupos indígenas, [puede hacerse] el inventario de sus características somáticas de la siguiente manera: estatura baja hipomesosomia-, macrosplánico o brevilíneo; cara alargada o cuadricular, (...) abdomen voluminoso y abombado -acaso por la exclusividad vegetariana de su alimentación-; miembros superiores generalmente largos y musculosos; manos fuertes, muñeca ancha, miembros inferiores más cortos y de musculatura robusta. Acaso -como ya tuve ocasión de hacerlo notar [en el] Congreso Indigenista en Pátzcuaro, México- más específicamente el indio encaja dentro del tipo atlético, por tener, además de las características somáticas de este tipo, una forma temperamental propio y específica que, con Kretschmer podría llamar $\operatorname{viscoso}^{47}$, aludiendo a su torpidez y tendencia a la estabilidad, características del indígena.

\section{Tipo fisiológico}

Los principales tipos fisiológicos $-\mathrm{y}$ que se derivan de los estudios de Eppinger y Hescorresponden a las llamadas constituciones fisiológicas antagónicas: vagotónico y simpaticotónicas. [No se ha realizado estudios de laboratorio del sistema órgano-vegetativo, pero sí con] métodos al alcance del médico general. Con estas exploraciones se podría concluir que el tipo fisiológico del indio es vagotónico, con sus manifestaciones características tales como: lentitud del ritmo cardiaco, baja tensión arterial, depresión psíquica y ligera hipotermia.

\section{Tipo endócrino}

De manera esquemática puede asegurarse que el funcionamiento de las glándulas de secreción interna tienen acción indudable sobre la constitución somática. (...) dadas las condiciones que prevalecen entre nosotros, podremos determinar las constituciones endócrinas y apreciar la forma general de la morfología, fijándonos en la talla, en el desarrollo muscular, en el desarrollo de los órganos sexuales, en la distribución de la grasa, en el metal de voz, en el matiz de la piel. (...) Entre los distintos tipos establecidos por Pende para determinar el tipo endócrino, se podría decir que el indio entra en la variedad del brevilíneo-asténico, naturalmente con las limitaciones naturales desde el punto de vista colectivo, ya que todos no han de corresponder a una variedad o tipo puro, sino más bien a un cuadro mixto. Las características de este tipo son (...) el hipotiroidismo, hipoparatiroidismo, el hipopituitarismo y el hiposuprarrenalismo (...) Características fundamentales y somáticas del hipotiroidismo en el indígena, serían: su tipo matomegalosplácnico (...). Fisiológicamente: la vagotonía, la bradicardia, la bradipsiquia, la apatía. En la esfera psíquica sabemos que los hechos indiscutibles que establecen la conexión entre la acción nerviosa y las acciones humorales, son, en primer término, la influencia indudable que la fusión tiroidea ejerce sobre la vida psíquica. Por eso, el hipotiroidismo del indígena es causa de la torpidez mental, de la indiferencia afectiva y de la apatía intelectual, tan claramente definidas en él, pero tan superficialmente estudiadas en su

\footnotetext{
${ }^{47}$ Que son persistentes y poco flexibles, de escasa imaginación, callados y estables afectivamente.
} 
verdadera proporción causal. La descripción del temperamento indígena, siguiendo esta dirección, tendría su correspondencia con la afectividad sencilla y univoca y su posición fatalista y resignada ante la vida, como constituyente de los rasgos característicos del tipo cicloide, correspondiente a su variedad morfológica y constitucional.

Tipo mental

Aquí Cueva retoma las conclusiones a las que llega Endara sobre la normalidad del indígena, una normalidad que inclusos en sus variaciones deficitarias se encuentran dentro de variaciones normales, salvables. Y hace énfasis, como vimos, en que las aportaciones científicas al problema indigenista son de suma importancia para su incorporación definitiva en la vida civilizada, y en que de la lenta "acción metódica" deben salir las inspiraciones normativas para la gestión gubernativa de la patria y la redención de los grupos perjudicados por lo que Cueva llama "olvido secular".

Con Endara encontramos a un indígena psíquico en oposición a un indígena anatómico. En las características psíquicas encontramos un "ligero debilitamiento de la capacidad abstractiva", "ligero matiz depresivo", introversión, "ligero defecto de madurez del equilibrio interno", "cierta constricción" en las "interpretaciones de forma", menos potencial para el razonamiento, aptitud para la conquista intelectual, "pero menor capacidad productiva": todo dentro de los límites de la normalidad. En Cueva ahora encontramos una biotipología, un indígena somato psíquico, una caracterización más completa, también normal: un cuerpo atlético, vagotónico, brevilineo-asténico, hipotiroidismo. Aunado a este cuerpo encontramos una psique con indiferencia afectiva, torpidez mental, apatía intelectual, afectividad sencilla y unívoca, fatalista resignado cicloide.

Pareciera que en ciertos aspectos entra en contradicción con Endara, pero no, pues toda deficiencia somato psíquica puede ser médicamente tratada. Lo importante es saber sobre qué psique y sobre qué cuerpo ejercer la voluntad de acción psiquiátrica para su mejora eugenésica. Es importante saber qué cuerpo y qué mente serán trasladados de un ambiente a otro. Es esa la importancia de establecer una biotipología de las razas en la nación: saber cuan posiblemente normales y normalizables son los individuos, poseer un saber exacto del biotipo que será incorporado, poseer un sistema de verificación para saber qué cuerpos y qué psiques serán científicamente conducidos y geo-temporalmente condicionados en su tránsito a la modernidad.

En Cueva la biotipología se organiza como un modelo teórico de "explicación-producción" (Polo, 2010) en el que se establece un "dialogo con lo real” racial nacional. La biotipología es un "concepto-hecho" (Koselleck, 2009) con el que Cueva piensa determinar "los elementos constitutivos de la raza" y con ello comprender por un lado la realidad histórica (como habíamos visto), y por otro la realidad racial, y proyectar así el telos-destino biológico-histórico-racial del indígena y la nación ecuatoriana. La voluntad de acción 
psiquiátrica se canaliza en la biotipología pues, como dice Koselleck, el concepto-hecho organiza el diálogo con lo real, pero también permite efectuar acciones concretas sobre lo real en la medida que inyecta significaciones sobre lo real, que en este caso son significaciones sobre lo normal civilizable.

Ya no se trataría para Cueva y Endara solo de civilizar a través de la educación como el higienismo (Kingman, 2008) lo sugirió al igual que varios indigenismo que encontraron en la educación una forma de distinción social, una vía para el progreso, un criterio naturalizador de la jerarquía social, una forma de ascenso social, una forma de representación del retraso (de la Cadena, 1997, p. 28), una forma de incorporación del indio a la nación y de incorporación de los símbolos nacionales en el indio, o una forma de modernización del indio (Prieto, 2010, p. 255).

Para Cueva, esa educación y la modernidad misma es un despropósito sin la guía científica. Se trata de tener un conocimiento social, histórico y científico de la nación. El inventario étnico de Cueva permite no actuar de forma improvisada en la incorporación de los indígenas y las distintas etnias. Antes de incorporar hay que realizar una investigación previa para determinar las razones de su incivilidad y determinar con ello sus capacidades reales de inserción sabiendo qué cuerpo y qué psique será la que se incorpora a la nación moderna. Sin un conocimiento científico previo de las características biológicas dimensionadas en lo social e histórico para evaluar, como dice Cueva, "los atributos valiosos para la vida en sociedad" la incorporación no tendrá resultados. Pues para Cueva y Endara la incorporación a la civilización es un traslado de una psique y un cuerpo de un ambiente a otro. Una vez que se realiza un "inventario étnico" y una caracterización biotipológica de los "elementos constitutivos de la raza" se puede proceder al traslado científicamente guiado de un individuo somato psíquico de un ambiente a otro, de una cultura a otra. La normalidad del indígena es la garantía de que podrá ser civilizado e incorporado en otro ambiente.

Es entonces que la biotipología además de ampliar la visibilidad y el horizonte de expectativas psiquiátrico, construye una posibilidad futura para la ciudadanización y la civilización del indígena, una posibilidad en la que la teleología nacional se implica en los criterios de construcción de lo normal de un presente atávico y lo condiciona como lo normal por venir, pues en Cueva la coetaneidad del indígena aún es negada y éste en la biotipología es aún un "objeto alocrono" (Díaz, 2014, p. 3): negado en la identidad del nosotros modernos ciudadanos de la nación ecuatoriana, el indígena es representado por la biotipología en una relación social de tiempos en el que es apartado fuera de la experiencia social del tiempo moderno, representado fuera del "tiempo comunicativo" (Ibíd.) de la nación. Sin embargo, el hallazgo científico de su normalidad somato psíquica le augura un lugar en la modernidad nacional (futura). Denominaré a esta representación de tiempo como cronotopía regulatoria: negación de la coetaneidad, expulsión de la experiencia 
social del tiempo presente de sujetos discordes a los ideales del telos-destino de la nación moderna, condicionamiento del devenir para ocupar a futuro un lugar social legítimo y aceptado dentro de la narrativa otrificadora-psicobiológica de la imaginería nacional y concepto-hecho para organizar un diálogo con lo real, otorgar significaciones a lo real, constituir el hecho histórico y como fuente para la constitución de los objetos de saber psiquiátricos.

En Cueva y Endara es el concepto de normalidad el que se impone para ser un ciudadano moderno de la nación. El indígena civilizable, el indígena somato psíquico, es una especie de conector somático y psíquico de los ideales de la nación, es un cuerpo normalizado en el ideal nacional. El indio normal, el indio somato psíquico, en esta ventriloquía psiquiátrica que conjuga eugenesia ambientalista e indigenismo, es un cuerpo portador de ideales regulatorios para la modernidad ecuatoriana, es un virtual constructor de ecuatorianidad. Es el cuerpo en el que se proyecta el tiempo de la pedagogía de la nación. El indígena somato psíquico como representación de tiempo, es la contención de la heterogeneidad corporal, cultural, política, histórica del indígena, es la contención de la heterotopía en la medida en que es una cronotopía regulatoria: el indio somato psíquico es una cronotopía regulatoria homologadora que dibuja en el futuro nacional una normalidad psíquica y somática, proyecta un cuerpo y una subjetividad posible para el indígena... un indígena posible, un indígena admitido o por admitir. El indígena somato psíquico es una cronotopía regulatoria porque en éste se materializa la imaginación política de la nación moderna.

\subsection{3 "Psicología del padecer” de la nación como concepción nativa del tiempo}

El Dr. Enrique Garcés publica en 1953, en los Archivos de Criminología, un trabajo titulado "Necesidad de una Psicología del padecer de los pueblos". En este trabajo, Garcés introduce la categoría "padecer" como un componente teórico para la comprensión de la estructura psíquica de un pueblo, y desde allí abordar el pasado y comprender su desarrollo histórico, político, económico, cultural a través de una "Psicología de la Historia" o incluso un "Psicoanálisis de la Historia".

En este ensayo la psicobiología se perfila como un modelo de producción de historia a través de la interpretación psicológica y psicoanalítica de la psique y su evolución en la histórica del 'nosotros', de composición de escenas narrativas para la historia de la nación y para la construcción de la ecuatorianidad como identidad nacional, de establecimiento de cronologías como un programa ético y urgente de estudio de la historia ecuatoriana dividida en épocas, y como modelo preventivo-profiláctico para la superación de conflictos psíquicos que no permiten el avance de un pueblo en sus búsquedas políticas, identitarias, sociales, económicas, etc. Garcés postula el "padecer" como categoría para la producción de sentido sobre las temporalidades de la nación. 
El padecer, según Garcés (1953), es una condición de la vida individual y de la vida colectiva, la vive desde un individuo hasta un pueblo. Es el "resultado de la tremenda necesidad de adaptarse al medio y al tiempo", es una mezcla de dolor (lo fisiológico) y pena (lo intelectual) que afecta "como es lógico al sistema nervioso". El padecer implica todas las características de sensaciones y sentimientos dolorosos y penosos, de modo que si se realiza una 'psicología de los pueblos, será preciso referirse al 'padecer' de los mismos. (...) La vida de los pueblos es ante todo 'padecer' en la formidable y fragorosa historia de su devenir" (p. 193-194).

En un continente tan joven como América que aún continúa con su adaptación al medio y al tiempo, dice Garcés, el padecer es de suma importancia para comprender su historia. Indagar en la psicología de los pueblos desde esta concepción aporta a la historia una comprensión acerca de lo que los pueblos hicieron con el dolor y la pena, y lo que el dolor y la pena hizo con los pueblos: si la "carga energética psicológica" del padecer sobre el sistema nervioso los condujo hacia el triunfo o la derrota.

Después de meditar largamente acerca de cuántas cosas parece que se han quedado sin explicación en el pasado, creemos que es necesario y urgente una Psicología de la Historia, quizá más: el Psicoanálisis de la Historia. Porque francamente, qué se puede entender de una suma de hechos y sucesos, así estén acompañados hasta de Filosofía de la Historia, si se guarda silencio (...) sobre las motivaciones psicológicas de los pueblos? (...) Y luego, cómo ha de ser posible que de una Psicología de la Historia bien dirigida, no se obtengan directrices evidentes para que los pueblos sepan precisamente utilizar sus padecimientos hacia el triunfo, evitando -en verdadera profiaxis, demofilaxis mejor- el atajo de la derrota?. (Garcés, 1953, p.195)

No se puede ni se debería, para Garcés, escribir la historia de los pueblos sin saber cómo las fortunas o desventuras "corresponden a reacciones psicológicas". No solo porque el padecer como categoría histórica permite comprender mejor el pasado, sino porque permite prevenir, proteger y preservar el devenir de los pueblos: a la vez que es una categoría histórica es también su motor, su productora, y en esa medida saber si el padecer, en nuestra adaptación al medio y al tiempo, nos ha conducido a la derrota o al triunfo, nos permite comprender un aspecto profundo de nuestra psique colectiva y con ello prevenir el porvenir. De allí que este autor vea en la Psicología de la Historia la oportunidad de una profilaxis, o mejor aún de una demofilaxis, una medida de preservación-protección del pueblo (¿especie?), para que éste sepa qué hacer y cómo utilizar sus padecimientos en beneficio de sus proyectos.

Sin el estudio psicológico de la historia a través de la categoría del padecer el Ecuador adolece de un extravío y un desconocimiento de sí mismo. Siguiendo el ejemplo de "los grandes maestros de la psicología profunda" (como Freud y Jung) establece una cronología que se remite a las "etapas salvajes en el hombre civilizado" para realizar una investigación de la "inteligencia arcaica" a fin de establecer los nexos entre psique, magia y mito -entre 
psique y pasado-. A causa de lo poco que conoce el país sobre esta área, la "gran masa india, irredenta, empobrecida" que habita en el país, es la portadora del rastro para el "descubrimiento de esos datos esenciales" que permitirían hallar en la historia prehispánica "nuestro psicoesquema colectivo". El siguiente periodo trataría de la interpretación de la integración de las Tribus que integraron la Confederación del Reino de Quito en donde la superposición de culturas que allí aconteció es propicia para indagar sobre el padecer que cada cultura sufrió. Finalmente, las dos siguientes etapas son la Colonia y la República "suma de grandes padeceres y siembra de inquietantes actitudes. La Independencia que no puede ser otra manifestación que el grito insumiso de los indios al que se sumó la protesta del mismo español transformado por el medio, requiere de más justas apreciaciones desde el campo de la psicología del padecer" (p. 197). Precisamente, este periodo requiere indagación porque la adherencia española a la rebelión de los indios se da porque la psique del español fue transformada por el medio, y para el modelo somato psíquico que se está configurando, la influencia del medio sobre el genotipo es de sumo interés.

La psicología de la historia se remite al pasado remoto con el fin de realizar una psicología profunda de la psique ecuatoriana. Buscar en el pasado para traer al presente el recuerdo y unas explicaciones de carácter psíquico provenientes de ese pasado, y con ello tener una mirada más completa del psicoesquema colectivo ${ }^{48}$ que no desafía las cronologías legítimas de la historia, pero si les disputa sentidos al manifestar que la historia no puede ser contada como una sucesión de hechos, sino que los hechos han sido motivados por la psique y siguen siendo motivados trazando el rumbo de la historia de un país, y además, en las motivaciones psíquicas de esos hechos está la clave de la identidad del pueblo. El padecer es la concepción nativa del tiempo con la que Garcés define la

\footnotetext{
${ }^{48}$ Es este un esquema que conjuga psicoanálisis, lamarkismo y darwinismo, en la medida que propone que la realidad psíquica conjuga contenido inconsciente, adaptación al medio y caracteres adquiridos, Freud, Darwin y Lamark. Estas corrientes a criterio de Eduardo Balbo Ambrosolio (2002) no son tan distantes puesto que el evolucionismo en la psiquiatría clínica ofreció un marco teórico potente para explicar la etiología de conductas y estructuras sociales. "El propósito de entender desde un punto de vista evolucionista aspectos etiológicos de las enfermedades mentales (neurosis y psicosis) se encuentra [en la] obra de Sigmund Freud. (...) Freud teoriza que las conductas patológicas son vestigios de una conducta adaptativa desarrollada en una historia evolucionista. La hipótesis de un alma colectiva y de un criterio evolutivo hereditario lo hallamos en [Tótem y tabú cuando Freud] nos habla de 'que la conciencia de culpabilidad, emana de un acto determinado (se refiere al incesto), ha persistido a través de milenios enteros, conservando toda su eficacia en generaciones que nada podían saber de dicho acto'. También el concebir el funcionamiento psíquico en términos de tendencias (pulsiones, instintos) y energía (líbido) significa considerarlo en una perspectiva genético evolutivo: las tendencias, parciales al momento de nacer, se fusionan y van madurando posteriormente. Son procesos dinámicos que se ubican entre lo biológico y lo psicológico. Las teorías freudianas y las de Carl G. Jung se atienen a la doctrina de Haeckel donde la ontogenia recapitula la filogenia.” (p. 48). En cuanto a Lamarck, podemos notar una preocupación de Garcés, Endara y Cueva por la transmisión y el ambiente y por la capacidad de adaptación del indígena a otro ambiente como un problema somato psíquico, encontramos aquí a Lamarck y Darwin en la medida en que la primera teoría al referirse a la herencia de los caracteres adquiridos plantea que "los seres vivos reciben de su medio, de la repetición de ciertos actos, unas informaciones que se transforman en hereditarias y, por tanto, se transmiten de generación en generación. De acuerdo con este enfoque lamarquiano de la herencia, la memoria genética, al igual que la memoria mental, funciona mediante el aprendizaje. [Por el lado de la teoría de la evolución, ésta] nos da un criterio para distinguir lo normal de lo patológico, y el criterio es el de la adaptación o desadaptación biológica y lo que vendría a subrayar el enfoque evolucionista es dar prioridad al grado de adaptación social" (p. 54-55).
} 
Ecuatorianidad como una vivencia, una emoción que debe incorporarse al hombre ecuatoriano. Y para la forja de ello, necesitamos el análisis de los resultados del padecer de los pueblos en las diferentes épocas de nuestra historia y singularmente en la que se refiere a la historia prehispánica de la Patria. Creemos, con toda fé y potencia, que los ecuatorianos no actuamos con sinceridad [porque] Desconocemos nuestra psicología nacional. Y sobre todo aquella parte de la psicología de padecer que tanta influencia tiene en los destinos de la colectividad. (...) Cómo podemos ser sinceros, si apenas sabemos algo de parte de nuestra formación de pueblo y eso también en lo que se refiere al aporte español de la conquista que fué dura, inicua, que venció a la otra parte que llevamos dentro de la sangre y de la psique y que corresponde a lo indio?. (p. 197)

Por ello importa el indio y la época prehispánica en la historia ecuatoriana según Garcés, porque esa historia la lleva todo el pueblo en su sangre y en su psique nacional, en su sistema nervioso, en su cuerpo: en su genética. Cuando Garcés habla de sangre no alude al discurso sobre la sangre en el sistema de castas de la colonia que vimos con Varena Stolcke (2000), alude a un problema genético, que al igual que Cueva le parece una verdad indiscutible. Cuando habla de sangre y psique, se refiere a la expresión de un genotipo en los fenotipos y biotipos de la nación, y a la vez ese pasado inscrito en la sangre se expresa en la psique, como el inconsciente y el preconsciente en el Yo, como el padecer del pasado en el padecer del presente.

Por ello es tan importante para estos médicos y psiquiatras la investigación psicológica, constitucional y hasta psicoanalítica del "sujeto aislado (...) para tener conclusiones ciertas sobre su biotipo y su psicoesquema. De otro modo, lo que se haga alrededor de ese pueblo, tendrá demasiado empirismo y demasiada insinceridad." (p.198). Sobre ello parece haber un acuerdo bastante extendido y las investigaciones constitucionales forman parte ya de la práctica psiquiátrica, médica y jurídica, forman parte del aparato mismo del Estado. Por ejemplo, cuando el Dr. José Cruz Cueva (1953) se presenta como perito designado para examinar a la presunta insana Victoria Vela de Paredes por un caso de contrato de compraventa y determinar su estado mental y capacidad civil, elabora un informe médico legal sobre el estado psíquico de la presunta, Cruz muestra un estudio clínico somato psíquico estructurado en Antecedentes hereditarios, Antecedentes personales, Examen somático (en el que se determina desde Kretschmer su estructura corporal leptosomática), Examen psiquiátrico, Diagnóstico, informe pericial, Comentarios y Conclusiones.

Así mismo, en sus estudios sobre "Degradaciones y Desvitalizaciones en los delincuentes a través del test de Rorschach", Julio Endara (1959) manifiesta la necesidad de un conocimiento profundo de la psique de los individuos, a razón de que este puede ayudar a identificar desde la criminogenia (comportamiento criminal) hasta los mecanismos psíquicos "que funcionan en el curso de la experiencia humana pero que tiene singular importancia en las etapas de formación: las identificaciones y las relaciones de objetos tan esenciales para la formación de la personalidad" (p. 171). Lo que importa para Endara es que el Rorschach al ser un test proyectivo "no muestra reflejos de las percepciones del 
sujeto" sino algo mucho más profundo: la estructura psicológica del sujeto, los contenidos conscientes e inconscientes que requieren interpretación psicoanalítica. Muestra la "imagen psíquica" (identificaciones, relaciones de objetos, estado de socialización y la capacidad de captación consciente y de autoconciencia). Es decir, según Endara, el test no muestra el contenido de un reflejo de lo que "se ve alrededor", sino más bien los "símbolos de lo que se ha introyectado e incorporado, a los cuales se identifica y los cuales se asimila" (p. 171172). Muestra la "experiencia vivida", que es a lo que se quiere llegar en aras de un conocimiento de la psicología individual y de la psicología nacional ${ }^{49}$.

Por supuesto el conocimiento estadístico como parte del proceso modernizador y la legitimación de la autoridad científica atraviesa la práctica médico-higiénica (Kingman, 2008), y es parte del campo de visibilidad psiquiátrico y su horizonte de expectativas en este modelo somato clínico de interpretación-conducción de la historia y construcción de la identidad nacional. Así lo muestra Endara en un "Proyecto de ley de Salud Mental". A través de la estadística, el Ecuador se puede poner a la par de los países civilizados en cuanto al conocimiento de la morbilidad del país, y sobre todo porque podría determinar las "variantes debidas a las influencias culturales y mesológicas en cada caso. [Para el Ecuador] tiene un valor de importancia capital, pues los componentes étnicos y culturales de las distintas regiones de nuestro territorio seguramente tiene modalidades propias que deben ser minuciosamente conocidas y apreciadas para adaptar a ellas la orientación de los tratamientos" (Endara, 1962, p. 226).

Entonces, la ampliación de expectativas para la psiquiatría que ofrece el modelo somato psíquico, permite que la palabra-concepto-hecho (Koselleck, 2009) sea parte incluso de procedimientos jurídicos y, a través de ésta se determine qué cuerpos y qué psiques están aptos para la ciudadanía conforme a su normalidad o anormalidad somato psíquica. Encontramos aquí al cuerpo psíquico en la antesala del control político, como conector somato-psíquico de los ideales de la nación, como representación de tiempo, como regularidad para la aprehensión de objetos de saber psiquiátrico, como modelo de interpretación histórica, como vía civilizatoria. Lo que es al tiempo del cuerpo somato-

\footnotetext{
${ }^{49}$ El lugar del psicoanálisis en la historia del Ecuador es un tema por investigar. Me gustaría apuntar que la opinión que le merece Freud a los médicos y psiquiatras de la serranía principalmente, al parecer no es compartida por la psiquiatría y la medicina guayaquileña. Si ello tiene relación con que las élites económicas e intelectuales de la Sierra y la Costa desde la independencia se disputan los sentidos simbólicos que aglutinan al Ecuador como nación, no lo sabemos. Pero si podemos suponer que, en relación al psicoanálisis, al interior del campo médico y psiquiátrico hubo una disputa por la regularidad y las reglas de aprehensión de los objetos de saber con los que establecen diálogos con lo real y con los que establecen sentidos con los que construyen lo real. Por ejemplo, en el mismo número de los Archivos de Criminología en que se publica el Proyecto de Ley Salud Mental propuesto por Julio Endara, se publica también el contenido de una exposición del Dr. guayaquileño Fortunato Safadi en el V Congreso Médico Nacional y I de Neuro Psiquiatría en torno a la "Organización de la Higiene Mental en el Ecuador". En este texto Safadi promulga la organización de la Salud Mental en el país desde una fuerte inclinación hacia la higiene profiláctica y preventiva con una marcada orientación eugenésica que, aboga por evitar la aparición de la enfermedad mental interviniendo (educando) psiquiátricamente al niño. Para ello, el psicoanálisis debe estar ausente si no se le quiere restar potencia y seriedad al propósito. Dado que para Safadi el psicoanálisis no es siquiera una teoría, éste no tiene nada que ofrecer en cuanto a un saber científico y preventivo sobre el niño en el Ecuador.
} 
psíquico es al tiempo de la nación: la forma de abordar una realidad somato psíquica es la forma de establecer cronotopías: líneas de tiempo, cronologías con las cuales organizar las experiencias dolorosas y penosas del pasado de un pueblo, y es el saber científico que se requiere para la conducción de la normalidad por las vías de la civilización y la modernidad.

\subsubsection{El indígena mítico en los Archivos de Criminología: temporalización de lo normal y producción del pasado}

\subsubsection{El ambiente y la patología como causa del retraso del indígena}

La patología como objeto de saber de la medicina moderna en el Ecuador (Osorio, 2014) permitió advertir en la tuberculosis, la sífilis y el alcoholismo tres preocupaciones médicas para la salud colectiva del país (Rodas, 2011; Serrano, 2016) que condujeron a una corriente médico-social biopolítica higienista a establecer criterios científicos y técnicos para la orientación del crecimiento de la Urbe y la población ligada a las prácticas estatales de salubridad, seguridad social, a la cátedra y la investigación universitaria (Kingman, 2008). La higiene en el siglo XX se perfila como una tecnología para la vigilancia y la generación de comportamientos, costumbres, hábitos de higiene y normas de comportamiento: construcción de patrones civilizatorios y preventivos (Ibíd.). Estas prácticas médicas biopolíticas de higiene formaron parte de las actividades académicas y de investigación en los Archivos de Criminología así como de los programas internacionales a los que se suman y de los que forman parte los psiquiatras de la serranía ecuatoriana.

En el Acta Final del "Tercer Congreso Latino-Americano de Salud Mental” de 1958 se resuelve recomendar a los Gobiernos de los Estados de América Latina "Condenar la toxicomanía" a través de normar y sancionar la coca y otras drogas como el mescal, apuntia, yage, ayahuasca etc., asociadas ellas a un consumo indígena (p. 604). Por ello, educar al indígena mal portado normando las labores agrícolas y modificando sus costumbres será parte de la solución higienista-eugenésica en su expresión psiquiátrica, que ve en el consumo de ciertas bebidas y sustancias un comportamiento patológico. Este llamado a los gobiernos por parte de los psiquiatras Latino Americanos abocados a la construcción de la Salud Mental de los Estados, aparece como una "condena" a lo que la eugenesia en Perú comprendía como el "mal uso del cuerpo" (Yzú Rossini, 2016, p. 31-57), en la medida en que -dice esta autora- la toxicomanía deteriora los propósitos nacionales políticos, sociales y económicos, y obstaculizan el mejoramiento eugenésico de la raza.

Combatir el alcoholismo como "un mal uso del cuerpo", sería parte de un programa político y social que la psiquiatría se traza y que cada país resuelve como puede. A pesar de que esta noción del "mal uso del cuerpo" puede ser heredera de la visión del "indígena como 
arquetipo negativo ${ }^{50 "}$ (Espinoza, 2003) no responde a ella por completo. La diferencia radica en que ahora los criterios científicos psiquiátricos no consideran que la patología sea específica del indígena ni de su organismo, no se puede atribuir a ello, sino a la cultura (ambiente). Si no le es intrínseco, no hereda una condición y más bien la adquiere. Por tanto la negatividad del arquetipo puede ser modificada y conducida científicamente, pues la normalidad psiquiátrica del indio muestra una psique y un cuerpo capaz de adquirir y portar los signos de la modernidad.

Patricio Canelos S. y Rodney Cevallos T., realizan una investigación de campo en una Comunidad Indígena de Llano Grande, ubicado en las periferias de Quito. Los resultados de su investigación son plasmados su Tesis Doctoral publicada en los Archivos de Criminología en 1967 con el título "Manifestaciones Psicológicas y Psiquiátricas del alcoholismo crónico en la población indígena”. La tesis fue dirigida por el Dr. Julio Endara. En este trabajo, el cuerpo indígena intoxicado de alcohol, aparece como un cuerpo improductivo y patológico a causa de la ingesta crónica de alcohol que deriva en unas manifestaciones psicológicas y psiquiátricas que constituyen un cuadro patológico que trae al país "repercusiones psicológicas, sociológicas, económicas (...) Problema bastante serio, bajo su importancia universal es muy conocida. Adquiere ribetes alarmantes en nuestra vida sociedad y precisando más los términos, en nuestros indígenas es causa innegable de su retraso general" (Canelos y Cevallos, 1967, p. 92-93).

En el trabajo de Canelos y Cevallos el cuerpo del indígena alcohólico se encuentra repleto de patología, no porque el cuadro patológico sea intrínseco a la biología del indígena (eso como vimos, ya ha cambiado), sino por los efectos del consumo alcohólico.

El desencadenante de la patología, según la investigación proviene del ambiente: de las costumbre, de las creencias, comportamiento, la falta de educación, de mitos, religiosidad, etc. En el estudio ambiental que realizan estos médicos en la Comunidad Indígena de Llano Grande, el indígena es descrito como un agrícola rudimentario bastante ignorante en el tema de la labor sobre la tierra así como de la artesanía, con actividades económicas de comercio, a no ser que sean protestantes son poco ahorradores y gastan todo el dinero que han reunido con esfuerzo si son elegidos padrinos de alguna actividad. Sus creencias son calificadas como arcaicas, cree que toda fuente de felicidad está fuera de ellos y profesa una religiosidad de la que poco o nada entiende. Es de carácter psico-estable. No tiene nivel de instrucción superior. Es tímido y con un notorio complejo de inferioridad. Es machista. Canelos y Cevallos advierten que el indígena, con grado de consumo no patológico, no es

\footnotetext{
${ }^{50} \mathrm{El}$ "indígena como arquetipo negativo", una tesis que Espinoza toma de Carlos Arcos, es un "fenómeno que surgió como parte del proceso de modernización agraria en la Sierra a finales del s. XIX e inicios del s. XX. En efecto, la apología del progreso técnico llevada a cabo por los hacendados modernizantes creó una imagen tal del indio, que éste se convirtió en un sinónimo de perversión y estupidez; de vagancia y estulticia, a quien debía transformárselo a la medida de las necesidades de la modernidad. El indio fue presentado como borracho, ignorante, incapaz, vicioso y mal trabajador. Frente al indio y en clara contraposición, los hacendados modernizantes de la Sierra se mostraban como civilizados y civilizadores, portadores del progreso técnico y cultural.” (Espinoza, 2003, p. 29)
} 
violento, incluso en etapas de severa intoxicación etílica no es común un comportamiento violento. Canelos y Cevallos señalan que los indígenas son dependientes de la madre, y que esta dependencia quizá responda a lo que denominan (sin detalles de a qué se refieren) como "organización social matriarcal". En cuanto a su sexualidad señalan que tienen relaciones pre-matrimoniales "eminentemente superficiales" y que el varón presenta poco interés al sexo opuesto.

En su mayoría, anotan los dos médicos, todos beben. Pero los signos que muestra el indígena patológicamente alcohólico, les resultan aún más preocupantes, pues tienen problemas hepáticos, tendencias al sadismo como manifestación de desahogo frente a sus frustraciones viriles, su instinto sexual se agudiza en estado etílico llegando a la violencia sexual, abandona sus tareas y eso repercute económicamente, viven en condiciones higiénicas deplorables y de promiscuidad con la que "lamentablemente se sienten cómodos". Este medio higiénico deplorable les genera problemas digestivos, infecciosos, más aún al alcohólico que al descuidar su alimentación entra en estado de caquexia y desnutrición. La intoxicación, finalmente, entorpece las facultades mentales "dejando al individuo intelectualmente disminuido" (p. 110).

Otro problema grave para Patricio Canelos S. y Rodney Cevallos T. (1967), es el Chichismo (beber chicha), una bebida que ha sido proscrita por la sanidad y que debería considerarse como bebida alcohólica, pero que en la comunidad es ingerida porque existe el mito de que no hace daño y por el contrario los "aldeanos" la asumen como un patrimonio y un "producto de orgullo propio de su raza", la consideran alimento, y está "mezclado además con un sentimiento de perduración de una raza en vías de extinción y de un misticismo, que constituye tradición con un sentimiento confuso acerca de los daños que puede ocasionar" (p.112).

Según estos médicos, el medio deplorable en el que viven genera la adherencia de "conductas por costumbre" que derivan en el problema del alcoholismo que "representa aproximadamente un tercio de la población, sujetos que presentan una gran dependencia física y psicológica adquirida por medio de la costumbre (...) provocando enormes incidentes que pueden traer consigo graves trastornos sociales (...)" (p.111). Los médicos ponen en consideración que en la misma comunidad las personas que "han logrado cierta cultura superior" presentan un desagrado al consumo y a los consumidores de alcohol. Ello, para los médicos que elaboran este estudio, refuerza aún más la tesis eugenésico ambientalista que considera que el ambiente es capaz de influir en la herencia y por ello ven en "la educación una oportunidad para el mejoramiento racial" (Vallejo y Miranda, 2005, p. 166). Para Canelos y Cevallos, modificar la costumbre para crear otras costumbres que reencausen los caracteres adquiridos en el medio patológico, es una opción para superar el retraso del indígena en pos de los propósitos nacionales y de mejoramiento de la raza. Similar a Perú en donde un higienismo como vertiente positiva de la eugenesia pensó en la 
modificación de costumbres como medida para cuidar la genética (Yzú Rossini, 2016, p. 21).

\subsubsection{El pasado ancestral-ejemplar y el "resentimiento"}

He señalado que el "Tercer Congreso Latino-Americano de Salud Mental” en 1958 resolvió recomendar a los gobiernos un Censo de Enfermos Mentales para una mejor profilaxis mental. A esta recomendación incluyó la necesidad de la formación en psiquiatría básica e higiene mental de los educadores, enfatizó en reconocer el rol de la familia en el desarrollo de la personalidad normal y observó la necesidad de hacer del niño un objeto de supervisión científica psiquiátrica moral ${ }^{51}$. Estas recomendaciones revelan una preocupación apremiante de la psiquiatría Latinoamericana por el bienestar futuro de la nación que se expresa en trabajos colectivos e individuales.

Por su parte, el Dr. Enrique Garcés parece encontrar en lo que ha denominado como "Psicología de la Historia" una vía igual de concreta que las propuestas por el Congreso Latino-Americano de Salud Mental para la profilaxis mental de las naciones. Expone esta propuesta en "Grandeza, Servidumbre y Resentimiento". Éste texto corresponde al IX Capítulo del libro "Daquilema, Rex. Biografía de un dolor indio". El capítulo es publicado en los Archivos de Criminología como un trabajo científico en el que Garcés aplica la Psicología de la Historia de las naciones al caso de Fernando Daquilema, un líder indígena que se considera de sangre real y descendiente de los antiguos señores Puruhas de apellido Duchicela, y que es recordado por rebelarse al sistema político de García moreno en 1870.

Garcés inicia el análisis histórico psicológico de Daquilema en la época prehispánica (lo hace dentro de las cronologías que había enunciado en "Necesidad de una Psicología del padecer de los pueblos"). En este periodo busca las huellas remotas que se han transmitido y grabado de generación en generación y que forman la psique actual de la nación. Es decir, en el análisis histórico psicológico encuentra en Daquilema un arquetipo de la ecuatorianidad y en los orígenes de su psicología los orígenes de la historia y la psicología de la nación. Sangre, psique, soma, territorio, evolución y ancestralidad son los componentes del arquetipo y orígenes de la nación.

En el periodo prehispánico Garcés construye la ancestraliad como hecho (Visacovsky, 2007), como recurso de administración del pasado (Rufer, 2010b) y como pasado ejemplar (Jelin, 2012) para crear un sentido de pertenencia e identidad nacional que se sostiene en el

\footnotetext{
${ }^{51}$ La propuesta de los psiquiatras Latino Americanos respecto de la familia y los niños encaja en buena medida en la de los psiquiatras de la segunda mitad del siglo XIX en Europa que ven en el niño un objeto de prevención-corrección y en la familia el "modelo de tratamiento ortopédico del cuerpo" que reproduce el modelo panóptico para la canalización de los individuos al disciplinamiento y la producción capitalista (Foucault, 2005, p.134). Se trata según Foucault de tener cuerpos productivos, sanos y disciplinados y de tener a la familia como modelo ortopédico psicológico y moral para este propósito, además de tratar a los residuos de la sociedad (delincuentes), residuos de la humanidad (locos) y residuos de la historia (pueblos colonizados) bajo el mismo modelo ortopédico corporal.
} 
tiempo. Este hecho administrable ejemplar es el "Ayllu" al que Garcés (1961) califica de ser la " "primera unidad social que agrupa y organiza a nuestros indios' (...) Ayllu significa, ante todo, linaje, parentela, una misma sangre. Y, además, las relaciones íntimas que se establecen entre el individuo y el paisaje. Sangre y tierra, esencia misma de lo que más tarde ha de llamarse 'patria' (...) Siempre hemos creído nosotros en las raíces tróficas de la tierra como indispensables para la formación de los núcleos sociales.” (p.665)

El Ayllu ecuatoriano (sangre y tierra), según Garcés, se conforma de la suma de "protoplasmas 52 " Puruháes (mezcla de los aportes del norte, sur, oriente y occidente) y "anhelos" para la forja de la nación. Llincabanba y Quito son los "puntos esenciales [en los que] la parábola racial" de la nación se resuelve. Es tan importante la tierra que incluso Garcés llega a desestimar la conquista Inca y sostiene que "Túpac Yupanqui al llegar a tierras ecuatoriales más parece que retorna hacia fuentes ancestrales, antes que venir en son de conquista" (p.666). Garcés realiza esta conexión para centrar en la unión de Túpac Yupanqui y Tópac Colla y su hijo Huayna Cápac el origen de una dinastía, una consanguineidad ancestral que se "mezcla en pos de la fecundidad espiritual" y que "reivindicó el Reino de Quito". A este linaje terminan por pertenecer Los Ati Pillaguazo, Rumiñahui, Cacha Duchicela, Huallara, linaje anclado al "Quito inmortal" con ascendencia de grandeza Inca. Una grandeza que se encierra en secreto en Quera Ayllu en el Valle de Cacha. Es allí donde nace Daquilema "al rededor del año 1845" con un "destino de un mandato irrenunciable dictado por la sangre y la esperanza” (p. 667).

Para fundamentar esta "memoria larga" (Cerda, 2014) de la nación, Garcés imagina una unidad política, territorial, sanguínea y sentimental, cuyos orígenes están en un pasado remoto, un poco anteriores al "Reino de Quito" y no en la independencia de 1830. Esta unidad imaginada corresponde a una grandeza Inca, que en el texto aparece como una especie de unidad afectiva (los matrimonios), territorial (Quito como espacio precolonial de la nación) y espiritual cuya grandeza se transmite en el "protoplasma". En definitiva imagina una nación anterior al Estado Republicano con un énfasis en la raigambre territorial como recurso para construir una identidad nacional, algo que según Ospina (1996) no sucede sino hasta después de la guerra de 1941 con el Perú. Después de esta fecha la cuestión del territorio, cuenta este autor, es fundamental en la imaginación nacional como elemento de diferenciación frente a las naciones vecinas, pues además de los símbolos propuestos por la modernidad cultural, el territorio "reordena (...) los símbolos

\footnotetext{
52 Garcés no es el único médico que, en base a presupuestos teóricos provenientes de la eugenesia positiva y de los propósitos políticos del higienismo, elabora una teleología de las razas. Paz Soldán con relación a la raza peruana y su futuro plantea que la raza se desarrolla desde lo que denomina como "soma ancestral". Para este científico "cada raza en el mudo poseía una carga ancestral que permitía explicar el devenir de su sociedad, además de explicar el crecimiento de su población o el estancamiento de la misma (...) El soma ancestral se concibe como la carga genética propia de una raza que es heredada de una generación a otra. La fertilidad juega un rol importante, pues, para Paz Soldán, existen ciertos grupos humanos que tendrían como característica ancestral una menor cantidad de descendientes e infertilidad" (Yzú Rossini, 2016, p. 55). De allí que considerase que la función de la medicina social y la higiene pública fuesen la modificación de las costumbres y el medio para cuidar la genética y procurar la mejora somática, y a su vez, con la eugenesia salvar las naciones.
} 
de la historia patria, sus orígenes, sus héroes y su futuro" en la medida en que "otorga sentido y significado a una existencia común siempre dudosa (Ospina, 1996, p. 5).

A través de la imaginación de la unidad de territorio y sangre nacionaliza un pasado ejemplar Inca, lleno de grandeza y sin luchas sociales, sin guerras, todo ello es borrado al afirmar que Túpac Yupanqui no llega a territorio andino a conquistar sino que ha retornado a su fuente ancestral. Este ennoblecimiento de un pasado Inca, es un pasado ejemplar que pertenece a la patria ecuatoriana y que forma parte de su identidad porque es adquirido por herencia. Está impreso en el "protoplasma", en la mezcla de sangre, en un mestizaje de larga data "en pos de fecundidad espiritual". El nacionalismo indigenista de Garcés apela a la genética y desde allí genera un aporte que comprende como científico para la construcción de una identidad nacional como hecho inscrito en la sangre. La ecuatorianidad es territorial, cultural y genética. Para Garcés, es allí donde se comprende la psique de la nación.

\subsubsection{El indio somato psíquico/telos-normativo: la psicología de la historia como producción cronotópica del pasado}

Daquilema - dice Garcés- nace en la República, marcado ya por el padecer de la servidumbre en la que la colonia sumergió a los indígenas. Garcés introduce el "resentimiento" como categoría para analizar lo que Daquilema (y el indígena en general a lo largo de su historia) y los mestizos de la independencia ("mezcla de blancos con indios") hicieron con el padecer. El resentimiento para Garcés es un factor importante, "fantástico" para la emancipación de todo el continente. Es el resentimiento el que actúa, "con ferocidad o sin ella, pero siempre tenso, en grito recio". El resentimiento, para Garcés, es un sentimiento que se acumula en las derrotas y que se presenta como una memoria "lacerante y dolorosa" sobre la "atrocidad de la servidumbre", pero a la vez genera nuevas acciones de insumisión ya que alberga la grandeza del pasado prehispánico. El resentimiento a veces aparece "como síntoma de agonía" para enfrentar la servidumbre. Daquilema es ejemplo de ello, en él se refleja esta memoria protoplasmática latente.

Analizar la servidumbre impuesta a una grandeza, que a este Doctor le resulta innegable, y el resentimiento como respuesta permite entender la actitud de los indios en sus alzamientos. De este análisis deduce que sus alzamientos han carecido de un intelecto. Lamenta que el resentimiento y la inteligencia no se hayan conjugado para mover "la roca y briden descanso al Sísifo que el pueblo indio significa", y por el contrario, haya sido el resentimiento el que ha actuado imponiéndose al intelecto. Si bien para Garcés es la actitud insumisa en la que se puede encontrar la grandeza de un pasado que conjuga sangre y tierra, el intelecto sería la organización de la insumisión que llevaría a estos levantamientos a un definitivo triunfo. 
Como categoría de análisis de la psique individual y colectiva, el resentimiento le permite a Garcés administrar un sentido sobre el pasado a razón de que ese pasado ejemplar prehispánico está compuesto de un telos-destino que marca las directrices de hacia dónde debe ir la patria sabiendo, en primera instancia, de donde procede su grandeza y rebeldía. Se trata de un pasado glorioso y ejemplar que actúa como futuro moral y como criterio de civilización en la medida que permite superar el recuerdo de la servidumbre colonial al recuperar una memoria sobre un pasado glorioso, y en la medida en que el intelecto (y el intelectual) pasa a ocupar un lugar central como eje modélico del tipo de ciudadanos que requiere la patria.

\subsection{Psicología de la raza india, biotipo, la "grandeza interrumpida" y el ambiente}

Garcés toma su modelo de análisis psicológico de la historia para establecer, una vez más la normalidad del indio. A través de la determinación del biotipo sostiene que el "indio ecuatoriano es un pícnico inconfundible". Discrepando con el biotipo establecido por Cueva, dice que si se registran asténicos y atléticos será por excepción, "al menos en los grupos humanos de la familia quichua. Y siguiendo la doctrina constitucionalista que correlaciona con el temperamento [es] ciclotímico extravertido." A su vez "el indio corresponde al subtipo de los callados y pesimistas, con sospechosa anestesia afectiva en ciertos casos que no se refieran a problemas de su propia familia y grupo de sangre. La tranquilidad del aborigen, nos coloca frente a un hombre en soledad singularmente." (p.668).

Garcés observa que a menudo el comportamiento ambivalente de los indios responde a una desconfianza que sienten frente a los blancos y los mestizos. Respecto a ello, observa que el indio es un extravertido cuando está dentro de su mundo, pero fuera de éste es bastante introvertido. No haber notado este detalle ha conducido a las investigaciones a confundirse, en lugar de ver una reacción necesaria que proviene del resentimiento cuando están frente al blanco o mestizo, se ha desviado las conclusiones sobre su tipo mental a tribuyendo a este comportamiento complejos de inferioridad y debilidad mental que el indio no posee. Aquí discrepa tanto con Cueva Tamariz como con Canelos y Cevallos quienes sí encuentran un complejo de inferioridad en el indígena.

Para este médico, el indio no padece debilidad mental alguna como "síndrome neto", lo que hay es una tendencia, "incluso de quienes lo defienden", a apuntar datos que avalan su "postración espiritual ocasionado por sojuzgamiento ignominioso" el supuesto sentimiento de minusvalía del indígena hacia sí mismo. Para Garcés, ejemplo de la inexistencia de debilidad mental del indígena es su capacidad para salir adelante pese a las dificultades y el rendimiento al que puede llegar comparado con el mestizo. El indio puede llegar a ser destacado si, como Eugenio Espejo (un recurrente prototipo indigenista sobre lo que el indio puede llegar a Ser en un ambiente de cultura y civilización), tiene acceso a las artes, 
la ciencia, las letras -afirma Garcés-. Citando el trabajo de Endara plantea que sus problemas psicológicos no responden a la patología, sino el ambiente.

Muestra de esto - dice Garcés darwiniana y sobre todo lamarckianamente- es que "Los Ayllus" estaban en "progreso ascendente" en el mismo proceso de evolución de hombre occidental, "siguiendo la ruta de la perfección del hombre que es la historia desde la monera, el alga o el infusorio, hasta el homo sapiens, económico o políticus." Vemos aquí un argumento que suma Lamarck con la selección natural en la medida que ve en la evolución una tendencia ininterrumpida hacia le perfección de la especie y su adaptación al medio. Prueba de que el indígena está en la misma cadena de evolución del hombre occidental es la forma del pulgar que le permite sujetar objetos con sus manos. Garcés prosigue diciendo que la unión de las tribus (Puruháes y Shyris) que origina el Reino de Quito, "respondía a una etapa cultural de grandeza aborigen", y ello constituiría otra prueba. Este periodo tiene una "mente colectiva" y lo "mágico de ella es que se da pese a la incultura" de las tribus. Eso para Garcés, demuestra que "su cerebro está maduro" y por ende su inteligencia. Por ello es comprensible para este médico que los indios separados de su medio llegaran a ser notables intelectuales como Eugenio Espejo.

Retoma los ejemplos que al respecto proporcionó el Profesor Rivet para el Ecuador. Habla de un Jíbaro que al separarse de su medio se fue a Italia y se doctoró en fílosofía destacando. Aunque al volver a su tribu "abandonó sus ropas de europeo" y se perdió para siempre. Garcés atribuye ese comportamiento al resentimiento. También toma como ejemplo al "niño Salasca" adoptado por el doctor uruguayo José Luis Bado y que en este país terminó la escuela con aprovechamiento. También le resulta indudable el aporte al mestizaje latinoamericano que realiza el indio con su huella de grandeza. Por ello para Garcés, el indio es un "retrasado cultural y no mental", pero no por "degradación sino por interrupción" del progreso ascendente del Ayllu. Un proceso evolutivo fue interrumpido por la servidumbre de la Colonia, la tarea es encausarlo y retornarlo a su grandeza, a través de la grandeza de "nuestra libertad y democracia", en "una Latino América humana". El indio para Garcés, en otro ambiente, no tendrá "apatía por cultivarse", como sugiere Cueva, lo hará por que en otro ambiente su evolución interrumpida puede resurgir.

Para que se desarrolle en las mismas condiciones de ambiente que los blancos y los mestizos, hay que trasladar al indio a otro ambiente más culto, ilustrado, moderno, distinto al descrito por Canelos y Cevallos. Hay que cultivarlo en ciencias, educarlo en buenas costumbres y procurar ese camino profiláctico de las razas con la ciencia y la democracia y la exactitud y libertad que ellas aseguran. Pero también, para Garcés, se trata de orientar una grandeza inscrita en el protoplasma de toda la nación. Por ello, no se trataría solo de los indios, sino de una orientación que conviene a toda la nación porque es fuente misma de la imaginación que la erige. Para ello hay que orientar su "psicología de masas" que es el tipo de psicología que tiene el indio, motivada por el resentimiento. La psicología del indio 
es su espíritu Ayllu, "mentalidad mágica de raza”, pero también es esta su desventaja, porque es grandeza indeleble en la sangre, pero conducida sin intelecto. "Daquilema es un eslabón de la cadena que integran la grandeza, la servidumbre y el resentimiento. Los héroes indios no se entregaron a su misión para dejar partes guerreros o episodios en la historiografía. Lo hicieron obedeciendo el mandato irrenunciable de su grandeza azotada por la servidumbre que sembró tan terrible resentimiento." (Garcés, 1961, p. 676).

Eugenesia, indigenismo e higienismo aparecen cruzados en esta propuesta. Pero más que mezclar la idea eugenésica de mejoramiento genético con la de prevención higiénica, característica de la eugenesia en Ecuador como dice Serrano (2016), o apostar, como Paz Soldán en Perú por la modificación de las costumbres y el medio a través de la medicina social y la higiene pública para cuidar la genética que guarda el "soma ancestral" y procurar así la mejora somática y el rescate de las naciones, Garcés propone aquí la idea de prevención profiláctica-demofilactica como modificación de las costumbres y el medio a través de la ciencia no solo para cuidar la genética, sino para procurar el re-surgimiento de una grandeza latente en la genética del indígena y de la nación ecuatoriana. En Garcés, la profilaxis-demofilaxis no es solo cuidado y prevención, sino retorno.

En este sentido el "hallazgo", por decirlo de algún modo, al que llegan los psiquiatras sobre la ausencia de patología mental o biológica de los indígenas es una forma de argumentación científicamente sustentada a favor de la entera inclusión de los indígenas en la imaginería nacional y la vida moderna. Si el problema no es mental ni biológico, el sujeto puede ser incluido en la imaginería nacional. Sus limitantes para habitar el proyecto nacional moderno irían por otra vía, y lo más importante, según esta postura, es que esos límites pueden ser atravesados, solucionados, diluidos bajo ciertas condiciones. Es allí donde toma de nuevo importancia el debate sobre el ambiente y la educación, como lo manifiesta Garcés al postular lo que se puede lograr si se coloca al indio en otro ambiente. Pero también es aquí cuando el indígena entra en escena como modelo civilizador o modernizador de sí mismo, el indígena mítico pasa a ser una apuesta regulatoria del indígena real para su modernización y a su vez de la nación.

No se trata de asumir el cuerpo desde el "instinto genésico" del que habla el eugenesista ecuatoriano Domínguez en los años 30, para tener "presente en sociedad que el cuerpo humano debe estar en óptimas condiciones para que la reproducción y la herencia no se vean afectadas de forma negativa y esto cause a su vez problemas futuros de salud" (Serrano, 2016, p.32). No, para Garcés se trata de asumir el cuerpo en función del protoplasma que porta, y que se dibuja en un pasado ejemplar dotado de un telos que se proyecta al futuro de la nación moderna. Los psiquiatras objetivan al indio en su saber y en ese movimiento se convierte en un objeto de civilización, pues el telos-destino con el que es categorizada su normalidad contiene ahora en Garcés el tiempo de la pedagogía nacional y 
el tiempo de su escenificación: identidad continuamente escenificada en el pasado ejemplar del Ecuador.

Entonces, ya no solo se trata de la cronotopía regulatoria como agenciamiento de la subjetividad a la que apostaba Cueva, sino de la cronotopía regulatoria como autoagenciamiento. Al colocar una semiótica de indio que conjuga la grandeza en un pasado ejemplar, Garcés traslada al indio arqueológico mítico al futuro como una imagen brújula del deber ser: el indio arqueológico mítico pasa a ser un indio telos-normativo, una normativa del Yo desde el sí mismo, un ideal por alcanzar-recuperar, una identidad que habita al ecuatoriano y que puede y debe emerger desde su interior y frente a cada individuo como sentido de unidad nacional. La ecuatorianidad ya no es solo una "vivencia que debe incorporarse", como sostiene Garcés años atrás, sino una memoria genética que puede retornar a través de la conducción científica y el auto-agenciamiento de la subjetividad.

Aquí, el principio normalizador moderno de inicios del siglo XX, no deja de ser una forma de normalización moral sesenta años después. Retoma el criterio binario bien-mal, saludenfermedad de la salud moderna que emergió a finales del siglo XIX (Osorio, 2014, p. 79) y con la misma compulsión binaria compone criterios de normalidad-anormalidad en torno a la oposición civilizado-incivilizado en base a criterios médicos y representaciones nacionales eugenésicas-higienistas-indigenistas otrificadoras de tiempo. Pero, ya no solo para administrar el presente a través de mecanismos de control y tutelaje estatal, sino para administrar el presente desde el futuro a través de un pasado dotado de una telosnormatividad cronotopica en la que los sujetos, para devenir ciudadano, se auto-regulan.

Entonces, como sucede en el momento histórico en el que se construye la noción de ciudadanía, el indígena, para devenir ciudadano, ya no solo debe reconocerse, como plantea Osorio (2014), como "un cuerpo sujeto a leyes físicas y naturales" que se desarrollan óptimas si se aleja de la patología. Ahora debe reconocerse en los ideales de la nación, debe reconocerse en el futuro y caminar hacia éste como una normalidad aceptada y que por su potencial para ser civilizada debe ser mantenida, debe reconocerse en la grandeza genética de su pasado, en la normalidad del presente de su biotipo y en el resurgimiento futuro de su grandeza genética, debe reconocerse en una nueva temporalidad como un cuerpo y una psique moderna y normal posible... aceptada...porvenir. 
CAPÍTULO 6 


\section{6.- A manera de conclusiones}

En las líneas que acaban de concluir encontramos al indígena como objeto de saber dentro de un campo de visibilidad y un horizonte de expectativas psiquiátricas Biológico constitucional. El mismo involucra una ramificación teórica que se extiende por la Eugenesia, la Higiene, la Antropometría, la Estadística, la Criminología, la Teoría Constitucional, la Biología, el Psicoanálisis, la Antropología Endócrina, la Historia. A su vez, la visibilidad y la expectativa se hallan concatenadas con una apuesta teórica y política por la elaboración de un relato Biológico constitucional de la nación en un contexto de reconstrucción del espacio simbólico de la nación tras la pérdida territorial en la guerra con el Perú en 1941.

El campo de visibilidad Biológico constitucional que se gesta en un sector de la psiquiatría en la sierra ecuatoriana, postula una forma de constituir tanto los hechos históricos del pasado como el devenir del individuo y su historia. A la vez que este campo define objetos de saber, actúa también como una concepción nativa de tiempo con la que se define la identidad moderna, dando lugar a un modelo con estructura de saber y estructura de tiempo, pues a la vez que permite relatos disciplinares y narrativas sobre hechos históricos, define divisiones político-geo-temporales (asignaciones políticas de tiempo y espacio) de las identidades, tanto para los objetos y sujetos del saber, como para la otrificación (producción de alteridad) nacional.

Ahora bien, la psiquiatría en el Ecuador llega a la mitad del siglo XX con un amplio horizonte de expectativas, pues su desarrollo ha sobrepasado la práctica alrededor de la clasificación nosológica y la definición etiológica sobre la enfermedad mental y el ejercicio de la profesión dentro del Hospital Psiquiátrico. Los objetos de la psiquiatría abarcan toda clase de realidades. El establecimiento de la relación entre Crimen y Psiquiatría amplía la capacidad de aprehensión de objetos del campo de visibilidad psiquiátrico que conjuga a la vez saber jurídico, endócrino, antropológico-clínico, estadístico, antropométrico, biológicosocial, psíquico, psicoanalítico, morfológico, sociológico, preventivo, clínicoconstitucional. Mediante este campo, la psiquiatría se ve en la capacidad de hacer inteligible la raza, la locura, el crimen, la sexualidad, la mujer, la biología, la cultura, el organismo, llegando a ocuparse de la historia misma del país, de su re-escritura y de su conducción. Es así que el vínculo entre Criminología y Psiquiatría, al enlazar Eugenesia, Higiene, Sociología, Psicoanálisis, Jurisprudencia, Patología mental y Antropología Endócrina, permite la configuración de un sistema clasificatorio somato psíquico que produce un saber sobre el individuo e institucionaliza un relato científico sobre la raza y la identidad Ecuatoriana.

En este marco, se busca determinar las causas de la incivilización del indígena. Tras una evaluación psicoanalítica minuciosa del tipo mental del indígena, se determina su normalidad. El indígena no parece impedido emotiva ni intelectualmente para ser 
incorporado a la civilización. Sin embargo, la normalidad que se le descubre no lo exime de su estado de rezago frente a la civilización, de hecho la explica, la reafirma y la redefine, pues la normalidad es definida en relación a la capacidad del indígena de adscribirse a la modernidad, no como sujeto político que da cuenta de sí mismo, de su cultura, de su memoria y de su historia, sino en su capacidad de incorporación a pesar de ser un presente atávico: un rezago del progreso biológico y nacional que solo al configurarse como objeto de saber es concebido objeto civilizable y posible ciudadano.

Tras el descubrimiento de la normalidad psíquica en el tipo mental del indígena, las disertaciones sobre el indio giran en torno a definir el cuerpo de esa psicología. Para ello la Biología constitucional marca una distancia con estudios realizados en el siglo XIX por médicos franceses que fueron reeditados en la década de1950, y que constituirían una escuela para la psiquiatría y la medicina ecuatoriana. Esta escuela atribuyó al cuerpo anatómico del indígena una serie de rasgos patológicos que lo incapacitaban para la vida civilizada. Al cuerpo anatómico, en la Biología constitucional, se antepone el indio somato psíquico, constituido por un biotipo compuesto por un tipo mental, un tipo fisiológico, un tipo endócrino y un tipo somático. Sobre este último habrá ciertas discrepancias sobre si definir al indígena desde las estructuras corporales de Kretschmer como un tipo Atlético o un Pícnico. Las discrepancias sobre tal definición se suscitan sobre todo por la correlación entre estructura corporal y temperamento. Por una parte, esto pone de manifiesto no solo tensiones dentro del campo de visibilidad, sino el cuidado por la exactitud de las categorías con las que se define la estructura corporal y su correlato en el temperamento. Y ello será importante porque la Biología constitucional, en su concepción nativa del tiempo, además de postular una narrativa sobre el presente y el pasado, también encuentra en el temperamento el devenir de la historia.

Por otra parte, discrepar no pone en duda la normalidad del indio, sino más la etiología de su comportamiento frente al Estado, frente al proyecto de nación, frente a los blancos y mestizos y frente a sus iguales. Y, a partir de aquí, se busca establecer la presencia o ausencia de un complejo de inferioridad en el indio ya que de esa categorización dependen, en parte, las estrategias a adoptar para acompañar al indio en su tránsito a la civilización.

La Biología constitucional, entonces, halla en el cuerpo psico-bilógico o somato psíquico, una estrategia científica para la civilización del indígena, un elemento de la producción de historia, para definir la identidad politico-geo-temporal de quienes pueden producir esa historia, y para producir la regularidad sobre la inteligibilidad de los objetos de saber con los que, a su vez, se produce el sentido histórico-psicobiológico de la sociedad a la que nombra desde ese sentido político-histórico-psicobiológico-geo-temporal.

La normalidad psíquica del indígena y posteriormente somato psíquica, aparece para los médicos-psiquiatras como un hallazgo científico de grandes proporciones políticas: define las vías de incorporación del indígena a la modernidad, marca distancias temporales y 
conceptuales con otras tradiciones científicas, proporciona un campo teórico para la inteligibilidad de la raza y traza nuevas coordenadas para la definición de la normalidad. A su vez, en la medida que delimita identidades político-geo-temporales y produce historia, conecta estos elementos con la imaginería de una identidad nacional y transnacional indigenista en oposición a los racismos provenientes de Europa, América del Norte y de sectores políticos y científicos de Latinoamérica y Ecuador.

Ello no quiere decir que rechacen los postulados teóricos de las corrientes europeas, más bien hay una reelaboración y una adecuación del uso, un efecto desdoblador enmarcado en los propósitos de una imaginería de la nación postulada desde una ventriloquía indigenista psiquiátrica, principalmente en lo que concerniente al uso local que se tiene de la eugenesia y la teoría constitucional de Kretschmer, con las cuales, los psiquiatras ecuatorianos apuntan a construir categorías antropológicas que permitan definir al otro-indígena en la dicotomía normal/anormal civilizado/incivilizado.

Es así que en la narrativa psiquiátrica de la nación se expresa, a la manera de la eugenesia, un deseo por la limpieza, no a la usanza de la ontología teológica de la pureza de sangre, ni del todo a la usanza de la clasificación naturalista del racismo científico que pone el acento en lo innato-natural y hereditario a partir de una mirada binaria (Stolcke, 2009). Si encontramos latente el degeneracionismo en torno a la herencia y la mirada binaria moderna, y en lo que respecta a lo que se atribuye como propio de cada raza, no es para sustentar la anormalidad o el descenso evolutivo del indígena, sino más bien para redefinirlo y rebatirlo. Ello, sin que la tendencia binaria de la modernidad deje de producir dicotomías en la lectura de la raza a través de la oposición civilizado/incivilizado normal/anormal.

Entonces, el deseo por la limpieza aquí no distingue destinos biológicos irresolubles en el indígena, sino amenazas de destino y posibles modificaciones y conducciones científicas civilizatorias modernizantes de los indígenas. Si el indígena aparece en el campo de visibilidad Biológico constitucional como objeto de saber psiquiátrico y a su vez como objeto civilizable y posible ciudadano, ello ocurre porque esta mirada eugenésicohigienista-indigenista-psicoanalítica-ventrílocua no se posa netamente sobre la biología ni sobre el cuerpo anatómico, sino sobre el ambiente en primera instancia, y en ese desplazamiento el deseo de limpieza evoca y rememora a la patria de una forma distinta a la degenracionista.

De allí que en el modelo Biológico constitucional encontremos al indígena dentro de una dinámica en la que su frontera como objeto de saber psiquiátrico se funde con la de "peón semiótico" de la nación (Muratorio, 1994). El indígena somato psíquico, a la vez que es un hallazgo teórico, es también un elemento de imaginación de la nación, una especie de bisagra, un conector somático entre el relato disciplinar y la narrativa nacional. 
Es así que la eugenesia-higiénica en el Ecuador (Kingman, 2008; Serrano, 2016) a partir de los años 20, junto a la modernidad cultural de mediados de siglo (Polo, 2002) dan paso a la emergencia de campos conceptuales desde los que se postula una utopía que condiciona el progreso de la nación a la indagación científica y moderna sobre el SER nacional, lo que condujo al establecimiento de taxonomías de definición de jerarquías sociales que se remiten, en parte, a la reelaboración de esencias físicas, culturales y biológicas para la definición de ese SER nacional.

En este campo conceptual psiquiátrico que define los términos de verificación de la normalidad, el indígena es investido por una identidad híbrida debido a que, al contener el efecto desdoblador que responde a políticas conceptuales, el campo de visibilidad genera un híbrido epistemológico, otorgándole identidad étnica y social, pero también define al indígena como objeto de saber y viceversa.

Esta hibridez conceptual también contiene un montaje de tiempo (sobre un pasado grandioso, una perspectiva de futuro y un presente atávico) que conecta la concepción del indígena, como objeto de saber psiquiátrico y su identidad étnica y social, con los tiempos de la nación, con la pedagogía y la escenificación de la nación. Este montaje de tiempo se despliega en el cuerpo y la psique del indígena. Y para que el tiempo se haga cuerpo y psique, el indígena es objetivado, diagnosticado, otrificado, clasificado, historizado e incorporado como objeto de saber psiquiátrico en la narrativa de la ecuatorianidad. En el montaje de tiempo sobre cuerpo y psique se determina la relación entre pasado, presente y futuro de la nación.

Desde el campo de visibilidad que se compone, la Teoría Constitucionalista, el método tipológico, la temporalización del indígena y el hallazgo de su normalidad permiten, además, la definición de su biología, su psique, su nacionalización y su mitificación. Desde este cuerpo teórico se organiza una forma de clasificación de los objetos, que en el abordaje de la raza, la psique, la herencia y el ambiente, empata la Teoría constitucional con la profilaxis eugenésica $\mathrm{y}$, a ello agrega herramientas teóricas del Psicoanálisis como el concepto de proyección, represión, asociación libre, teoría de la sexualidad.

La eugenesia, como un cuerpo teórico que abarca un amplio espectro científico que alimenta el campo de visibilidad psiquiátrico Biológico constitucional, y que goza de una aceptación y reputación social y científica extendida tanto en regímenes totalitarios como en las democracias en formación, actúa al interior del campo psiquiátrico como una herramienta multiforme de aprehensión de objetos de saber y como un elemento de la imaginería de utopías sociales y nacionales. De hecho, las distintas disciplinas que articulan la narrativa psiquiátrica actúan como esferas de sentido, como imaginerías que realizan conceptualizaciones geo-temporales de una sociedad que conlleva una voluntad de acción en pos de la orientación adecuada y científica de la sociedad. 
En este sentido se ha postulado a la eugenesia como una cronosofía, en la medida que permite realizar un relato único e idealizado/divisor/jerarquizante del tiempo complejo (pasado/futuro/presente) y el espacio heterotópico. A su vez es una forma de otrificación que define al otro y al nosotros de lo normal y lo anormal con el ánimo de incidir en la herencia y el ambiente, y en definitiva en el devenir. Como cronosofia idealizadora/divisora/jerarquizante/otrificadora, anexa la voluntad de acción con una forma legítima de construir sentido sobre el tiempo histórico y social instituido en una noción de tiempo biológico científicamente conducido que se corresponde, a su vez, con la fe en el telos-destino y con la expresión poética de cada nación.

Gracias a que la eugenesia da lugar a la instrumentalización del tiempo en el campo de visibilidad Biológico constitucional, los médicos y psiquiatras realizan conexiones entre los objetos de saber y la identidad nacional. Es así que el padecer se postula como una categoría para comprender una manifestación de la psicología de masas y la actitud de un pueblo frente al dolor y la pena. Ello define su identidad de un pueblo, puesto que en esa actitud se puede ver su capacidad de concebir su libertad y su capacidad de acción para alcanzarla.

La narrativa psiquiátrica, a través estas categorías, realiza una lectura de la historia y vislumbra en el resentimiento, característico del comportamiento del indio, un rasgo de la identidad ecuatoriana, y a la vez postula una teoría sobre una biología evolucionada congelada en el tiempo, pero latente en el protoplasma. Mediante un análisis psicológico histórico, el campo de visibilidad constituye y administra un pasado ejemplar prehispánico en el que encuentra las huellas del origen de una psicología del presente de la nación: sangre, psique, soma, territorio, evolución interrumpida y ancestralidad, son los componentes del arquetipo psíquico y de los orígenes remotos de la nación. Aquí se retoma a Darwin, desde una lectura más lamarkiana, para postular la evolución como progreso y adaptación al medio; una perspectiva en la que, a diferencia de la teoría de la degeneración, la evolución es comprendida como continuo perfeccionamiento. Desde allí se perfila una característica de la normalidad del indígena en términos evolutivos (perfectibles/recuperable): el indígena se encuentra en un continuo progreso cuyo estado evolutivo en el pasado prehispánico puede ser igualado a la de civilizaciones europeas, su rezago en el presente moderno no corresponde a la degeneración, sino a un detenimiento de la evolución por actuación del medio sobre su biología y su psique. Por ende, hay que cambiar al indígena de medio para que su evolución continúe desde donde se quedó a causa de la colonización.

La narrativa que se genera en el campo de visibilidad sitúa en ese pasado ejemplar la grandeza interrumpida de la nación y las vías para su resurgimiento a través de lo que se denominan como prevención profiláctica-demofilactica, que consiste por una parte en la modificación de las costumbres y el medio, pero a través del tutelaje científico para generar 
el reconocimiento de ese pasado ejemplar como una grandeza grabada en el protoplasma y, por otra parte involucra el reconocimiento de esa grandeza del pasado en el devenir de la nación. A su vez, la narrativa sobre el indio de la serranía que se liga a una comprensión epistémica de la construcción de la normalidad moderna en la que, la concepción sobre lo normal y o patológico, no responde a algún tipo de condena, sino más bien a estrategia de modernización de los sujetos atávicos. El indígena entonces no es visto ya como un sujeto patológico, sino más bien como normal, y es esa normalidad la que le permite superar su condición de rezago, la que le permite ser modernizado.

Es aquí cuando el indio somato psíquico se funde y se difumina en el indio mítico, y el montaje de tiempo pasa a ser una apuesta regulatoria cronotópica telos-normativa para el agenciamiento y el auto-agenciamiento de la subjetividad del indígena y de la población ecuatoriana, dado que es una imagen ideal del pasado que habita el futuro, y que para el caso del indio, actúa como una normalidad que el indio normal atávico, somato psíquico, civilizable y admitido por la narrativa Biológico constitucional, debe sostener para ocupar un lugar en ese futuro de la nación.

La ventriloquía psiquiátrica indigenista, al buscar huellas del origen de la nación, como un proyecto histórico que cabe en la narrativa Biológico constitucional, a través de sus concepciones nativas de tiempo, toma los rasgos psíquicos que encuentra en el indígena y los constituye en hechos para la producción de identidad nacional. En esta operación otrifican al indígena asignándole una identidad ideal, que como representación psiquiátrica del indígena, actúa como una contención que retiene al indígena en esa representación ideal. Aquí, el indígena, a pesar del uso del psicoanálisis, no es un sujeto político o histórico que expresa su deseo, es el otro representado en un sí mismo ideal, más presente en el nosotros de la identidad moderna que se arrogan los psiquiatras que en una representación proveniente de su propia palabra. Y, es así que, para ser un nosotros moderno debe convertirse en el sí mimo normal civilizable que se le ha asignado en el futuro.

La aprehensión del indígena en la narrativa Biológico constitucional, no obstante a su idealización, advierte la necesidad de su tutelaje, al hacerlo asume al indígena desde su inferioridad. Mientras que el indio mítico es un modelo de civilización en la imaginería nacional, el indio somato psíquico, aunque sus rasgos raciales sean normales y admitidos, es un indio en falta, incompleto, pero posible. Esta mirada ambigua retoma al indio de la narrativa sobre el dominio étnico proveniente del ventriloquismo político liberal (Guerrero, 1994), pero esta vez para dar cuenta de su normalidad que, aunque atávica, es civilizable. Esta concepción responde a una comprensión epistémica de la construcción de la normalidad moderna en la que la definición de lo normal y lo patológico no parte de las evidencias de la degeneración en el cuerpo, sino de los efectos del ambiente sobre la genética y el cuerpo, y en la que ya no se aboga por la condena exclusiva del indígena, sino 
por su modernización positiva a través de estrategias de regulación profilácticas médicopsiquiátricas para la autogestión de la subjetividad. 


\section{Bibliografía}

Anderson, Benedict. (2007). Comunidades imaginadas. Reflexiones sobre el origen y la difusión del nacionalismo, México, Fondo de Cultura Económica.

Agamben, Giorgio. (2009). ¿Qué es un paradigma?. En: Hidalgo, Adriana, Signatura rerum. Sobre el método.

Allan, Henrry, Clase media, Universidad privada y revolución ciudadan. Revista malaidea No 1. Quito-Ecuador. Junio, 2011.

Argueta, Arturo, y Ruiz Rosaura (2002). Darwin en Bolivia y México. En: Puig-Samper,

Miguel Ángel, Ruiz, Rosaura y Galera Andrés (Editores). "Evolucionismo y Cultura. Darwinismo en Europa e Iberoamérica”, México, Edicones Doce Calles.

Ayala, Paulo. (2017). Estadio Atahualpa, selección nacional, y racismo: el futbolista negro en el imaginario social ecuatoriano. Tesis para la optar el título maestría en Investigación Antropológica. Quito, FLACSO- Sede Ecuador.

Balbo, Eduardo. A. (2002). Charles Darwin y la psiquiatría. En: Puig-Samper, Miguel Ángel, Ruiz, Rosaura y Galera Andrés (Editores). "Evolucionismo y Cultura. Darwinismo en Europa e Iberoamérica", México, Edicones Doce Calles.

Barbero, Jesús, (s.a). El futuro que habita la memoria. Departamento de Estudios Socioculturales $\quad$ ITESO-México. Recuperado de https:/esjatologico.files.wordpress.com/2010/09/el-futuro-que-habita-la-memoria2.pdf

Bourdieu, Pierre. (2001). ¿Qué significa hablar?. Madrid, Akal.

Bhabha, Homi K. (2010). Introducción: narrar la nación. En: Nación y narración: entre la ilusión de una identidad y las diferencias culturales, Homi K. Bhabha (Comp.), Buenos Aires: Siglo XXI editores.

Chatterjee, Parthe (2008). La nación en tiempo heterogéneo: y otros estudios subalternos, Buenos Aires, Siglo XXI editores. 
Cadena, Marisol de la. (1997). La decencia y el respeto: raza y etnicidad entre los intelectuales y las mestizas cuzqueñas. Lima: IEP. (Documento de Trabajo, 86. Serie Antropología, 12).

- (enero-junio 2006). ¿son los mestizos híbridos? Las políticas conceptuales de las identidades andinas. Universitas Humanísticas. n. 61. Recuperado de http://www.redalyc.org/articulo.oa?id=79106103

Campos, Ricardo, y Novella, Enric. (18 de marzo 2016). La higiene mental durante el primer franquismo. De la higiene racial a la prevención de la enfermedad mental (19391960). Dynamis. Recuperado de http://scielo.isciii.es/pdf/dyn/v37n1/04 dossier.pdf

Campos, Ricardo. (abril 2016). Autoritarismo y eugenesia punitiva: higiene racial y nacionalcatolicismo en el franquismo, 1936-1945. História, Ciencias, Saúde-Manguinhos, Rio de Janeiro. Recuperado de http://www.scielo.br/pdf/hcsm/v23s1/0104-5970-hcsm-23$\underline{\text { s1-0131.pdf }}$

Castel, Robert. (2009) El orden psiquiátrico. La edad de oro del alienismo -1 a ed. - Buenos Aires: Nueva Visión.

Cerda, Alejandro. (1 de marzo 2014). Memorias largas y cortas: tensiones para su articulación en el campo indígena. Clepsidra, Revista Interdisciplinaria de Estudios sobre Memoria. Recuperado

de http://ppct.caicyt.gov.ar/index.php/clepsidra/article/viewFile/CERDA/pdf

Clau, Montserrat. (s.a). Pasado y Futuro del presente etnográfico: Una introducción. Recuperado de http://blogs.uab.cat/ahcisp/files/2011/11/introducci\%C3\%B3n-mesa-detrabajo-Leon.2011.pdf

De Certeau, Michel. (1993). La escritura de la historia. México, Universidad Iberoamericana Departamento de Historia.

Díaz de Rada, Ángel. (9 noviembre 2014). La ironía de ser indígena y la imaginación del tiempo social. Revista de Antropología Social. Recuperado de file://C:/Users/User/Downloads/50667-90672-2-PB\%20(1).pdf 
Dosse, François. (2010). El acontecimiento histórico entre Esfinge y Fénix. Historia y Grafía. Universidad Iberoamericana, año 21, núm. 41, julio-diciembre.

Echeverría, Bolívar. (2011). Ensayos políticos”. Quito: Ministerio de Coordinación de la Política y Gobiernos Autónomos Desentralizados. Colección Pensamiento Político Ecuatoriano.

Castro, Edgardo. (2004). El vocabulario de Michel Foucault. Un recorrido alfabético por sus temas, conceptos y autores. Bernal: Universidad Nacional de Quilmes.

Foucault, Michel. (2010). La historia de la locura en la época clásica. México: Fondo de Cultura Económica tomos I y II.

XXI editores.

. (2010). Vigilar y castigar: nacimiento de la prisión, Buenos Aires, Siglo médica, Buenos Aires, Siglo XXI editores.

Económica.

- (2005). El poder psiquiátrico, Buenos Aires, Fondo de Cultura

Fitzell, Jill. (1994). Teorizando la Diferencia en los Andes del Ecuador: Viajeros Europeo, la Ciencia del Exotismo y las Imágenes de los Indios. En Blanca Muratorio (Ed.), Imágenes e Imagineros: representaciones de los indígenas ecuatorianos Siglos XIX y XX (pp. 9-24). 1 a edición, FLACSO-Sede Ecuador.

Gorbach, Frida. (2008). El monstruo, objeto imposible: Un estudio sobre teratología mexicana. México: ITACA.

. (2007). El encuentro de un monstruo y una histérica. Una imagen para México en los finales del siglo XIX. Nuevo Mundo Mundos Nuevos, Debates. Recuperado de https://journals.openedition.org/nuevomundo/3123 https://journals.openedition.org/nuevomundo/3123

. (2012). La Historia, la Ciencia y la Nación. Un estudio de caso en el México decimonómico. Dynamis, Universidad Autónoma Metropolitana, Xochimilco. Recuperado de http://scielo.isciii.es/scielo.php?script=sci arttext\&pid=S0211$\underline{95362013000100006}$

Guerrero, Andrés. (1994). Una Imagen Ventrílocua: El Discurso Liberal de la "desgraciada raza indígena" a finales del Siglo XIX. En Blanca Muratorio (Ed.), Imágenes e Imagineros: representaciones de los indígenas ecuatorianos Siglos XIX y XX (pp. 197). 1 a edición, FLACSO-Sede Ecuador. 
. (1997). Poblaciones indígenas, ciudadanía y representación. QuitoEcuador: Nueva sociedad No. 150 julio-agosto.

Chaves, María. (2009). Genealogía de la diferencia: Tecnologías de la salvación y representación de los africanos esclavizados en Iberoamérica colonial. Bogotá: Editorial Pontificia Universidad Javeriana, Instituto de Estudios Sociales y Culturales Pensar, AbyaYala.

Landázuri Camacho. (2008). Mariana, Salir del encierro: medio siglo del Hospital Psiquiátrico San Lázaro. Quito: Banco Central del Ecuador.

Huertas, Rafael. (2012). Historia cultural de la psiquiatría (Re)Pensar la locura. Madrid, Los libros de la Catarata. . (2002). Darwinismo y Darwinismo social en la obra de E. Zola. En: PuigSamper, Miguel Ángel, Ruiz, Rosaura y Galera Andrés (Editores). "Evolucionismo y Cultura. Darwinismo en Europa e Iberoamérica”, México, Edicones Doce Calles.

Jelin, Elisabeth. (2001) Los trabajos de la memoria, Buenos Aires, Siglo XXI editores.

Kingman, Eduardo. (2008). La ciudad y los otros Quito 1860 - 1940: Higienismo, ornato y policía. Quito: FLACSO Sede-Ecuador-FONSAL-Universitat Rovira i Virgili.

Koselleck, Reinhart. (2008-2009). Para una historia de los conceptos: problemas teóricos y prácticos. En: Discurso crítico y Modernidad. Revista Contrahistorias, la otra mirada del Clío, N. 11. p.p. 75-88.

Landázuri, Mariana. (2008). Salir del encierro: medio siglo del Hospital Psiquiátrico San Lázaro, Quito, Banco Central del Ecuador.

Martínez, Ángel. (2011). La copia de los hechos. La biomedicina, el poder y su $\begin{array}{llll}\text { encubrimientos. } & \text { Dialnet. } & \text { N.27. }\end{array}$ https://www.raco.cat/index.php/QuadernsICA/article/view/258369/351469

McGraw, Jason. (agosto 2007). Purificar la Nación: eugenesia, higiene y renovación moralracial de la periferia del Caribe colombiano, 1900-1930. Revista de Estudios Sociales, núm. 27, Universidad de Los Andes, Bogotá, Colombia. Recuperado de https://revistas.uniandes.edu.co/doi/pdf/10.7440/res27.2007.04 
Miranda, Marisa y Vallejo, Gustavo. (2005). Darwinismo social y eugenesia en el mundo latino, complilado por Marisa Miranda y Gustavo Vallejo, $1^{\mathrm{a}}$ ed, Buenos Aires, Siglo XXI de Argentina Editores.

Muratorio, Blanca. (1994). Discursos y silencios sobre el Indio en la Conciencia Nacional. En Blanca Muratorio (Ed.), Imágenes e Imagineros: representaciones de los indígenas ecuatorianos Siglos XIX y XX (pp. 9-24). 1 a edición, FLACSO-Sede Ecuador.

- (1994). Nación, Identidad, y Etnicidad: Imágenes de los Indios Ecuatorianos y sus imagineros a fines del Siglo XIX. En Blanca Muratorio (Ed.), Imágenes e Imagineros: representaciones de los indígenas ecuatorianos Siglos XIX y XX (pp. 109). 1 a edición, FLACSO-Sede Ecuador.

Paladines, Fernando. (2012). Sistema Exner para Rorschach. Manual práctico de aplicación y codificación. Quito-Ecuador, Abya-Yala.

Palma, Hector. (2005). Consideraciones historiográficas, epistemológicas y prácticas de la eugenesia. En: Darwinismo social y eugenesia en el mundo latino, Marisa Miranda y Gustavo Vallejo (ed.), - 1 a ed.- Buenos Aires. Siglo XXI de Argentina Editores.

Polo, Rafael. (2002). Los intelectuales y la narrativa mestiza en el Ecuador. Quito, AbyaYala, Serie Magister volumen 23, Universidad Andina Simón Bolívar.

- (Agosto2009). Ciudadanía biopoder (las sugerencias de Andrés Guerrero). Revista Ecuador Debate N. 77. Quito-Ecuador. . (2010). Campo de visibilidad y producción de narrativas. En: Mancero Mónica, Polo Rafael (Comp.), Debates contemporáneos desde Ecuador, cuadernos de trabajo, Quito, FLACSO-CONESUP, Pp. 17-45.

Prieto, Mercedes. (2010). Indigenismo: la red interamericana. En: Ecuador y México: Vinculo histórico e inter-cultural (1820-1970). Quito, Museo de la Ciudad (ed). . (2015). Estado y colonialidad: Mujeres y familias quichuas de la Sierra del Ecuador, 1925-1975. Quito, FLACSO Ecuador. 
Radcliffe, Sarah A. y Westwood, Sallie. (1999). Rehaciendo la nación: lugar, identidad y política en América Latina. Quito, Ediciones ABYA-YALA.

Ricoeur, Paúl. (2004). La historia, la memoria, el olvido. Buenos Aires: Fondo de Cultura Económica.

Robles, Francisco, y Caballero, Vicente. (21 de octubre 2016). La eugenesia de la hispanidad de Vallejo Nágera y su introducción en Latinoamérica. Revista de Historia de las ideas políticas. Recuperado de https://revistas.ucm.es/index.php/RPUB/article/viewFile/54996/50116

Rodas, Germán, Ricardo Paredes. (2011). El médico que se formó bajo la huella de la Revolución juliana. Quito: Colección popular 15 de noviembre.

Rodríguez, Juan (s.f.). Julio Endara, del positivismo al Rorschach. Biblioteca SAAVEDRA FAJARDO de Pensamiento Político Hispánico. Recuperado de http://www.saavedrafajardo.org/archivos/endararorschach.pdf

Rufer Mario. (2010b). La nación en escenas: memoria pública y usos del pasado en contextos coloniales - 1 a ed. - México, D.F.: El Colegio de México, Centro de Estudios de Asia y África.

- (2010a). La temporalidad como política: nación, formas de pasado y perspectivas poscoloniales. Memoria y Sociedad 14, no. pp 11-31. Recuperado de http://www.scielo.org.co/pdf/meso/v14n28/v14n28a02.pdf

. (3 de septiembre - diciembre 2004). Encantos perdurables, ordenamientos persistentes (o genealogías de la modernidad): reflexiones en torno de un debate. Estudios de Asia y África, vol. XXXIX, núm. 3. El colegio de México, A.C. Distrito Federal, México. $\quad$ Recuperado https:/www.jstor.org/stable/40313568?seq=1\#page scan tab contents

(jan-jun 2011). La memoria de los otros: Subalternidad, poscolonialismo y regímenes de verdad. REALIS. Revista de Estudios AntiUtilitaristas e PosColoniales.Vol. 1, $\mathrm{n} \quad 01 . \quad$ Recuperado de https:/www.researchgate.net/publication/266460780_LA_MEMORIA_DE_LOS_OTROS _Subalternidad_poscolonialismo_y_regimenes_de_verdad 
Sánchez, Ménthor. (2005). Poder y locura: una investigación y estudio sociológico de la locura en el Hospital Psiquiátrico San Lázaro, Quito, Espín Graf.

Segato, Rita. (2007). La Nación y sus Otros. Raza, etnicidad y diversidad religiosa en tiempos de políticas de la identidad $-1^{\mathrm{a}}$ ed.- Buenos Aires: Prometeo libros.

Serrano Herbozo. (2016). Paulette Milena, Salud Pública y Eugenesia: El control Gubernamental del cuerpo de las prostitutas en Quito (1900-1940). Disertación previa a la obtención del título de Historiadora, PUCE, Quito, Ecuador. Recuperada de http://repositorio.puce.edu.ec/handle/22000/13239

Sevilla, Ana y Sevilla Elisa (2016). Ángeles caídos o animales perfectibles: el darwinismo en las disputas entre liberales y conservadores en el Ecuador (1875 - 1895). En: Evolucionismo en América y Europa, Antropología, Biología, Política y Educación, Nicolás Cuvi, Elisa Sevilla, Rosaura Ruiz y Miguel Ángel Puig-Samper (Editores). FLACSO Sede Ecuador, UNAM, PUCE, Ediciones Doce Calles.

Stolcke, Varena. (2000). ¿Es el sexo para el género lo que la raza para la etnicidad... Y la naturaleza para la sociedad?. Política y Cultura, n 014. Recuperado de http://sgpwe.izt.uam.mx/files/users/uami/ana/StolckeGeneroEtnicidad.pdf

. (julio 2009). Los mestizos no nacen sino que se hacen. AVÁ, Revista de Antropología, n. 14. Recuperado de http://www.redalyc.org/articulo.oa?id=169013838002 . (2011). Presentación Simposio Internacional ¿Naturaleza o Cutura? Un debate necesario. Dialnet, $n$ 27. Recuperado de https://www.raco.cat/index.php/QuadernsICA/article/view/258366/351464

Suárez, Laura y Guazo, López (2016). Eugenesia en México: De la selección matrimonial a los consultorios de Salud Hereditaria. En: Evolucionismo en América y Europa, Antropología, Biología, Política y Educación, Nicolás Cuvi, Elisa Sevilla, Rosaura Ruiz y Miguel Ángel Puig-Samper (Editores). FLACSO Sede Ecuador, UNAM, PUCE, Ediciones Doce Calles. 
Osorio, Andrés. (2014). El juicio final: contribución para una lectura del nacimiento de la psiquiatría en el Ecuador, tesis previa a la obtención de la maestría en Ciencias Sociales con mención en Sociología. Quito: FLACSO- Sede Ecuador.

Ospina, Pablo. (1996). Imaginarios nacionalistas. Historia y significados nacionales en Ecuador, siglos XIX y XX. Procesos. Revista Ecuatoriana de Historia. No. 9. Quito: TEHIS.

Orbegoso, Arturo. (2012). Eugenesia, Tests mentales y Degradación racial en el Perú. Universidad César Vallejo y Universidad Privada del Norte. Recuperado de file://C:/Users/User/Downloads/198-\%23\%23default.genres.article\%23\%23-524-2-1020171130.pdf

Sánchez, Ménthor. (2005). Poder y locura: una investigación y estudio sociológico de la locura en el Hospital Psiquiátrico San Lázaro, Quito, Espín Graf.

Sánchez, Paola. (junio 2011). Ciudadanía, meritocracía y descorporativización. Revista malaidea No 1. Quito-Ecuador.

Vallejo, Gustavo. (2016). Eugenesia, cultura científica y cultura política. Apuntes para repensar una relación incómoda. Argentina (1900-1939). En: Evolucionismo en América y Europa, Antropología, Biología, Política y Educación, Nicolás Cuvi, Elisa Sevilla, Rosaura Ruiz y Miguel Ángel Puig-Samper (Editores). FLACSO Sede Ecuador, UNAM, PUCE, Ediciones Doce Calles.

Vallejo, Gustavo; Miranda, Marisa. (2005). La eugenesia y sus espacios institucionales en Argentina. En: Darwinismo social y eugenesia en el mundo latino, Marisa Miranda y Gustavo Vallejo (ed.), - 1 a ed.- Buenos Aires. Siglo XXI de Argentina Editores.

Ventura, Montserrat. (marzo 2011). Un diálogo con Varena Stolcke: La naturaleza y la cultura no son dos extremos de un continuum. Iconos, Revista de Ciencias Sociales, n 40. Recuperado de http://www.flacso.org.ec/docs/i40ventura.pdf

Visacovsky, Sergio, "El temor a escribir sobre historias sagradas", Fréderic, Sabina y Germán Soprano (comps), Cultura y Política en Etnografias sobre la Argentina. 
Universidad Nacional de Quilmes, Provincia de Buenos Aires, Argentina, 2005, pp. 271313.

, Historias próximas historias lejanas. Usos sociales de las distancias temporales en la organización de las experiencias sobre el pasado: El caso del servicio de psiquiatría del Lanús. En: Historia reciente, desafíos para un campo en construcción, Marina Franco y Florencia Levín (Comp.). (2007).

Yzú Rossini, Brunella. (2016). La eugenesia peruana a partir de la obra de Carlos Enrique Paz Soldán (1900-1965). Tesis para la optar el título de Licenciada en Humanidades con mención en Historia, PUCP Facultad de Letras y Ciencias Humanas, Lima, Perú. Recuperada

de file:///C:/Users/User/Downloads/YZU_ROSSINI_BRUNELLA_EUGENESIA_PERUAN $\underline{\mathrm{A} \% 20(1) . p d f}$

\section{Fuentes escritas}

Asociación Latinoamericana Pro Salud Mental. (1958). Tercer Congreso Latino-americano de Salud Mental, Acta final. Archivos de Criminología. 2 da. época, Vol. 6, No. 24, octubre-diciembre, Quito, Casa de la Cultura Ecuatoriana, pp. 600-609.

Engel, Paúl. (1956). El Centenario de Sigmund Freud. Archivos de Criminología. 2 da. época, Vol. 4 , No. 14, abril-junio, Quito, Casa de la Cultura Ecuatoriana, pp. 467-478.

Fournié, Emilio. (1955). Abismos Humanos [Revisión del libro Abismos Humanos del Dr. Agustín Cueva Tamariz]. Archivos de Criminología. 2 da. época, Vol. 3, No. 9, eneromarzo, Quito, Casa de la Cultura Ecuatoriana, pp. 139-140.

Canelos, P., y Cevallos, R. T. (1967). Manifestaciones Psicológicas y Psiquiátricas del alcoholismo crónico en la población indígena. Archivos de Criminología. 2 da. época, Vol. 15, No. 57-58, enero-junio, Quito, Casa de la Cultura Ecuatoriana, pp. 92-115. 
Correa, Alberto. (1930). La construcción del nuevo manicomio. Boletín del Hospital Civil de San Juan de Dios. Año V, Enero-Junio, Quito-Ecuador, Impreso por Manuel Piedra, pp. $36-41$.

Cruz Cueva, José. (1953). Estado Mental y Capacidad Civil. Archivos de Criminología, 2 da. época, Vol. 1, No 2, abril-junio, 1953, Quito, Casa de la Cultura Ecuatoriana, pp. 214226.

. (1954). Higiene Mental y vicios Sociales. Archivos de Criminología. 2 da. época, Vol. , No. 8, octubre-diciembre, Quito, Casa de la Cultura Ecuatoriana, pp. 467478.

- (1955). Higiene Mental del Empleado Público. Archivos de

Criminología. 2 da. época, Vol. 3 , No. 12, octubre-diciembre, Quito, Casa de la Cultura Ecuatoriana, pp. 583-599.

Cueva Tamariz, Agustín. (1954). Hacia una Biotipología Indígena. Archivos de Criminología. 2 da. época, Vol. 2, No. 5, enero-marzo, Quito, Casa de la Cultura Ecuatoriana, pp. 111-121.

. (1954). E. Kretschmer: Constitución y carácter. Archivos de Criminología, 2 da. época, Vol. 2, No 6, abril- junio, 1954. Quito, Casas de la Cultura Ecuatoriana.

- (1954). Dr. Julio Endara: Psicodiagnóstico de Rorschach [Revisión del libro Psicodiagnóstico de Rorschach. Técnica general. Aplicaciones clínicas. Investigaciones de Clínica Psicológica, por Dr. Julio Endara]. Archivos de Criminología. 2 da. época, Vol. 2, No. 7, julio-septiembre, Quito, Casa de la Cultura Ecuatoriana, pp. 427429.

. (1954). Simón Rodríguez: ¿Genio o Locura? - (Nota para el Dr. Oliver Brachfeld), Archivos de Criminología, neuropsiquiatría y disciplinas conexas, 2 da. época, Vol. 2, No 6, abril- junio, Casa de la Cultura Ecuatoriana. 
. (1956). Los disidentes de Freud. Archivos de Criminología. 2 da. época, Vol. 4 , No. 14, abril-junio, Quito, Casa de la Cultura Ecuatoriana, pp. 467-478.

Dalma, Juan. (1958). Utilidad y posibilidad de un Censo Psíquico integral de la población su importancia en las investigaciones de Salud Mental. Archivos de Criminología. 2 da. época, Vol. 6, No. 24, octubre-diciembre, Quito, Casa de la Cultura Ecuatoriana, pp. 553570.

Endara, Julio. (1937). La Historia de Clínica Criminológica. Archivos de Criminología, Vol. 1, N. 1, 3 y 4, febrero-abril, Quito, Ministerio de Gobierno, Justicia y Cárceles, pp. 139-179.

. (1937). Criminología, Derecho Penal, Sociología [Revisión del libro Indoamericanismo y Raza India, por Prof. A. Lipschutz]. Archivos de Criminología, Vol. 1, N. 7 a 12, julio-diciembre, Quito, Ministerio de Gobierno, Justicia y Cárceles, pp. 406.

- (1937). Clasificación de las enfermedades mentales y posibilidad de uniformarlas en Sudamérica, Archivos de Criminología.

. (1953). Psicodiagnóstico de Rorschach y Raza. Archivos de Criminología, 2da época, Vol. 1, N. 1, enero-marzo, Quito, Casa de la cultura Ecuatoriana, pp. 41-66.

. (1954). Aniversario del Prof. E. Kretschmer. Archivos de Criminología, 2 da. época, Vol. 2, No 6, abril- junio, Quito, Casas de la Cultura Ecuatoriana.

. (1959). Degradaciones y Desvitalizaciones en los delincuentes a través del Test de Rorschach. Archivos de Criminología. 2 da. época, Vol. 7, No. 26, abril-junio, Quito, Casa de la Cultura Ecuatoriana, pp. 167-181.

. (1961). Proyecto de Ley de Salud Mental. Archivos de Criminología. 2 da. época, Vol. 9, No. 34, abril-junio, Quito, Casa de la Cultura Ecuatoriana, pp. 223-244.

Garcés, Enrique. (1953). Necesidad de una psicología del padecer de los pueblos. Archivos de Criminología, 2 da. época, Vol. 1, No 2, abril-junio, Quito, Casas de la Cultura Ecuatoriana, pp. 193-198. 
- (1961). Grandeza, Servidumbre y Resentimiento. Archivos de Criminología. 2 da. época, Vol. 9, No. 36, octubre-diciembre, Quito, Casa de la Cultura Ecuatoriana, pp. 665-676.

Godoy B., Genoveba. (1956). Formas predominantes de la Criminalidad en Latinoamérica. Archivos de Criminología. 2 da. época, Vol. 4, No. 13, enero-marzo, Quito, Casa de la Cultura Ecuatoriana, pp. 56-69.

Mariátegui, Javier. (1965). Eugenesia y Psiquiatría: Alcance del concepto de Eugenesia en Psiquiatría. Archivos de Criminología. 2 da. época, Vol. 13, No. 50, abril-junio, Quito, Casa de la Cultura Ecuatoriana, pp. 152-173.

Safadi, Fortunato. (1961). Organización de la Higiene Mental en el Ecuador. Archivos de Criminología. 2 da. época, Vol. 9, No. 34, abril-junio, Quito, Casa de la Cultura Ecuatoriana, pp. 245-254.

Sole, Sagarra. (1955). Resumen de Eugenesia psiquiátrica. Archivos de Criminología. 2 da. época, Vol. 3, No. 10, abril-junio, Quito, Casa de la Cultura Ecuatoriana, pp. 209-221.

Vallejo Nagera, Antonio. (1953). Evolución Histórica de las Ideas Psiquiátricas Hispanas, Archivos de Criminología, 2 da. época, Vol. 1, No 1, enero- marzo, Quito, Casas de la Cultura Ecuatoriana, pp. 67-87. 